\title{
INTEGRACIÓN REGIONAL Y COMUNIDADES DE SEGURIDAD: UNA PERSPECTIVA DESDE AMÉRICA DEL SUR
}

\author{
Por \\ JORGE RIQUELME RIVERA \\ TRABAJO DE INVESTIGACIÓN PARA OPTAR AL GRADO ACADÉMICO DE \\ DOCTOR EN RELACIONES INTERNACIONALES
}

UNIVERSIDAD NACIONAL DE LA PLATA 
Desde luego, para Florencia Ignacia. Por todas las razones del mundo. 
"...bajo los tumultos no hay nada. No es otra cosa que apariencia, que una superficie de imágenes; por eso mismo puede acaso agradar"

Historia Universal de la Infamia. Jorge Luis Borges 


\section{ÍNDICE}

1.- Introducción.

2.- La relación entre integración regional y seguridad. Una perspectiva teórica sobre las

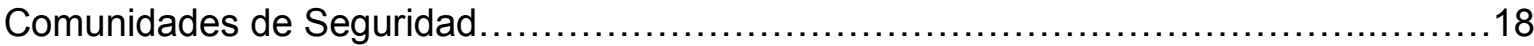

3.- El escenario internacional contemporáneo y el lugar de América Latina..................36

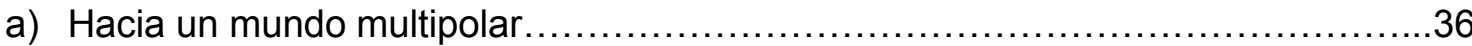

b) Multipolarismo e integración regional. Una perspectiva desde América

Latina.

4.- El contexto regional: democracia y paz en América del Sur

a) América del Sur como Zona de Paz, una mirada histórica.......................64

b) El predominio de la democracia en América del Sur.................................68

c) Una mirada desde las relaciones civil-militares. Sus efectos en la paz regional.

5.- Integración y seguridad en América del Sur. Los antecedentes regionales y subregionales del Consejo de Defensa

Suramericano

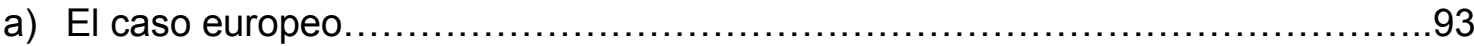

b) El esquema hemisférico de seguridad y defensa............................... 102

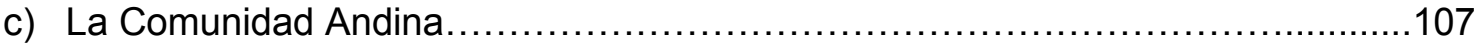

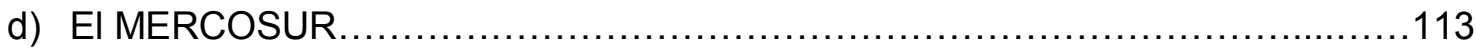

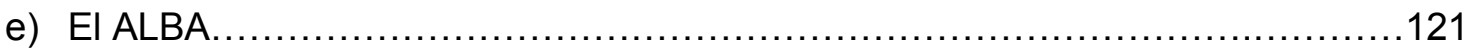

6.- El establecimiento y desarrollo del Consejo de Defensa Suramericano como expresión

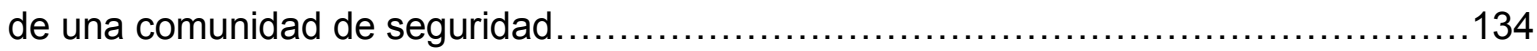

a) La UNASUR y el Consejo de Defensa Suramericano...........................134

b) Temas relevantes en la agenda del Consejo de Defensa

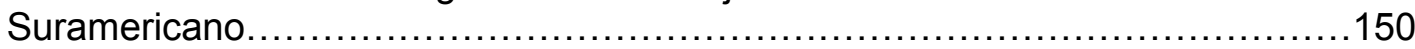

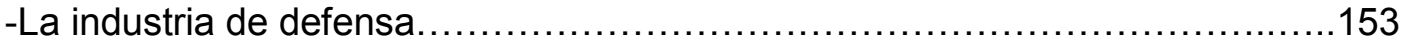

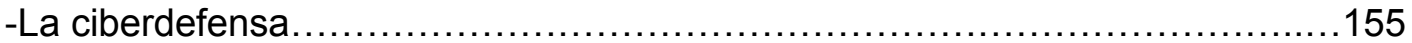

- Hacia un pensamiento estratégico regional: El Centro de Estudios Estratégicos de Defensa (CEED) y la Escuela Suramericana de Defensa (ESUDE) 158

c) ¿Hacia una estructura institucional más densa? 166 
d) La participación en el Consejo de Defensa Suramericano y las políticas exteriores

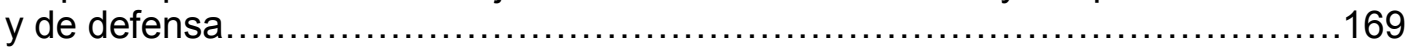

7.- El papel de los liderazgos en la constitución del Consejo de Defensa

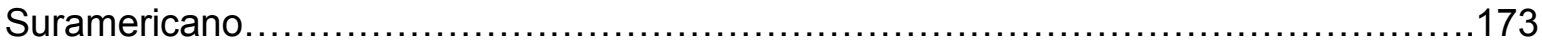

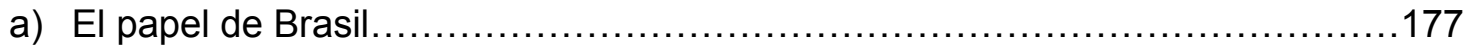

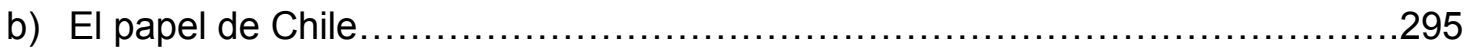

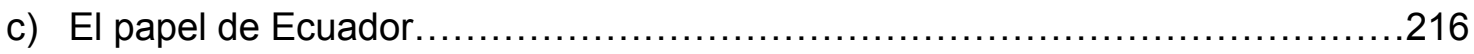

d) Un liderazgo emergente en el Consejo de Defensa Suramericano. El caso de

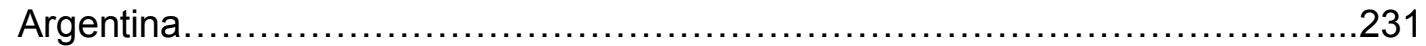

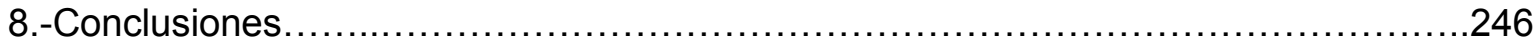

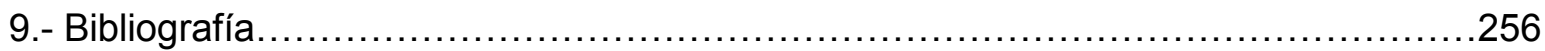




\title{
1.- Introducción
}

El término del siglo $X X$ estuvo marcado por profundos cambios en la política y la economía globales, que dieron un impulso notable al régimen democrático de gobierno y al libre mercado. El fin de la Guerra Fría implicó, entre otros hechos, el surgimiento de un escenario internacional que poco tiene que ver con el sistema que se conoció en el mundo desde el término de la Segunda Guerra Mundial y, sobre todo, con el orden político interestatal surgido a partir de la Paz de Westfalia de 1648. En los hechos, el contexto mundial que se comenzó a configurar desde fines de los ochenta está marcado por una continua mutabilidad e incertidumbre, avanzando con contradicciones y tropiezos hacia la desconcentración y multipolaridad del poder mundial. Como señala el profesor Celestino del Arenal:

\begin{abstract}
"El sistema internacional no es ya un sistema exclusivamente estatocéntrico, sino un sistema cada vez más multicéntrico a nivel de actores $y$, consecuentemente, más imprevisible a nivel de estructuras y dinámicas, en el que el reparto del poder no se circunscribe sólo a Estados, ni se realiza en los términos tradicionales establecidos por el realismo" (Del Arenal, 1993: 79$80)$.
\end{abstract}

Con todos los conflictos y crisis periféricas, que marcaron a generaciones a lo largo y ancho del orbe, la Guerra Fría se transformó en un modo de vida que dotó de cierta estabilidad al mundo, cuestión que mutó rápidamente con la llegada de la década de los noventa. Según plantea el profesor Del Arenal, la relativa simplicidad que presentaba el mundo estatocéntrico de los siglos anteriores y más en concreto, el mundo posterior a la Segunda Guerra Mundial, caracterizado por una bipolaridad en el plano estratégico-militar y por la hegemonía económica de Estados Unidos, ha dado paso a un "mundo de complejidad, movilidad e incertidumbres crecientes" (Del Arenal, 1993: 80). Se está en presencia de un contexto marcado por la volatilidad y la complejidad, un "tiempo líquido", en los términos sugeridos por Zygmunt Bauman (2007), que desde el arte a las ciencias 
naturales, pasando por el ámbito militar, experimentaría variados cambios, con las consecuentes crisis de paradigmas.

Incluso en la Academia de Guerra del Ejército de los Estados Unidos, ante el escenario cada vez más complejo que se comenzó a estructurar desde la década de los noventa, se definió el acrónimo VUCA, dando cuenta de un escenario global marcado por la volatilidad, incertidumbre (uncertainty), complejidad y ambigüedad. Es decir, un nuevo sistema internacional con diversos subsistemas y componentes, con una densa e indefinida red de interacciones, cuyas únicas características constantes son su multiplicidad, diversidad e interdependencia. Su carácter esencialmente complejo derivaba de las dificultades de establecer cualquier tipo de predicciones (véase Yarger, 2006).

En el ámbito de las instituciones multilaterales relacionadas con la seguridad internacional, este nuevo escenario global supondría el replanteamiento de los mecanismos regionales de corte defensivo, propios de la Guerra Fría, como fue el caso de la Alianza Atlántica en el contexto europeo, así como la desaparición del Pacto de Varsovia en 1991. Igualmente, la política internacional sería testigo de la proliferación de crisis del Estado, ${ }^{1}$ enfrentadas desde la comunidad de naciones mediante las cada vez más numerosas operaciones de mantenimiento de la paz, que muchas veces darían cuenta de las limitaciones de las actividades implementadas por las Naciones Unidas, lo que atizaría los debates sobre su reforma (Sepúlveda, 1995).

En tal contexto, los Estados-nación tradicionales han requerido de nuevos conceptos y marcos teóricos para el análisis de su entorno regional y global, por cuanto es claro que las primeras aproximaciones optimistas sobre la realidad mundial, como la teoría del "Fin de la Historia" planteada por Francis Fukuyama (1990), han perdido terreno frente a otras interpretaciones pesimistas, que ponen el acento en las tendencias conflictivas del escenario internacional contemporáneo. Los escenarios de Medio Oriente, la península de Corea y Eurasia parecerían darle la razón a estas últimas interpretaciones, particularmente con el desarrollo que evidencia el terrorismo internacional con el accionar del

\footnotetext{
${ }^{1}$ Un interesante análisis sobre la crisis del Estado y sus efectos en la "gobernanza" global, puede verse en Williams (2016).
} 
Estado Islámico, el desarrollo de armas de destrucción masiva y el caso de Ucrania, que podría interpretarse como una vuelta a la Guerra Fría, con una Rusia en declive económico y demográfico, que presiona por recuperar su perdido status de superpotencia.

Según Fukuyama, siguiendo el razonamiento de Hegel expuesto en el libro Fenomenología del espíritu, el colapso del bloque soviético significó el triunfo de la democracia liberal en el mundo, como la mejor forma de organización política que los hombres habrían podido concebir. Se terminaba la historia como proyecto, porque terminaba la lucha dialéctica entre distintos sistemas de ideas y de gobierno. Luego del fin de la Guerra Fría, unos antes u otros después, los países paulatinamente se convertirían a la democracia de perfil anglosajón, como parte de un proceso que desde la politología se denominó como la "Tercera ola democrática" (Huntington, 1994). Según el Índice de la Democracia 2016 de The Economist, casi la mitad de los países del mundo vive en democracias. ${ }^{2}$

En la arena política, la democracia proveería elecciones y resguardaría los derechos constitucionales de los ciudadanos; mientras en el terreno económico protegería la propiedad y permitiría la creación de riqueza, bajo un sistema de corte capitalista. Según Fukuyama, ningún otro sistema o ideología proveería de mejor manera tales beneficios, fomentando sociedades prósperas y estables (véase Binnendijk y Kugler, 2006: 19). De esta manera, el creciente predominio de la democracia en el mundo redundaría en un escenario internacional cada vez más pacífico. Como planteara Michael Doyle en 1983, habría una cierta correspondencia entre la política interna y la prevención de los conflictos armados, en tanto los países democráticos no irían a la guerra entre sí, bajo el concepto de la "paz democrática" (Doyle, 1983), lo que no obstaría que los países con este régimen político manifiesten un fuerte belicismo hacia aquellos no liberales -como lo ilustra la dilatada proyección exterior de Estados Unidos- teoría que tiene un cierto sustento histórico.

No obstante, los genocidios de Bosnia, Kosovo, Ruanda y Darfur echaron por tierra las visiones optimistas sobre el nuevo panorama mundial, al tiempo que

${ }^{2}$ El Índice de la Democracia se encuentra disponible en https://www.eiu.com/topic/democracy-index Recuperado en octubre de 2017. 
demostraban la inutilidad de las fuerzas armadas tradicionales y la inoperancia de los mecanismos internacionales de resolución de conflictos, particularmente del Consejo de Seguridad de Naciones Unidas. Con el fin del conflicto bipolar ya no tenía sentido reflexionar sobre el conflicto en el clásico sentido interestatal.

Los nuevos escenarios involucran luchas motivadas por problemas étnicos y religiosos de carácter intraestatal. Gran parte de los conflictos actuales forman parte de las denominadas guerras no convencionales o asimétricas, muchas de las cuales involucran campañas de contrainsurgencia, antiterrorismo, ciberseguridad o intervenciones de carácter humanitario, todas las cuales han supuesto un profundo cambio de paradigma en la manera de entender el tradicional conflicto bélico. Las nuevas formas de la guerra involucran, asimismo, estrategias en los variados ámbitos de la vida social. Tal es el caso de la denominada Guerra Irrestricta, ideada por los militares chinos Qiao Liang y Wang Xiangsui, según los cuales la primera regla del conflicto es que no hay reglas. Bajo este concepto, la guerra desborda los tradicionales métodos y campo de batalla, buscando explotar las diversas áreas de vulnerabilidad del oponente, en el plano cultural, económico, financiero, ambiental, tecnológico y mediático, entre otros (Liang y Xiangsui, 2002).

Dando cuenta de esta profunda transformación, el general británico Rupert Smith, ha señalado que se asiste a la transición desde la "guerra industrial", protagonizada por fuerzas armadas nacionales, cuya finalidad era quebrar la voluntad del adversario en un campo de batalla definido, con el objeto de alcanzar la victoria, hacia un nuevo paradigma definido por la denominada "guerra en medio de la población", frecuentemente protagonizada por fuerzas irregulares, donde el objetivo es modificar las intenciones o captar la voluntad, no sólo del adversario, sino también de la población que queda en medio de las operaciones (Smith, 2006). En esta nueva versión de la guerra, que borra las clásicas distinciones entre lo civil y lo militar, no sólo es relevante la capacidad bélica y la voluntad de lucha, sino mucho más, la capacidad de ganar local e internacionalmente el apoyo político de la población y los gobiernos hacia una causa apreciada como legítima y justa. 
Junto a lo antes expuesto, los atentados terroristas perpetrados sobre Nueva York y Washington D.C. el 11 de septiembre de 2001 daban cuenta de un contexto global marcado por la desterritorialización de la violencia y una acentuada securitización de la agenda internacional. Esta situación ha cobrado nueva trascendencia con la actividad terrorista puesta en práctica por el Estado Islámico en Medio Oriente y, sobre todo, en Europa.

Todo lo anterior, sin olvidar que todavía en el mundo persisten conflictos de carácter tradicional e interestatal, como lo demuestra el delicado entrecruzamiento de diversos dilemas de seguridad en Asia y Medio Oriente, como es el caso del inestable y complejo escenario de las dos Coreas, Japón y China, China y Rusia, Pakistán e India, India y China, así como entre diversos países de Medio Oriente, por mencionar algunos de ellos (Tokatlián, 2012: 98). Por lo demás, muchos de estos han sido atizados con el despliegue exterior de Estados Unidos, bajo la conducción del Presidente Donald Trump, que se ha expresado en dos tendencias que a primera vista parecen incongruentes: el aislacionismo por un lado, o el intervencionismo o policía mundial, por el otro. Ello, de la mano de una fuerte crítica al multilateralismo y al Derecho Internacional, que ha tenido su expresión más notoria en la decisión del gobierno norteamericano de trasladar su Embajada en Israel desde Tel Aviv a Jerusalén.

Un autor cercano a las ideas neoclásicas sobre las Relaciones Internacionales, como Moisés Naím, señala que las guerras actualmente son cada vez más asimétricas, con el enfrentamiento de grandes fuerzas militares contra otras más pequeñas y heterodoxas: rebeldes, movimientos separatistas, grupos insurgentes o milicias, entre otros. Además, es cada vez más frecuente que gane el bando que posee un menor poder militar, en tanto mantiene la capacidad de infligir daños al adversario con un coste inferior (Naím, 2013: 23). A ello se agrega el enorme impacto de los nuevos conflictos sobre la población civil (Ambrose, 1997).

En suma, se asiste a una democratización de los medios y una transformación radical de la guerra en su sentido más tradicional, lo que resulta especialmente evidente en el caso del ciberespacio. $Y$ como señala Naím, todas estas transformaciones han conllevado a una profunda reflexión en los Ministerios de Defensa y en las academias militares, respecto a la manera de enfrentar este 
amplio abanico de desafíos, por cuanto "Hoy en día, las guerras irregulares y asimétricas se han convertido en habituales" (Naím, 2013: 172).

Todo lo anterior ha estado contextualizado en un mundo que paulatinamente avanza hacia el multipolarismo, mediante el desarrollo de nuevos centros de poder político y económico. Zbigniew Brzezinski ha denominado a esta nueva etapa de la política mundial como una "era posthegemónica", donde "ninguna nación tiene la capacidad de imponer su voluntad a las demás de forma permanente ni sustancial" (En Naím, 2013: 197). Coincidiendo en cierta manera con este argumento, el profesor de la Universidad de Georgetown, Charles Kupchan, ha definido al mundo del siglo XXI como el mundo de nadie (Kupchan, 2012).

En este marco general, para los países pequeños, la posibilidad de incidir en la toma de decisiones sobre los grandes sucesos de la política mundial radica en la capacidad de actuar de manera concertada y colectiva. Sólo actuando en bloque, a través de instancias de concertación e integración regional, los países de la tradicionalmente denominada periferia pueden incidir en los grandes temas actuales, incrementando su poder relativo y sus atributos de soberanía. En tal sentido, como se explicará más adelante, la integración en un sentido puede apreciarse como un mecanismo en el cual los países ceden soberanía en favor de la nueva comunidad política pero, desde otro enfoque, puede igualmente sostenerse que actuando en bloque los Estados ganan soberanía en el plano global, favoreciendo sus propios atributos y capacidad de influencia.

En consecuencia, para los efectos de este trabajo, se entenderá que la complejidad de los temas que deben enfrentar los países a partir del fin de la Guerra Fría, conjuntamente con el dinamismo que exhibe el proceso de globalización, ha implicado una tendencia creciente hacia el desarrollo y proliferación de mecanismos de integración regional en el mundo, con efectos trascendentes sobre el concepto tradicional de la soberanía y la seguridad y, en consecuencia, en el plano de la defensa. La interdependencia entre los miembros de la sociedad internacional ha resultado en ciertas dificultades para los actores estatales y no estatales para actuar individualmente frente al amplio espectro de demandas, desafíos y amenazas que lleva aparejado el proceso de globalización, particularmente en las temáticas relacionadas con lo estratégico-militar. 
El contexto internacional contemporáneo supone una ampliación y un cambio en los tipos de conflicto y en las tradicionales amenazas y retos que deben enfrentar los Estados, los que consecuentemente deben actualizar y hacer coherentes con este escenario sus respectivos mecanismos de respuesta. A los clásicos desafíos militares se han unido nuevas amenazas relacionadas con el subdesarrollo y la marginalidad, los ilícitos transnacionales, el terrorismo, las ciberamenazas, la degradación del medio ambiente y los desastres naturales, así como las violaciones sistemáticas sobre los derechos humanos, entre muchos otros. Mario Laborie, del Instituto Español de Estudios Estratégicos, coincide con lo anterior, señalando que:

"Tras el fin de la Guerra Fría y como consecuencia de la globalización, las amenazas dejan de poseer un carácter puramente militar, ampliándose el concepto de seguridad. Problemas globales, transfronterizos en su mayoría, tales como el crimen organizado, el terrorismo, la degradación del medio ambiente, la disputa por los recursos naturales, los flujos incontrolados de refugiados, la inmigración no regulada, la pobreza y el hambre se han convertido en riesgos para la humanidad de una importancia similar a la de la tradicional defensa militar" (Laborie, 2011: 2).

Este entorno internacional, cada vez más complejo, vuelve difusa la otrora perceptible distinción entre aquellos retos y amenazas internos y externos, o entre asuntos civiles y militares, volviendo la separación entre seguridad y defensa un tema cada vez más cuestionable. En tal marco global las opciones autárquicas y puramente militares resultan poco apropiadas y eficaces. La seguridad de los países ya no puede asumirse unilateralmente ni descansar exclusivamente en la disuasión, la acumulación de armamentos y a expensas de los vecinos. Como parte de la interdependencia, la seguridad ya no es un juego de suma cero $y$, en consecuencia, la defensa debe asumirse bajo una perspectiva cooperativa, donde 
en la medida que un actor gana en seguridad, estos avances favorecen a todo el colectivo.

Es decir, para satisfacer sus cada vez más variadas necesidades en este plano, los Estados requieren de ámbitos de acción más amplios, donde se supone una acción regional cooperativa entre países con homogeneidades políticas, económicas y culturales. En suma, mediante acciones en el campo de la seguridad cooperativa, los Estados favorecen un ambiente securitario que favorece a la región en su conjunto.

En el ámbito hemisférico, el sistema interamericano orquestado por la Organización de Estados Americanos (OEA), creada en Bogotá en 1948, la Junta Interamericana de Defensa (JID), que data de 1942 (en marzo del año 2006 esta entidad fue incorporada a la OEA, estando entre sus funciones el asesoramiento técnico y consultivo en materias relacionadas con los asuntos militares y de defensa a los miembros de dicha organización), así como por el Tratado Interamericano de Asistencia Recíproca (TIAR), de 1947 -a los que se puede agregar, a partir de 1994, la Conferencia de Ministros de Defensa de las Américas (CMDA)-, está marcado por las variadas críticas acerca de su obsolescencia y poca operatividad. La erosión y descrédito del sistema se comenzó a plantear con fuerza desde mediados de la década de los ochenta, de manera paralela con los procesos de transición democrática vividos en América Latina en ese entonces. Estas impugnaciones siguen plenamente vigentes y forman parte importante de los debates hemisféricos en el plano de los asuntos políticos y estratégicos.

La crítica principal se refiere a que dicha arquitectura responde a un escenario internacional propio de la Guerra Fría, con un predominio de los intereses de Estados Unidos, por sobre los de la región de América Latina. El hecho principal que pondría de manifiesto la inoperancia del sistema interamericano fue la Guerra de las Malvinas, donde el TIAR fue bloqueado por la potencia norteamericana, mientras otros países del hemisferio actuaron en apoyo del Reino Unido. De hecho, es justo señalar también que, para el mismo Estados Unidos en la actualidad, las prioridades de seguridad no están en el continente americano, sino en escenarios más lejanos, como es el caso de Medio Oriente, Eurasia y Corea del Norte (véase Da Silva, 2012). 
Sin embargo, la obsolescencia y debilidad de los mecanismos hemisféricos no ha sido óbice para la subregionalización de los mecanismos de seguridad y defensa, como lo expresan los diversos instrumentos adoptados a nivel del Cono Sur, el área andina y América del Sur, como son las declaraciones de Zonas de Paz y una serie de mecanismos bilaterales y multilaterales de cooperación en defensa.

En este orden de ideas, ya en 2007 el analista político Pablo Celi sostenía que el escenario continental está marcado por intensas críticas sobre la OEA, la práctica inexistencia de un sistema de seguridad hemisférico, la ausencia de un mecanismo multilateral efectivo de manejo de conflictos y una creciente tendencia a la subregionalización de los esquemas de seguridad (Celi, 2007). En el ámbito de América del Sur, esta última situación ha sido particularmente manifiesta con el desarrollo que expresa la Unión de Naciones Suramericanas (UNASUR) y, en su seno, el Consejo sectorial encargado de la coordinación y cooperación en el terreno defensivo, o sea, el Consejo de Defensa Suramericano (CDS). Es cierto que últimamente la UNASUR está pasando por una crisis, derivada de las dificultades de consensuar un Secretario General, situación que llevó a los gobiernos de Argentina, Brasil, Colombia, Chile, Paraguay y Perú, en abril de 2018, a decidir no participar en las distintas instancias de este esquema, hasta que se aprecien "resultados concretos que garanticen el funcionamiento adecuado de la organización". No obstante, se trata de críticas metodológicas sobre la integración, es decir, no cuestionan el porqué trabajar juntos, sino giran en torno al cómo. Todavía la integración es un objetivos que persiguen, si bien con distintos énfasis, los países de la región.

La presente investigación plantea que América del Sur puede considerarse como una Zona de Paz, donde la posibilidad de conflicto interestatal es escasa, aunque en el plano transnacional, la presencia del crimen organizado, particularmente el vinculado con el narcotráfico, es evidente. En este marco regional, el CDS surgió en 2008 bajo el fuerte impulso de Brasil (Comini, 2015), con el objetivo de consolidar a América del Sur como una Zona de Paz, construir una identidad regional en materia de defensa y producir consensos entre los países sudamericanos, a fin de fortalecer la cooperación regional en la materia. 
En el fondo, el CDS buscaría favorecer el tratamiento de los asuntos de defensa de la región bajo una perspectiva sudamericana, favoreciendo un ambiente de confianza y estabilidad entre los países miembros, evitando la injerencia de potencias extrarregionales, particularmente de Estados Unidos -tan presente en su relación con Colombia, por no hablar de la historia latinoamericana-, y favoreciendo la generación de un pensamiento y una identidad común en defensa, así como la integración de las industrias de defensa de los países miembros.

Revisado el estado del arte y la literatura disponible, es posible apreciar que los temas que abarca el estudio son ciertamente novedosos, sobre los cuales no existe una abundante bibliografía, por cuanto, a nivel general, los trabajos referidos a los asuntos de integración regional se han concentrado en los aspectos económicos y comerciales, dejando en un plano secundario los temas de defensa. A su vez, las materias relacionadas con la seguridad regional y las políticas exteriores se han concentrado principalmente en las relaciones bilaterales de los países y la existencia de diferendos limítrofes, dejando de lado la perspectiva regional.

Por otro lado, los estudios sobre seguridad y defensa se han abordado mayoritariamente desde la perspectiva de las teorías Realista o Neo-Realista de las Relaciones Internacionales (Mares, 2012; Arce, 2010; Resende-Santos, 2007; Mares y Bernstein, 1998), que se caracterizan por mantener una apreciación pesimista sobre las relaciones entre los países, entendidas como vinculaciones esencialmente conflictivas, donde los actores son altamente competitivos y tenderían al choque, siendo la guerra la mayor manifestación de esta continua conflictividad y lucha por la propia supervivencia en un escenario básicamente anárquico, como el descrito por Hobbes en su noción sobre el Estado de Naturaleza.

Este paradigma se ha constituido como el pensamiento hegemónico en los estudios de seguridad internacional, lo que fue particularmente notable durante el período de la Guerra Fría, cuando se asumía que la Unión Soviética planteaba una poderosa amenaza ideológica y militar para Occidente (Herz, 2014: 124), haciendo hincapié en los temas tocantes al conflicto o sus posibilidades. Este 
pensamiento ha tenido una fuerte influencia en los estudios elaborados en las academias militares de América Latina.

Al revés, la presente investigación se enfocará desde la perspectiva de la Teoría de la Integración, enfatizando en la relación positiva que se puede observar en las tendencias que expresa la integración regional y los temas de seguridad en América del Sur, particularmente en lo referente a la fluida cooperación en defensa que se aprecia entre los países, donde paulatinamente se ha abandonado el uso de la fuerza, léase la guerra, como un mecanismo de solución de las controversias, aunque ello no implique la ausencia total de conflictos, que son propios de toda relación social, sobre todo las que se dan en el campo internacional.

Para los efectos del desarrollo del análisis, la pregunta que guiará el estudio será la siguiente: ¿Existe una comunidad de seguridad en América del Sur? En virtud de lo anterior, la investigación sigue una hipótesis de trabajo que sostiene que, considerando los avances que exhibe América del Sur en materia de integración regional, particularmente con el desarrollo que exhibe el CDS, es posible sostener la existencia de una comunidad de seguridad, donde los países deciden solucionar sus problemas por medios pacíficos antes que a través del recurso a la guerra.

Como objetivo general, el estudio pretende analizar la conformación de una comunidad de seguridad en el ámbito sudamericano, considerando los aportes del CDS y sus antecedentes a nivel subregional en el Cono Sur y la región Andina. Asimismo, los objetivos específicos son analizar a la región bajo el prisma de la Teoría de la Integración, y su relación con el ámbito de la paz y seguridad; así como caracterizar a la región de América del Sur como una Zona de Paz, describiendo el establecimiento y desarrollo del CDS y los diversos liderazgos nacionales que se pueden observar desde su establecimiento.

Considerando que no existe una abundante bibliografía sobre la materia, la investigación tiene un carácter descriptivo y explicativo. Con este fin, se ha analizado la bibliografía en la temática, declaraciones de autoridades, informes de prensa y documentación oficial de organismos regionales y subregionales. También, el estudio ha contemplado la realización de entrevistas a actores claves, vinculados directa o indirectamente con la temática en análisis. En tal sentido, se 
han llevado a efecto entrevistas libres a autoridades y funcionarios de las instituciones que se han establecido al amparo del CDS, de Ministerios de Relaciones Exteriores y de Defensa de la región, así como a académicos que se han especializado en las materias que abarca esta tesis doctoral.

Por último, en lo relacionado con la estructura del trabajo, cabe señalar que éste se dividirá de la siguiente manera: Primero, se realizará un análisis teórico sobre la relación entre integración regional y seguridad, poniendo énfasis en el concepto de Comunidad de Seguridad y su aplicación al caso sudamericano. Luego se realizará una caracterización del escenario internacional contemporáneo, definido como un sistema crecientemente multipolar, así como sobre el lugar de la región en el mismo. El siguiente capítulo aborda el contexto regional, bajo la perspectiva de la performance de la democracia y su relación con la existencia de una Zona de Paz en América del Sur. El apartado posterior aborda la relación entre integración y seguridad en la región, analizando los diversos antecedentes con que cuenta el Consejo de Defensa Suramericano. Luego, la investigación se enfoca en el establecimiento y desarrollo de dicho consejo, como expresión de una comunidad de seguridad en la región, explayándose en los temas de mayor relevancia que se abordan en tal instancia regional. El último capítulo analiza los diversos liderazgos que se aprecian en los trabajos del Consejo, desde su establecimiento en el año 2008. 


\section{2.- La relación entre integración regional y seguridad: Una perspectiva teórica sobre las Comunidades de Seguridad}

El paradigma realista o hobbesiano ha sido el predominante en la disciplina de las Relaciones Internacionales. Bajo este enfoque, las relaciones entre los Estados serían esencialmente conflictivas, competitivas y tenderían al choque, a la manera de las bolas de billar. Siendo así, la guerra estaría por doquier latente, cuando no desatada, representando la mayor manifestación de esta continua conflictividad. Así las cosas, el Estado sería el actor fundamental, definiendo su conducta en virtud de la continua lucha por la propia seguridad y supervivencia, en un contexto internacional básicamente anárquico, similar al concepto de Estado de Naturaleza definido por Thomas Hobbes, donde prima la autoayuda y los intereses nacionales.

Pero desde un enfoque radicalmente distinto, es posible también apreciar las tendencias del mundo en su vertiente positiva. Desde el pensamiento idealista o kantiano, al revés del realismo, se sostiene que las relaciones internacionales deberían basarse en la ética y la razón, dando lugar a un orden internacional basado en la cooperación y en la existencia de normas comunes, que podrían identificarse con el derecho internacional, no existiendo de este modo la anarquía que plantea el anterior paradigma. El ideal de sociedad internacional estaría marcado por la futura existencia de un Estado universal, en un contexto global donde la guerra sea descartada, bajo los principios de la razón, que señalan que los hombres buscan el placer y evitan el dolor, lo que en el plano internacional implicaría la continua búsqueda de la paz.

Entre ambas posturas estaría una posición intermedia, susceptible de calificar como institucionalista, para la cual las relaciones internacionales no son ni pura cooperación ni puro conflicto, regulando los Estados su conducta, mediante instrumentos como las organizaciones multilaterales y el derecho internacional. Con un enfoque cercano a este paradigma, en el ya clásico libro Poder e interdependencia. La política mundial en transición, Robert Keohane y Joseph Nye caracterizaban al mundo por su interdependencia global, es decir, una situación marcada por los efectos recíprocos entre los países $u$ otros actores en diferentes 
Estados, derivados de los cada vez más intensos flujos de dinero, bienes, personas y comunicaciones a través de las fronteras. La interdependencia compleja comprendía una nueva etapa mundial, donde el Estado territorial, actor predominante en la política internacional durante cuatro siglos, paulatinamente perdía fuerza ante el desarrollo de actores no territoriales, como las empresas multinacionales, los movimientos sociales y las organizaciones multilaterales regionales e internacionales. Más relevante aún, en el plano de la seguridad, era que bajo las condiciones de interdependencia la fuerza física, es decir, la guerra, se presentaba como un instrumento político anacrónico para la resolver los conflictos (Keohane y Nye, 1988). De este modo, el instrumento militar, más que una herramienta de coacción, pasaba a conformarse en un medio más del relacionamiento y cooperación interestatal.

En un trabajo posterior, Keohane analizaba la política mundial bajo el prisma del institucionalismo neoliberal. Bajo esta perspectiva, reconociendo que los Estados seguían siendo actores prominentes en los asuntos mundiales, el autor destacaba el creciente proceso de institucionalización multilateral de las relaciones internacionales, lo que tenía un efecto significativo en el comportamiento de los gobiernos, por cuanto se relacionaba directamente con las posibilidades de comunicarse y cooperar entre ellos. De tal modo, el autor definía las instituciones como "conjuntos de reglas (formales e informales) persistentes y conectadas, que prescriben papeles de conducta, restringen la actividad y configuran las expectativas" (Keohane, 1993: 16-17).

Considerando este enfoque, es posible valorar el establecimiento y desarrollo del CDS, como una institución multilateral de carácter regional, enfocada en los temas relacionados con la cooperación en defensa de los países miembros. Para los efectos del trabajo, se asumirá que el CDS está cumpliendo un rol en materia de seguridad regional, favoreciendo la cooperación y el intercambio de bienes y comunicaciones entre los países sudamericanos en materias de defensa. Lo anterior ha contribuido al incremento de la confianza, bajando los costos de las transacciones y favoreciendo la institucionalización y predictibilidad de las conductas de sus miembros, lo que consecuentemente ha minimizado los riesgos de enfrentamiento e incertidumbre. En suma, como herramienta multilateral, el 
CDS favorecería un ambiente regional estable y cooperativo, al mismo tiempo que su mismo establecimiento ha sido el fruto del mismo, en una dinámica virtuosa caracterizada por la paz sudamericana.

La idea que trasciende esta investigación, utilizando los conceptos aportados por Joseph Nye, es que las fuerzas militares no sólo pueden ser apreciadas bajo el prisma del poder duro de la fuerza física y la coerción, sino también desde sus aportes al poder blando, como parte de una agenda de seguridad benigna y asociativa, definida por la cooperación entre los Estados, sus agencias y los diversos actores no estatales (véase Nye, 2011: 25). La región de América del Sur es un buen ejemplo de lo anterior, como lo evidencian los avances de la agenda de cooperación en defensa, cuyas bases primigenias se desprenden de la siguiente afirmación expresada desde Brasil por el ex Vicecanciller Samuel Pinheiro Guimarães, según el cual:

"La estrategia brasileña de defensa ve al continente sudamericano de forma integrada y considera la cooperación militar entre las Fuerzas Armadas, inclusive en términos de industria bélica, como un factor de estabilidad y de equilibrio regional a través de la construcción de confianza" (Pinheiro Guimarães, 2007:125).

Habiendo llegado a este punto, es necesario señalar que si bien no se constituye como una condición sine qua non de la integración, la confianza resulta fundamental para este proceso. La confianza es el lubricante que dinamiza las relaciones en todo sistema social, generando expectativas de mutuas relaciones pacíficas. En suma, otorga un ambiente estable y propicio para el desarrollo de sus miembros. Como se verá en el trabajo, la labor del CDS ha sido relevante en tal sentido.

Sin embargo, cabe señalar que el tema de la integración y de la estabilidad regional sudamericana no cuenta con el consenso entre los estudiosos y académicos, existiendo miradas pesimistas y optimistas al respecto. Por ejemplo, el profesor de la Universidad de California, David Mares, sostiene en el libro Latin America and the illusion of peace (2012), que la realidad regional está marcada 
por la conflictividad, con una tendencia hacia la militarización de las disputas mediante amenazas verbales y movimientos de tropas-, como medio de negociación internacional. Según Mares, la región de América Latina está plagada de conflictos y contenciosos bilaterales pendientes -como es el caso entre Bolivia y Chile y entre Venezuela y Guyana, entre muchos otros-; disputas ideológicas entre los gobiernos y tendencias hacia el nacionalismo; competencia por recursos naturales y energéticos; problemas medioambientales; desigualdad socioeconómica y pobreza; empoderamiento y frustración ciudadana ante gobiernos incapaces de responder a crecientes demandas; movimientos indígenas en contra de ciertos Estados; un fluido movimiento de capitales e inversiones al interior de la región, que potencialmente pueden transformarse en fuente de disputas internacionales; porosidad de las fronteras, lo que actúa como aliciente para el crimen organizado transnacional, particularmente del narcotráfico; y la utilización, por parte de ciertos gobiernos, de los medios militares para enfrentar situaciones de seguridad interna, con los riesgos que ello conlleva en países con democracias poco consolidadas. Todo lo anterior, en un contexto regional que no posee mecanismos adecuados y fuertes para la resolución de las disputas entre los Estados.

En las academias militares se tiende a coincidir con este diagnóstico pesimista sobre la realidad regional. Por ejemplo, en un artículo aparecido en el Memorial del Ejército de Chile, el General Mario Arce delinea una región caracterizada por el establecimiento de ejes políticos "que varían según el signo de los gobiernos de turno y que generan más confusión que alianzas efectivas" (Arce, 2010: 31), junto a numerosos conflictos pendientes entre los países sudamericanos. En suma, el General Arce plantea que:

"Las relaciones entre los países de la región sudamericana han sido siempre complejas. La presencia de conflictos políticos, sociales y de interés soberano ha sido la tónica permanente al momento de relacionarse. Hoy por hoy dichas relaciones se encuentran, como siempre, complicadas y entrampadas en factores de difícil solución" (Arce, 2010: 29). 
Sin embargo, la presente investigación se posiciona desde una perspectiva más optimista, haciendo hincapié en los beneficios de la integración regional en materia de defensa. Es decir, analiza la relación positiva que es posible apreciar a nivel sudamericano, en la relación entre integración y seguridad, enfocándose en la conformación de una comunidad de seguridad en América del Sur -de carácter pluralista, desde la terminología planteada por Karl Deutsch (1974)-, en el marco de una región que desde la literatura especializada, así como desde distintos organismos regionales e internacionales, se ha definido como una Zona de Paz. Como señala Arie Kacowicz (2014), América del Sur se constituye como la región más pacífica del mundo, donde los países resuelven pacíficamente sus disputas, mediante negociaciones directas, mediación y procedimientos jurídicos, especialmente el arbitraje.

En el plano teórico, cabe destacar que existen distintas perspectivas como autores para abordar el fenómeno de la integración, no existiendo acuerdo, por ejemplo, en si la integración se refiere a un estado, o bien a un proceso. En el presente trabajo se asume la segunda de estas opciones. La integración es un fenómeno complejo sobre el cual es difícil encontrar una definición mínimamente aceptada entre los especialistas.

No obstante, se debe señalar que existe un cierto consenso en que su desarrollo se debe a la existencia de valores compartidos entre los actores, antes que debido a la presencia o uso de la fuerza y la coacción entre ellos. Es decir, la integración siempre es consensual, en tanto se relaciona con procesos de toma de decisiones colectivas. En resumidas cuentas, la construcción regional se relaciona con el proceso que deriva de la "...decisión gubernamental de coordinar políticas nacionales en pos de un resultado (bienes regionales) que no podrían obtenerlos por sí solos" (Botto, 2015, 19). Una útil definición entrega Karl Deutsch, quien define la integración como un proceso:

“...mediante el cual los actores políticos pertenecientes a distintos sistemas nacionales se persuaden de la conveniencia de trasladar sus lealtades, expectativas y actividades políticas hacia un nuevo 
centro, cuyas instituciones pasan a poseer o reclamar jurisdicción sobre los Estados nacionales preexistentes" (En Wilhelmy, 1988).

Los orígenes de la teoría de la integración pueden situarse en el período que se da entre las dos Guerras Mundiales, fundamentalmente con los aportes funcionalistas de David Mitrany, aunque su mayor dinamismo se dio a partir de la Segunda Guerra Mundial, retroalimentándose con el proceso de integración que comenzó a desarrollarse en Europa, lo que produjo una suerte de convergencia virtuosa entre la teoría y la práctica. A partir de la Segunda Guerra Mundial, en el marco de la corriente neofuncionalista, destacan autores como Ernst Haas, Leon Lindberg y Philippe Schmitter, entre otros. Una tercera corriente es la transaccionalista, con autores como Karl Deutsch y Amitai Etzioni.

En un nivel general, puede sostenerse que todo proceso de integración implica el avance hacia el establecimiento de decisiones colectivas, lo que involucra la reingeniería de las políticas de los países a las nuevas realidades de un contexto de construcción de una comunidad. Este sería el sentido de la integración, que se constituye como un proceso que intenta generar un todo con las partes, transformando unidades previamente separadas en componentes de un sistema coherente, cuya característica esencial en tanto sistema es el alto nivel de interdependencia entre sus componentes.

La integración es, por lo tanto, una relación entre unidades, en la cual éstas son interdependientes y conjuntamente producen propiedades del sistema de las que carecerían por separado. Un aspecto fundamental de un sistema integrativo sería, por lo tanto, la producción de bienes públicos regionales relacionados con la capacidad de "trabajar juntos" y generar grados de predictibilidad en las conductas y comportamientos de los actores involucrados.

Desde esta perspectiva, es posible apreciar que los ensayos de integración regional y subregional en América del Sur, al constituirse como foros de cooperación y diálogo, han favorecido un modelo estable y predecible de relaciones. Así, bajo la perspectiva de este trabajo, la integración tendería a bajar los costos de las transacciones, facilitando el intercambio de información y 
reduciendo la incertidumbre y las posibilidades de conflicto entre los países que participan del proceso.

Al participar en un proceso de integración los países dejan de ser totalmente soberanos, al tener que someter parte de sus atributos en favor de la comunidad ampliada. Pero esta sesión no es gratuita ni basada puramente en los supuestos idealistas de la armonía de intereses, por cuanto los Estados voluntariamente adhieren a un determinado proceso integrativo porque creen que de este modo satisfarán de mejor manera sus intereses nacionales. Desde un punto de vista complementario, es posible también argumentar que mediante la integración los países ganan atributos de soberanía, por cuanto actuando conjuntamente los Estados pueden incidir de mejor manera en los procesos de toma de decisión internacionales. Esta noción está en el centro de los planteamientos que dieron cuerpo al Consejo de Defensa Suramericano (Riquelme, 2016).

Por otro lado, cabe señalar que la acción o presencia de un enemigo exterior, o la presencia de amenazas por parte de un actor exógeno, pueden actuar como un factor aglutinante que apuntale la integración. La carencia de este "enemigo externo" puede ser uno de los factores que influya en los poco institucionalizados procesos de integración en América del Sur, lo mismo que la carencia, hasta ahora, de un líder firme y constante para la integración, como fueron Alemania y Francia en el proceso europeo. También ha sido un factor relevante la inexistencia en América del Sur de una "idea fuerza" o "fundacional", como lo fue la paz en Europa, luego de la devastación generada por la Segunda Guerra Mundial.

Otro rasgo común es el foco que los autores ponen en el proceso mediante el cual la lealtad de los actores nacionales pasa desde un centro a otro, que progresivamente comenzará a reclamar jurisdicción sobre las antiguas unidades, y la valoración que entregan a las comunicaciones entre las unidades que se integrarán. Igualmente, es común entre los teóricos de la integración, la idea de la ramificación o "efecto derrame", que supone que el desarrollo de la colaboración en un área, progresivamente llevará a un comportamiento semejante en otros ámbitos. Como sostienen Dougherty y Pfaltzgraff: 
"El esfuerzo por crear un mercado común, por ejemplo, da surgimiento a presiones para una colaboración ulterior en la determinación de precios, inversión, transporte, impuestos, salarios, seguridad social, bancos y políticas monetarias" (Dougherty y Pfaltzgraff, 1993: 444).

Es decir, todo proceso integrativo presenta una dinámica "incrementalista" o de "bola de nieve", es decir, posee una lógica expansiva que extrapola la integración, que en un principio suele aparecer como más visiblemente económica, hacia otras áreas de mayor contenido político. Generalmente, las áreas más difíciles para la integración son aquellas más sensibles para la soberanía nacional, como son los temas relativos a la seguridad y defensa. Este es el caso de las manifiestas reticencias de los Estados a someter sus fuerzas militares a mandos extranjeros (Magariños, 2000: 22). ${ }^{3}$ Sobre el particular, Gustavo Magariños plantea que:

"En teoría, la integración una vez iniciada, aunque esté primeramente restringida a un sector, planteará progresivamente la necesidad de armonizar instrumentos y coordinar políticas en otras áreas. El ejercicio de una política exterior común induciría a adoptar un sistema de defensa coordinada y viceversa. La unión económica propulsará una mayor integración política y el establecimiento de una comunidad política tendría como consecuencia una integración económica más amplia y profunda" (Magariños, 2000: 24).

En esta línea, es posible avizorar que la reflexión sobre la experiencia de América del Sur puede constituirse como un singular aporte para la teoría de la integración, por cuanto siendo conocidas las dificultades que ha encontrado la integración

\footnotetext{
${ }^{3}$ Como se verá más adelante, en el Cono Sur de América Latina, el buen nivel de relaciones bilaterales que han alcanzado Chile y Argentina ha tendido a superar estos supuestos, como lo expresa la constitución de la Fuerza de Paz Conjunta Combinada Cruz del Sur.
} 
regional en sus aspectos comerciales -entre otros elementos, debido a las divergentes estructuras arancelarias, las políticas proteccionistas y la preferencia de los países por alcanzar acuerdos bilaterales con socios más allá de la región, lo que ha redundado en continuos periodos de estancamiento de los flujos de comercio intrarregional- lo cierto es que, en el ámbito de la defensa, la integración ha sido particularmente exitosa. Este trabajo se guía bajo el supuesto de que la integración política en América del Sur, específicamente en el plano estratégico, ha sido considerablemente más exitosa que la integración económico-comercial.

Ahora bien, desde sus orígenes, la teoría de la integración se planteó como una respuesta al realismo, que ponía énfasis en la conflictividad y la competencia entre los actores estatales. Desde sus orígenes en el funcionalismo, la teoría de la integración se centraba en las tendencias a la cooperación de los Estados y en la armonía de intereses entre éstos, con miras a lograr y consolidar la paz. De tal modo, el tema de la paz y seguridad estuvo en un lugar de relevancia de esta teoría desde sus inicios. El caso europeo fue particularmente evidente, en tanto el proceso de integración se concibió desde su comienzo como una estrategia para avanzar en el desarrollo y mantener la paz en un continente destruido por la guerra. De hecho, como señala el profesor Celestino Del Arenal, una de las características esenciales de la integración, es la existencia de condiciones que permitirían avanzar en el camino de la superación de las diferencias, tensiones y conflictos entre las diversas unidades políticas, sin recurrir a la guerra (Del Arenal, 2003: 259).

De todos modos, cabe señalar que el ejemplo europeo tiene sus matices, como lo expresa el dificultoso camino que ha debido recorrer la política exterior y de defensa común de la Unión Europea. Al respecto, actualmente se aprecia que, en este ámbito, los países han preferido conducirse de acuerdo a sus respectivos intereses nacionales -contando con la OTAN para mantener la paz-, entre otros elementos, debido a los diversos intereses, prioridades y visiones de mundo, así como a la inexistencia de una cultura estratégica común. Estas divergencias fueron particularmente evidentes durante la Guerra de Irak y lo siguen siendo, por ejemplo, respecto de las relaciones de Europa con la Federación de Rusia (véase 
Grant, 2009), lo que resulta particularmente visible en el caso de la situación de Ucrania.

La teoría de la integración vivió un fuerte repunte desde la década de los noventa, ante el nuevo escenario internacional que se comenzó a delinear tras el fin de la Guerra Fría y los diversos procesos de integración que ganaron fuerza en diversas regiones del mundo, como fue el caso del Mercado Común del Sur (MERCOSUR), a partir de 1991.

Este nuevo escenario global planteó, asimismo, nuevos enfoques en los estudios estratégicos, como efecto del debate que se planteó en la comunidad internacional respecto de la ampliación del tradicional concepto de seguridad, de carácter eminentemente interestatal. Como señala la profesora Mónica Herz, la ampliación del concepto involucró tres principales movimientos teóricos: la internacionalización de la seguridad; la incorporación de esferas no militares de interacción; y la añadidura de nuevas fuentes de amenazas, objetos y temas para el debate (Herz, 2014, 126).

En el terreno multilateral, como parte de un diálogo al que después se incorporaría la Organización de Estados Americanos (OEA), ya en 1982 la Comisión de Desarme y Asuntos de Seguridad, presidida por Olof Palme, propuso una nueva agenda de seguridad, que superara la doctrina de la disuasión mutua por la de seguridad común, incorporando nuevos temas como la disparidad social y económica, los temas ambientales y el control de los armamentos. Eran los primeros pasos hacia la posterior definición del concepto de la Seguridad Humana, del cual posteriormente derivaría el principio de la Responsabilidad de Proteger, tan vigente en los debates políticos y académicos que actualmente se desarrollan en el mundo, en atención a la compleja situación del Medio Oriente (Salgado, 2016; Arredondo, 2014; Orchard, 2012).

La interdependencia planteada en el mundo como efecto del dinamismo que adquirió el proceso de globalización, en el marco de la Posguerra Fría, impregnaría los estudios sobre seguridad y asuntos estratégicos. En esta línea, Barry Buzan y Ole Wæver (2003), incorporando al análisis a las regiones, plantearon la teoría de los Complejos de Seguridad Regional. Este cuerpo teórico basa su estudio en las relaciones entre países próximos, que suelen considerarse 
como la mayor fuente de inseguridad, por cuanto las amenazas suelen viajar distancias cortas.

La teoría de los Complejos de Seguridad de Regional enfoca el nivel del análisis estratégico en el ámbito que media entre los Estados y el sistema político internacional como un todo (Buzan, 2009: 157), destacando que existe un subsistema regional, con una relativa autonomía en el patrón de relacionamiento en el plano de la seguridad, en el entendido que ella posee un carácter eminentemente relacional, donde la realidad estatal no puede ser sustraída del contexto en el cual cada Estado está inmerso. Si bien esta teoría mantiene ciertos supuestos del realismo respecto del carácter esencialmente anárquico del escenario internacional, no obstante, reconoce la necesidad de superar el tradicional etnocentrismo que prima en el análisis de la seguridad nacional, incorporando los indivisibles modelos de relacionamiento entre los Estados, cuyos asuntos de seguridad están fuertemente interconectados.

Respecto del hemisferio, Buzan y Wæver sostienen que Norteamérica y Sudamérica exhiben diferentes dinámicas de seguridad y altos niveles de asimetrías. Por una parte, América del Norte estaría determinada por la existencia de un gran superpoder, Estados Unidos. Por otra, el complejo sudamericano estaría compuesto por el área andina y el Cono Sur, representando cada uno de estos un subcomplejo (Buzan y Wæver, 2003, 263). Lo que interesa destacar es que, bajo este enfoque, la seguridad de los países suramericanos no puede entenderse sin analizar a la región como un todo, razón por la cual resulta especialmente pertinente analizar los aspectos estratégicos que exhibe la integración sudamericana, sobre todo en el marco de las transformaciones y tendencias que se aprecian actualmente en la geopolítica regional.

En línea con lo anterior, un complejo de seguridad sería definido como un "conjunto de Estados cuyas percepciones y preocupaciones de seguridad están tan vinculadas que sus problemas de seguridad nacional no pueden ser razonablemente analizados o resueltos de manera autónoma" (En Bárcena, 2000: 22). Bajo la perspectiva del presente trabajo, resulta relevante no sólo que los países próximos son la mayor fuente de inseguridad, si no también que forman parte sustancial de las soluciones, en tanto la seguridad de los países, en el 
contexto interdependiente actual, se alcanza de manera cooperativa. En este orden de ideas, se entenderá que el propósito de la seguridad cooperativa es prevenir la guerra, evitando que se conjunten los medios necesarios para una agresión. Según señala Martha Bárcena:

“Su principio clave sería lograr el 'compromiso cooperativo' de todos los Estados para regular el tamaño, la integración técnica, los flujos de inversión y las prácticas operativas de las fuerzas militares de los países, por mutuo consentimiento y para beneficio de todos" (Bárcena, 2000: 18).

En complemento de lo anterior, Mario Laborie sostiene que, considerando los debates políticos y académicos actuales sobre los alcances del concepto de la seguridad, “...es quizás la Seguridad Cooperativa la fórmula que ha alcanzado un mayor reconocimiento. Se parte de la certeza de que ningún Estado o grupo de Estados, de manera aislada, pueden afrontar los problemas actuales". A lo anterior, Laborie agrega la dimensión relativa a los actores que es preciso considerar en el análisis de tal concepto, por cuanto la concepción tradicional de la seguridad nacional se entendía como un asunto eminentemente estatal, mientras que la noción de la seguridad cooperativa pasa a incluir a los actores no estatales e intergubernamentales, en tanto “...cualquier solución estable sólo puede obtenerse si se conciertan las acciones y efectos procedentes del ámbito diplomático, informativo, militar, económico, político o civil”. En tal sentido, es preciso avanzar hacia una perspectiva multidimensional, sobre la base de la conjunción de las denominadas tres $\mathrm{D}$ de la seguridad: Defensa, Diplomacia y Desarrollo (véase Laborie, 2011: 3-4). ${ }^{4}$

\footnotetext{
${ }^{4}$ Por su parte, el concepto de Seguridad Colectiva corresponde a "un sistema de estados que se asocian, usualmente firmando un tratado, y adoptan un compromiso expreso por el que realizan dos cosas:(1) renuncian al uso de la fuerza para resolver las disputas con otro, y (2) prometen usar la fuerza contra cualquiera de ellos que rompa la primera regla". En este esquema, "El agresor debe ser disuadido por la perspectiva de una aplastante coalición. Si la disuasión fracasa, el agresor será derrotado por la acción militar emprendida por esta coalición...Según la seguridad colectiva todos los demás Estados del sistema se convertirán automáticamente en aliados en caso de agresión. Las alianzas en cualquier otra ocasión sólo podrían despertar sospechas. La seguridad colectiva hace posible que los Estados renuncien al uso de la fuerza asegurándoles que no dejarán de ser socorridos si otro Estado utiliza ilegalmente la fuerza contra ellos" (Calduch, 1993: 4).
} 
Desde la Teoría de la Integración, Karl Deutsch plantea que el establecimiento de instituciones y prácticas formales de relacionamiento entre los países de una región determinada, favorece el cambio pacífico y la práctica de relaciones estables y predecibles entre los actores, los que en consecuencia abandonan a la guerra como mecanismo para la solución de las controversias que pudieren suscitarse entre ellos. Según Deutsch, la integración puede comprender el fomento de dos tipos de comunidades de seguridad: las amalgamadas, donde las unidades políticas antes independientes han formado una sola unidad con un gobierno común; y las pluralistas, donde los gobiernos separados mantienen su independencia legal (Deutsch, 1974: 231). Este segundo tipo de comunidades posee tres condiciones esenciales para su existencia:

1. Compatibilidad de los valores políticos fundamentales.

2. Capacidad de los gobiernos y de los estratos políticamente importantes de los países participantes, para responder en forma recíproca a los mensajes, necesidades y acciones, en forma rápida, adecuada y sin recurrir a la fuerza.

3. Predictibilidad mutua de los aspectos relativos a la conducta política, económica y social de unos respecto de los otros (Deutsch, 1974: 231).

En el fondo, según Deutsch, una comunidad de seguridad estaría determinada por el logro de un sentido de comunidad en un territorio determinado, con instituciones y prácticas fuertes y extendidas, en orden a asegurar expectativas de cambio pacífico entre los Estados. Siguiendo la conceptualización planteada por Karl Deutsch, Emmanuel Adler y Michael Barnett señalan que una comunidad pluralista de seguridad correspondería a una región transnacional, compuesta por Estados soberanos cuya población mantiene expectativas sólidas de un cambio pacífico. En una comunidad de estas características, la función de las fuerzas armadas ya no sería la de intimidar, sino la de proteger a los Estados miembros ante una agresión externa (En Fuchs, 2006 : 31). En consecuencia, una reflexión moderna sobre la paz regional no se relacionaría con la ausencia de conflictos y 
diferencias, sino a una manera racional de abordarlos, buscando una resolución que no involucre el uso de la fuerza o, puesto en otros términos, el recurso a la guerra.

Complementando estos postulados, Emmanuel Adler se refiere a las comunidades de seguridad en el contexto posterior al fin de la Guerra Fría. Según Adler (2001), a partir de ese momento el escenario internacional entraría en "la edad multilateral" (the multilateral age), caracterizada por los incentivos a la cooperación entre los países, sobre la base de valores y normas comunes, y por la pérdida de valor de los tradicionales recursos de poder de los Estados. De este modo, siguiendo a Deutsch, Adler define una comunidad de seguridad como una región compuesta por Estados soberanos, cuyos pueblos mantienen mutuas expectativas de cambio pacífico (Adler, 2001: 146).

De manera complementaria con lo anterior, Arie Kacowicz distingue tres categorías y tipos de paz: la paz negativa, la paz estable y la comunidad pluralista de seguridad. La paz negativa se refiere a la ausencia de guerra en las relaciones internacionales, donde la paz se mantiene por medio de amenazas, disuasión, equilibrio de poder, hegemonía, falta de capacidad o voluntad de llevar a cabo acciones bélicas o limitaciones geopolíticas. En este marco, la guerra sigue siendo tangible y real. Por otro lado, la paz estable se define como una situación donde la probabilidad de una guerra es tan pequeña que prácticamente no entra en los cálculos de los actores involucrados. La paz se mantiene de manera recíproca y consensual. En estas condiciones, los conflictos son resueltos por la vía pacífica. Por último, según Kacowicz, la comunidad pluralista de seguridad sería un caso de paz estable en una región determinada, donde los países miembros mantienen expectativas de resolver sus conflictos pacíficamente. Siguiendo a Deutsch, el autor señala que la comunidad es pluralista, en el sentido que los países mantienen su independencia legal y propia identidad. En este marco, los países comparten normas y valores, instituciones políticas comunes y hasta adquieren una identidad común. En tal marco, la paz es asumida como una realidad inexorable, compartiendo elementos con la teoría de la paz democrática, según la cual los Estados democráticos no van a la guerra entre sí (Kacowicz, 2014: 143144; también Holsti, 1996; y Battaglino, 2012). 
Profundizando en el análisis de las comunidades de seguridad, Charles Kupchan señala que en éstas, los Estados avanzan más allá de las mutuas perspectivas de relaciones pacíficas, para configurar consensualmente un conjunto de normas y reglas para guiar sus interacciones, institucionalizando códigos de conducta con miras al logro de intereses y objetivos conjuntos. En último término, la característica definitoria de una comunidad de seguridad sería la existencia de una identidad compartida entre las partes. De este modo, sería posible distinguir otros tres tipos de comunidades de seguridad. Una comunidad de seguridad naciente, donde los Estados miembros acuerdan superar sus disputas pacíficamente, identificando mecanismos rudimentarios para ello, y donde aún perviven las desconfianzas mutuas. Por otro lado, una comunidad de seguridad ascendente, en la cual los miembros acuerdan un más extensivo conjunto de normas y reglas de comportamiento, institucionalizando e incluso codificando esas pautas. $Y$ por último, se puede distinguir una comunidad de seguridad madura, donde los Estados disfrutan de un orden constitucional, en el cual un conflicto armado se hace impensable, como sería el caso de la Unión Europea (véase Kupchan, 2010: 183-184).

A su vez, siguiendo a Adler y Barnett, Flemes, Nolte y Wehner plantean que, en virtud de su grado de institucionalización, existirían dos tipos de comunidades de seguridad. La primera, es más bien flexible o laxa y la segunda, más rígida y rigurosa. El primer tipo supone un grado de institucionalización menor, ya que los Estados soberanos que la componen solo reducen sus expectativas a cambios pacíficos, mientras que las segundas tienen un grado mayor de institucionalización en las prácticas y exhiben un principio de ayuda mutua, cuyo objetivo es generar una estructura sólida de gobernanza (Flemes, Nolte y Wehner, 2011: 113).

Junto con lo anterior, cabe señalar que el tema de la identidad ha marcado fuertemente los últimos estudios sobre las comunidades de seguridad, donde han destacado los aportes que se han realizado desde el Constructivismo, en su análisis sobre la formación de las identidades colectivas. Un conocido argumento de Alexander Wendt, un autor prominente de este paradigma, señala que "la anarquía es lo que los Estados hacen de ella" (Wendt, 1992). Es decir, como señala Elsa LLenderrosas, la lucha por el poder, los dilemas de seguridad y la 
guerra no serían rasgos inevitables de las relaciones internacionales. Si se transforma la calidad de la interacción, los Estados pueden pasar a valorarse como potenciales amigos, no como enemigos, con los respectivos resultados para la convivencia internacional (véase Llenderrosas, 2009: 363).

Según Marina Vitelli, a pesar de que el constructivismo es agnóstico respecto a qué tipo de orden internacional deben impulsar los Estados -un orden basado en el equilibrio de poder, en el derecho internacional o en la extinción del Estado, por ejemplo- varios de sus autores se han dedicado a fundamentar teórica y empíricamente la posibilidad de órdenes basados en sistemas de seguridad cooperativa, sobre la base de significados e incluso valores comunes (Vitelli, 2013: 56). Como constructo social, la identidad nacional es susceptible de ser modificada a favor de una comunidad regional, en la medida que se genera una nueva identidad intersubjetiva, a través de la participación y mutuos intercambios entre los Estados y otros actores sociales en el contexto de foros y mecanismos multilaterales de corte regional. De este modo, la integración tendría relevantes efectos cognitivos, al centrarse en las prácticas compartidas y en la generación de percepciones comunes entre los actores, lo que conllevaría efectos relevantes en el campo de la seguridad, al cambiar los patrones de amistad y enemistad.

Al respecto, siguiendo a John Ruggie, es posible sostener que la integración, como instancia propia del multilateralismo, es "una forma institucional que coordina las relaciones de tres o más Estados, basándose en principios generalizados de conducta" (En Sodupe: 2004: 169). En el mismo tenor se ha expresado Andrew Hurrell quien, analizando las comunidades de seguridad, destaca la importancia de los intereses e identidades compartidos, que se construyen históricamente, en el marco de estructuras normativas e institucionales, en las cuales los intereses estatales son construidos y redefinidos (Hurrell, 1998).

Como es posible vislumbrar, un contexto de integración tiene efectos notables para la seguridad de los países involucrados, los que no pueden ser apreciados en su globalidad bajo el punto de vista de los enfoques tradicionales vinculados con el Realismo y sus supuestos sobre la guerra en su sentido westfaliano. La seguridad de los países ya no puede asumirse unilateralmente ni descansar exclusivamente 
en la acumulación de armamentos y a expensas de los vecinos. Como parte de la interdependencia regional, la seguridad ya no es un juego de suma cero y, por lo tanto, la defensa debe asumirse bajo una perspectiva cooperativa. Es decir, para satisfacer sus cada vez más variadas necesidades de seguridad, los Estados requieren de ámbitos de acción más amplios, donde se supone una acción regional cooperativa entre países con homogeneidades políticas, económicas y culturales.

Considerando todo lo anteriormente expuesto, cabe sostener que en América del Sur la integración ha exhibido un efecto espiral en el ámbito estratégico, que se relaciona con el desarrollo de una comunidad de seguridad, en la cual los países resuelven sus disputas por medios alternativos a la guerra y la coacción, destacándose la consolidación que exhibe el Consejo de Defensa Suramericano. En base a ello, se puede plantear que, en el contexto regional sudamericano, se estaría en presencia de una comunidad de seguridad flexible o laxa, en los términos planteados por Flemes, Nolte y Wehner, pluralista, en los términos sugeridos por Deutsch, y naciente, pero en camino hacia una de carácter ascendente, en la conceptualización de Kupchan (véase Riquelme, 2013: 285286).

En una línea argumental similar, Flemes, Nolte y Wehner plantean que Sudamérica aún estaría lejos de constituir una comunidad de seguridad madura. Más bien, los países de la UNASUR pretenden establecer una comunidad de seguridad rigurosa, que exhibe una cierta institucionalización de las prácticas y donde existe un principio de ayuda mutua, encontrándose en una etapa ascendente de su evolución en pos de generar una estructura sólida de gobernanza en temas de seguridad y defensa (Flemes, Nolte y Wehner, 2011).

Como se señalará más adelante, el que América del Sur avance hacia una comunidad de seguridad madura, como es el caso de la Unión Europea, donde los países miembros no albergan mutuas hipótesis de conflicto y dirigen sus preocupaciones hacia el entorno extrarregional, dependerá de que los países dejen de considerar a los vecinos y otros actores del entorno como potenciales amenazas, desactivando completamente los factores disuasivos de las respectivas políticas de defensa en pos de la plena cooperación. 
Las hipótesis de conflicto vecinal, en el contexto de las respectivas políticas de defensa, aún están vigentes en los procesos de planificación estratégica, pese a estar enmarcadas en una región caracterizada como una Zona de Paz. Existen promisorios ejemplos bilaterales, como es el caso de Chile y Argentina; pero también existen una serie de ejemplos en contrario, como son las situaciones entre Chile-Bolivia, Ecuador-Colombia, Colombia-Venezuela y Venezuela-Guyana, entre otros. No obstante, es necesario aclarar que, si bien aún perviven disputas no resueltas, desconfianzas y competencias bilaterales entre algunos países de América del Sur, lo cierto es que dichas problemáticas se canalizan a través de negociaciones y mecanismos políticos, antes que mediante la coerción y la fuerza física. Como señala Mónica Herz, esta situación ha sido el resultado de una profunda tradición legalista entre las élites sudamericanas, que se ha manifestado en un arraigado apoyo y valoración del multilateralismo como mecanismo de resolución de las controversias internacionales (Herz, 2011). 


\section{3.- El escenario internacional contemporáneo y el lugar de América Latina}

En este apartado se analizan las tendencias que se aprecian actualmente en la política internacional, poniendo énfasis en el proceso de redistribución del poder que es posible observar en el mundo, lo que ha implicado la conformación de un escenario crecientemente multipolar, donde las regiones y ciertos países emergentes, de la tradicionalmente denominada periferia, cobran una cada vez mayor relevancia en la toma de decisiones globales. También se entrega la perspectiva de América Latina en tal sentido, poniendo énfasis en los lineamientos que exhibe la integración regional desde sus orígenes hasta nuestros días, particularmente en el contexto sudamericano.

\section{a) Hacia un mundo multipolar}

El fin de la Guerra Fría implicó cambios trascendentales en la política internacional, que decantó desde un sistema básicamente bipolar hacia uno que transitoriamente mantuvo características que se podrían calificar como unipolares, con Estados Unidos a la cabeza. Así también, el derrumbe del bloque soviético, el fin de los socialismos reales y la expansión de la democracia y el libre mercado por el mundo generaron en un primer momento una generalizada esperanza respecto de la constitución de un nuevo escenario marcado por la estabilidad, la paz, la seguridad y la justicia, en un mundo estructurado en torno a una institucionalidad intergubernamental centrada en el sistema de Naciones Unidas. Era el mundo del Fin de la Historia caracterizado por Francis Fukuyama.

No obstante, las dramáticas situaciones de Ruanda, Somalia, Bosnia y Kosovo, entre otras, daban cuenta de la vigencia de la Historia. A la esperanza y optimismo de comienzos de los noventa, siguió una nueva etapa de desilusión y pesimismo. El nuevo contexto de posguerra estuvo marcado por la proliferación y visibilización política de ciertos conflictos, que habían estado sujetos bajo el manto de la lógica bipolar.

Muchos de éstos tenían un carácter intraestatal y derivaban de problemas socioeconómicos, étnicos, religiosos y culturales, ante los cuales Naciones Unidas evidenció sus incapacidades, inadaptación y escasa operatividad. El 
funcionamiento del Consejo de Seguridad estuvo, y todavía lo está en el presente, en el centro de las críticas.

Asimismo, desde el año 1989, con la caída del Muro de Berlín y el consecuente fin de la Guerra Fría, el proceso de globalización y su secuela de interdependencia cobraron una fuerza radical en el mundo, como efecto de los cambios tecnológicos, particularmente en el ámbito de las comunicaciones y transportes, así como de la propagación de la economía de libre mercado.

Como un proceso de carácter multidimensional, la globalización ha acarreado una serie de cambios en variados ámbitos de la vida social, como son el incremento de los flujos de comercio, personas, finanzas e ideas, entre muchos otros, sin olvidar los relevantes efectos que ha implicado en el terreno de la seguridad internacional. Ante tal avalancha de cambios, los Estados Nación tradicionales no han podido afrontar y proteger efectivamente a sus poblaciones del abanico de desafíos, riesgos y amenazas que supone este marco de interdependencia global, donde últimamente destacan notoriamente los hackers, los cibercriminales y los grupos terroristas. Todo lo anterior ha ido de la mano de la proliferación de nuevos actores no estatales e intergubernamentales, los que han transformado en su misma esencia el tradicional sistema interestatal, constituido a partir de la denominada Paz de Westfalia de 1648. Como señalan Vacas y Rodríguez,

“... la soberanía se desdibuja al no constituir un componente de entidad suficiente frente a los movimientos de capital, de trabajadores, de las informaciones o de las ideas, de manera que el Estado no puede ofrecer la protección efectiva y necesaria para afrontar los riesgos y amenazas que provienen desde fuera" (Vacas y Rodríguez, 2013: 9).

Junto con lo anterior, es necesario señalar que actualmente los Estados están siendo sometidos a una serie de presiones "desde arriba" y "desde abajo". Desde arriba, por el desarrollo del derecho internacional y una serie de organismos intergubernamentales, que monitorean las decisiones y las políticas públicas que implementan los gobiernos. $\mathrm{Y}$ desde abajo, por los cada vez más numerosos 
movimientos étnicos y regionalistas, que reclaman mayores espacios de autonomía.

De tal modo, el sistema internacional westfaliano está siendo socavado desde sus mismos cimientos. Según señala el profesor argentino Juan Gabriel Tokatlián, Westfalia fue un acuerdo diplomático, que procuró organizar la vida política en Europa, basándose en los principios de la soberanía nacional y la no intervención. Con su extensión, este esquema, originariamente europeo, tuvo un alcance mundial: Occidente, por la vía de la expansión de sus imperios, fue propagando el sistema westfaliano, sustentado en la integridad territorial de sus unidades. Además, según este autor, en términos de su modo de actuar, Westfalia se caracterizó por la actitud en favor del statu quo de las principales potencias y sus socios más importantes, como actores satisfechos con el orden imperante (Tokatlián, 2012: 113-114). Tales condiciones han entrado en un proceso radical de cambios.

Tal sistema interestatal está siendo en la actualidad fuertemente impugnado, sin perjuicio de la relevancia que sigue teniendo el Estado como actor principal de la política internacional. Según Tokatlián, es posible constatar un traslado del centro de poder en el mundo, desde occidente hacia oriente, así como el consecuente reacomodo de la influencia desde el Norte hacia el Sur. Ello ha sido particularmente visible con el auge que se aprecia en la proyección internacional de Asia en los campos demográfico, geopolítico y económico, lo que resulta especialmente visible en los casos de China e India. En palabras de Tokatlián:

"La mayor novedad del último cuarto de siglo ha sido el gradual despegue y creciente auge de poderes del Sur. China, India y Brasil, entre otros, constituyen ejemplos de nuevas potencia que irrumpen en el escenario internacional desde una posición de relativa fortaleza y sin pedir permiso...Los nuevos poderes emergentes provienen de la periferia, poseen regímenes políticos diversos, sus casas no están plenamente ordenadas, gravitan significativamente en la economía mundial, están descontentos con los equilibrios de fuerza vigentes, tienen altos niveles de 
desigualdad doméstica, despliegan una conducta externa heterodoxa y se encuentran muy inclinados a favor de una repartición de poder en el terreno global" (Tokatlián, 2012: 114115).

En consecuencia, se asiste a un escenario internacional particularmente complejo y cambiante, marcado por el paulatino traslado y reacomodo del poder en el mundo, con una periferia cada vez más protagónica en los asuntos mundiales en variados ámbitos, aunque sea particularmente visible en el plano de la economía y el comercio internacionales. Si bien en el ámbito militar aún se está en presencia de un mundo unipolar, con Estados Unidos a la cabeza, no existiendo un Estado o grupo de Estados capaces de contrabalancear a la potencia norteamericana, lo cierto es que el mundo posee altos grados de multipolarismo en todas las demás áreas internacionales, como es en el ámbito de la economía, la tecnología y la cultura.

En una conocida analogía, Joseph Nye plantea que actualmente el poder en el mundo está distribuido a la manera de un ajedrez tridimensional. En la cima del tablero, el poder militar es claramente unipolar, con Estados Unidos como actor supremo. Pero en la medianía del tablero, donde se juega el poder económico, el mundo es multipolar desde fines del siglo pasado, con actores tales como el mismo Estados Unidos, así como Europa, Japón y China. Por último, en la dimensión inferior, donde se despliegan las relaciones transnacionales de actores que trascienden el control estatal, el poder es ampliamente difuso, perdiendo todo sentido utilizar en esta esfera conceptos como unipolaridad, multipolaridad o hegemonía (Nye, 2011: xv). En una línea argumental análoga, Juan Gabriel Tokatlián sostiene que:

"Si se mira el sistema internacional en su dimensión militar, para poner un ejemplo, sin duda no se asiste a una condición multipolar. Un indicador de lo afirmado es el último presupuesto de defensa del presidente George W. Bush y el primero del presidente Barack Obama (que son idénticos en materia militar): 
estos equivalen a la suma de los presupuestos de defensa de los restantes ciento noventa y un países con asiento en Naciones Unidas...Ninguna otra potencia o coalición de poderes posee ese dispositivo de despliegue y presencia...en términos estrictamente militares, nadie tiene todavía la capacidad de contrabalancear solitariamente o mediante una alianza cohesiva a los Estados Unidos, ni existe coalición explícita alguna que lo pretenda...lo indicado no implica que se asiste a un escenario unipolar pertinaz y prolongado, sino que se debe tener claridad acerca de los distintos "tableros"-el militar, el diplomático, el económico, el tecnológico, el cultural, el del poder duro, el del poder blando- que se despliegan y entreveran en la política mundial contemporánea" (Tokatlián, 2012:100-102).

Incluso el fallecido historiador marxista Eric Hobsbawm coincide con tales argumentos, en el sentido que se está en presencia de un contexto altamente complejo, donde no se avizora una superpotencia dominante. Según Hobsbawm, "El mundo es demasiado grande, complicado y plural. Y no parece factible que Estados Unidos, ni ninguna otra potencia estatal imaginable, pueda consolidar su dominio, por más que se lo proponga" (Hobsbawm, 2002: 34).

Luego del fin de la Guerra Fría y la decadencia de la transitoria hegemonía estadounidense, se observa a una serie de países emergentes que desafían a las antiguas potencias, las que progresivamente pierden status en el ámbito mundial. En tal sentido, resulta sintomático el que el lema de campaña de Donald Trump a la presidencia de Estados Unidos haya sido "Make America great again". También es el caso de Rusia, cuyo accionar en Ucrania, con la anexión ilegal de Crimea, denota los intentos desesperados de la antigua soperpotencia por recuperar posicionamiento internacional, sintiéndose cercada en sus propias fronteras por occidente, en un contexto de grave estancamiento económico y demográfico.

La profesora Susanne Gratius señala, en el mismo sentido, que actualmente se aprecia un cambio en los cimientos del tradicional mundo triádico dominado por Estados Unidos, Europa y Japón, existiendo ámbitos de unipolaridad que se 
superponen con otros donde predomina la multipolaridad, lo que supone importantes complejidades al momento de caracterizar el escenario internacional contemporáneo (Gratius, 2009). Lo anterior se ha expresado en una ingente actividad multilateral de los países del mundo emergente, como son los países que forman parte del BRICS (Brasil, Rusia, India, China y últimamente Sudáfrica), IBSA (India, Brasil y Sudáfrica), el G-20 (que agrupa a las tradicionales potencias del Norte, así como a las emergentes del mundo del Sur) y el G-4 (formado por Brasil e India junto a Alemania y Japón, cuyo objetivo es alcanzar un asiento permanente en el Consejo de Seguridad de Naciones Unidas). Tokatlián ha calificado estas agrupaciones y su actividad como parte de un "multiminilateralismo", esto es, una activa labor multilateral en variados ámbitos, en los que convergen un número limitado de participantes (Tokatlián, 2011: 153). En tal respecto,

"La mayor novedad del último cuarto de siglo ha sido el gradual despegue y creciente auge de poderes emergentes del Sur. China, la India y Brasil, entre otros, constituyen ejemplos de nuevas potencias que irrumpen en el escenario internacional desde una posición de relativa fortaleza y sin pedir permiso" (Tokatlián, 2011: 155).

En el mismo orden de ideas, Fareed Zakaria (2009) plantea que se estaría presenciando un gran cambio de poder en el mundo, que denomina "la emergencia del resto" ("the rise of the rest"). Esta vasta transformación se expresaría en la configuración de nuevos polos de poder político y económico en el orbe, siendo el caso más representativo el gran dinamismo que exhibe China, cuya presencia en América del Sur resulta determinante para gran parte de las economías de la región. Según Zakaria, este renovado escenario contribuiría a crear un nuevo sistema internacional, en el cual países en variadas partes del mundo se estarían transformando ya no en meros espectadores, sino en actores protagonistas por pleno derecho. 
Como es posible discernir, un ejemplo de la "emergencia del resto" es la pujanza de los países del BRICS en el ámbito de la economía internacional, que según estimaciones de Goldman Sachs, combinando su Producto Interno Bruto (PIB), superarían el PIB combinado de los países del G-7 para el año 2035. Bajo el mismo prisma puede apreciarse el protagonismo que últimamente se observa en el terreno de la política multilateral por parte del G-20 que, agrupando a grandes potencias y potencias emergentes, ha llegado incluso a cuestionar el liderazgo de Naciones Unidas para la resolución de los grandes temas de la agenda económica global.

De tal modo, Tokatlián sostiene que se estaría asistiendo al agotamiento del orden internacional delineado desde Westfalia, lo que se expresaría en la constitución de lo que él denomina Southfalia, es decir, un nuevo sistema internacional definido por el gradual despegue y auge de los poderes del Sur. Si Westfalia estaba marcado por la preferencia hacia el status quo por parte de las potencias dominantes, esta vez, Southfalia parecería estar insatisfecho con la estructura existente, combinando diferentes estrategias orientadas a limitar las opciones de los poderosos y a "incrementar las alternativas autónomas propias" (Tokatlián, 2011: 156). Estos nuevos poderes emergentes,

“...provienen de la periferia, poseen regímenes políticos diversos, sus casas no están plenamente ordenadas, gravitan significativamente en la economía mundial, están descontentos con los equilibrios de fuerza vigentes, tienen altos niveles de desigualdad, despliegan una conducta externa heterodoxa y se encuentran muy inclinados a favor de una repartición de poder en el terreno global" (Tokatlián, 2012:114-115).

Asimismo, estos Estados se caracterizan, además de su ingente actividad en ámbitos multilaterales, por su gran número de habitantes, pluralismo de culturas y un PBI elevado en cifras absolutas, en comparación con otros países de sus respectivas regiones, además de poseer fuerzas armadas fuertes $\mathrm{y}$, en ciertos casos, también armas nucleares (véase Nolte, 2007; y De Sousa, 2007). 
América Latina ha estado igualmente involucrada en los debates sobre las tendencias del mundo emergente, particularmente al considerar el posicionamiento global que va adquiriendo Brasil y, de manera secundaria, Argentina y México. Pero también por la cada vez mayor presencia de actores emergentes foráneos en la región, como lo expresa la relevante presencia de China en su comercio bilateral con varios países, sin olvidar los cada vez más múltiples lazos con Rusia, India, Sudáfrica e incluso Irán. El mundo multipolar está fuertemente presente en la región, poniendo en entredicho el tradicional supuesto de apreciar a este espacio como el "patio trasero" de Estados Unidos. Como señala Tokatlián:

“...la Doctrina Monroe parece resquebrajarse. Una serie de hechos recientes así lo muestran. Crece en la región, y con distintos medios, el despliegue de países como China, Rusia, la India, Sudáfrica e Irán. A estos actores estatales hay que sumar la variedad e intensidad de lazos de actores no gubernamentales (partidos políticos, organizaciones civiles de diversa índole, movimientos antiglobalización, comunidades religiosas, grupos transnacionales criminales, entre otros) con Latinoamérica..." (Tokatlián, 2011: 149).

La presencia China ha sido especialmente relevante, por cuanto se ha transformado en el principal socio comercial de los países de la región y uno de los mayores inversores externos. Según Maihold (2011), el año 2004 representa un punto de inflexión en el dinamismo del relacionamiento entre América Latina y China, expresado en variadas visitas de Estado y en la formulación de intereses comunes en el plano de la cooperación económica, aunque los temas políticos no han estado ajenos a las conversaciones.

Pese a ello, resulta claro que la presencia china no se presenta como un desafío a Estados Unidos y, por lo tanto, no pretende competir ni rivalizar con la potencia norteamericana, seguramente atento a lo que sucede en su antiguo "patio trasero". 
Según señala el académico norteamericano Evan Ellis, las relaciones entre la región y la potencia asiática se concentrarían en cuatro puntos esenciales:

- El abastecimiento de recursos naturales;

- La apertura de nuevos mercados para productos chinos;

- La búsqueda del aislamiento diplomático de Taiwán; y

- La construcción de nuevas asociaciones estratégicas para posicionarse como poder global (En Maihold, 2011: 191-192).

Como se aprecia, si bien con matices, existe un cierto consenso entre los autores en que se asiste a una transición de poder en el mundo, en desmedro de los tradicionales poderes centrales, donde América Latina también está cumpliendo un papel destacado. La disyuntiva está en identificar el posicionamiento que adquirirán los nuevos poderes emergentes y si configurarán un escenario plenamente multipolar, así como el rol que cumplirá la región en esta nueva dinámica geopolítica.

Otro tema que se asoma en las discusiones es si este eventual nuevo escenario será predominante y verdaderamente multilateral y democrático en la toma de decisiones. En esta línea, un tema visible es el progresivo protagonismo que están adquiriendo ciertos foros de corte elitista, como ha sido el relevante papel desempeñado por el foro G-20 ante la última crisis económica y financiera internacional, que ha tendido a dejar en un plano secundario a Naciones Unidas, que con sus 193 miembros representa la instancia más representativa y legítima de la comunidad internacional. O sea, se está desarrollando un profundo debate planteado entre dos términos a primera vista antagónicos en la toma de decisiones internacionales: Eficacia y legitimidad.

Lo anterior pone en evidencia una gradual tendencia a enfrentar los grandes temas actuales mediante un "minilateralismo" (Naím, 2009), antes que a través de un multilateralismo amplio e inclusivo. Este es uno de los grandes temas políticos para la reflexión de los países con vistas al renovado escenario internacional que se está configurando. 
Cabe igualmente agregar la proliferación de nuevos actores no estatales en la política mundial, como son las extensas redes de las organizaciones de la sociedad civil, actores no tradicionales que poseen sus propias estructuras y formas de trabajo en torno a temas tales como la protección del medio ambiente, igualdad de género, asuntos indígenas y desarme y no proliferación, entre otros. En suma, tales organizaciones forman parte de una "conciencia crítica" de la globalización, antes ciertas dinámicas perversas que expresa en su enérgico despliegue a lo largo y ancho del mundo.

Desde luego, tal aparición de nuevos actores ha tenido efectos en el terreno de la seguridad y la defensa. Si el escenario internacional propio del periodo de la Guerra Fría se concibió como una red de relaciones interestatales, la interdependencia ha traído consigo la aparición de nuevos actores susceptibles de identificar con los efectos siniestros de la globalización, relacionados con el ingente desarrollo que expresan las redes del crimen organizado, particularmente en el terreno del narcotráfico, y el terrorismo. Estos renovados desafíos representan una sección importante de las agendas de los gobiernos de la región y el mundo, teniendo efectos incluso en las distintas apreciaciones y percepciones de los países sobre la utilización de los medios militares y de seguridad interior, lo que está teniendo, al mismo tiempo, impacto en los sistemas democráticos y en el resguardo de los derechos humanos.

La institucionalidad internacional ha dado cuenta de estas nuevas realidades de la política internacional, como lo evidencia el dinamismo que expresa el mencionado posicionamiento multilateral de los poderes emergentes a nivel global y regional, en el marco de su actividad en el BRICS e IBSA, entre otros. Pese a lo anterior, las más tradicionales organizaciones multilaterales globales no se han adecuado con la misma rapidez, como ha sido el caso del Consejo de Seguridad de Naciones Unidas, cuya reforma y ampliación aparece todavía estancada, pese a la imperativa necesidad de adecuarlo a los complejos desafíos y amenazas actuales, así como a las nuevas realidades del poder global. Los principales obstáculos provienen de los cinco miembros permanentes, que son renuentes a diluir su influencia en uno de los principales órganos del multilateralismo global (Gill, 2012: 12). 
Además, cabe señalar que tampoco América Latina ha expresado una posición unánime ante estos temas. Por ejemplo, en el marco de las negociaciones intergubernamentales que se han llevado a cabo en Naciones Unidas sobre la reforma del Consejo de Seguridad, Argentina, Colombia y México forman parte del grupo denominado "Unidos por el Consenso", que se opone a la incorporación de nuevos miembros permanentes a dicho órgano; mientras Brasil, que forma parte del G-4 (Junto a Alemania, India y Japón), apunta en último término alcanzar un asiento permanente en el mismo. Alcanzar una posición regional unívoca en la materia es un tema todavía pendiente. El país que cuenta con mayores posibilidades de alcanzar un asiento permanente en el mencionado órgano, como es Brasil, no cuenta con el apoyo unánime de los países de la región, que oscilan entre el pleno apoyo (como es el caso de Chile) y el temor ante eventuales aventuras hegemónicas y disputas por el liderazgo regional (como Argentina y México).

El creciente multipolarismo que se aprecia en el acontecer internacional ha dado lugar a un extenso análisis desde la academia y en el ámbito multilateral. El Informe sobre Desarrollo Humano 2013 del Programa de Naciones Unidas para el Desarrollo (PNUD) está dedicado justamente al "ascenso del sur". Según el documento, hacia el año 2020 se estima que la producción económica combinada de Brasil, China e India superará el total de Canadá, Francia, Alemania, Italia, Reino Unido y Estados Unidos. Gran parte de esta expansión se debería a las nuevas asociaciones de comercio y tecnología al interior del mismo Sur (PNUD, 2013: iv).

El mismo informe señala más adelante que se proyecta que para el año 2050 Brasil, China e India, conjuntamente, representarán el $40 \%$ de la producción mundial, en términos de la paridad del poder adquisitivo. De este modo, el ascenso del sur representaría un nuevo desafío a los principios por los que hasta ahora se han regido las principales instituciones surgidas a partir de la Segunda Guerra Mundial, lo que exigiría "marcos de trabajo más representativos de gobernanza internacional, caracterizados por principios de democracia e igualdad" (PNUD, 2013: 1). 
Se asiste, de tal modo, a un escenario crecientemente equilibrado entre los países tradicionalmente entendidos como parte del Norte y el Sur, con una periferia cada vez más protagónica en los asuntos políticos y económicos mundiales. Sin embargo, esta realidad no ha tenido eco en las tradicionales organizaciones del multilateralismo global. Según señala el citado Informe del PNUD, muchas de las instituciones y principios de la gobernanza internacional actual fueron pensadas para un mundo bastante distinto al actual, una de cuyas consecuencias, "es que en ellos el Sur está subestimado" (PNUD, 2013: 7).

Para la comunidad internacional, resulta un imperativo el reformar y actualizar las instituciones multilaterales para poder resguardar y proporcionar de mejor manera bienes públicos mundiales, entre los cuales se encuentra en un lugar prominente la paz y seguridad internacionales. En esta línea, como se expresará en el siguiente acápite, resultan fundamentales los avances que se puedan hacer a nivel regional, con el objeto de contribuir, de manera conjunta con Naciones Unidas, a la gobernanza y la estabilidad internacional.

La desconcentración del poder, así como la complejidad de los temas que deben enfrentar los países y la comunidad internacional en su conjunto, en el marco del proceso de globalización, han tenido efectos en el desarrollo de regímenes internacionales, en tanto los países se han hecho cada vez menos eficaces para enfrentar por sí mismos las crecientes demandas y desafíos que implica la interdependencia regional e internacional. Ello ha tenido efectos en el terreno de la integración regional que, como proceso, ha vivido un auge en diversas regiones del mundo. Es decir, la globalización, la proliferación de nuevos actores y la dificultad de los tradicionales Estados para satisfacer sus intereses de manera autárquica, han incidido de manera importante en el desarrollo del fenómeno de la integración regional, particularmente desde la perspectiva de la seguridad y la defensa.

En esta línea, Daniel Flemes, Detlef Nolte y Leslie Wehner, plantean que, en el mundo contemporáneo, los riesgos y amenazas en materia de seguridad y defensa son primariamente regionales, más que locales, nacionales o internacionales, por lo que las instituciones regionales están pasando a 
desempeñar un papel central en los temas de paz y seguridad, de conformidad con la Carta de Naciones Unidas (Flemes, Nolte y Wehner, 2011: 112).

La integración, como un mecanismo de socialización y de generación de intereses cruzados, en último término favorece la estabilidad y confianza entre los países, contribuyendo de este modo a la gobernanza global. Esta situación ha estado al centro de instancias como la Unión Africana, la Liga Árabe, la Asociación de Naciones del Sudeste Asiático (ASEAN), la Organización de Cooperación de Shanghai $y$, en el caso del presente trabajo, del Consejo de Defensa Suramericano, cuyo desarrollo da cuenta de un flexible proceso que optimiza la comunicación y el aprendizaje mutuo entre sus miembros, bajo la perspectiva de la defensa. En el fondo, a lo que se apunta, es que en un contexto multipolar y abierto, sólo actuando colectivamente los países pueden hacer valer su voz en el mundo. Esta es la sustancia del siguiente acápite.

\section{b) Multipolarismo e integración regional. Una perspectiva desde América}

\section{Latina}

El heterogéneo sistema internacional y la consecuente reordenación del poder que se aprecia actualmente en el mundo, ha favorecido una creciente red de interdependencia, donde los desafíos y amenazas que se ciernen sobre los países se han complejizado, exigiendo, para su enfrentamiento, de un accionar conjunto y cooperativo entre los Estados. Ello ha supuesto el desarrollo de variadas instancias multilaterales y regímenes internacionales, que tienen como objeto otorgar grados de gobernabilidad en un ambiente altamente descentralizado, que crecientemente avanza hacia la coordinación política en los niveles subregional, regional e internacional.

Tal escenario internacional, determinado por la interdependencia, exige una visión estratégica distinta a la tradicional forma de concebir el poder en virtud de atributos clásicos como el territorio, la población o el poderío militar, siendo la participación en organismos regionales e internacionales una manera de aumentar el prestigio y la legitimidad, actuando los países de un modo concertado y 
solidario, sin dejar de perseguir sus propios objetivos e intereses nacionales. A este respecto, Joseph Tulchin y Ralph Espach sostienen que:

"La interdependencia aumenta los costes de la violencia interestatal y los comportamientos no cooperativos y genera incentivos para la resolución de conflictos por medios pacíficos que no perturben los flujos económicos ni los principios sociales...Los países continúan persiguiendo sus propios intereses y la extensión de su poder, pero sin la mentalidad de suma cero que dominaba con anterioridad el sistema internacional" (Tulchin y Espach, 2004: 28).

En otras palabras, la interdependencia entre los miembros de la sociedad internacional ha implicado notables dificultades para los actores estatales y no estatales para actuar individualmente frente al amplio espectro de demandas y desafíos que lleva aparejado el proceso de globalización (Young, 1997: 273). En tal contexto, la integración regional se ha manifestado vigorosamente como una respuesta a tales circunstancias, en la medida que los Estados buscan estrategias de adaptación a un mundo complejo e interdependiente, de manera de satisfacer de mejor manera sus propios intereses.

En el fondo, como señala Hettne, el regionalismo actual forma parte de una estrategia bifronte respecto de la globalización en la que, por una parte, los gobiernos se asocian para defenderse, pero a la vez, asumen una estrategia ofensiva que les permite posicionarse de mejor manera y participar de los beneficios de la interdependencia global (En Botto, 2015: 24). El profesor argentino Roberto Russell señala, en tal sentido, que:

“...la globalización económica, por las oportunidades y los riesgos que ofrece, influye cada vez más y de manera distinta en la importancia relativa de la región para sus países y, más específicamente, para actores de peso político y económico significativo dentro de cada país. Aparece aquí un evidente 
aunque ambiguo vínculo entre globalización e integración que es preciso explorar" (Russell, 2011: 135).

En el mismo orden de ideas, Francisco Rojas sostiene que "Las regiones se han vuelto un factor clave de las relaciones internacionales. Ahí se desarrollan dinámicas que influyen en los procesos de gobernanza global y allí se reciben diversos impactos de fenómenos globales" (Rojas, 2014: 159). En un similar tenor, Vacas y Rodríguez apuntan que "en los inicios del siglo XXI la integración no es ya una opción ideológica, sino una auténtica necesidad objetiva si se pretende mantener cierto grado de autonomía, de presencia y de influencia en la gobernanza global..." (Vacas y Rodríguez, 2013: 151).

Recogiendo tales argumentos, los ex Presidentes de Brasil y Chile (dos países fuertemente impulsores del establecimiento de la UNASUR y el Consejo de Defensa Suramericano), Luiz Inacio Lula Da Silva y Ricardo Lagos, sostuvieron en una columna publicada en el diario El País de España que:

"América Latina tiene una insólita oportunidad histórica, ya que se encuentra allí donde comienzan a confluir corrientes procedentes del Atlántico y el Pacífico. Pero este desafío actual exige a nuestras comunidades que, en ambos océanos, ahora y no más adelante, modulen mejor su voz" (Da Silva y Lagos, 2014).

Bajo esta perspectiva, la reactivación de la integración regional, que se apreció en América Latina desde fines de los ochenta y con mayor fuerza desde los noventa, puede ser valorada como una estrategia fundamental para facilitar la inserción internacional y la posición negociadora con otras regiones del mundo, bajo la conceptualización del denominado Regionalismo Abierto, que se desarrollará más adelante. Esta idea también estará en la base de sustentación, aunque desde otra perspectiva, del denominado "nuevo regionalismo", que se está desarrollando en el área desde los albores del siglo XXI.

A este panorama cabe agregar la situación de irrelevancia estratégica que usualmente se le ha atribuido a América Latina, así como la pérdida de interés de Estados Unidos en este espacio, estando sus prioridades de seguridad en otras 
áreas del mundo, como es el caso de Medio Oriente y la Península Coreana. Ello, sin dejar de lado el creciente acercamiento chino hacia América Latina, en su búsqueda global por abrir mercados y sectores de inversión a su vasta economía. Como señala Rojas, en este marco se "abre un mayor margen de acción para los países latinoamericanos, el cual se incrementará si la región es capaz de concordar visiones, intereses y cursos de acción para una mejor inserción internacional y para avanzar en su desarrollo nacional y regional" (Rojas, 2014: 161).

En un contexto internacional cada vez más multipolar, el papel que puedan jugar los organismos regionales de integración resulta fundamental para reforzar la proyección internacional y, del mismo modo, los intereses nacionales de los Estados. En tal respecto, cabe rescatar lo planteado por el profesor José Manuel Sobrino, quien define a las organizaciones regionales como aquellas:

“...agrupaciones permanentes formadas principal aunque no exclusivamente por tres o más Estados soberanos pertenecientes a una determinada área regional -geopolíticamente expresada-, entre los que existen vínculos de solidaridad diversa, constituida por acuerdo común entre los mismos, generalmente un tratado y ocasionalmente otro acto internacional, dotadas de unas instituciones comunes encargadas de gestionar los intereses colectivos, para lo cual gozarán de personalidad jurídica internacional y de los medios necesarios para alcanzar los objetivos comunes" (En Vacas y Rodríguez, 2013: 10).

Considerando lo antes señalado, se puede señalar que el poder depende cada vez más de la capacidad de los países de actuar de manera coordinada y con una voz común en la economía global y la política multilateral regional y global, por sobre los tradicionales supuestos sobre los recursos de poder de los Estados, definidos meramente en virtud de la cantidad de armamentos acumulados, el territorio, la población y los recursos. Una cita de Joseph Tulchin y Ralph Espach, resulta especialmente útil en esta línea: 
"Para aquellos países que gozan de escaso poder en sentido realista, como sucede con los latinoamericanos, la participación en las instituciones internacionales difunde el poder y proporciona a los países un escenario para la negociación en donde pueden acrecentar su influencia en lo relativo a la construcción de los valores y reglas institucionales" (Tulchin y Espach, 2004, p. 28-29).

Diversos autores señalan que las tendencias que expresa el sistema internacional evidencian la necesidad de avanzar en la integración regional, como una estrategia de inserción internacional. Por ejemplo, según señala Luis Maira:

"En un mundo de grandes regiones los países por separado, aún los de mayor tamaño como Brasil, no tienen un peso suficiente para influir en la gran discusión del nuevo orden político y económico global. Una América del Sur integrada, en cambio, podría desempeñar con eficacia ese papel" (Maira, 2007: 180181).

Como es posible vislumbrar, lejos de las concepciones autárquicas vigentes en la región a mediados del siglo XX, la integración regional supone, en la actualidad, un instrumento eficaz para que los Estados, trabajando de manera mancomunada, puedan tener una voz en la política y la economía internacionales, incrementando de paso su autonomía y peso en la toma de decisiones a nivel global. O sea, la integración se relaciona con el intento de los Estados por dotarse de ciertos instrumentos políticos que les permitan aprovechar las oportunidades que entrega la globalización, fortaleciendo sus capacidades de negociación en los planos bilateral y multilateral, y favoreciendo, en consecuencia, su proyección internacional.

Bajo esta perspectiva, es posible suponer que la integración no solo se refiere a un proceso mediante el cual los Estados ceden soberanía a favor de una comunidad ampliada, sino como una manera en que los Estados incrementan su 
poder relativo, fortalecen su autonomía, aumentando al mismo tiempo sus atributos soberanos en el plano internacional.

En el contexto cada vez más multipolar que se aprecia en el presente, es posible señalar que América Latina está cada más segura de su posicionamiento internacional, como lo evidencia su relevante presencia en el G-20 (a través de Argentina, Brasil y México) y su cada vez más diversificada agenda exterior, en función del incremento de su peso específico en la política y economía global, mientras, los países europeos todavía pugnan por superar plenamente la crisis económica y financiera, así como enfrentar la actual crisis migratoria y la doquier presente amenaza del terrorismo. Como sostiene Alain Rouquié:

"La apertura del club de los países ricos (G-8) significa, entre otras cosas, que los Estados de América Latina, en su diversidad, se han convertido en socios indispensables para legitimar las concertaciones multilaterales con objeto de mejorar la gobernanza mundial...Pero este nuevo reconocimiento de la madurez de la América Latina emergente no es simplemente una cuestión de prestigio; también ha tenido consecuencias concretas y visibles en materia de autonomía de decisión internacional y de soberanía" (Rouquié, 2011: 114).

Desde luego, este posicionamiento internacional es el reflejo de la actividad particular de ciertos países prominentes, como es el caso de Brasil, pero también es el fruto de la acción concertada de los Estados de la región, en el marco de instancias de integración. De hecho, América Latina "De lejos es el continente con más experiencias de acuerdo de integración regional en su haber" (Botto, 2015: 17), muchos de ellos superpuestos en el tiempo y espacio, cuya sobreoferta ha llevado a diversos autores a señalar que se estaría en presencia de un "spaguetti bowl".

Si bien el camino de la integración regional latinoamericana parece usualmente sinuoso, errático y con tendencias al retroceso y la fragmentación -con discursos altisonantes y derroches de retórica, pero con una resistencia de fondo a ceder 
espacios de soberanía-, no obstante, la vista debe ponerse en los procesos de largo plazo, donde el incremento de la interdependencia parecería positivo. Los diversos obstáculos que ha encontrado la interdependencia económica y, particularmente el comercio intrarregional, han tenido como contrapartida, por ejemplo, una nutrida agenda en el campo de la seguridad y la defensa.

Haciendo un poco de historia, los antecedentes originarios de la integración latinoamericana se pueden encontrar en el Congreso de Panamá de 1826, impulsado por Simón Bolívar ante las tendencias hegemónicas que exhibía Estados Unidos, luego de la adopción de la Doctrina Monroe de 1823, que podría sintetizarse bajo el lema "América para los americanos".

Ya en el siglo XX, el diplomático y académico Gert Rosenthal (1993), distingue tres etapas de la integración latinoamericana, cuales son las etapas voluntarista, revisionista y pragmática. La primera abarca los años cincuenta, sesenta y los primeros años de los setenta, produciéndose a raíz de la realidad de la Postguerra Mundial, y encontrando eco en las interpretaciones de la Comisión Económica para América Latina y el Caribe (CEPAL), que apuntaban a la necesidad de avanzar en la industrialización. Este proceso contó con fuertes barreras proteccionistas y una activa participación estatal, con miras a impulsar el desarrollo de los países de la región.

Así las cosas, desde sus inicios en 1948, la CEPAL, bajo el liderazgo del argentino Raúl Prebisch -acompañado por un grupo de economistas de distintos países de la región, como Celso Furtado de Brasil, Juan Noyola de México, y los chilenos Jorge Ahumada, Aníbal Pinto y Osvaldo Sunkel- propuso una nueva estrategia para el desarrollo de América Latina, llegando a constituirse en la principal escuela de pensamiento acerca del desarrollo económico regional.

En pocas palabras, la crítica estructuralista de la CEPAL acerca del desarrollo latinoamericano, postulaba la existencia de una marcada hegemonía del capitalismo central. En el contexto de la Guerra Fría, realizando una síntesis entre socialismo y capitalismo, la CEPAL proponía que en el progreso técnico estaba la clave para superar el subdesarrollo y la consecuente situación periférica de América Latina. En su etapa estructuralista (1948-1990), desde la CEPAL se sostenía que el capitalismo desarrollado era centrípeto, por cuanto el progreso 
técnico no se propagaba hacia la periferia, lo que redundaba en un deterioro estructural de los términos de intercambio, en desmedro de los intereses de América Latina, cuya producción se basaba en la exportación de productos primarios. De este modo, en la perspectiva de la citada oficina regional de Naciones Unidas, las relaciones internacionales estaban marcadas por la dependencia, con asimetrías abismantes en poder económico y tecnológico, entre el centro desarrollado y una periferia crecientemente pauperizada.

En ese marco definido por la CEPAL, la estrategia fundamental para superar la condición periférica de la región y atenuar las asimetrías entre el centro y la periferia, era la Industrialización por Sustitución de Importaciones (ISI). La búsqueda por ampliar los mercados internos llevaría a la CEPAL a proponer la proyección del modelo ISI a nivel regional. Sobre la base de lo anterior, desde dicha oficina económica se entendía la integración regional como un proceso imprescindible para ampliar los mercados nacionales, en tanto un componente elemental de las políticas de desarrollo que se debían articular a nivel nacional y regional. Bajo este enfoque, sólo a través del desarrollo de un mercado regional ampliado podría mejorarse la competitividad latinoamericana, en el contexto del capitalismo que se desarrollaba en el mundo. La integración, de este modo, se basaba en metas ambiciosas, con un fuerte instrumental institucional.

En esta etapa, los supuestos de la CEPAL se materializaron en el establecimiento de la Asociación Latinoamericana de Libre Comercio (ALALC), establecida en Montevideo el año 1960, con el objeto de establecer un área de libre comercio, que sentara las bases para la gradual creación de un mercado común de alcance regional. Los precarios resultados de la ALALC, que no logró incentivar de manera importante el intercambio regional, unido a las dificultades de avanzar por el camino de la industrialización -nunca se superó la etapa "fácil" de la ISI-, rompiendo con ello la dependencia de los países del centro desarrollado, llevaron a los países del área andina a formar el año 1969 el Pacto Andino, que esta vez contaría con un modelo jurídico e institucional más acabado que su antecesora.

No obstante, los resultados del Pacto tampoco fueron los esperados. No habiendo dinamizado el desarrollo regional, un golpe determinante asestó Chile al retirarse del el año 1976, cuando el país comenzaba a articular un proceso de liberalización 
económica bajo el régimen militar, que se hacía incompatible con el proteccionismo que defendía el proceso regional. Asimismo, a la ALALC y el Pacto Andino, cabría agregar en esta etapa la creación del Mercado Común Centroamericano (MCCA), en el año 1960.

La segunda etapa que distingue Rosenthal es la revisionista, surgida entre los setenta y ochenta a raíz de los magros resultados de las iniciativas regionales de la etapa anterior y de la pérdida de dinamismo del proceso industrializador. Esta etapa está marcada por la puesta en marcha de modelos alternativos por parte de los gobiernos, muchos de los cuales mantenían un corte doctrinario cercano al neoliberalismo o monetarismo. Según este autor, en esta etapa revisionista se postuló el abandono de las metas prefijadas, poniéndose un mayor énfasis en la "integración informal", en vez de compromisos amplios y totalizadores (Rosenthal, 1993: 78).

En tal contexto, desde varios gobiernos de la región se plantearon una serie de críticas sobre el tradicional pensamiento cepalino sobre la integración regional. Por ejemplo, se sostuvo que el proteccionismo y el sesgo antiexportador, propio de los años cincuenta y sesenta, sólo fue apoyado por los sectores industriales y obreros; que si bien se disminuyeron las importaciones de bienes de consumo, simultáneamente aumentó la importación de materias primas y bienes de capital, incrementándose en consecuencia la dependencia de las importaciones; la falta de competencia en el sector industrial; la gran inflación que se desencadenó bajo el modelo ISI y, desde luego, los escasos avances apreciados en materia de integración latinoamericana (véase Corbo, 1988).

En ese ambiente es que los países latinoamericanos impulsan la formalización de la Asociación Latinoamericana de Integración (ALADI), establecida a través del Tratado de Montevideo en 1980. Este documento se caracteriza por su aproximación pragmática y flexible hacia la integración, no imponiendo metas a los Estados, más allá de los compromisos que libremente acepte cada uno de ellos.

En la conceptualización de Rosenthal, la última etapa es la pragmática, susceptible de enmarcar en la década de los noventa y en los cambios que acontecían a nivel internacional, como eran la creciente globalización de la economía; una gradual tendencia hacia la convergencia entre los países de la 
región en materia de política económica; y la tendencia hacia regímenes políticos plurales y democráticos (Rosenthal, 1993: 81).

En este cuadro es que surge el MERCOSUR en 1991, impulsado principalmente por el acercamiento entre Brasil y Argentina, así como se transforma el Pacto Andino en la Comunidad Andina, el año 1996. La integración entonces pasó a entenderse como una estrategia de inserción internacional de los países de la región, favoreciendo la articulación productiva y la interacción creativa entre los agentes públicos y privados (Rosenthal, 1993: 82). De tal modo, en un nuevo contexto regional marcado por la desregulación y las privatizaciones y en un contexto internacional determinado por el proceso de globalización, hacia la década de los noventa la CEPAL actualizó su reflexión. Es la denominada etapa neoestructuralista (desde 1990 en adelante), que si bien mantiene importantes continuidades con la fase estructuralista, de todos modos impregna la reflexión con relevantes innovaciones.

El documento clave para entender este cambio es Transformación productiva con equidad, del año 1990. En este texto, entre otros importantes argumentos, la CEPAL impulsa la inserción internacional de América Latina y el Caribe, sobre la base de los postulados del Regionalismo Abierto. Ello requerirá como condición el fomento de una competitividad auténtica de la región, basada en la capacidad productiva, la calificación del capital humano y la innovación tecnológica, en contraposición a la denominada competitividad espuria, sustentada en ventajas salariales, cambiarias y recursos naturales (Bielschowsky, 2009) .

En dicho contexto, la CEPAL comienza a promover una nueva conceptualización sobre la integración, más pragmática y liberal que la "integración cerrada" impulsada hacia mediados del siglo XX. Surgía de este modo el señalado Regionalismo Abierto, entendido como aquel:

“...proceso de creciente interdependencia económica a nivel regional, impulsado tanto por acuerdos preferenciales de integración como por otras políticas en un contexto de apertura y desreglamentación, con el objeto de aumentar la competitividad de los países de la región y de constituir, en lo posible, un cimiento 
para una economía internacional más abierta y transparente" (CEPAL, 1994: 8).

Complementando y actualizando la clasificación planteada por Rosenthal, cabe señalar que hacia principios del siglo XXI se asiste a una nueva etapa de la integración regional, caracterizada por un fuerte contenido político y social, antes que económico y comercial, el que ha dado lugar a una serie de nuevas conceptualizaciones, como aquellas relativas al denominado "nuevo regionalismo". En este marco es que nace la UNASUR y el ALBA -sin olvidar el establecimiento, el año 2011, de la Comunidad de Estados Latinoamericanos y Caribeños (CELAC)-, instancias que han llevado a algunos autores a sostener que se estaría en presencia de un regionalismo de carácter postliberal, poshegemónico o sudamericano (véase Sanahuja, 2008; Botto, 2015).

Además, aparecen diversas apreciaciones sobre el tipo de integración regional a seguir, manifestadas en las distintas visiones acerca de la inserción de la región en el mundo (Malamud, 2009). Según Briceño (2013), ello se ha traducido en la atomización subregional de la integración en torno a tres ejes: aperturista, revisionista y anti-sistémico, representados en los bloques de la Alianza del Pacífico -de corte más bien economicista y liberal-, MERCOSUR -que avanza fuertemente en los temas políticos y sociales, ante los obstáculos que encuentra en el terreno comercial- y la Alianza Bolivariana de los Pueblos de Nuestra América (ALBA), bajo un signo fuertemente antiimperialista y antihegemónico.

Este nuevo proceso del regionalismo latinoamericano, con un énfasis político antes que comercial, deriva del relativo agotamiento que evidencia el Regionalismo Abierto surgido luego del fin de la Guerra Fría, que se centraba de manera acentuada en los aspectos relacionados con la liberalización comercial intrarregional. Es decir, dando muestras de debilidad en los albores del nuevo siglo, el Regionalismo Abierto sufrió el embate de las fracturas ideológicas que vivió la región con el ascenso de gobiernos asociados al Socialismo del siglo XXI y el surgimiento de instancias como la UNASUR y el ALBA, con un contenido político que apunta a la búsqueda de una mayor autonomía de la región, donde los temas relacionados con la seguridad y defensa están en un rol destacado, 
como lo evidencia el establecimiento y desarrollo del Consejo de Defensa Suramericano.

Sanahuja y Verdes-Montenegro plantean al respecto que "...la política exterior parece ser uno de los rasgos distintivos del regionalismo post-liberal que, asimismo, frente al regionalismo abierto, adopta un enfoque multidimensional que va más allá de la dimensión económica" (Sanahuja y Verdes-Montenegro, 2014: 489). En los hechos, respecto del Regionalismo Abierto, esta nueva agenda de la integración regional sigue ciertamente un camino distinto, por cuanto:

“...los temas económicos quedaron en la trastienda para no obstaculizar la nueva agenda de la integración de América Latina, mucho más ambiciosa y extensa que la vieja. Ella incluye, entre otros temas, la interconectividad, la cultura, la ciencia y la tecnología, el vínculo entre los pueblos, la cooperación en temas de seguridad y de defensa, la búsqueda de acuerdos y la coordinación de políticas para resolver problemas o crisis regionales...Los problemas y conflictos están a la orden del día, pero también pesan numerosas fuerzas de moderación, históricas y nuevas" (Russell, 2011: 127-128).

De tal modo, con el visible liderazgo brasileño, aunque secundado en los inicios del nuevo siglo por Venezuela -que al momento en que se escriben estas líneas se encuentra en una grave crisis económica e institucional- la integración regional en América Latina avanza de manera predominante en el contexto de América del Sur-perdiendo terreno México, pese a su actividad en el marco de la Alianza del Pacífico-, redefiniendo los debates sobre la integración latinoamericana y su vínculo con la seguridad regional, ante las muestras de agotamiento que demuestra el esquema estratégico hemisférico.

La integración sudamericana cobrará fuerza particularmente a partir de la creación de un Área de Libre Comercio de Suramérica (ALCSA), impulsada desde Brasil, buscando la convergencia entre el Mercosur y la Comunidad Andina de Naciones (CAN). Este proceso ganaría fuerza especialmente tras la Presidencia de 
Fernando Henrique Cardoso en Brasil, hacia finales de los noventa (Sanahuja y Verdes-Montenegro, 2014: 494). Tal dinámica decantará posteriormente en la Cumbre Suramericana de Brasilia, de mayo de 2008, donde se adoptaría el Tratado Constitutivo de la UNASUR. En esta instancia, el gigante sudamericano promovería la creación del Consejo de Defensa Suramericano, que en sus primeros momentos contó con la oposición frontal de Colombia, ante la pretensión venezolana de otorgar estatuto de "beligerantes" a los miembros de las FARC.

Refiriéndose a las últimas tendencias que expresa la integración regional, se ha planteado desde diversos sectores una suerte de sobreoferta en las propuestas de integración, muchas veces caracterizada como un spaghetti bowl, que ha desembocado, entre otras consecuencias, en pérdida de recursos, dificultades de seguimiento por parte de los países, falta de coordinación, superposición y duplicación de esfuerzos.

Asimismo, en su momento -aproximadamente el año 2015- se desarrolló un profundo debate académico y político, respecto de una eventual fractura en dos de la región de América Latina. Un bloque que colindaba con el Atlántico, representado por Brasil, Argentina y Venezuela, desconfiaba de la globalización, otorgaba al Estado un papel de alta relevancia en la economía y se presentaba hostil hacia Washington. Por otro lado, ciertos países del Pacífico, como México, Perú, Chile y Colombia, promovían el libre comercio y la apertura de los mercados, manteniendo estrechos lazos con Estados Unidos. ${ }^{5}$ Sobre el particular, en 2011 Roberto Russell señalaba que:

"Colombia, Chile, México y Perú han seguido apoyando el regionalismo abierto como un complemento a sus tratados de libre comercio con el mundo, mientras que la Venezuela de Chávez y algunos de sus gobiernos aliados en el ALBA proclaman un regionalismo que retoma las banderas de la unión latinoamericana

\footnotetext{
${ }^{5}$ Véase la columna aparecida en The Wall Street Journal "La historia económica de dos Latinoaméricas". Disponible

en http://lat.wsj.com/articles/SB10001424052702303933104579303101958176612 Recuperado en agosto de 2015.
} 
en clave antiimperialista y anticapitalista, en claro contraste con el de los países mencionados" (Russell, 2011:136).

Sin embargo, esta discusión ha perdido toda fuerza, a partir de los últimos cambios políticos que se han sucedido en la región, que han llevado a que los debates se orienten hacia un supuesto "giro hacia la derecha" de los gobiernos, marcado por la salida de gobiernos de corte progresista, envueltos en graves casos de corrupción. Ello ha sido particularmente notable para el país que debiera constituirse como el líder natural de la integración regional, es decir, Brasil, cuyos problemas internos han dejado en un plano secundario la agenda de la política exterior orquestada desde Itamaraty.

Este proceso político regional, que arrancó con la victoria de Mauricio Macri en Argentina en noviembre de 2015, luego de 12 años de gobiernos kirchneristas, va acompañado por un nuevo ciclo económico marcado por la desaceleración -cuya principal causa es la caída del precio internacional de las materias primas, como es el caso del petróleo-, el desgaste de los "gobiernos largos" y personalistas, así como por demandas ciudadanas por mayor transparencia y rendición de cuentas. ${ }^{6}$

Sin perjuicio de lo anterior, este "giro a la derecha" no ha implicado la generación de un entorno plenamente armónico entre los países de la región. Las divisiones que se aprecian actualmente han sido particularmente visibles con la suspensión, en agosto de 2017, de Venezuela del MERCOSUR. Las críticas a este país fueron particularmente ilustrativas desde el gobierno argentino de Mauricio Macri, quien ya en agosto de 2016 había señalado que Venezuela no cumplía con los requisitos para ser un miembro pleno de dicha instancia, al mismo tiempo que planteaba que su administración tiene "un compromiso absoluto con el respeto de

\footnotetext{
${ }^{6}$ Un interesante análisis al respecto, puede verse en Zovatto (2016). También véase la nota de prensa "BBC: Cómo queda el mapa político de América Latina con el impeachment a Dilma Rousseff en Brasil", 13 mayo 2016. Disponible en http://www.latercera.com/noticia/bbc-como-queda-el-mapa-politico-de-america-latina-conel-impeachment-a-dilma-rousseff-en-brasil/ Recuperado en mayo de 2016; y "How the left blew it in Latin America", 21 abril 2016. Disponible en http://www.miamiherald.com/opinion/op-ed/article73237642.html Recuperado en abril de 2016.
} 
los derechos humanos y lo que está pasando en Venezuela es un desastre". ${ }^{7}$ Las divisiones también han sido visibles en la crisis que actualmente afecta a la UNASUR, donde los gobiernos de Argentina, Brasil, Colombia, Chile, Paraguay y Perú, en abril de 2018, decidieron suspender su participación en las distintas instancias del esquema hasta que éste regularice su funcionamiento, considerando la parálisis administrativa derivada de las dificultades de consensuar un nuevo Secretario General, tras la salida de Ernesto Samper.

Considerando lo antes señalado, respecto a una eventual fractura en la región, Russell utiliza el concepto de "unión fragmentaria", para dar cuenta de la "integración realmente existente en América Latina", caracterizada aún "como una región todavía débilmente vertebrada en la que intervienen poderosas fuerzas de unión y de separación", pese a que la tendencia general se inclina hacia la convergencia y al avance pragmático. En efecto, según Russell,

“...la integración tropieza o retrocede pero la región, o partes de ella, se hacen más interdependientes. Así, poco a poco se avanza en la vinculación física, la relación entre las Fuerzas Armadas de muchos países alcanza niveles de cooperación inéditos y sorprendentes, las sociedades encuentran formas más intensas de contacto a través de las fronteras $y$, por consiguiente, aumenta el espacio de los intereses comunes y el conocimiento mutuo...Fragmentos de unidad que surcan las fronteras de los países muestran que el proceso de regionalización tiene muchas caras y que está vivo. Múltiples actores estatales y privados contribuyen día a día a darle fluidez y van vertebrando un conjunto fenomenal de nuevos vínculos. No es el ALCA, ni el sueño bolivariano, ni un remedo de la Unión Europea. Mucho más modesto en sus alcances y menos perceptible, este proceso de

\footnotetext{
${ }^{7}$ Veáse la nota de prensa "Macri: Venezuela es un desastre y no puede presidir el MERCOSUR". Diario Estrategia, 11 agosto 2016. Disponible en http://www.estrategia.cl/12909/Titulo Revisado en agosto de 2016.
} 
regionalización seguirá, al igual que la globalización, una marcha ascendente" (Russell, 2011: 137-138).

Como es posible observar, pese a los modestos resultados y a lo sinuoso que puede aparecer el camino de la integración regional sudamericana, incluso con muestras de retroceso, lo cierto es que visto en el largo plazo, el proceso es ascendente. En virtud de lo señalado hasta aquí, asumir una perspectiva pesimista sobre la integración regional, haciendo hincapié en los fallos y en las demostraciones de fragmentación, parece poco útil para los intereses y objetivos de los países, por cuanto en el contexto multipolar actual, el poder depende cada vez más de la capacidad de los países de actuar de manera coordinada y con una voz común en la economía global y la política multilateral. Estos son los supuestos basales que han seguido los países para establecer y dar paulatinamente contenido a la UNASUR y al CDS.

Como se verá más adelante, el proceso de constitución de la UNASUR y, en su marco, del CDS, como organismo sectorial encargado del seguimiento e impulso de la cooperación en el plano de la defensa, es "fruto de una renovada política regional intra-suramericana $\mathrm{y}$, al mismo tiempo, producto de una incipiente identidad propia como región en el sistema internacional" (Forti, 2012: 289).

Pese a las muestras de fractura regional, los actores tienden a moverse, más allá de lo aparente, hacia el sentido de la moderación y la convergencia. La polarización pierde fuerza. $Y$ tampoco Estados Unidos se muestra particularmente preocupado por atizar las divisiones, gastando sus energías en otras zonas del mundo más preocupantes desde el punto de vista de su seguridad nacional, cuando no en asuntos latinoamericanos que le afectan directamente en el plano de la seguridad pública, como son el crimen organizado, particularmente el relacionado con el narcotráfico y las migraciones irregulares. 


\section{4.- El contexto regional: democracia y paz en América del Sur}

En el ámbito de la disciplina de las Relaciones Internacionales, la teoría de la "paz democrática" ha tenido una fuerte influencia y numerosos adeptos. Según este cuerpo de ideas, el comportamiento internacional de los Estados sería una proyección de la política interna. Es decir, existiría una cierta correspondencia entre el régimen político doméstico y la prevención de los conflictos armados, en tanto los países democráticos no irían a la guerra entre sí. Pese a ello, lo anterior no obstaría para que los países con este régimen político manifiesten un fuerte belicismo hacia aquellos no liberales, cuestión que tendría un cierto sustento en la experiencia histórica (Doyle, 1983).

Considerando lo anterior, este capítulo aborda las características de la democracia en América Latina, haciendo hincapié en el espacio sudamericano -donde se concentra la presente investigación- y sus efectos en el ámbito de la seguridad regional. En tal sentido, se pone un especial énfasis en la naturaleza de las relaciones civiles-militares, donde se aprecia una mayoritaria tendencia hacia la consolidación de la supremacía civil, en el marco de contextos democráticos que se han mostrado propicios para la paz y la estabilidad regional. En tal sentido, se plantea que si bien aún persisten tareas pendientes en materia de consolidación democrática, de todos modos tales regímenes han propiciado un entorno donde predomina la paz y la estabilidad interestatal, siendo posible caracterizarla como una Zona de Paz. Como se verá más adelante, la región sería un buen ejemplo de la positiva correlación existente entre paz y democracia.

\section{a) América del Sur como Zona de Paz, una mirada histórica}

La guerra interestatal ha estado presente en distintas etapas de la historia sudamericana. Siguiendo la tipología de Kalevi Holsti (1996), Nicolás Terradas plantea que, en una primera etapa, entre 1810 y fines del siglo XIX, la región puede ser catalogada como una "zona de guerra" o "zona de conflicto", donde los hechos bélicos fueron un fenómeno recurrente, teniendo como base consideraciones territoriales y limítrofes, en un contexto histórico definido por la construcción de las nacientes repúblicas. 
En ese entonces, se extendía en la región una suerte de rivalidad entre diversas opciones acerca de las relaciones entre los países y el lugar de Estados Unidos, que se plasmó en el enfrentamiento entre una concepción americanista, de corte hemisférico, promovida desde la potencia norteamericana bajo la guía de la doctrina Monroe de 1823, enmarcada en un mundo todavía dominado por Europa, y otra idea latinoamericanista, impulsada por Simón Bolivar, plasmada en el Congreso de Panamá.

En esa centuria, especialmente relevante es el difícil proceso de construcción del Estado-nación en América Latina que, como parte de un proyecto oligárquico de corte liberal, se desarrolló en un marco de acentuadas rivalidades geopolíticas derivadas de las dificultades de definición de las fronteras, luego de las luchas de independencia. Pese al extenso tiempo transcurrido, tales rivalidades todavía tienen efectos en la región, tendiendo a obstaculizar los procesos de integración en desarrollo. En la práctica, el siglo XIX estuvo marcado por una serie de pugnas, que motivaron, entre otras, la Guerra Cisplatina, 1825-1828 (Argentina, Brasil y Uruguay); la Guerra del Río de La Plata, 1836-1851 (Argentina, Brasil, Uruguay, Gran Bretaña y Francia); la Guerra de la Triple Alianza, 1864-1870 (Argentina, Brasil, Paraguay y Uruguay); y la Guerra del Pacífico, 1879-1883 (Bolivia, Chile y Perú).

En una segunda etapa, entre los años 1883 y 1980 aproximadamente, la región podría definirse como una "zona de no guerra" o de "paz negativa", donde la ausencia de guerra se mantuvo de manera frágil sólo gracias a la presencia de Estados satisfechos con el status quo, pero en la cual la posibilidad de retroceso a una "zona de conflicto" seguía latente. En este período se desarrollaron, por ejemplo, la Guerra del Chaco, 1932-1935 (Bolivia y Paraguay); de Leticia, 19321933 (Colombia y Perú); y Zarumilla-Marañón, 1941 (Ecuador y Perú), sin dejar de mencionar la Guerra de las Malvinas entre Argentina y Reino Unido (1982) (véase Terradas, 2009).

Este trabajo se enmarca en una tercera etapa, susceptible de definir a partir de los procesos de democratización que vivieron varios países de la región, desde mediados de la década de los ochenta. Dichos procesos de transición hacia la democracia estuvieron acompañados por el desarrollo de esquemas de 
integración regionales, como es el caso del MERCOSUR, que devinieron a la región como una zona posible de caracterizar como de "paz positiva" o de "paz estable", marcada por el creciente desarrollo de una comunidad de seguridad, donde se hace improbable la solución de los conflictos internacionales mediante el uso de la fuerza. En coherencia con lo antes planteado, Samuel Alves sostiene que:

"El inicio de las transiciones de los regímenes autoritarios en los países suramericanos se reflexionó también en el ambiente subregional y alteró las relaciones externas de estos países. Rasgos de sospechas, más o menos alimentados por los regímenes autoritarios, fueron paulatinamente sustituidos por una nueva fase de relacionamiento recíproco, inflexión que ha estrechado los lazos y que ha alejado de la región conflictos de naturaleza bélica" (Alves, 2012: 221).

Complementando el argumento anterior, Pablo Celi señala que, en tal contexto:

"Los problemas y los paradigmas de seguridad devienen multidimensionales y la dimensión militar de la defensa se transforma en medio de la fragmentación del sistema estratégico mundial en subsistemas regionales y con el aparecimiento de nuevos complejos de seguridad y dinámicas militares regionalizadas. Este contexto global incide en la actual tendencia suramericana a afirmar su propia perspectiva en los asuntos de seguridad y defensa" (Celi, 2012:464).

Tal proceso va de la mano de una tendencia creciente a que la relación entre integración y seguridad se desplace desde el ámbito hemisférico al subregional, cobrando fuerza este proceso primero en el Cono Sur, con el dinamismo que expresa el MERCOSUR en sus primeros años, aunque luego se proyecta o derrama al plano sudamericano, con la fuerza que adquiere la UNASUR y, en su 
contexto, el CDS, apreciado como un instrumento para afianzar la autonomía de la región en un mundo con fuertes atributos de multipolaridad.

Ello se concatena con la paulatina separación y crítica de ciertos países de la región, predominantemente aquellos vinculados con el eje ALBA, al esquema hemisférico de seguridad, apreciado como un instrumento de dominio americano. En esta línea, Celi señala que:

"Cuando los procesos de reestructuración de las relaciones regionales se impulsan desde los realineamientos políticos en los países del área y las nuevas tendencias de la integración, se ahonda el distanciamiento de la visión hemisférica frente a las aproximaciones y acuerdos a nivel suramericano, fundamentalmente en torno a UNASUR, estimuladas, en el campo de la seguridad regional, con la conformación del Consejo de Defensa Suramericano" (Celi, 2012: 465).

En consecuencia, desde mediados de la década de los ochenta, y con más fuerza en la de los noventa, así como el sistema internacional estuvo sometido a fuertes cambios -ligados al fin de la Guerra Fría y el derrumbe del bloque soviético-, la región de América Latina, particularmente América del Sur, vivió cambios de trascendencia, vinculados con el restablecimiento de los regímenes democráticos y el desafío de reestructurar el rol de las fuerzas armadas y las instituciones políticas, en el marco de lo que desde la politología se denominó la "tercera ola democrática". En ese momento, la región experimentaba su propio Fin de la Historia. Si la seguridad es un asunto esencialmente subjetivo y, por lo tanto, no necesariamente vinculado con una amenaza real, lo cierto es que estrechamente vinculado con los procesos de transición democrática en la región, se produjo otro proceso político mediante el cual se comenzó a configurar una nueva apreciación intersubjetiva en el campo estratégico, donde los países vecinos comenzaron a apreciarse como socios para un objetivo común de paz y desarrollo, antes que como competidores y fuentes de amenazas y conflictos. Tales sucesos, 
relacionados con la recuperación democrática y sus efectos para la paz regional, forman parte del siguiente apartado.

\section{b) El predominio de la democracia en América del Sur}

Según señalan Fukuyama y Matfess, el desarrollo de la democracia no constituye un proceso lineal y ascendente, tal cual lo evidencian varios países de África, como es el caso de Etiopía y Ruanda (véase Fukuyama y Matfess, 2016). América Latina no ha escapado de esta compleja situación. A este respecto, Mainwaring y Scully sostienen que la construcción de las democracias ha sido un proceso particularmente difícil en esta región, así como en la mayoría de las otras democratizaciones de la "tercera ola". Según estos autores, en "numerosos países latinoamericanos, la calidad de la democracia sigue siendo deficiente, con una protección inadecuada de los derechos, y mecanismos débiles de rendición de cuentas del gobierno" (Mainwaring y Scully, 2008). La democracia ha sido un régimen político difícil de construir y consolidar, teniendo resultados dispares a lo largo de la región.

Pese a ello, Alain Rouquié destaca que nunca en su historia la región había tenido tantos gobiernos democráticos y durante tanto tiempo. Según este autor:

"La democracia representativa parece haberse arraigado hasta en países sin previa experiencia en este tipo de sistema político (como es el caso de naciones tan diferentes como Paraguay, El Salvador o México), para no hablar de los Estados que la habían ejercido solo de forma intermitente en el transcurso del siglo $X X$ (como Argentina, Brasil o Bolivia, que fueron «democracias esporádicas»). Este cuarto de siglo de democracia refleja, a la vez, la consolidación institucional y los progresos de la ciudadanía, aun cuando la calidad del pluralismo representativo dista mucho de ser uniforme y varias amenazas se ciernen sobre su evolución futura" (Rouquié, 2011:112). 
Actualmente, en América Latina en general, existe un amplio abanico de democracias, con distintos niveles de consolidación e institucionalización, desde experiencias como la de Haití, que tras el retiro de la Misión de Estabilización de Naciones Unidas (MINUSTAH) y el establecimiento de la Misión para el Apoyo a la Justicia (MINUJUSTH), se encuentra en pleno proceso de construcción del Estado de Derecho, hasta países con una dilatada trayectoria democrática, como son los casos de Chile y Costa Rica.

La performance del Estado ha sido igualmente un tema complejo en las democracias de la región. Según Mainwaring y Scully, un Estado eficaz es importante para la calidad de la democracia, por cuanto éste debe proteger a los ciudadanos, apoyar sus derechos, y supervisar que las elecciones sean libres y justas. Asimismo, plantean que un Estado efectivo es a la par decisivo para el desarrollo, proporcionando una educación pública adecuada, regulando la actividad económica, creando una infraestructura apta para las actividades comerciales y de producción y combatiendo la corrupción, entre otros relevantes asuntos. No obstante, en la mayoría de los países de América Latina el Estado es deficiente, predominando sistemas legales precarios y corruptos. Además, en varios países la capacidad reguladora del Estado es deficiente y la inversión pública en infraestructura es débil (Mainwaring y Scully, 2008: 133-134).

El presidencialismo ha tenido en América Latina resultados dispares, sin perjuicio del contexto pacífico que se aprecia en la región, bajo el punto de vista del conflicto interestatal. Ha sido relativamente exitoso en el caso chileno, pero ha estado marcado por numerosos problemas en otros países, donde ha dado lugar a líderes que se podrían catalogar como neo-populistas, con Alberto Fujimori, Carlos Menem, Hugo Chávez (Vilas, 2004), y últimamente Nicolás Maduro, como preclaros aunque muy diversos ejemplos.

Un régimen neo-populista (al igual que su versión originaria de mediados del siglo $X X)$ se caracteriza por la relación directa entre el líder, con fuertes atributos carismáticos, y la masa. Esta relación directa socava las instituciones tradicionales de la democracia, en tanto supone el debilitamiento de los partidos políticos y otras instituciones propias de un régimen poliárquico, al tiempo que genera, con diversos grados de intensidad en cada caso, polarización política en el electorado. 
De hecho, las crisis institucionales forman parte importante de tales gobiernos. En el campo económico, las políticas económicas de este tipo de regímenes usualmente sacrifican la estabilidad macroeconómica por resultados políticos y sociales (De la Torre y Arnson, 2013). A ello han contribuido las profundas desigualdades sociales y económicas que perviven en la región de América Latina, uno de los continentes más desiguales del mundo.

Michael Conniff plantea que este nuevo tipo de populismo contiene muchas de las características de la versión original -como fueron los gobiernos de Juan Domingo Perón en Argentina y Getulio Vargas en Brasil-, tales como los continuos llamados al sentimiento nacionalista, el liderazgo carismático, campañas publicitarias de masa, promesas de reforma y evocación de los intereses del pueblo; pero tiene ciertas diferencias, particularmente en el abandono, por parte de muchos de estos nuevos líderes, de las políticas económicas de intervención y control (Conniff, 2003:34). En esta línea, podría considerarse a Chávez y en cierta medida a Maduro en Venezuela, como líderes más cercanos a la versión tradicional del populismo, más cercanos a un activo rol del Estado en la sociedad. Los profesores Steven Levitski y Lucan Way (2004), han acuñado el término "autoritarismo competitivo" para calificar este tipo de regímenes, que se encuentran a medio camino entre la democracia competitiva y la dictadura.

La manera en que se ejerce este liderazgo ha dado lugar a un tipo de sistema político que Guillermo O'Donnell calificó en su momento como "democracia delegativa", donde predomina una escasa densidad institucional, desconfianza hacia el aparato público, sistemas de partidos poco institucionalizados -con la presencia de outsiders políticos antipartidos-, así como débiles mecanismos de accountability horizontal (véase O'Donnell, 2004). Según este autor, estas nuevas democracias:

"...se basan en la premisa de que quien quiera gane las elecciones presidenciales tiene en consecuencia el derecho a gobernar como le parezca conveniente, limitado sólo por la dura realidad de que existen relaciones de poder y por un mandato limitado constitucionalmente" (en Pérez-Liñán, 2009: 328). 
En este marco general, el tema de la institucionalidad democrática resulta particularmente relevante, especialmente considerando la creciente desconfianza y crítica hacia las tradicionales instituciones políticas y ante un cada vez mayor empoderamiento ciudadano derivado, entre otros elementos, del auge de las clases medias, una población cada vez más educada y demandante, así como del desarrollo de las tecnologías de la información y, consecuentemente, de las redes sociales.

Lo anterior es particularmente importante en relación con los sistemas de partidos, un componente fundamental de la democracia. A este respecto, Mainwaring y Scully sostienen que los sistemas de partidos institucionalizados constituyen un rasgo fundamental para la estabilidad de la democracia, al dotar de una estructura a la política en el terreno electoral y en el poder legislativo. Asimismo, los partidos son los principales competidores electorales durante un período de tiempo, permanencia que genera una cierta capacidad de predicción respecto del comportamiento de los actores políticos. En suma, en un contexto de estas características, según tales autores, es más difícil para los outsiders políticos llegar al poder (Mainwaring y Scully, 2008: 137).

En el marco de la presente investigación, es particularmente relevante destacar que este especial tipo de presidencialismo se relaciona directamente con la actitud externa de los países, en tanto cada líder "impone su toque personal dificultando el uso del poder y facilitando, al mismo tiempo, el estallido de crisis diplomáticas..." (Barroso, 2016: 20). O sea, tales regímenes tienen efectos en el campo de las relaciones vecinales, por cuanto son usuales portadores de lenguajes nacionalistas, al que no dudan en echar mano a fin de concitar apoyo interno a sus políticas.

La consolidación de la democracia es todavía un tema pendiente en varios países de la región. No obstante, con todos sus problemas, estas débiles democracias han estado enmarcadas en un entorno regional estable y pacífico desde el punto de vista de los conflictos bélicos, pese a que usualmente los líderes neopopulistas causen severas tensiones en las relaciones interestatales, como fue caso de la crisis protagonizada entre Venezuela y Colombia en 2008, o entre Bolivia y Chile 
en diversas ocasiones, pero especialmente durante 2017, cuando el Presidente boliviano Evo Morales agudizó su lenguaje anti-chileno, basado en la pretensión marítima altiplánica.

Sin embargo, es necesario señalar que tales turbulencias son sólo parte de la escenografía de la política latinoamericana, pero no rompen la tendencia estructural de la región hacia la paz. De hecho, el contexto regional ha sido profusamente caracterizado como una Zona de Paz, tanto desde el mundo académico como desde el contexto de la política multilateral. Estos temas son el centro de la siguiente sección, enfocados bajo el prisma de las relaciones entre civiles y militares.

\section{c) Una mirada desde las relaciones civiles-militares. Sus efectos en la paz regional}

Teniendo como base todos los aspectos enunciados anteriormente respecto de la performance de la democracia en la región, una manera de analizar la realidad política latinoamericana es bajo el prisma de las relaciones civiles-militares, cuya normalización, como sostiene Carlos Huneeus (1990:49), constituye una de las bases de la democracia. Ello es relevante, primordialmente al considerar que las democracias latinoamericanas están marcadas por las inestabilidades y las crisis políticas, derivadas de los continuos conflictos entre el ejecutivo y el legislativo y/o protestas populares, pero en las cuales ha disminuido el número de intervenciones militares.

En esta línea, según señala Aníbal Pérez-Liñán, el análisis de los sistemas políticos de la región parece indicar que los incentivos que se les presentaban a los militares en la mayoría de los países en América Latina en la década del sesenta y setenta han cambiado de manera significativa, siendo las razones fundamentales de esta transformación los cambios acontecidos en el contexto internacional, así como el proceso de aprendizaje que desencadenaron los pasados regímenes dictatoriales, entre las élites civiles y militares (Pérez-Liñán, 2009: 77-81). 
Es decir, las crisis políticas que viven las democracias de la región no comprometen la estabilidad de los regímenes democráticos, aunque son letales para los gobiernos democráticos (Pérez-Liñán, 2009: 321). Luego de la participación directa de las fuerzas armadas en la conducción política de varios países latinoamericanos, junto con los procesos de transición que se vivieron desde mediados de los ochenta, los desafíos que se han debido enfrentar en este ámbito se relacionan ahora con el modo de reestructurar y redefinir las funciones militares en un marco democrático y en un contexto internacional marcado por el fin de la Guerra Fría, así como una región definida como una Zona de Paz.

En los hechos, los procesos de transición política a la democracia impactaron fuertemente en la problemática de la defensa, donde la construcción paulatina de una nueva relación civil-militar se manifestó, entre otros aspectos, en la limitación de la participación de las fuerzas armadas en política, con el objeto de asegurar la supremacía civil y, particularmente, en que autoridades civiles asumieran progresivamente la conducción de los Ministerios de Defensa. Cabe destacar a este respecto que una tendencia ciertamente inversa se aprecia en la actualidad en Venezuela, donde el gobierno de Maduro ha ido cultivando una cercana relación con las fuerzas armadas, mediante el aumento de sueldos y la incorporación de militares en puestos claves del gobierno, ${ }^{8}$ como es el caso, entre otros, del General Vladimir Padrino López, actual Ministro de Defensa. ${ }^{9}$

Aunque de manera todavía moderada, Bolivia ha seguido un camino ciertamente similar, expresado, por ejemplo, en una estrecha relación entre el Presidente Evo Morales y el ejército de ese país, institución que incluso le compuso una marcha en su honor, donde se resalta su origen indígena y posición antiimperialista. La siguiente estrofa resulta particularmente esclarecedora:

\footnotetext{
${ }^{8}$ Véase el artículo de prensa "Polimilitarización: la apuesta de Maduro que sigue el modelo de Pinochet”. Disponible en http://www.elmostrador.cl/noticias/pais/2014/11/19/polimitarizacion-la-apuesta-demaduro-que-sigue-el-modelo-de-pinochet/ Recuperado en julio de 2015.

${ }^{9}$ A este respecto véase "Quiénes son las caras visibles del mundo militar en Venezuela". BBC Mundo, $202016 . \quad$ mayo Disponible en http://www.bbc.com/mundo/noticias/2016/05/160520_venezuela_caras_visibles_mundo_m ilitar_yv Recuperado en mayo de 2016.
} 
"Evo Morales tú eres la voz

que al imperialismo fue quien la enfrentó

para todos los hijos un gran porvenir

Anticapitalista y anticolonial." ${ }^{10}$

Según plantea Brian Loveman, las relaciones civiles-militares envuelven interacciones dinámicas entre diversos grupos, condicionados por circunstancias domésticas e internacionales (1999: xiii). Una circunstancia fundamental en tal sentido, fue el consenso global alcanzado sobre la democracia y el libre mercado. De esta manera, en un contexto internacional marcado por el fin de la Guerra Fría y la consecuente "tercera ola democrática", así como en ámbitos domésticos determinados por la pérdida de poder político por parte de las fuerzas armadas, éstas se encontraron con que su tradicional enemigo interno, identificado con el comunismo, desaparecía, lo que coadyuvó a la obsolescencia de la tradicional doctrina de seguridad nacional, propugnada desde Estados Unidos durante gran parte del conflicto bipolar. Sanahuja y Verdes-Montenegro señalan al respecto, que:

"Con el final de la Guerra Fría, los gobiernos de la región tuvieron que afrontar el formidable desafío de democratizar, desideologizar y situar en marcos civiles las visiones y doctrinas de seguridad y defensa dominantes en las décadas anteriores...Se trata de un proceso de hondo calado. Durante décadas, y en marco de una pauta hegemónica de relación con Estados Unidos, las concepciones tradicionales, centradas en la defensa de la soberanía territorial, quedaron subsumidas en las doctrinas de seguridad nacional de la guerra fría. Centradas en el

10 La marcha se encuentra disponible en http://www.cooperativa.cl/noticias/mundo/bolivia/evo-morales/polemica-en-boliviaejercito-compuso-himno-a-evo-morales/2016-05-31/215825.html Recuperado en mayo de 2016. 
mantenimiento del orden interno y con la subversión como principal amenaza, orientaron la estructura, entrenamiento y equipo de las fuerzas armadas contra el enemigo interno más que frente a eventuales amenazas exteriores" (Sanahuja y VerdesMontenegro, 2014: 490-491).

Ya en los noventa, con el dinamismo que adquiría el proceso de globalización, que en América Latina y otras regiones del mundo estuvo acompañado por el desarrollo de procesos de integración, las tradicionales visiones militarizadas sobre la seguridad dieron paso a nuevas perspectivas más multidimensionales y cooperativas, ya no centradas en la acumulación de armamentos y en las perspectivas clásicas geopolíticas sobre la disuasión. De hecho, prontamente la denominada "guerra contra las drogas" sustituyó al antiguo anticomunismo y a la lucha contra el "enemigo interno" como foco de la seguridad, proceso en el cual Estados Unidos cumplió un rol destacado en el plano continental. Estos cambios han sido elementos claves para entender el proceso de replanteamiento de las fuerzas armadas en su función y posicionamiento en las sociedades latinoamericanas.

Según destaca el profesor uruguayo Juan Rial, las fuerzas armadas latinoamericanas en la actualidad cumplen distintos roles:

"En algunos casos es sólo una fuerza de carácter disuasorio puramente militar. En otros, además, intervienen en funciones subsidiarias de control del orden interno con diversos alcances, asumiendo funciones policiales. En varios países están comprometidas en proyectos de asistencia social y hasta económica. Muchas fuerzas militares asumen un papel en el exterior como parte integrante de fuerzas de paz" (Rial, 2012:10).

El abanico sudamericano es diverso, encontrándose países que utilizan sus medios militares en variadas tareas vinculadas con la seguridad interna y el combate de amenazas transnacionales, como el crimen organizado y el 
terrorismo. Tal es el caso, entre otros, de Bolivia, Ecuador y Brasil. Este último país resulta particularmente ilustrativo, en tanto contempla la utilización de sus fuerzas armadas en labores de resguardo de la seguridad en las favelas, durante grandes eventos -como fue durante la celebración del Mundial de Fútbol de 2014 y de las Olimpiadas de Río de Janeiro en 2016- e incluso en el combate contra el mosquito Aedes Aegypty, responsable de enfermedades como el Zika, Dengue y Chikungunya. ${ }^{11}$ En otro extremo, países como Argentina y Chile han sido taxativos en establecer una clara división entre las funciones propias de militares y policías, o sea, entre aquellas materias relacionadas con la defensa, por un lado, y la seguridad pública, por otro. ${ }^{12}$ Aunque estas materias son actualmente materia de reflexión y análisis en estos países.

En el contexto regional, los países han hecho ingentes esfuerzos por incrementar las Medidas de Confianza Mutua, han avanzado en la transparencia de los gastos en defensa, han publicado Libros Blancos de la Defensa, han aumentado los ejercicios militares conjuntos, se ha diluido la posibilidad de confrontaciones bélicas y se ha impulsado el desarrollo de instancias o foros regionales, como es el caso del Consejo de Defensa Suramericano (Rial, 2012: 12). Además, con diversos grados de avance, varios países de la región están implementando procesos de planificación por capacidades, en sus respectivos sectores de defensa, dejando atrás el tradicional enfoque de la planificación por amenazas. Este es el caso, por ejemplo, de países como Argentina, Brasil y Chile.

Lo anteriormente expuesto es relevante, considerando la relación positiva que existe entre democracia y paz, desde la perspectiva de la antes mencionada teoría de la "paz democrática". Si bien las democracias en la región aún manifiestan debilidades y desafíos pendientes en materia de consolidación e institucionalización, lo cierto es que, de todos modos, su existencia ha favorecido importantemente la generación de un contexto regional propicio para la paz, donde

\footnotetext{
${ }^{11}$ Véase al respecto "Las FF.AA. brasileñas declaran la guerra al mosquito asociado con el virus Zika". Diálogo, 3 febrero 2016. Disponible en https://dialogoamericas.com/es/articles/las-ffaa-brasilenas-declaran-la-guerra-al-mosquito-asociado-conel-virus-zika Recuperado en marzo de 2017.

${ }^{12}$ Un buen análisis sobre la utilización de las fuerzas armadas en materia de seguridad y defensa, en el plano sudamericano, puede verse en Bartolomé (2009).
} 
los gobiernos han abandonado a la guerra como mecanismo de solución de conflictos, pese a las continuas divergencias entre los gobiernos, que profusamente cubren y exhiben los medios de comunicación.

En la actualidad, los gastos militares en la región están entre los más bajos del mundo, comparativamente con otras regiones. De hecho, según señala el Stockholm International Peace Research Institute (SIPRI), América Latina es la región del mundo que dedica proporcionalmente menos recursos a sus presupuestos militares, poco más del 1\% del PIB regional. En su informe de 2016, la referida institución señaló que, si bien los gastos en el mundo crecieron hasta casi 1,7 billones de dólares, equivalente al 1\%, en la región de América Latina y el Caribe la inversión bajó en un 2,9\%, hasta los 67.000 millones de dólares, lo que se explica principalmente por el recorte de Venezuela, afectada por una grave crisis económica y por los bajos precios del petróleo. ${ }^{13}$

En el plano propiamente sudamericano, según se señala en el Registro Suramericano de Gastos Agregados en Defensa 2006-2015, preparado por el Centro de Estudios Estratégicos de Defensa de la UNASUR, el gasto suramericano en este sector, como porcentaje del PIB regional, se muestra estable a lo largo de la década, con un promedio de 0,98\%. Este porcentaje, a juicio del CEED, evidenciaría que Sudamérica se encuentra a nivel mundial por debajo de otras regiones, en lo que refiere a la relación defensa/PIB regional (CEED, 2017: 29). Complementando lo anterior, María Celina D’Araujo sostiene que en la "En la región no hay percepción de amenazas militares que estimulen el crecimiento de los ejércitos" (D’Araujo, 2013: 11).

No obstante lo anterior, cabe hacer una breve digresión sobre esta temática. Como evidencia el siguiente cuadro, preparado por Carlos Wellington, que muestra la composición general y agregada del gasto militar de los países de América del Sur, Brasil destaca como el país que más gasta, de manera coherente con su condición de ser el país de mayor tamaño relativo de la región, en términos

\footnotetext{
${ }^{13}$ En el informe, el único país de la región que aparece entre los 15 que más gastan en defensa en el mundo, es Brasil, con una inversión de 24,6 mil millones de dólares. Esta información se encuentra disponible en http://www.t13.cl/noticia/mundo/america-latinaredujo-su-gasto-militar-ultimo-ano Recuperado en abril de 2016.
} 
geográficos, económicos y en lo referente a sus intereses estratégicos, que abarcan la defensa de la Amazonía, su proyección marítima en el Atlántico Sur y la búsqueda de capacidad militar aérea. A su vez, Paraguay se demuestra en todos los años analizados como el país que menos ha gastado en defensa (Wellington: 2012: 227).

Gasto en dólares estadounidenses (US\$ millones)

\begin{tabular}{|l|l|l|l|l|l|l|}
\hline País / Año & $\mathbf{2 0 0 5}$ & $\mathbf{2 0 0 6}$ & $\mathbf{2 0 0 7}$ & $\mathbf{2 0 0 8}$ & $\mathbf{2 0 0 9}$ & $\mathbf{2 0 1 0}$ \\
\hline Argentina & 1.853 & 1.910 & 2.211 & 2.512 & 2.982 & 3.179 \\
\hline Bolivia & 274 & 277 & 307 & 361 & 347 & 314 \\
\hline Brasil & 19.802 & 20.504 & 22.114 & 23.528 & 25.704 & 28.096 \\
\hline Chile & 5.090 & 5.633 & 5.781 & 5.626 & 5.679 & 6.198 \\
\hline Colombia & 6.541 & 6.909 & 7.430 & 8.323 & 8.569 & 9.191 \\
\hline Ecuador & 1.146 & 1.108 & 1.493 & 1.628 & 1.915 & 2.116 \\
\hline Paraguay & 94 & 106 & 108 & 119 & 126 & 146 \\
\hline Perú & 1.434 & 1.476 & 1.416 & 1.387 & 1.712 & 1.992 \\
\hline Uruguay & 335 & 341 & 349 & 398 & 503 & 491 \\
\hline Venezuela & 4.558 & 6.014 & 5.020 & 5.562 & 4.273 & 3.106 \\
\hline
\end{tabular}

Fuente: Elaborado sobre la base de los datos de SIPRI, por Wellington (2012:227).

En el mismo estudio se señala que los tres países que dedican menos recursos presupuestarios a sus sectores de defensa, en términos nominales, son Uruguay, Bolivia y Paraguay. Asimismo, como porcentaje del PIB de cada país, el autor plantea que, siendo Brasil el país con un mayor presupuesto militar en la región en términos absolutos -cuyo valor aportado al respectivo sector defensa es muy superior al destinado por cualquier otro país- el porcentaje impresiona bastante menos, representando sólo el $1,6 \%$ en 2009 , poco menos de la mitad del porcentual del PIB destinado a gastos militares en Ecuador ( $3,4 \%$ PIB), Chile $(3,6 \%$ PIB $)$ y Colombia $(3,7 \%)$. Además, Argentina y Paraguay son los que dedican el menor porcentaje del PIB a gastos militares (Wellington: 2012: 232234).

Según Wellington, en América del Sur el gasto militar es percibido por la ciudadanía como un gasto innecesario o de baja prioridad frente a otros de mayor significado social, en un contexto donde la percepción sobre las amenazas a la seguridad, derivadas de conflictos bélicos, es baja. Para este autor, "cualquier inversión en Defensa suele ser vista como un desperdicio de recursos que podrían 
estar siendo destinado a otros fines más importantes..." (Wellington: 2012: 236). En suma:

"El gasto militar de los países miembros de la Unión Suramericana de Naciones (UNASUR) presenta rasgos típicos que los diferencian de los gastos militares en otras regiones del mundo. Son gastos militares realizados en una región políticamente estable y con bajo potencial de conflicto entre Estados" (Wellington: 2012: 240).

Como es posible apreciar, la región de América Latina, y particularmente el contexto sudamericano, pese a la subsistencia de ciertos problemas limítrofes, es una de las regiones con un menor número de conflictos bélicos, y donde se ha paulatinamente superado el clásico pensamiento geopolítico, cediendo terreno la disuasión en favor de la cooperación, en el contexto de las respectivas políticas de defensa. En palabras de Francisco Rojas:

“...a lo largo de ya más de dos décadas por lo menos, nuestra región es una zona de paz, no hay espacio - en la actualidad para conflictos militares en América Latina y el Caribe. Hemos aprendido a resolver el conjunto de disputas sobre temas de fronteras o temas vinculados a la soberanía desde una perspectiva de la judicialización, por medio de tribunales internacionales" (Rojas: 2012: 273).

Todos estos avances permitirían caracterizar a América del Sur -además de ser un subcontinente donde predomina la democracia- como una Zona de Paz marcada por el creciente desarrollo de una comunidad de seguridad, donde se hace improbable la solución de los conflictos internacionales mediante el uso de la fuerza. La mayor expresión de ello sería la constitución y desarrollo que exhibe el Consejo de Defensa Suramericano. 
También resultan representativos los distintos acercamientos bilaterales que se aprecian en la región, como es el que se evidencia entre Colombia y Venezuela, que hacia fines de 2011, y luego de fuertes tensiones, alcanzaron un acuerdo de libre comercio, lo que ha dinamizado el comercio bilateral. También se aprecia una distensión en las relaciones entre Colombia y Ecuador, luego de las graves divergencias suscitadas entre ambos países, con motivo del ataque militar colombiano en territorio fronterizo de Ecuador contra las Fuerzas Armadas Revolucionarias de Colombia (FARC), en marzo de 2008.

Igualmente, cabe mencionar el incremento de la cooperación militar entre Ecuador y Perú, países que luego de haber llegado al enfrentamiento bélico a mediados de los noventa, han fortalecido la cooperación para enfrentar amenazas a la seguridad, como el crimen organizado y los riesgos de desastres naturales. Estos avances han sido el fruto, entre otros elementos, de las rondas de conversaciones militares entre los altos mandos de las fuerzas armadas de ambos países, que se realizan desde el año 2000, luego de la firma del acuerdo de paz definitivo de 1998. En el evento inaugural de la XVIII ronda de diálogo bilateral, el teniente general Leonardo Barreiro, de Ecuador, manifestó que "estas conversaciones fortalecen más los lazos de amistad, camaradería, profesionalismo y confianza mutua existentes entre los dos países". ${ }^{14}$

En la relación chileno-boliviana cabe destacar que ambos países han retomado la celebración de las reuniones del Comité de Frontera e Integración, que no se habían llevado a cabo desde 2011. Dicho Comité fue creado en marzo de 1997, comprendiendo las regiones chilenas I de Tarapacá y II de Antofagasta y los Departamentos de La Paz, Oruro y Potosí de Bolivia, así como los pasos fronterizos habilitados entre ambos países y su correspondiente área geográfica. Este mecanismo corresponde al foro bilateral para el tratamiento de los temas de interés común del área fronteriza, teniendo como objetivo el promover la facilitación y coordinación fronteriza mediante la formulación de recomendaciones para la adopción de medidas que agilicen el movimiento de personas, vehículos y

\footnotetext{
14 Véase la nota de prensa disponible en http://www.infodefensa.com/?noticia=altosmandos-militares-de-ecuador-y-peru-fortalecen-lucha-contra-delitos-transnacionales Recuperado en agosto de 2013.
} 
mercaderías a través de la frontera común, así como proyectos de desarrollo fronterizo. Durante 2017 el mecanismo bilateral se reunió en dos ocasiones: en julio, en la ciudad de Santa Cruz de la Sierra, y luego en octubre, en la ciudad de Arica. Entre los temas tratados están la Facilitación Fronteriza; Controles Integrados; Cooperación Aduanera; Asuntos Migratorios; y Cooperación Policial, entre otros. ${ }^{15}$

Una especial mención requiere el nivel de confianza y acercamiento alcanzado entre Argentina y Chile, por cuanto las relaciones entre ambos países resultan ejemplares al momento de ilustrar el avance hacia una comunidad de seguridad en la región. Estas naciones, que el año 1978 estuvieron a horas del estallido de la guerra, debido a las insalvables diferencias que mantenían respecto de la posesión sobre las islas y el territorio de Tierra del Fuego, luego de la firma del Tratado de Paz y Amistad de 1984 y, sobre todo a partir de la llegada de los gobiernos democráticos en ambos países, han avanzado de manera vigorosa hacia relaciones marcadas por la confianza y la cooperación. Según señala la profesora argentina María Elena Lorenzini:

"En 1984, ambos Estados decidieron poner fin a un pasado histórico signado por una imagen recíproca de rivalidad intensa. Aquel acuerdo celebrado entre el gobierno autoritario de Augusto Pinochet y el gobierno democrático de Raúl Alfonsín fue la piedra basal sobre la cual empezaría a construirse un nuevo modo de vinculación" (Lorenzini, 2013: 40).

Entre otros temas, por ejemplo, cabe destacar los aportes de los Comités de Integración y Frontera a las relaciones entre ambos países, los que persiguen dinamizar la actividad subnacional y las actividades conjuntas de las sociedades civiles de las partes, en torno a temas relacionados con los ámbitos productivo, educativo, cultural y turístico. La fuerte relación chileno-argentina, que se ha catalogado como una "alianza estratégica" -donde ambos países han eliminado

\footnotetext{
${ }^{15}$ Esta información se encuentra disponible en http://www.difrol.gob.cl/bolivia/comite-de-fronterachile-bolivia.html Revisado en diciembre de 2017.
} 
las mutuas hipótesis de conflicto-, ha seguido fortaleciéndose en el tiempo, pese a diversas tensiones que han aparecido en el plano bilateral, como fueron la denuncia de espionaje diplomático en el Consulado de Argentina en Punta Arenas, el año 2003; la crisis del gas de 2004; y el caso Apablaza. ${ }^{16}$

En las relaciones bilaterales chileno-argentinas, destaca la existencia de diversos arreglos durante la década de los noventa y significativos cambios en las operaciones militares combinadas entre las fuerzas armadas. También cabe subrayar las negociaciones por los límites del monte Fitz Roy y el cerro Daudet, que terminaron con gran parte de las disputas territoriales entre ambos países. En noviembre de 1995 Argentina y Chile firmaron el Memorándum de Entendimiento para el Fortalecimiento de la Cooperación en Materia de Seguridad de Interés Mutuo, a través del cual se creó el Comité Permanente de Seguridad (COMPERSEG), que reúne a los Subsecretarios de Relaciones Exteriores y de Defensa, con la finalidad de establecer una agenda de trabajo que permita la profundización de la cooperación entre ambos países en el ámbito estratégico. Desde su creación, el COMPERSEG ha asegurado un continuo diálogo político en torno a las materias de defensa entre Argentina y Chile, fortaleciendo la cooperación y el intercambio entre los actores civiles y militares.

Las reuniones del citado Comité han arrojado como resultado, entre otros avances, el diseño y aplicación de índices estandarizados de medición de gastos militares -con el apoyo de la CEPAL-, el desarrollo de ejercicios y actividades conjuntas y combinadas entre las respectivas fuerzas armadas, así como el trabajo coordinado en operaciones de paz y ante desastres naturales. En tal sentido, cabe destacar la realización de la Patrulla Antártica Naval Combinada (PANC), que desde el año 1998 llevan a cabo las armadas de ambos países; ${ }^{17}$ la

\footnotetext{
${ }^{16}$ Galvarino Apablaza es acusado de ser el autor intelectual del asesinato del senador chileno Jaime Guzmán, perpetrado en abril de 1991 en Santiago. Al momento en que se escriben estas líneas Apablaza se encuentra en Argentina en calidad de refugiado político, aunque este status fue revocado en diciembre de 2017 por el gobierno de ese país, lo que abre la posibilidad de que sea extraditado a Chile.

17 Véase a este respecto el comunicado de prensa disponible en http://www.armada.cl/armada/noticias-navales/chile-y-argentina-inician-nuevo-patrullajeantartico-naval/2014-11-12/090331.html Recuperado en junio de 2015.
} 
reparación en los astilleros de ASMAR Chile del destructor argentino Hércules; así como la existencia de un acuerdo para la construcción conjunta de buques para las armadas (Garay, 2003:95; Rojas, 2002; Griffiths, 2006).

Especialmente destacable resulta la creación de la Fuerza de Paz Conjunta Combinada "Cruz del Sur", ${ }^{18}$ una iniciativa sin precedentes en la región, que demuestra la madurez y consolidación política de la relación de ambos países. La riqueza de la relación bilateral en el plano estratégico, ha llevado al ex Ministro de Defensa de Chile, Jorge Burgos, a sostener que:

“...con Argentina mantenemos una relación estratégica, muy importante para nosotros, de la que nos sentimos contentos por su devenir y por la decisión de construirla cotidianamente, de tal suerte que las hipótesis históricas de conflicto entre nuestras dos naciones vayan quedando en el olvido" (Burgos, 2014: 168).

El 18 de enero de 2016, el Ministro de Relaciones Exteriores de Chile, Heraldo Muñoz, visitó Argentina para reunirse con su par, Susana Malcorra, y la Vicepresidenta Gabriela Michetti, encuentro durante el cual fue expresa la buena relación bilateral. Junto con fijar la fecha de una nueva reunión del Mecanismo 2+2, que reúne a los Ministros de Relaciones Exteriores y de Defensa de ambos países, las autoridades comunicaron la decisión de sus gobiernos de profundizar la relación estratégica bilateral. El Ministro Muñoz sostuvo, en tal sentido, que "...lo que hemos hecho es planificar el trabajo, retomando lo que ya ha venido

${ }^{18}$ Cabe señalar que esta fuerza de paz entró en condición de Stand-by a partir del 1 de Enero de 2012, integrándose al sistema UNAS de Naciones Unidas (United Nations Standby Arrangements System), lo que significa que actualmente está en condiciones de despliegue, a solicitud de Naciones Unidas, previo consentimiento de ambos países. Una experiencia similar a la Fuerza Cruz del Sur es la Compañía de Ingenieros "Libertador Don José de San Martín", constituida entre Argentina y Perú, a partir del Memorandum de Entendimiento firmado en octubre de 2008. 
siendo una muy buena relación entre los dos países, pero que creemos puede profundizarse aún más en muchos planos..."19

También han sido relevantes últimamente el estrechamiento de las relaciones entre Chile y Uruguay en el plano estratégico, que se expresa, entre otras instancias, en distintas reuniones bilaterales, una activa cooperación en materia de participación en operaciones de paz -como fue particularmente visible en el marco de la MINUSTAH-, así como en el mantenimiento, por parte de la firma chilena ENAER, de un avión Hércules C-130B, de la Fuerza Aérea Uruguaya. ${ }^{20}$ Igualmente lo son las nutridas relaciones entre aquel país y Ecuador, que se expresan, por ejemplo, en la modernización de los dos submarinos clase 209 de la Armada de Ecuador, en la planta industrial de ASMAR en Talcahuano, Chile. ${ }^{21}$

En la relación chileno-peruana, y más allá del diferendo limítrofe llevado a la Corte Internacional de Justicia, cabe destacar que el 16 de noviembre de 2012 se celebró en Torre Tagle la $\vee$ Reunión del Comité de Seguridad y Defensa PerúChile (COSEDE), mecanismo institucionalizado para el diálogo y la cooperación en materia de seguridad, defensa y fortalecimiento de la confianza mutua. La agenda de la reunión, que se realizó luego de seis años, permitió reiniciar las

${ }^{19}$ Véase la nota "Relación Chile-Argentina: hechos y no palabras". Boletín Cancillería en Acción, 28 enero 2016.2 Disponible en https://issuu.com/minrel_chile/docs/boleti_n_cancilleria_en_accio_n_1 Recuperado en abril 2017. También véase "Heraldo Muñoz: Se abrió una ventana de oportunidades con la Argentina; Chile la tiene que aprovechar". La Nación, 25 enero 2016. Disponible en http://www.lanacion.com.ar/1865028-heraldo-munoz-se-abrio-una-ventana-deoportunidades-con-la-argentina-chile-la-tiene-que-aprovechar Revisado en enero de 2016.

${ }^{20}$ A este respecto, se puede consultar "Fuerza Aérea Uruguaya moderniza uno de sus aviones Hécules C-130B". Diálogo, 5 febrero 2016. Disponible en https://dialogoamericas.com/es/articles/la-fuerza-aerea-uruguaya-moderniza-uno-de-sus-aviones-herculesc-130b Recuperado en febrero de 2016. También "Uruguay y Chile aumentan la cooperación contra el terrorismo y el crimen organizado". Diálogo, 19 mayo 2016. Disponible en https://dialogo-americas.com/es/articles/uruguay-y-chile-aumentan-lacooperacion-contra-el-terrorismo-y-el-crimen-organizado Recuperado en mayo de 2016.

${ }^{21}$ Véase el comunicado de prensa de la Armada de Chile "Finalizó proyecto de modernización de submarinos ecuatorianos en ASMAR Talcahuano". 27 septiembre 2014. Disponible en https://www.armada.cl/armada/noticias-navales/finalizo-proyecto-demodernizacion-de-submarinos-ecuatorianos-en-asmar-talcahuano/2014-09-26/193049.html Recuperado en abril de 2017. 
conversaciones entre ambos países en torno a una metodología para la medición de los gastos en defensa, renovar el compromiso para incrementar la cooperación y coordinación en la lucha contra los delitos transnacionales en la zona fronteriza y concertar posiciones comunes en foros multilaterales del ámbito de la defensa, entre otros temas relevantes.

Si bien el COSEDE no se ha vuelto a reunir desde entonces, cabe señalar que con la asunción del Presidente Pedro Pablo Kuczynski en Perú se ha retomado la agenda bilateral, esperándose retomar este mecanismo. El Presidente peruano ha sido explícito en señalar que la relación bilateral debe abordarse de manera pragmática, concentrándose en la activa agenda comercial, dejando de lado el tema marítimo que tensa las relaciones entre Bolivia y Chile. ${ }^{22}$

En razón de lo anterior, retomando el diálogo bilateral en el plano político y estratégico, los Ministros de Relaciones Exteriores y de Defensa de ambos países, se volvieron a reunir el 28 de junio de 2017, en el marco del Mecanismo 2+2, con el objeto de fortalecer e intensificar la cooperación en el ámbito de la defensa. ${ }^{23} \mathrm{La}$ última sesión de este instrumento se había celebrado en 2014, tras el fallo de La Haya. En la ocasión, el Canciller peruano, Ricardo Luna, señaló que los gobiernos "se encuentran comprometidos en dar un renovado impulso a la relación bilateral. Marca un hito en un contexto complicado. Nosotros estamos, como se ha dicho varias veces, sobre todo a partir del año pasado, en un mundo convulso, complicado...Quisiera resaltar el compromiso de reactivar los ejercicios combinados para enfrentar terremotos y tsunamis en la zona de frontera. Esto fortalecerá las labores de prevención y desastres". ${ }^{24}$

Por último, es necesario resaltar el nivel de las relaciones entre Brasil y Argentina, la más relevante y estratégica de la región, como los actores mayores y

\footnotetext{
22 "Perú evita el tema marítimo y quiere hablar de negocios". El Deber, 28 julio 2016. Disponible en http://notibol.com/noticia/per-evita-el-tema-martimo-y-quiere-hablar-denegocios/635988 Revisado en abril de 2017.

${ }^{23}$ Véase "Chile-Perú: La declaración de la reunión 2+2 y los acuerdos adoptados". Infogate, 29 junio 2017. Disponible en http://www.infogate.cl/2017/06/29/chile-peru-ladeclaracion-de-la-reunion-22-y-los-acuerdos-adoptados/ Recuperado en junio 2017.

${ }^{24}$ Véase la nota de prensa "Chile retomó el diálogo 2+2 con Perú". Disponible en http://www.cooperativa.cl/noticias/pais/relaciones-exteriores/peru/chile-retomo-el-dialogo-2-2-conperu/2017-06-28/114132.html Revisado en diciembre de 2017.
} 
representantes sudamericanos entre los denominados países del mundo emergente. En el siglo XIX ambos países estuvieron en guerra durante los años 1825 y 1828, firmando finalmente el Tratado de Montevideo, que reconoce la independencia de Uruguay, que en sus orígenes surge como un estado tapón, o como "un algodón entre dos cristales", en palabras de un conocido político británico. Este hecho no borró la competencia de ambos países, la que vino sólo a ser superada hacia mediados de la década de 1980, en el marco del proceso de acercamiento derivado de las respectivas transiciones a la democracia, cuyo mayor resultado fue el establecimiento del MERCOSUR en 1991.

En la actualidad, cabe subrayar la existencia del Mecanismo de Consulta y Coordinación entre Argentina y Brasil en materia de Defensa y Seguridad Internacional, establecido a partir de 1997, en el cual participan los Ministros de Relaciones Exteriores y de Defensa de ambos países. La cooperación bilateral en temas estratégicos entre estos países se ha expresado en proyectos comunes, entre otros, en materia de capacitación y entrenamiento; ciencia, tecnología y producción en defensa; desastres naturales; ciberdefensa; y en los temas Antártica y Atlántico Sur. Ya en abril del año 1997 los Presidentes de ambos países concordaron, en la Declaración de Río de Janeiro, que:

"...esta alianza existe porque tenemos una firme comunión de valores. Nuestras sociedades son democráticas, plurales, defienden las libertades, los derechos humanos y la libre iniciativa como medio de promover la prosperidad, así como la justicia social como medio de asegurar la concordia como fundamento de nuestro modo de vida" (véase Diamint, 1999: 54).

El dinamismo de las relaciones fue patente durante la visita que el Ministro de Defensa de Brasil, Celso Amorim, realizó a Buenos Aires en septiembre de 2011, donde se reunió con su par argentino, brindó una conferencia en la Escuela de Defensa Nacional y se reunió con la entonces Presidenta Cristina Fernández. Durante el encuentro bilateral, las delegaciones abordaron las áreas de cooperación en torno a la profundización del diálogo político-estratégico; los 
proyectos comunes en ciencia, tecnología y producción en defensa; cooperación militar y proyectos comunes sobre la Antártica y el Atlántico Sur.

En abril de 2012, en una nueva reunión entre los Ministros de Defensa de ambos países, esta vez en Brasilia, se dialogó sobre la continuación de la elaboración de una estrategia común para el desarrollo científico-técnico en el campo de la defensa, así como respecto de la UNASUR y el Consejo de Defensa Suramericano. Durante el evento, Amorim señaló que "la relación con la Argentina es la más estratégica de todas las relaciones". En esa ocasión, ambas autoridades coincidieron en la necesidad de profundizar los temas de la agenda bilateral, tales como los relativos a la capacitación y entrenamiento de las escuelas militares, la relación entre las industrias para la defensa de Argentina y Brasil y la necesidad de avanzar en los ámbitos de la defensa cibernética y la asistencia entre los países ante situaciones de desastres naturales.

Como ejemplo de las fluidas relaciones entre ambos países, cabe destacar igualmente el proyecto Gaucho, para fabricar un vehículo blindado y el desarrollo de un satélite conjunto; así como los ejercicios conjuntos Yaguareté y Hermandad que, a juicio del General Jorge da Costa (Brasil), pretenden “...consolidar los lazos de unión, cooperación y amistad entre los dos ejércitos, además de un entendimiento mutuo de procedimientos, métodos y técnicas a emplear", al mismo tiempo que "....aumentar los conocimientos profesionales y doctrinarios que contribuyan a la interoperabilidad entre los dos ejércitos", según el General Gustavo Fernando Booth (Argentina). ${ }^{25}$

Luego de los cambios de gobierno en ambos países las relaciones se mantienen constantes. En febrero de 2017, con ocasión de una reunión bilateral entre los Presidentes Mauricio Macri y Michel Temer, el Presidente argentino, a propósito de la necesidad de fortalecer el MERCOSUR y retomar las negociaciones del bloque con la Unión Europea, señaló que "frente a tantas dudas que nos plantea el mundo, lo que nos tiene que quedar cada vez más claro es que tenemos que ser

\footnotetext{
${ }^{25}$ Véase "Fuerzas Armadas de Brasil y de Argentina participan en entrenamiento conjunto para estrechar vínculos". Diálogo, 20 enero 2016. Disponible en https://dialogoamericas.com/es/articles/fuerzas-armadas-de-brasil-y-de-argentina-participan-enentrenamiento-conjunto-para-estrechar-vinculos Recuperado en enero de 2016.
} 
aliados del siglo XXI... el afecto de Argentina hacia Brasil está cada vez más fuerte y quiero que definitivamente entendamos que somos socios, que tenemos mucho que intercambiar y que la rivalidad la dejemos para el fútbol”. ${ }^{26}$

También, desde el año 2000, Brasil ha estado trabajando bilateralmente con otros países de la región, a través de diversos grupos de trabajo bilaterales de Defensa. Tales instancias de diálogo pretenden intensificar los lazos existentes de cooperación, intercambio e integración entre las respectivas fuerzas armadas. Este es el caso del Mecanismo 2+2 con Paraguay, que se reunió por primera vez el 4 de abril de 2016, luego de su firma en el año 2007, ocasión en la cual las partes abordaron materias como la cooperación militar y el control del tráfico fronterizo, considerando los $1400 \mathrm{kms}$. de frontera que comparten ambos países.

Todos los hechos anteriormente enunciados resultan particularmente relevantes, en tanto la formación de una comunidad de seguridad requiere del aumento de la interacción entre los actores, la socialización paralela entre éstos y el consecuente desarrollo de una eventual identidad regional.

Si bien aún no puede sostenerse el pleno desarrollo de tales elementos, la relevancia de las instancias antes reseñadas es que demuestran el incremento de la confianza a nivel de los gobiernos y de las fuerzas armadas. En el plano militar, las actividades combinadas han mejorado la preparación profesional, al mismo tiempo que han instaurado relaciones personales de mutuo conocimiento entre los actores involucrados. De este modo, estos avances en el terreno bilateral han modificado las percepciones negativas y competitivas hacia percepciones positivas centradas en los beneficios de la cooperación y la integración.

Como se planteó más arriba, los avances bilaterales recién expuestos, que se deben considerar al momento de caracterizar una región marcada por la paz, estabilidad y cooperación, están contextualizados en un escenario donde predomina la democracia -aunque con distintos niveles de consolidación- y donde

\footnotetext{
${ }^{26}$ Véase al respecto "Macri hace un llamado a fortalecer internamente el Mercosur y mirar México como un aliado". Disponible en http://www.pulso.cl/actualidadpolitica/internacional/macri-llamado-fortalecer-internamente-mercosur-mirar-mexicoaliado/ Revisado en abril de 2017.
} 
los militares han progresivamente dejado de constituirse como actores políticos, predominando la subordinación a los poderes civiles, sin perjuicio de las diferentes interpretaciones que se ha hecho en los países acerca de los alcances de la utilización de los medios militares para asumir los temas de seguridad y defensa. Como señala Roberto Russell, "La democracia es dispareja y en ciertos casos hasta incierta, pero constituye el sustento de nuevos modos de cooperación y concertación entre los países" (Russell, 201: 137).

Por último, con el objeto de complementar el panorama político regional, es necesario expresar algunos desafíos que actualmente deben enfrentar los países, con el fin de seguir avanzando en la positiva correlación entre democracia, integración y seguridad. Entre otros, por ejemplo, cabe mencionar la persistencia de diferencias limítrofes que, si bien han sido predominantemente canalizadas por el camino de la negociación y las instancias jurídicas internacionales, igualmente se presentan como un obstáculo en el ascenso hacia una comunidad de seguridad madura, como lo es la Unión Europea.

Otros temas son la competencia ideológica que se aprecia entre ciertos países; la existencia de líderes autoritarios que usualmente invocan el nacionalismo para generar apoyo interno a sus políticas; las acentuadas desigualdades políticas, sociales y económicas; la competencia por recursos naturales y energéticos; inversiones extranjeras que potencialmente generan roces bilaterales; y la presencia de actores extrarregionales, que pueden implicar disrupciones entre los países, como es el caso de China, Irán y la Federación de Rusia, recientemente, y la histórica presencia de Estados Unidos, que se podría remontar a la Doctrina Monroe del año 1823 (Mares, 2012).

Respecto de la presencia estadounidense en la región, cabe mencionar la reactivación de la Cuarta Flota, en julio de 2008. Aunque no está claro si ello responde a una reorganización interna del instrumento militar norteamericano, o bien está orientado a recuperar la presencia de ese país en un contexto de creciente penetración china y de otros actores extrarregionales, y de desarrollo de mecanismos regionales de seguridad, como es el CDS. Lo cierto es que el anuncio de su restablecimiento generó preocupaciones y críticas en distintos países, particularmente desde Cuba, Venezuela, Brasil y Argentina. 
En complemento de lo anterior, no puede dejar de mencionarse el hecho de que actualmente la región se encuentra entre las zonas más violentas del mundo, desde la perspectiva de la seguridad interna (Brum y Burgoyne, 2017: 5; Cubel, 2016), lo que actualmente representa una de las mayores preocupaciones para la población y uno de los más apremiantes desafíos que deben enfrentar las democracias latinoamericanas. Ello se contextualiza en una región con extensas zonas de porosidad de las fronteras, cuestión que ha servido como un aliciente al narcotráfico y al crimen organizado, y que también se encuentra en la base de ciertas tensiones bilaterales, como han sido los frecuentes roces entre Colombia y Venezuela, Colombia y Ecuador, Chile y Bolivia, entre muchos otros (Mares, 2012). Es decir, si los esquemas de integración han contribuido a la estabilidad y la paz interestatal, la interdependencia regional ha tenido efectos nocivos en el plano de la seguridad pública, facilitando la expansión de las redes criminales.

Según sostiene Lucía Dammert (2012), en aquellos temas que tienen que ver con la seguridad interna, es decir, la percepción de la criminalidad, la ocurrencia de crímenes violentos, el fácil acceso a armas, las manifestaciones violentas y la evaluación de la policía, la región está marcada por la inseguridad. Si bien las hipótesis de conflicto tradicionales han disminuido ostensiblemente, la violencia criminal se ha instalado como una de las más importantes prioridades de los gobiernos de la región.

En consecuencia, ante este complejo panorama, podría bien catalogarse a la región como una Zona de Paz Violenta. Es decir, pacífica desde el punto de vista interestatal, pero muy conflictiva, considerando los índices de la seguridad pública y ciudadana. En suma, el crimen organizado y el narcotráfico representarían, en palabras de Roberto Russell, "el lado oscuro de la luna en materia de relaciones intrarregionales" (2011: 126). 


\section{5.- Integración y seguridad en América del Sur. Los antecedentes regionales y subregionales del Consejo de Defensa Suramericano}

Según el capítulo VIII de la Carta de las Naciones Unidas, las organizaciones regionales que sean compatibles con los propósitos y principios de la organización, pueden actuar en apoyo de sus objetivos de paz y seguridad. Esta disposición representa la base de varios acuerdos hemisféricos, regionales y subregionales en las Américas, celebrados a partir de la Segunda Guerra Mundial, como es el caso de la Carta de la Organización de Estados Americanos (OEA) y el Tratado Interamericano de Asistencia Recíproca (TIAR).

Como ya se ha indicado, América del Sur, región en la cual se concentra el presente trabajo, es una de las regiones más pacíficas del mundo, desde la perspectiva de los conflictos interestatales, libre de armas de destrucción masiva y con el menor gasto de defensa, en contraposición con otras regiones donde perviven importantes y numerosos conflictos. Entregando un panorama global al respecto, el Programa de Recopilación de Datos sobre Conflictos de Uppsala (UCDP) señala que el número de conflictos armados activos pasó de 52 a 49 en 2016. Pese a esta reducción, el año 2016 confirma la tendencia a un número de conflictos mucho mayor en los últimos tres años en comparación con el periodo 2007-13. Según el UCDP, de los 49 conflictos activos en 2016, dos se llevaron a cabo entre Estados (India-Pakistán y Eritrea-Etiopia) y los demás al interior de Estados. El señalado Programa registró 12 guerras — definidas como el conflicto armado que da lugar a mil muertes en combate- en 2016, una más que en 2015. Tres de las registradas en 2015 habían reducido su intensidad y habían pasado a ser conflictos armados menores el año 2016 (Nigeria, Pakistán y Ucrania). A su vez, cuatro conflictos registrados anteriormente se agravaron hasta el nivel de guerra: Afganistán-Estado Islámico, Libia-Estado Islámico, Turquía-Estado Islámico y Turquía-Kurdistán. África fue la región con el mayor número de conflictos en 2016 (19), seguida por Asia (15). En Oriente Medio se registraron diez conflictos, en Europa tres y en América solamente dos (SIPRI, 2017: 2-3). Según dicho programa de Uppsala: 
"La reducción del número de conflictos en América Latina es especialmente destacable. Tras el acuerdo de paz de 2016 entre las Fuerzas Armadas Revolucionarias de Colombia-Ejército del Pueblo y el Gobierno colombiano, y con las negociaciones en curso con el Ejército de Liberación Nacional, el único grupo guerrillero que sigue en conflicto con el Gobierno colombiano, parece probable que la región pronto dejará de tener conflictos activos" (SIPRI, 2017:3).

En una columna de opinión publicada el 21 de febrero de 2017, con ocasión de la conmemoración de los 200 años de la batalla de Chacabuco y del Cruce de Los Andes -por parte de los ejércitos de Argentina y Chile- el Subsecretario de Defensa de Chile, Marcos Robledo, destacaba la condición de paz de América Latina, en contraste con un contexto internacional donde proliferan los conflictos y la incertidumbre. Según la mencionada autoridad de gobierno,

"Con algunas muy contadas excepciones, la región no ha experimentado conflictos durante un prolongado período y en términos comparados ha devenido, con distancia, una de las zonas más estables del planeta... lo que distingue a la región latinoamericana es que ha desarrollado una tradición de resolución pacífica de las controversias y de empleo de las instituciones del Derecho Internacional; ha proscrito las armas de destrucción masiva, y ha desarrollado una densa red de regímenes de confianza mutua que han permitido incrementar la transparencia y disminuir la percepción de amenaza". ${ }^{27}$

En este recuadro, diversos mecanismos de integración en América del Sur, como es el caso del MERCOSUR y la CAN, han realizado declaraciones donde califican

27 La columna se encuentra disponible en http://www.elmercurio.com/blogs/2017/02/21/49017/Los-200-anos-de-la-Batalla-deChacabuco-y-la-larga-paz-sudamericana.aspx Recuperada en febrero de 2017. 
a sus respectivas áreas como Zonas de Paz. Tal concepto surgió durante el siglo $\mathrm{XX}$ bajo el objetivo de sustraer un determinado espacio geográfico de la confrontación bipolar, que se daba en el mundo en el contexto de la Guerra Fría. ${ }^{28}$ A nivel sudamericano, cabe destacar que durante la primera Reunión de los Presidentes de América del Sur -antecedente de la UNASUR-, celebrada entre los días 31 de agosto y 1 de septiembre de 2000 en Brasilia, se acordó crear una Zona de Paz Sudamericana, hecho en el cual es posible vislumbrar algunos atisbos de lo que sería el futuro establecimiento del CDS.

En consecuencia, es posible apreciar distintos antecedentes a nivel hemisférico y regional para la constitución del CDS en diciembre del año 2008, como son las iniciativas y aportes en materia de defensa y seguridad que se han llevado a cabo en el seno de la OEA a nivel continental, así como en el MERCOSUR, la CAN y el ALBA a nivel subregional. En este acápite se analizan tales avances, sin descuidar, en un primer momento, el caso de la integración en Europa que, desde luego, representa un antecedente de relevancia para cada proceso de integración que se ensaye en cualquier región del mundo, pese a las dificultades que enfrenta actualmente la Unión Europea, derivadas de la decisión del Reino Unido de retirarse, en el marco del denominado BREXIT. En el plano sudamericano, no se abordará en este apartado la Alianza del Pacífico, por ser una instancia con un enfoque predominantemente comercial, donde hasta ahora el tema de la defensa ha quedado fuera de las discusiones.

\section{a) EI caso europeo}

El proceso de integración europeo, observado desde América del Sur, desde luego que sirve como marco de referencia para el proceso regional de este lado del mundo. Junto con Michel Levi, es posible señalar al respecto, que:

\footnotetext{
${ }^{28}$ La primera declaración de Zona de Paz estuvo referida al Océano Índico, respondiendo al interés de la India y otros Estados de la zona, de protegerse frente al riesgo de que las superpotencias incluyeran a dicho espacio en su confrontación, particularmente en lo relacionado con el uso de armamento nuclear (Grebe, 2004: 15).
} 
"Si bien la experiencia europea se ha desarrollado en una época determinada y bajo condiciones geográficas y políticas diferentes a la sudamericana, consideramos que podría tomarse en cuenta como un marco de referencia, desde la perspectiva de su experiencia temporal, de evolución institucional y jurídica" (Levi, 2012: 433-434).

En concreto, el tema de la paz estuvo desde sus orígenes presente en la integración de Europa, en tanto uno de los objetivos principales del continente fue la reconstrucción y el desarrollo de los países tras las atroces consecuencias de la Guerra Mundial. Los intentos unificadores en el plano de la seguridad y defensa fueron pioneros en el proceso de integración, incluso antes de que existiesen las comunidades europeas. Diversos antecedentes deben tenerse en cuenta en tal sentido, como es el caso de la firma del Tratado de Dunkerque, entre Francia y Reino Unido en 1947, que contiene una cláusula de asistencia armada, fundamentado particularmente en un posible rearme de Alemania. A este tratado luego se incorporarían Bélgica, Holanda y Luxemburgo.

Estos cinco países luego firmarían el Tratado de Bruselas en 1948, que alberga los cimientos de lo que luego será la Unión Europea Occidental (UEO). El documento, cuyo nombre in extenso es Tratado para la Colaboración Económica, Social y Cultural y Autodefensa Colectiva, firmado por Bélgica, Francia, Luxemburgo, Holanda y Reino Unido, llamaba a los Estados miembros a la asistencia mutua, en caso de un ataque armado. Junto a lo anterior, cabe anotar el establecimiento de la OTAN en 1949, en Washington D.C., así como de la Comunidad Europea del Carbón y el Acero (CECA) en 1951, mediante el tratado de París (Alemania, Bélgica, Francia, Italia, Luxemburgo y Países Bajos), que tenía el objetivo de poner los recursos estratégicos bajo una autoridad supranacional, evitando futuros conflictos entre los firmantes. La CECA serviría como modelo de la futura Comunidad Económica Europea y la Comunidad Europea de la Energía Atómica, establecida en 1957 con el Tratado de Roma. El proceso de integración europeo buscaba, en el fondo, estabilizar Europa, superando los niveles de conflictividad, derivados de anteriores "disputas por el 
control de bienes estratégicos para la producción, que sumadas a otras causas, ya habían dado como resultado dos guerras mundiales durante la primera mitad del siglo XX" (Levi, 2012: 435).

Sin perjuicio de lo anterior, cabe igualmente señalar que el proyecto común en el plano de la seguridad europea está íntimamente ligado con la OTAN. Aunque en los inicios de la integración europea se intentara consolidar la UEO como entidad encargada de la cooperación en el plano de las actividades de asistencia en caso de agresión, en favor de los miembros de la Comunidad Económica Europea (CEE) ${ }^{29}$ hasta la actualidad es la OTAN el verdadero pilar de la seguridad y defensa en Europa, como una alianza política y militar en forma de organización internacional de cooperación, conformada por los países de la UEO, otros países europeos y de América del Norte, bajo la dirección de los Estados Unidos (Levi, 2012: 436). De hecho, la UEO, formalmente establecida en 1954 mediante el Tratado de Bruselas modificado, desde su origen tuvo un alto nivel de superposición con las labores de la OTAN, lo que conllevaría que prontamente la unión entrara en una fase "durmiente".

En los años cincuenta se planteó la creación de una estructura paralela, con identidad comunitaria supranacional, denominada Comunidad Europea de Defensa, que daría el contexto para el eventual desarrollo de instituciones, fuerzas armadas y presupuesto común. Sin embargo, como plantea Levi, el Tratado constitutivo que instituyó la Comunidad no fue ratificado por parte de todos los miembros, particularmente debido a la fuerte oposición de la Asamblea Nacional de Francia. Los sectores más nacionalistas de este país se opusieron frontalmente a la idea de establecer unas fuerzas armadas europeas, por cuanto apreciaban como un peligro grave para el Estado el no poder contar, en caso de conflicto, con una capacidad de respuesta armada propia (Levi, 2012: 437-438). Para el citado autor, resulta evidente:

${ }^{29}$ Cabe anotar que al firmarse en 1957 el Tratado de Roma, mediante el cual se crea la $\mathrm{CEE}$, no se incluyen entre sus competencias los temas relacionados con la política exterior, la seguridad y la defensa. 
“...que el único intento de creación de una institucionalidad de defensa supranacional, a comienzos de los años cincuenta, resultó fallido y que durante la segunda mitad del siglo XX primaron las estructuras institucionales intergubernamentales, sujetas hasta los años noventa a una lógica que correspondía a la confrontación de las potencias del momento: Estados Unidos y la Unión Soviética URSS" (Levi, 2012: 438-439).

En la Cumbre de La Haya de 1969, los líderes europeos instruirían a los Ministros de Asuntos Exteriores para que examinaran la posibilidad de avanzar en la cooperación política. Con este impulso, los ministros introducirán la idea de la Cooperación Política Europea en el Informe Davignon, de octubre de 1970. Con esta base, en octubre de 1981 los Ministros de Asuntos Exteriores de la Comunidad Europea adoptarían el Informe de Londres sobre Cooperación Política Europea. Si bien el documento excluye el tema de la defensa, se refiere a la cooperación sobre ciertos asuntos políticos relevantes en materia de seguridad, introduciendo procedimientos para habilitar la organización de reuniones de crisis ante determinadas situaciones de emergencia.

En 1980 la UEO recibiría un nuevo ímpetu, a través del despliegue de la primera operación militar europea, conocida como la Operación Cleansweep, puesta en marcha en 1988 a fin de realizar actividades de desminado en el estrecho de Hormuz.

Luego, en junio de 1983, los Jefes de Estado y Gobierno de la Comunidad Europea adoptarán una declaración solemne sobre la unión europea, conocida como la Declaración de Stuttgart, que entrega las bases de una futura política exterior y de seguridad común. No obstante, es a partir del Tratado de Mastricht de 1992, que crea la Unión Europea, que se hace explícita la referencia a la Política Exterior y de Seguridad Común (PESC), que involucra la futura definición de una política de defensa común. También en el Tratado de Maastricht se establece que la Unión Europea se sustenta en tres pilares: Comunidades Europeas ( $1^{\circ}$ pilar), Política Exterior y de Seguridad Común/PESC $\left(2^{\circ}\right.$ pilar) y Justicia y Asuntos de Interior ( $3^{\circ}$ pilar). 
De este modo, el Tratado de Maastricht abrirá la puerta para una mayor colaboración con la UEO, por cuanto decide elaborar e implementar decisiones y acciones con implicancias en materia de defensa. En el mismo año 1992, el Consejo de Ministros de la Unión Europea Occidental, reunidos en Petersberg, establecen un nuevo rol operacional a la organización, disponiendo la conformación de unidades militares para un rango de tareas, que incluyen actividades humanitarias y de rescate, mantenimiento de la paz y gestión de crisis. Son las denominadas misiones Petersberg.

El Tratado de Amsterdam en 1997 reforzará la PESC, creando el cargo de Alto Representante de la Política Exterior y de Seguridad Común. Luego, el Tratado de Niza de $\mathbf{2 0 0 0}$ formaliza la PESC, dotándola de una estructura institucional, como encargada de ejercer el control político y la dirección estratégica de las operaciones de gestión de crisis de la Unión Europea. Tales labores serán fortalecidas con la Declaración Conjunta de Saint Malo sobre Defensa Europea, suscrita por Francia y Reino Unido en 1998, así como por los acuerdos emanados de la Reunión del Consejo de Europea de Colonia de 1999 y de Helsinki del mismo año.

En el tratado de Ámsterdam, asimismo, se establecerá la Política Europea de Seguridad y Defensa (PESD), como vertiente operativa y parte integrante de la PESC. En este instrumento,

“...los Estados europeos manifestaron su determinación de dotar a la Unión de medios, capacidades y recursos para llevar a cabo misiones de prevención y gestión de crisis, mientras que la OTAN continuaría siendo el fundamento de la defensa colectiva de sus miembros, algo que ha pervivido sin grandes cambios hasta el Tratado de Lisboa" (Peñaranda, 2012: 412-413).

En 2000, en la reunión de Santa María da Feira, el Consejo Europeo se concentrará en el desarrollo de las capacidades civiles para la gestión de crisis, que involucrarán las siguientes áreas prioritarias: policía, fortalecimiento del Estado de Derecho, fortalecimiento de la administración civil, y protección de 
civiles. Conjuntamente, el año 2003, a través de los acuerdos de Berlín Plus, se incrementa la coordinación entre la Unión Europea y la OTAN.

Es necesario igualmente señalar que en junio de 2011, la Unión Europea Occidental dejará de existir, en tanto sus funciones habian ido paulatinamente siendo incorporadas a la Unión Europea.

Según señala Levi, si bien el proceso europeo se instrumentó sobre una base económica, institucional y jurídica, en el fondo, su creación contó con una clara visión política donde la seguridad y defensa cumplieron un rol importante para afianzar la estructura comunitaria, aspecto fundamental de la construcción europea que, no obstante, no ha contado con una suficiente visibilidad fuera de Europa. Las condicionantes geopolíticas propias de la Postguerra -con el arranque de la Guerra Fría y el posicionamiento internacional de Estados Unidos- donde se establecieron las Comunidades Europeas durante los años cincuenta, no serían fácilmente replicables en la actualidad (Levi, 2012). Ello puede estar entre los fundamentos que expliquen el que el caso latinoamericano y sudamericano no hayan avanzado con la misma intensidad, no estando tampoco entre sus objetivos imitar el ensayo europeo, prefiriendo, en su lugar, mantener el proceso con una alta dosis de flexibilidad y escasa densidad institucional.

En el Tratado de Lisboa (2009) la PESD tomará el nombre de Política Común de Seguridad y Defensa (PCSD) para, como parte integral de la PESC, verse reforzada con mayores capacidades e instrumentos de actuación en materias de mantenimiento de la paz, prevención de conflictos y fortalecimiento de la seguridad internacional. Este tratado también busca mejorar la acción europea, con el establecimiento del puesto de Presidente del Consejo Europeo y el Alto Representante de la Unión para Asuntos Exteriores y Política de Seguridad. En Lisboa también se creará la Agencia Europea de Defensa, operativa desde 2004, con el objetivo de apoyar el trabajo de la PCSD, en temas relacionados con la investigación en defensa, cooperación en armamentos, desarrollo de capacidades y crear un mercado europeo de equipos de defensa, reforzando al mismo tiempo la base industrial y tecnológica de la defensa europea (Ministerio de Defensa de España, 2010; De Ayala, 2012). 
Asimismo, el Tratado de Lisboa amplía las Misiones Petersberg, que ahora involucran operaciones conjuntas de desarme, tareas humanitarias y de rescate, asesoría militar, prevención de conflictos y mantenimiento de la paz, fuerzas de combate en gestión de crisis, incluyendo mantenimiento de la paz y estabilización posconflicto. El Tratado de Lisboa incluye igualmente una cláusula de asistencia mutua y una de solidaridad, en caso de ataque terrorista, tomando en cuenta el atentado terrorista de Madrid de marzo de 2004.

Cabe señalar que el Tratado de Lisboa, incluyendo una sección específica sobre la PCSD, no otorga nuevas competencias a la estructura institucional de la Unión Europea, manteniéndose la capacidad de decisión en los Estados miembros, bajo el esquema de cooperación en el marco de sus políticas nacionales y de su participación individual en organismos internacionales. En consecuencia, se puede señalar junto a Michel Levi, que:

"Se ratifica entonces el carácter de cooperación intergubernamental de la política común de seguridad y defensa, sujeta a toma de decisiones por unanimidad, en el Consejo Europeo...Desde esta perspectiva las instituciones comunitarias juegan un papel bien delimitado por la propia estructura jurídica de la UE, que respeta la soberanía estatal y las estructuras internacionales consolidadas en materia de seguridad y defensa" (Levi, 2012: 441).

Hasta el presente, la definición de la PCSD se encuentra en manos del Consejo Europeo, donde las decisiones están sujetas al interés de participar de los Estados miembros y a sus respectivas políticas nacionales en el ámbito de la seguridad y la defensa. La debilidad de la Unión Europea en avanzar hacia una estructura más densa institucionalmente, de manera coherente con un eventual esquema supranacional, puede explicarse, como se señaló anteriormente, por la preferencia de los miembros por seguir actuando de acuerdo a sus respectivos intereses nacionales -contando con la OTAN para mantener la paz-, entre otros elementos, debido a la diversidad de intereses y prioridades en tales materias, como fue 
evidente durante la Guerra de Irak y lo siguen siendo las relaciones de dicha región con la Federación de Rusia. A ello se podría agregar la ilusión que algunos países todavía mantienen de cumplir un rol de nivel global de manera individual.

En el plano intergubernamental, en el cual se mueve aún la Unión Europea, la PCSD ha definido estructuras políticas y militares e instrumentos normativos para el manejo de crisis. Tales mecanismos, a partir del Tratado de Lisboa, han migrado del Consejo Europeo al nuevo Servicio Europeo de Acción Exterior (Levi, 2012: 439). A este respecto, es necesario señalar que la gestión de crisis se relaciona con la acción que desarrollan países, organismos internacionales 0 bloques de integración para abordar aquellos procesos relacionados con la construcción de la paz o peacebuilding, en Estados que han sufrido graves conflictos o guerras internas, buscando generar las condiciones necesarias para la construcción de la gobernabilidad, afianzar bases para la democracia y el fortalecimiento de la institucionalidad política y económica. En el marco de la PCSD, la Unión Europea ha venido desarrollando un importante trabajo que se ha expresado en la mayor experiencia a escala global en el ámbito de la gestión de crisis.

Las operaciones de gestión de crisis europeas tienen un acentuado componente civil-militar, estando desplegadas mayoritariamente en el entorno cercano al viejo continente, donde se concentran gran parte de sus intereses estratégicos, como es el caso de Medio Oriente, Cáucaso y Balcanes, extendiéndose en los últimos años hacia misiones en África y Asia. Tales misiones han servido, igualmente, como una manera de buscar nuevos socios extrarregionales en el plano político y estratégico, donde destacan los casos de Colombia y Chile, países latinoamericanos que han firmado acuerdos de gestión de crisis con Europa, lo que les permite participar en las misiones desplegadas por ésta región, como lo demuestra la relevante labor colombiana en la Misión Atalanta en Somalía.

Según José Enrique de Ayala, las fuerzas multinacionales de la Unión Europea son un símbolo político de la voluntad de integración de los países miembros en un campo muy sensible, donde las reticencias a ceder soberanía o capacidad de decisión a favor de instancias comunes constituyen todavía un obstáculo fundamental. Según este autor, "será difícil que las naciones europeas acepten 
una integración total de sus unidades militares en unas fuerzas armadas europeas unificadas, al menos a medio plazo" (De Ayala, 2012: 208).

En 2016 la Alta Representante de la Unión para Asuntos Exteriores y Política de Seguridad, Federica Mogherini, presentó al Consejo Europeo una nueva Estrategia Global sobre Política Exterior y de Seguridad de la Unión Europea, actualizando la Estrategia Europea del año 2003. ${ }^{30}$ Este nuevo documento define prioridades, necesidades y medidas de la Unión Europea para hacer frente al escenario actual y futuro de Europa en materia de seguridad y defensa.

Como guía de la PCSD, la Estrategia determina cinco prioridades: la seguridad de la Unión; la resiliencia estatal y social de los vecinos orientales y meridionales de la Unión; la concepción de un enfoque integrado en relación con los conflictos; los órdenes regionales de cooperación, y una gobernanza mundial para el siglo XXI. El texto vería la luz en un momento especialmente complejo, atendida la decisión de Reino Unido de retirarse del mencionado esquema regional.

Haciendo un balance general, es posible plantear que la integración europea representó en su inicio un instrumento fundamental para atenuar y superar fuentes históricas de conflictos entre los países miembros, tras la conflagración mundial, estabilizando el continente $y$, en la actualidad, favoreciendo su inserción internacional con una ingente actividad mediante operaciones de gestión de crisis, aunque es claro que aún sigue primando una estructura intergubernamental, ante la carencia de consenso entre los miembros en variados planos, optando hasta el momento, por conducirse en función de los respectivos intereses nacionales.

No obstante, se observa un alto nivel de integración alcanzado por Europa, espacio de integración que puede calificarse como una comunidad de seguridad madura, donde la guerra se encuentra descartada como medio de relacionamiento entre sus componentes, aunque no lo esté respecto de sus relaciones extrarregionales.

\footnotetext{
${ }^{30}$ Como señala José Enrique de Ayala, el documento de 2003 definía el entorno estratégico en el que se movía la Unión Europea, citando las principales amenazas para Europa, sus intereses esenciales, sus alianzas y las estrategias para enfrentar las amenazas, aunque de un modo genérico, en tanto su propósito era otorgar lineamientos globales a la PESC y la PESD (De Ayala, 2012: 196).
} 
Apreciado desde América del Sur, como señala Levi, esta región no ha pretendido emular las estructuras existentes en la Unión Europea, sino más bien orientarse a la coordinación de políticas de seguridad y defensa que generen un área de paz en la región (Levi, 2012). Si en Europa prima aún la intergubernamentalidad, en América del Sur la flexibilidad es todavía mayor, poniendo la región sus esfuerzos en consensuar posiciones para avanzar en mecanismos que caen en el ámbito, todavía, de la seguridad cooperativa, cuyo objetivo es favorecer un entorno o un ambiente de paz regional.

\section{b) El esquema hemisférico de seguridad y defensa}

Actualmente, las relaciones hemisféricas se estructuran principalmente a través de la OEA, establecida en 1948 en la ciudad de Bogotá, durante la celebración de la IX Conferencia Internacional Americana, en la cual se firmó su Carta constitutiva. En el contexto internacional que otorgaba la recién iniciada Guerra Fría, este mecanismo estuvo guiado en sus orígenes por los principios y valores propugnados por Estados Unidos, ante la pérdida de relevancia internacional de un continente europeo devastado por la Guerra Mundial. Según Vacas y Rodríguez:

"Así las cosas, la política desarrollada por los Estados Unidos en el conjunto de los Estados latinoamericanos quedaba fundamentalmente inspirada por la contención de la expansión del comunismo. Para ello se desplegarán sus esfuerzos en un doble objetivo: por una parte, la seguridad, que frecuentemente puede llevar aparejada una injerencia en los asuntos internos de los Estados; por otra parte, la promoción de ayudas económicas destinadas a evitar la generación de movimientos revolucionarios" (Vacas y Rodríguez, 2013: 22).

En este marco general, la seguridad pasará a constituirse como un elemento vertebrador de las relaciones al interior del continente americano, lo que se tradujo 
en una serie de protocolos y procedimientos adoptados al amparo de la OEA, que determinarán en gran medida las políticas exteriores y de defensa de los países miembros.

Ya a partir del fin de la Guerra Fría, sobre la base de un profundo proceso de reflexión sobre el funcionamiento de la OEA y su aporte a la seguridad hemisférica, considerando los trascendentales cambios que acontecieron en el mundo y el hemisferio desde la década de los noventa, el año 1995 se constituyó la Comisión de Seguridad Hemisférica, que tiene como funciones el estudiar y formular recomendaciones sobre los temas de seguridad del continente, con el objeto de promover la cooperación entre los países y coordinar las actividades de los órganos, organismos, entidades y mecanismos de la Organización, relacionados con los diversos aspectos de la seguridad y defensa en el hemisferio, respetando los mandatos y ámbito de sus competencias.

Bajo el amparo de la OEA, el esquema hemisférico de seguridad y defensa consiste en un conglomerado de organizaciones, tratados y convenciones, así como sus reuniones y conferencias. Entre tales instancias cabe destacar la Comisión de Seguridad Hemisférica, la Comisión Interamericana para el control del abuso de Drogas (CICAD), el Comité Interamericano Contra el Terrorismo (CICTE) y la Convención Interamericana contra la fabricación y tráfico ilícito de Armas de Fuego, Municiones, Explosivos y otros materiales relacionados (CIFTA). En lo tocante particularmente con el ámbito defensivo estratégico existe la Junta Interamericana de Defensa (JID) y su Colegio Interamericano de Defensa (CID). En lo referente a los tratados existentes cabe nombrar el Tratado Interamericano de Asistencia Recíproca (TIAR), el Pacto de Bogotá y el Tratado de Tlatelolco. Por último, están las reuniones de Ministros de Defensa de las Américas y las conferencias de Jefes de las Fuerzas Armadas de los miembros (Raggio, 2012). En este acápite el análisis se concentrará en las iniciativas atingentes al ámbito propio de la defensa.

Primeramente, es necesario señalar que la OEA trabaja en torno a un concepto ampliado de seguridad, que excede con creces aquellos aspectos relacionados exclusivamente con la defensa exterior de los países. Tal definición de seguridad fue establecida en 2003 durante la celebración de la Conferencia Especial sobre 
Seguridad Hemisférica de México, que define un concepto de "seguridad multidimensional", que reconoce que las nuevas amenazas tienen una naturaleza transnacional, donde la seguridad puede ser amenazada por fenómenos políticos, económicos, sociales, ambientales y de salud. Esta conceptualización fue fuertemente influenciada por Estados Unidos.

En lo relativo a la JID, cabe señalar que fue creada antes de la OEA, mediante la Resolución 39 de la Tercera Reunión de Consulta de Ministros de Relaciones Exteriores, celebrada en Río de Janeiro en enero de 1942, constituyéndose como la institución regional de defensa más antigua del mundo. A partir del 2006 se transformó en una entidad de la OEA, congregando actualmente a 27 Estados miembros. Desde sus orígenes, el objetivo fundamental de este mecanismo es estudiar y sugerir las medidas necesarias para la defensa del Continente, en virtud de la situación bélica que se desarrollaba en ese momento a consecuencia de la Segunda Guerra Mundial. En marzo del año 2006 la JID fue incorporada a la OEA, estando entre sus funciones el asesoramiento técnico y consultivo en materias relacionadas con los asuntos militares y de defensa a los miembros de dicha organización. Actualmente la JID está en pleno proceso de migración hacia las estructuras civiles de la OEA, en el marco de la revisión profunda y general que se está llevando a cabo en el sistema interamericano de seguridad y defensa.

Según sostiene Benito Raggio, pese a que el estatuto de la JID es muy limitado, reduciendo su ámbito de acción sólo al asesoramiento, quedando excluida la dirección de ejercicios con fuerzas, la coordinación o la supervisión de actividades, entre otros, esta instancia ha realizado un valioso esfuerzo, propiciando la elaboración de libros blancos de la defensa; trabajando en el área de la cooperación en casos de desastres naturales; las medidas de fomento de la confianza; desminado humanitario; y respondiendo rápidamente a las peticiones de asesoramiento que le han hecho los Estados miembros. Además, su Colegio Interamericano de Defensa realiza una importante labor académica, tanto con los cursos reglados por el programa anual, como con los seminarios y conferencias que se van celebrando a lo largo del año (Raggio, 2012: 362-363).

Cabe señalar que ciertos países del hemisferio han planteado cuestionamientos a la JID, respecto de que ésta no estaría desarrollando un trabajo verdaderamente 
sustantivo para las necesidades estratégicas de los países, no ejerciéndose tampoco un verdadero control civil sobre las decisiones que se adoptan en la instancia. Raggio ha sugerido al respecto, como una manera de enfrentar tales cuestionamientos, que los representantes nacionales en el consejo de delegados de la JID sean verdaderos representantes de sus Ministerios de Defensa respectivos, dando continuidad en el seno de la JID a las aspiraciones, directivas políticas y mandatos de los gobiernos de los países (Raggio, 2012:365).

Gran parte de las críticas sobre la JID se han extendido al sistema interamericano de seguridad y defensa en su conjunto. Los países que más fuertemente han planteado sus impugnaciones son Argentina y los países del llamado eje bolivariano, como Bolivia, Ecuador, Venezuela y Nicaragua. Ello podría explicar la opción que han seguido estas naciones respecto de potenciar, en su lugar, el trabajo que ha venido desarrollando el CDS, en el cual no participan Estados Unidos ni Canadá. Cabe señalar que Brasil ha sido cauto en la materia, impulsando fuertemente el desarrollo del CDS, pero sin optar por un enfrentamiento con la potencia norteamericana.

Complementando este panorama, cabe realizar una breve digresión sobre el TIAR, firmado el año 1947, que incorpora el principio de la seguridad colectiva en el ámbito continental. Según el mencionado documento: "un ataque armado por parte de cualquier Estado contra un Estado Americano, será considerado como un ataque contra todos los Estados Americanos, y en consecuencia, cada una de dichas Partes Contratantes se compromete a ayudar a hacer frente al ataque, en ejercicio del derecho inmanente de legítima defensa individual o colectiva que reconoce el Artículo 51 de la Carta de las Naciones Unidas". Este mecanismo expresaba la concepción estadounidense de seguridad nacional, basada en la denominada teoría de la contención y en la doctrina Truman, que más tarde dio forma a una serie de instrumentos internacionales, como fue el caso de la misma OEA (Calle, 2014: 224-225).

En el marco de las diversas críticas que se han lanzado sobre la real operatividad y relevancia del sistema hemisférico, diversos países que han suscrito el TIAR perciben que este instrumento, más que responder a las necesidades de los países de América Latina, atiende más bien los intereses particulares y 
unilaterales de Estados Unidos, considerándolo una suerte de versión renovada de lo que fue la Doctrina Monroe en el siglo XIX. Más aún, se refieren a su anacronismo y escasa operatividad, en tanto respondería al contexto propio de la Guerra Fría y los intereses del bando occidental, cuando procuraba detener el avance del comunismo en el hemisferio.

EI TIAR ha sido invocado en diversas ocasiones, con resultados dispares, como fue durante el bloqueo a Cuba en el 1962, en la guerra entre Honduras y El Salvador del año 1969 y con ocasión de los ataques terroristas a Estados Unidos el 11 de septiembre de 2001. Sin embargo, un hecho histórico clave, que acentuó las críticas al mismo, fue la Guerra de las Malvinas en 1982, donde quedó demostrada la escasa operatividad del citado mecanismo, que fue bloqueado por Estados Unidos, al mismo tiempo que otros países del hemisferio actuaron en apoyo del Reino Unido y en detrimento de los intereses de Argentina.

Por tales motivos, distintos países han procedido a denunciar dicho acuerdo. Este es el caso de Ecuador (febrero 2014); Venezuela (mayo de 2013); Bolivia (octubre de 2012); Nicaragua (septiembre de 2012); México (septiembre de 2002) y Perú (diciembre de 1991). ${ }^{31}$

Asimismo, cabe referirse al Tratado Americano de Soluciones Pacíficas a los conflictos, denominado más comúnmente como Pacto de Bogotá, establecido el año 1948. Como señala Raggio, este instrumento "recoge la obligación de los Estados miembros de no recurrir al uso de la fuerza y a solucionar los conflictos por la vía de la negociación y el diálogo". También, describe de manera detallada los procedimientos de buenos oficios, mediación, arbitraje, conciliación y procedimiento judicial, a que deben recurrir los firmantes con el objeto de solucionar pacíficamente las controversias surgidas entre ellos. En tal sentido, como señala el mencionado autor, el Pacto obliga a los países a agotar el espacio de la OEA, antes de recurrir al Consejo de Seguridad de Naciones Unidas, contando al presente con una lista importante de reservas interpuestas por varios países de la región (Raggio, 2012: 357).

31 Véase el Comunicado de Prensa de la Cancillería ecuatoriana, disponible en http://www.cancilleria.gob.ec/es/ecuador-denuncia-tratado-interamericano-de-asistenciareciproca-tiar/ Recuperado en octubre de 2015. 
Al momento en que se escriben estas líneas, la realidad continental parece particularmente compleja, ante el anuncio venezolano de retirarse de la OEA, acusándola de intervencionismo. Según ha señalado al respecto la Canciller de Venezuela, Delcy Rodríguez, "el retiro de Venezuela no es coyuntural, tiene que ver con la dignidad de nuestro pueblo y la doctrina bolivariana, que promueve el no intervencionismo y defiende la igualdad soberana de los Estados". ${ }^{32}$

En tal escenario, teniendo en cuenta la antes explicada obsolescencia y debilidad de los mecanismos hemisféricos del ámbito de la seguridad y defensa, los países han optado por avanzar en las respectivas regiones y subregiones, estableciendo instancias de coordinación y cooperación política, que pretenden dotar de una mayor coherencia y estabilidad las relaciones entre los Estados, como es el caso del MERCOSUR y la UNASUR. Como sostiene el profesor Hal Klepak, "Ante la ausencia de una amenaza externa obvia que pueda unir a las naciones del continente americano, claramente el enfoque más regional es el que domina el escenario actual" (Klepak, 2012: 51). La relación entre integración y seguridad en los distintos procesos vigentes a nivel subregional se aprecia en los siguientes apartados.

\section{c) La Comunidad Andina}

La Comunidad Andina (CAN) tiene su origen en el Pacto Andino, surgido a partir del Acuerdo de Cartagena del año 1969, bajo el influjo de las ideas de la CEPAL y con el fuerte impulso del Presidente chileno Eduardo Frei Montalva. Entre sus objetivos, se cuenta el promover el desarrollo equilibrado y armónico de los países miembros en condiciones de equidad, mediante la integración y la cooperación económica y social.

Desde sus orígenes, la CAN ha estado sometida a una serie de incidencias, como fue el retiro de Chile del esquema en 1976 -cuando el país se encontraba bajo el

${ }^{32}$ Véase la nota de prensa "Venezuela anuncia su salida de la OEA", 27 abril 2017. Disponible

http://www.elmundo.es/internacional/2017/04/27/59012433468aeb5c158b4571.html

Recuperado en mayo de 2017. 
régimen militar- y el conflicto entre Perú y Ecuador a mediados de la década de 1990. Actualmente la instancia está caracterizada por la crisis, generada por la desinstitucionalización de la integración; la preferencia de los países miembros por establecer acuerdos bilaterales con países externos al bloque, en desmedro del comercio intrarregional; los roces bilaterales entre sus miembros; así como la salida de Venezuela, ante su opción por integrarse al MERCOSUR. Siguiendo a Russell, es posible sintetizar al respecto que:

"No cabe duda de que diferencias esencialmente políticas determinaron la decisión de Chávez de retirar a Venezuela de la can en 2006, una medida que contribuyó a profundizar su crisis. Razones políticas también pueden rastrearse con facilidad en los acuerdos de libre comercio que firmaron los gobiernos de Colombia y Perú con Estados Unidos, dos decisiones que también afectaron seriamente la CAN, aunque por motivos opuestos a los de Caracas" (Russell, 2011: 134).

La compleja situación descrita se contextualiza en un espacio donde ciertos países demuestran un magro desempeño económico, con una débil inserción externa, cuyo patrón de especialización internacional se basa fundamentalmente en recursos naturales. Es el caso de Bolivia que, pese a las cifras de crecimiento de los últimos años que bordean el $5 \%$ anual -sobre la base de las exportaciones de gas natural-, ${ }^{33}$ todavía registra una elevada dependencia de la Ayuda Oficial al Desarrollo (AOD). Por su parte, Ecuador sostiene parte importante de su economía sobre la base de las remesas de los emigrantes (Grebe, 2004: 10-11). Cabe agregar, asimismo, las periódicas crisis institucionales que se viven en la subregión, donde se aprecian sistemas democráticos débilmente consolidados, así como el conflicto armado de Colombia, que hasta 2016 se constituyó como uno de los problemas políticos y sociales más graves de la región. Respecto de este

${ }^{33}$ Véase al respecto "Bolivia: 3 claves del éxito económico del país que más crece en América del Sur”. Disponible en http://www.bbc.com/mundo/noticias-41702389

Recuperado en noviembre de 2017. 
último, cabe señalar que el escenario colombiano da muestras de estabilización, entrando el país en una fase de postconflicto, luego del acuerdo de paz celebrado entre el gobierno colombiano y las FARC en 2016. En el mismo sentido, cabe destacar que el 25 de enero de ese año se aprobó la Resolución 2261 del Consejo de Seguridad de Naciones Unidas sobre el proceso de paz en Colombia, mediante la cual se establece una Misión Política Especial de observadores no armados, como componente internacional y coordinadora del mecanismo tripartito, bajo el liderazgo de un representante del Secretario General de Naciones Unidas, a petición del Gobierno de Colombia y las FARC, con el objeto de verificar el cese al fuego. Esta Misión terminó sus funciones el 25 de septiembre de 2017 tras 12 meses de mandato. Luego de esta Misión, el 26 de septiembre de 2017 entró en funciones una segunda Misión, con los objetivos de verificar la implementación del proceso de reincorporación política, económica y social de las FARC y la implementación de garantías de seguridad personal y colectiva.

En el terreno de la seguridad y defensa en el área andina, cabe mencionar como antecedente, particularmente el Compromiso Andino de Paz, Seguridad y Cooperación, contenido en la Declaración de Galápagos, de diciembre de 1989. Pero es ya en la Declaración de Santa Cruz de la Sierra del año 2001, donde se aprecian más relevantes lineamientos en este ámbito, por cuanto en ella se acuerda realizar una Conferencia de Ministros de Relaciones Exteriores y de Defensa de los países miembros de la CAN, para examinar una propuesta de reducción de los gastos de defensa (Grebe, 2004: 17).

Destaca principalmente la posterior adopción del Compromiso de Lima, Carta Andina para la Paz y Seguridad, suscrita en junio de 2002. Como señalan Vacas y Rodríguez, el objetivo fundamental del Compromiso de Lima es el establecimiento de la prohibición del uso o la amenaza de la fuerza entre los Estados miembros, de acuerdo a los principios de la misma Carta, y en los que se pone de relieve la existencia de un concepto amplio de seguridad, al otorgarle un enfoque multidimensional coherente con el que se propugna en el ámbito hemisférico (Vacas y Rodríguez, 2013: 62).

Posterior a la Carta de Lima, los países de la subregión suscribieron la Declaración de San Francisco de Quito sobre Establecimiento y Desarrollo de la 
Zona de Paz Andina", adoptada por el XV Consejo Presidencial Andino en julio del 2004. En el evento, asimismo, los países decidieron impulsar el diseño y puesta en marcha de un Programa Andino de Medidas de Fomento de la Confianza y de la Seguridad, que incluye el desarrollo de una metodología estandarizada para la formulación de Libros Blancos en materia de defensa; la implementación de la Política Comunitaria de Integración y Desarrollo Fronterizo; y la enseñanza de una Cultura de Paz e Integración. Según señala Hugo Palma, la declaración de Quito "define una concepción democrática, cooperativa y no ofensiva de la seguridad andina y su espacio geográfico" (Palma, 2012: 303).

Adicionalmente, es relevante agregar la Decisión 587 de la CAN, del año 2004, que establece los lineamientos generales de la Política de Seguridad Externa Común, que busca enfrentar de manera coordinada las amenazas a la seguridad en el bloque y desarrollar y consolidar una Zona de Paz Andina, libre de armas nucleares, químicas y biológicas, promoviendo mecanismos que aseguren la solución pacífica de las controversias, fomenten la confianza mutua y contribuyan a la superación de las situaciones que pudieran generar controversias entre los países miembros (véase Fuentes, 2008: 179-180).

Según señala Palma, dicha Decisión de la CAN establece los objetivos, principios, fundamentos, criterios, mecanismos institucionales, instrumentos operativos, modalidades de acción y agenda, que guían el desarrollo de la Política de Seguridad Externa Común. En consonancia con lo anterior, se encomienda al Comité Ejecutivo de dicha política que, en coordinación con la Secretaría General, elabore un Programa Andino de Medidas de Fomento de la Confianza y de la Seguridad y una propuesta de conformación de una Red Andina de Seguridad,

"como mecanismo institucional de apoyo y asesoramiento en asuntos relacionados a la seguridad y fomento de la confianza, que incluya, entre otros, el diagnóstico de situaciones potencialmente conflictivas, de alerta temprana, de prevención de conflictos y de gestión de crisis, así como de sistemas de información sobre dichas situaciones o sobre conflictos manifiestos, con la participación de representantes de las 
entidades gubernamentales correspondientes, de los partidos políticos, instituciones académicas y de la sociedad civil" (Palma, 2012: 301).

Según sostiene Alfredo Fuentes (2008: 179-180), ex Secretario General de la CAN, los principales instrumentos operativos de la Política de Seguridad Externa común son los siguientes:

-El Plan Andino de Cooperación para la lucha contra las drogas ilícitas y delitos conexos (Decisión 505, del año 2001).

-El Plan Andino para la prevención, combate y erradicación del tráfico ilícito de armas pequeñas y ligeras en todos sus aspectos (Decisión 552, del año 2003).

-Las Normas Andinas para el control de sustancias químicas que se utilizan en la fabricación ilícita de estupefacientes y sustancias psicotrópicas (Decisión 602, del año 2004).

-La cooperación legal, policial y judicial, donde destaca la incorporación al Sistema de Integración Andino de los Fiscales Generales de los países miembros (Decisión 589) y de los Defensores del Pueblo, que apuntan a estrechar la cooperación en la lucha contra el crimen organizado, realizar intercambios en áreas técnicas y de capacitación y colaborar en la puesta en marcha de los sistemas penales en toda la Comunidad.

Como es posible apreciar, hasta el momento, la manera de operacionalizar la Política de Seguridad Externa Común ha sido conducida preferentemente en el ámbito de la seguridad interna -con mecanismos de cooperación en el ámbito de la lucha contra las drogas, el tráfico ilícito de armas pequeñas y ligeras, y cooperación policial y judicial, entre otros- dejando a un lado, hasta el momento, los temas relacionados con el conflicto interestatal. Esta situación puede tener su origen en la preocupación de los Estados por frenar temas como el crimen organizado y el narcotráfico, que se aprecian más urgentes, dejando en un segundo lugar las preocupaciones propiamente interestatales y geopolíticas. En el mismo tenor, Palma señala que: 
"Las preocupaciones de seguridad de las sociedades latinoamericanas y andinas, están menos referidas a las posibilidades de conflicto clásico que sería anacrónico, incomprensible, ilegal y absurdo y se focalizan cada vez más en los problemas de seguridad de las personas e instituciones (Palma, 2012: 308).

En el terreno de lo propiamente estratégico y militar, destaca el relacionamiento entre Perú y Ecuador, que luego del conflicto de mediados de los noventa, han avanzado de manera sostenida hacia la cooperación bilateral. A este respecto, destacan, entre otros, la suscripción de los acuerdos de paz de 1998 y los programas conjuntos de desarrollo e integración fronteriza, que "se han expandido con innegable beneficio para los residentes de ambos lados de la frontera y también se han multiplicado las medidas de fomento de la confianza entre las Fuerzas Armadas" (Palma, 2012: 306).

Junto con ello, es necesario también recalcar la existencia del Mecanismo de Consulta y Coordinación a nivel de Ministros de Relaciones Exteriores y de Defensa de Perú y Bolivia, así como las reuniones binacionales sobre medidas de confianza mutua y seguridad y las rondas de conversaciones entre los Altos Mandos de las fuerzas armadas de ambos países; y las reuniones entre el Estado Mayor de la Defensa del Brasil y el Comando Conjunto de las fuerzas armadas de Perú, entre otras instancias de diálogo bilateral entre los países del ámbito andino. No obstante, cabe sostener, junto a Adrián Bonilla, que hasta ahora, si bien la CAN plantea una retórica común en temas de política exterior, aún no ha sido capaz de establecer mecanismos e instrumentos institucionales que permitan la generación de un espacio de seguridad cooperativa, lo que puede estar en la base de la preferencia de los países por avanzar en el marco sudamericano, así como en mecanismos de corte bilateral. Además, según Bonilla:

"...es preciso enfatizar el hecho que a pesar de haber desempeñado un rol pionero en la integración subregional a partir del establecimiento del Pacto Andino a finales de la década de 
1960, la CAN no ha resultado efectiva para impulsar acuerdos viables en materia política, económica y de seguridad" (Bonilla, 2010: 224).

Actualmente la CAN se encuentra en un profundo proceso de revisión, lo que desde luego ha afectado sus posibilidades de aportar de manera eficaz a los temas relacionados con la cooperación en defensa entre sus miembros.

\section{d) EI MERCOSUR}

Desde comienzos de los años noventa se planteó en el Cono Sur una tendencia a la convergencia en materia de seguridad e integración, liderada por Brasil y Argentina. Luego de la denominada década perdida, esta convergencia se originó en la idea de que una integración económica no podía ser sostenida en el largo plazo, sin alcanzar acuerdos en el plano estratégico y de seguridad. Para ello, debían desactivarse las percepciones de amenaza convencionales a la seguridad de los Estados, que persistían desde la época de las dictaduras militares. En tales circunstancias, es evidente que el MERCOSUR fue creado por razones estratégicas, que superan una perspectiva meramente comercial, siendo actualmente, al decir de Mercedes Botto, “...la experiencia de integración latinoamericana de mayor desarrollo y consolidación institucional" (Botto, 2015: 18).

Desde un prisma político, hacia la segunda mitad de la década de los ochenta, el MERCOSUR tuvo como antecedente una serie de encuentros, declaraciones y acuerdos entre los entonces presidentes Raúl Alfonsín y José Sarney, que encabezaban los primeros gobiernos del Cono Sur que vivían procesos de transición a la democracia. De este modo, se desarrollaba en la subregión una tendencia integradora en lo económico y comercial, que tuvo como correlato el reforzamiento de los mecanismos e instancias de diálogo y concertación política.

En otras palabras, el MERCOSUR fue antecedido por la relevante la cooperación planteada entre Argentina y Brasil desde mediados de la década de los ochenta, cuando ambos países vivían procesos de transición democrática, en las áreas 
energética y nuclear, donde destaca la creación de la Agencia Brasileña-Argentina de Contabilidad y Control de Materiales Nucleares (ABACC) (Gonçalves, 2013). EI bloque nace con el Tratado de Asunción, suscrito en Montevideo el año 1991. Su objetivo es crear un mercado común, sobre la base de la libre circulación de bienes, servicios y factores productivos entre los países miembros, el establecimiento de un arancel externo y la adopción de una política comercial común, la coordinación de políticas macroeconómicas y sectoriales entre los Estados partes y la armonización de las legislaciones en pos del fortalecimiento del proceso de integración.

De tal manera, las políticas de enfrentamiento en el Cono Sur, la competencia por el liderazgo militar y las diferencias y conflictos limítrofes que predominaban en el área hasta mediados de los ochenta, fueron moderadas o desplazadas por una tendencia creciente hacia la cooperación, como la mejor opción para construir una ambiente de paz y seguridad en la subregión, y como una condición esencial para impulsar la inserción internacional de los países. Ello posibilitó un cambio fundamental en las relaciones entre Argentina y Brasil, lo que permitió el avance en el proceso de integración.

En consecuencia, la integración no sólo se concebía desde una perspectiva meramente económica y comercial, sino que se consideró el factor político como una condición decisiva. De hecho, según Fred Bergsten (1996), de manera similar a la Unión Europea, que en sus orígenes buscaba poner término a la histórica rivalidad entre Francia y Alemania y dotar de paz a Europa luego de las terribles consecuencias derivadas de la Segunda Guerra Mundial, entre otros ámbitos, el MERCOSUR buscaba poner fin a la carrera armamentista y a la competencia estratégica entre Argentina y Brasil, incluida su dimensión nuclear.

De esta manera, tras el fin de la Guerra Fría, Brasil y Argentina asumían políticas exteriores de inserción internacional y establecian el MERCOSUR como una estrategia para adaptarse a las nuevas condiciones del escenario mundial, estando el acercamiento argentino-brasileño contextualizado por la aceleración del proceso de globalización, la convergencia entre los países del Cono Sur en lo tocante a las políticas económicas y las transiciones hacia la democracia, en el marco de la "tercera ola democrática". Como recalcan Sanahuja y Verdes- 
Montenegro, el proceso integrativo descrito fue complementado el año 1991, cuando Argentina, Brasil y Chile —con la posterior incorporación de Uruguay, Bolivia, Ecuador y Paraguay - adoptaron el "Compromiso de Mendoza", que prohíbe la producción, desarrollo, almacenamiento, adquisición y uso de armas de destrucción masiva y compromete a los firmantes a suscribir la Convención de Armas Químicas (Sanahuja y Verdes-Montenegro, 2014: 492).

Durante los últimos años, diversas críticas se han lanzado sobre el MERCOSUR y su funcionamiento. Entre ellas, se cuentan las diatribas de los socios menores del bloque, que cuestionan los reales beneficios de su pertenencia al proceso de integración, aduciendo que este no estaría respondiendo a sus intereses. llustradora resultó en tal sentido la frase pronunciada en julio de 2009 por el entonces candidato del Frente Amplio a la presidencia de Uruguay, José Mujica, quien sostuvo que el MERCOSUR "anda rengo y a la miseria". Entre otras, las dificultades del bloque se relacionan con la necesidad de reducir las asimetrías y disparidades entre los miembros, el proteccionismo, así como con la vulnerabilidad externa de algunos de ellos.

Destacan por ejemplo, las pugnas suscitadas entre Brasil y Argentina por las medidas proteccionistas aplicadas por este último, que tuvieron como correlato la eliminación, por parte del primero, de las licencias anticipadas para ciertos productos -como manzanas, peras, uvas y vinos- importados desde el país del sur. A ello se suman las dificultades para lograr un acuerdo en las dilatadas negociaciones entre la Unión Europea y el MERCOSUR, que se vieron fuertemente afectadas por la decisión argentina de expropiar el $51 \%$ de las acciones de la petrolera YPF, en manos de la empresa española Repsol. Asimismo, destaca últimamente la suspensión de Venezuela del bloque, exigiendo los miembros un "proceso de transición política para restaurar el orden democrático" en dicho país. ${ }^{34}$

\footnotetext{
${ }^{34}$ Véase "Mercosur decide la suspensión política de Venezuela y consuma el aislamiento de Maduro". El País, 6 agosto 2017. Disponible en https://elpais.com/internacional/2017/08/05/actualidad/1501946948 015024.html Recuperado en noviembre de 2017.
} 
Pero las dificultades del MERCOSUR son las dificultades que enfrenta la integración regional en su conjunto, donde predomina la falta de un liderazgo definido, el nacionalismo, la falta de consenso, y los discursos altisonantes de las autoridades políticas, que no van de la mano de los resultados esperados de tal proceso (Malamud, 2009). Por lo demás, el escenario crecientemente multipolar y descentralizado que se aprecia actualmente en el mundo, tiene características bastante distintas al que vio surgir al MERCOSUR en los albores de la década de los noventa, que coincidía con el contexto del fin de la Guerra Fría, la "resurrección" de las Naciones Unidas y la transitoria hegemonía estadounidense (Pinheiro, 2012:13).

Desde sus inicios, el MERCOSUR tuvo un carácter visiblemente económico, que desde mediados de la década de los noventa comenzó a evidenciar problemas en torno a las dificultades de remover las barreras arancelarias, las políticas económicas internas que afectaban la competencia, así como el trabajo de hacer efectiva la aplicación de las normas del bloque.

Según sostiene Natividad Lorenzo (2006), desde su creación en 1991 y hasta 1998, el MERCOSUR evidenció importantes logros en la esfera comercial. En esta fase, se logró liberalizar la totalidad de los productos comprometidos para esta etapa y aplicar un arancel externo común al $88 \%$ del universo arancelario de la subregión. Estos avances atrajeron capitales y aumentaron la inversión extranjera directa, creando un clima propicio para la integración. Sin embargo, la crisis económica y financiera que sufrió la región hacia fines de la década de los noventa, marcaron el fin de esta etapa favorable, iniciándose un nuevo periodo donde priman los intereses nacionales en las relaciones al interior del bloque, estancándose los flujos del comercio intrarregional, a lo que se une la pérdida de confianza de los inversores extranjeros y la fuga de capitales (Lorenzo, 2006: 2). En la actualidad, ante los obstáculos que ha debido enfrentar el MERCOSUR en los asuntos comerciales, y con el objeto de otorgarle un mayor peso político y contrarrestar el peso que están teniendo otras instancias en la región, se está buscando ampliar su área de influencia, como lo evidencia la incorporación de Guyana y Surinam como miembros asociados. 
De tal modo, en el terreno comercial, diversas problemáticas han marcado el funcionamiento del MERCOSUR. Entre las críticas que se han planteado al bloque, está el que dicha instancia carece de una dimensión comunitaria y supranacional, caracterizándose por una estructura orgánica escueta y de carácter meramente intergubernamental. En la misma línea, Lorenzo señala que el MERCOSUR se caracteriza por ser un proyecto de escasa calidad institucional, poca disciplina de los miembros, falta de incorporación de normas, reuniones de bajo nivel con escasa calidad técnica y falta de orden interno. Esto ha impulsado a los países pequeños a buscar nuevas opciones de asociación comercial; a ello se suma la falta de una visión común y de un liderazgo definido en el proceso de integración, ante la omisión del rol natural que debiera ejercer Brasil, más empeñado en su posicionamiento como potencia emergente en otras instancias internacionales (Lorenzo, 2006).

Sin embargo, las vicisitudes económicas y comerciales del MERCOSUR han encontrado como contrapartida una creciente interrelación en otras áreas, como la tecnología, ciencia, educación, migraciones y aspectos vinculados con la cooperación estratégica y militar (Molina, 2000: 28; Pey \& Riquelme, 2007). En el ámbito sudamericano, y más allá de las críticas que se han hecho sobre los modestos efectos del MERCOSUR en materia de integración comercial, lo cierto es que el bloque ha logrado expresar un relativo éxito en el ámbito político y social, donde ha ampliado fuertemente su agenda, incorporando variadas temáticas y realizando aportes destacables en el terreno de la seguridad y defensa. Considerando lo anterior, Mercedes Botto plantea que el bloque, a diferencia de otros procesos regionales, ha sido el que ha alcanzado "... mayores avances en términos de ampliación de agendas y de inclusión de actores" (Botto, 2015: 15).

Es decir, las dificultades y estancamientos del MERCOSUR en el área comercial no han mermado una de las principales fortalezas del bloque, como lo es su notable sentido político, que ha implicado la promoción de un ambiente de paz y estabilidad en el Cono Sur. En este orden de ideas, Gabriel Gaspar señala que, si bien han existido importantes diferencias entre los países del MERCOSUR y sus asociados, apreciándose en el terreno económico ciertas vicisitudes de las 
economías nacionales, no ha ocurrido lo mismo en el ámbito político, donde los logros de la concertación son evidentes. De esta manera, el "MERCOSUR político" mostraría más logros que el "MERCOSUR económico", cuestión que se expresaría en los temas de seguridad. Es decir, más allá de las dificultades que se aprecian en su desempeño económico, lo cierto es que el MERCOSUR ha sido particularmente exitoso en su contribución a la consolidación democrática y al mantenimiento de la paz en el Cono Sur (Gaspar, 2003:31).

La institucionalización de la cooperación del ámbito político, en el marco del bloque, vivió importantes avances el año 1998, a partir de la Cumbre de Presidentes del MERCOSUR, realizada los días 24 y 25 de julio, donde participaron los mandatarios de los Estados miembros plenos y de los Estados asociados. En el evento se firmó el Protocolo de Ushuaia, que instituyó la denominada cláusula democrática. Este instrumento ha sido relevante para el favorecimiento de la estabilidad en el Cono Sur, en el entendido que las democracias tienden a la paz entre ellas.

En la esfera de la seguridad y defensa, es necesario señalar que es en el marco de esta instancia subregional donde cobró mayor fuerza la idea de establecer una Zona de Paz, teniendo como base los acercamientos que se daban entre Brasil y Argentina. Bajo este influjo, en julio de 1998 se suscribió la Declaración Política del MERCOSUR, Bolivia y Chile como Zona de Paz, que representa una manifestación relevante de que la paz se constituía como un elemento fundamental para la continuidad y desarrollo del proceso de integración.

Teniendo como base este acuerdo, entre los países del bloque la cooperación en defensa se dinamizó importantemente, lo que se expresó en que las hipótesis de conflicto dieron paso a políticas de defensa cada vez más cooperativas, lo que atizó sustancialmente las relaciones internacionales y la confianza mutua, en desmedro de las tradicionales percepciones de amenaza.

A lo largo de su desarrollo, el acercamiento de los países que participan del MERCOSUR -ya sea como miembros plenos o asociados- se ha expresado, en el terreno estratégico, en una fluida cooperación bilateral de las políticas de defensa, que ha sido particularmente evidente en las relaciones entre Brasil y Argentina y 
entre éste y Chile, lo que incluso ha llevado a algunos analistas a reflexionar en torno a una suerte de reedición del $\mathrm{ABC}$ de principios del siglo $\mathrm{XX}$.

Como señala Flemes, en el terreno de la cooperación militar, el acercamiento entre los miembros se ha traducido en conferencias, reuniones, ejercicios conjuntos, cooperación técnica y programas de intercambio entre las academias de las respectivas fuerzas armadas, siendo el centro de gravedad de esta fluida cooperación el relacionamiento argentino-brasileño (Flemes, 2004). Especialmente destacable resultan las reuniones que comenzaron a celebrarse a partir del año 2001 entre los Comandantes en Jefe de los Ejércitos del MERCOSUR durante las cuales se trataron temas como el mejoramiento de la interoperabilidad, medidas de cooperación e integración en defensa, las labores en la MINUSTAH y mecanismos de respuesta ante situaciones de desastres naturales, entre otros. Una versión similar de estas reuniones se replicó entre el 11 y 13 de octubre de 2016 en la ciudad de Foz de Iguazú, con la celebración de la Conferencia de Comandantes de Ejércitos del Cono Sur, organizada por el Ejército de Brasil, que contó con la participación de las instituciones castrenses de Argentina, Chile, Paraguay y Uruguay. En la instancia se abordaron temáticas como los ámbitos de empleo en seguridad y defensa, respetando las individualidades de las legislaciones y políticas de defensa de cada país; la promoción de los intercambios y programas de cooperación que permitan profundizar la aproximación entre los ejércitos participantes, estrechar los lazos de amistad e incrementar medidas de confianza mutua entre las fuerzas; y el incremento de la confianza mutua y la cooperación multilateral entre los países del Cono Sur. ${ }^{35}$ En esta línea, ya en el año 2002 Marcos Robledo y Francisco Rojas sostenían lo siguiente:

"...los países que participan en el proceso de desarrollo del régimen subregional de integración han ingresado en una etapa de cambio estratégico que, a pesar de las divergencias que persisten,

35 Información en tal sentido, puede encontrarse en https://dialogoamericas.com/es/articles/southern-cone-governments-join-forces-fight-transnational-crime Recuperado en marzo de 2017. 
origina una clara tendencia hacia el desarrollo de regímenes cooperativos de seguridad y defensa, siendo esperable que al no visualizarse modelos alternativos, la cooperatividad se consolide y profundice" (Robledo y Rojas, 2002: 18).

En suma, los aportes pioneros del MERCOSUR en materia de seguridad y defensa pueden apreciarse como la base de los futuros lineamientos que exhibe la región de América del Sur en la correlación entre integración y seguridad, donde destaca el desarrollo que demuestra actualmente el Consejo de Defensa Suramericano. O sea, como núcleo duro de la integración, el MERCOSUR se presenta como el origen de la comunidad de seguridad que se aprecia actualmente a nivel sudamericano. Estas distintas iniciativas, y especialmente los avances realizados en el contexto del MERCOSUR, han servido como base o caja de resonancia de los avances apreciados en el ámbito sudamericano. Por su enorme tamaño relativo, Brasil ha servido como nexo entre las diferentes instancias subregionales y su proyección regional.

Según sostienen Flemes y Radseck (2009:18), el MERCOSUR y la UNASUR son las estructuras claves que impactan la gobernanza regional en el ámbito de la seguridad. EI MERCOSUR ampliado, con la entrada de Venezuela como miembro pleno, es geográficamente congruente con UNASUR. Ambas instancias han servido igualmente como un marco para generar posiciones políticas convergentes en la región, tanto en su participación en organismos multilaterales, como en las relaciones con actores extrarregionales, como fue el caso del apoyo que ambas instancias expresaron a Argentina en su reivindicación de las Islas Malvinas.

La declaración del MERCOSUR como Zona de Paz servirá como antecedente para que en la primera Reunión de los Presidentes de América del Sur, celebrada entre los días 31 de agosto y 1 de septiembre de 2000 en Brasilia, se acordara crear una Zona de Paz Sudamericana. En seguimiento de ello, los Ministros de Relaciones Exteriores de los países de la CAN, el MERCOSUR y Chile, reunidos en La Paz en julio de 2001, formularon las bases para un proyecto sobre la Creación de una Zona de Paz y Cooperación Sudamericana. Luego, durante la segunda Reunión de los Jefes de Estado Sudamericanos, celebrada en Guayaquil 
en julio de 2002, los Presidentes acordaron la Declaración sobre la Zona de Paz Sudamericana.

Como se verá más adelante, los mencionados documentos, así como la posterior declaración de la UNASUR de la reunión extraordinaria de Jefes de Estado y de Gobierno, celebrada en San Carlos de Bariloche en agosto de 2008 -que proclamó nuevamente a Sudamérica como Zona de Paz- son antecedentes relevantes para contextualizar la decisión de constituir el Consejo de Defensa Suramericano, en diciembre de 2008.

\section{e) EI ALBA}

Originalmente denominada Alternativa Bolivariana para los Pueblos de Nuestra América (ALBA), esta iniciativa venezolana surge en 2004 luego de diversos eventos, entre los que destaca el Acuerdo de La Habana de abril de 2006, que integra a Venezuela, Cuba, Bolivia, Nicaragua, Dominica, Ecuador, San Vicente y Las Granadinas y Antigua y Barbuda (Honduras ha dejado de formar parte). El ALBA surgió como una respuesta al Área de Libre Comercio de las Américas (ALCA), que Estados Unidos impulsó desde 1994, con el fin de favorecer la liberalización comercial desde "Alaska a Tierra del Fuego". La instancia impulsada por el Presidente venezolano Hugo Chávez busca reemplazar una supuesta doctrina hemisférica, propugnada por la potencia norteamericana, en tanto no respondería a las necesidades y objetivos de la región de América Latina, poniendo un mayor énfasis en lineamientos cercanos al tercermundismo expresado, entre otros, en un fuerte activismo en el seno del Movimiento de Países No Alineados (NOAL), así como en la Organización de Países Exportadores de Petróleo (OPEP). A partir de la VI Cumbre Extraordinaria de Maracay, del año 2009, el ALBA pasó a llamarse Alianza Bolivariana para los Pueblos de Nuestra América, denotando su nuevo objetivo estratégico y geopolítico.

Desde sus arranques, el ALBA se ha propuesto como objetivo de la integración el combate al imperialismo. En este sentido, Sonia Alda plantea que "la integración regional se justifica en tanto principal instrumento para lograr una segunda y 
auténtica independencia de la dominación imperial. Un aspecto vertebral que define esta propuesta y la distingue, entre otros aspectos, de la UNASUR" (Alda, 2012a: 376). Bajo ese supuesto se justifican las propuestas de integración energética, financiera y de comunicación impulsadas al interior del ALBA, como son Petrocaribe, el Banco del Sur y teleSur, respectivamente (Alda, 2012b: 250). Esta mirada ha llevado a los países pertenecientes al ALBA a mantener un fuerte signo soberanista, poniendo un especial énfasis en su ataque a concepciones liberales en el plano del derecho internacional y el multilateralismo, como son aquellas nociones vinculadas a la Seguridad Humana y la Responsabilidad de Proteger.

Con un discurso fuertemente antiimperialista y contrario a las tendencias de la globalización económica, Venezuela ha sido el portador de un discurso poderosamente apegado a las concepciones más clásicas sobre la soberanía y la autodeterminación, como lo demuestra el siguiente fragmento del discurso de Hugo Chávez al inicio de la cátedra Simón Bolivar, en la Universidad Nacional de Brasilia, el 6 de mayo de 1999:

"O nos unimos todos y nos reintegramos en un mundo que es uno solo, o seremos arrollados por la globalización nefasta, por esa globalización que impone, que domina, que orienta, que pretende que el mundo sea unipolar" (En Aranda, 2013: 2010).

Respecto de la Responsabilidad de Proteger en particular, el ex mandatario venezolano fue enfático, durante la apertura del $60^{\circ}$ período de sesiones de la Asamblea General de Naciones Unidas -celebrada entre los días 14 y 16 de septiembre de 2005 en Nueva York- en que:

"... resulta imprescindible un nuevo orden político internacional, no permitamos que un puñado de países intente reinterpretar impunemente los principios del Derecho Internacional para dar cabida a doctrinas como la Guerra Preventiva, jvaya que nos amenazan con la guerra preventiva!, y la llamada ahora 
Responsabilidad de Proteger, pero hay que preguntarse quién nos va a proteger, cómo nos van a proteger... estos son conceptos muy peligrosos que van delineando el imperialismo, van delineando el intervencionismo y tratan de legalizar el irrespeto a la soberanía de los pueblos, el respeto pleno a los principios del Derecho Internacional y a la Carta de las Naciones Unidas deben constituir, señor Presidente, la piedra angular de las relaciones internacionales en el mundo de hoy, y la base del nuevo orden que propugnamos." ${ }^{36}$

El ALBA fue impulsado por Chávez, como una manera de reforzar la autodeterminación y la soberanía de los pueblos, pretendiendo configurarse como una opción frente a las políticas económicas y financieras propugnadas desde Estados Unidos y ciertos organismos internacionales, como el Banco Mundial y el Fondo Monetario Internacional. Conjuntamente con lo anterior, dicha instancia se constituye como una reacción contra los supuestos del Regionalismo Abierto, impulsado desde los noventa desde la CEPAL, apreciados como propios de un contexto neoliberal de desregulación estatal y propugnando, en su lugar, diversas conjeturas ideológicas susceptibles de entender como propios de una etapa que se ha dado en denominar como post liberal, de manera concordante con la postura del socialismo del siglo XXI, impulsado por el fallecido Hugo Chávez.

Siendo la ideología un fuerte elemento cohesionador en el ALBA, esta misma situación se ha presentado como una de sus más importantes debilidades, al condicionar la membrecía de los Estados al alineamiento ideológico de los gobiernos, impidiendo una eventual expansión. Ello fue particularmente visible en el caso de Honduras, tras el derrocamiento del Presidente Manuel Zelaya, a mediados de 2009. Además, como señala Sonia Alda, la personificación del proyecto en torno a la figura del mandatario venezolano ha sido un elemento fundamental para explicar su origen, concreción y sucesiva incorporación de diferentes miembros, pero esta identificación entre el líder y el proyecto no deja de

36 La intervención completa se encuentra disponible en http://www.aporrea.org/actualidad/a16699.html Recuperado en enero de 2014. 
ser, al mismo tiempo, una debilidad (Alda, 2012a: 390), tal cual lo demuestra la alicaída dinámica que ha adquirido la iniciativa tras la muerte de Chávez.

De hecho, luego de la muerte de dicho mandatario, el ALBA lucha por mantener protagonismo regional, sobre todo en consideración de los avances que evidencia la Alianza del Pacífico, un intento de integración comercial identificado con el libre mercado. Del mismo modo, el liderazgo de Chávez no ha encontrado un sucesor en el ALBA, lo que se ha expresado en la pérdida de dinamismo de la iniciativa bolivariana (Malamud, 2013).

En una entrevista realizada al ex diplomático venezolano y actual académico de la Universidad de Georgetown, profesor Ángelo Rivero, éste fue claro en señalar que el liderazgo carismático de Chávez nunca logró consolidarse ni institucionalmente ni en un sistema económicamente viable y alternativo a la dependencia del petróleo, lo que ha afectado fuertemente la viabilidad en el tiempo del proyecto ALBA. Además, según Rivero, el carácter ideológico de este esquema también se ha presentado como fuente de debilidades, en tanto no ha permitido atraer una mayor diversidad de miembros a dicho bloque. Por último, tampoco Maduro ha dado muestras de poder replicar el liderazgo chavista, en un contexto actual marcado por el auge de gobiernos de derecha en América Latina (muy distinto al contexto político que enmarcó el activismo regional de Chávez, que en su momento contó con apoyos, por ejemplo, desde Argentina, Brasil y Ecuador), una sensible baja del precio internacional del petróleo y un notorio vuelco hacia adentro del gobierno de Venezuela, aquejado de una férrea crisis política y económica. ${ }^{37}$

En lo tocante al ámbito estratégico militar, cabe señalar que este es un punto todavía incipiente en el marco del ALBA, no existiendo tampoco referencias a esta temática en sus textos fundacionales. Según sostiene María Cristina Silva (2011), no existen dentro de esta iniciativa acabados acuerdos multilaterales de cooperación militar o de defensa regional. Es recién en la VII Cumbre del ALBA, celebrada en octubre de 2009 en Cochabamba, cuando se gestó una primera iniciativa para institucionalizar la seguridad en el ALBA, al decidirse la

${ }^{37}$ Entrevista realizada el 21 de junio de 2017 en la Universidad de Georgetown, Washington D.C. 
conformación de un Comité Permanente de Soberanía y Defensa, que formaría parte del Consejo Político del ALBA.

El Comité tiene como objetivos "la definición de una Estrategia de Defensa Integral Popular Conjunta y la constitución de una Escuela de Dignidad y Soberanía de las Fuerzas Armadas". Pero como plantea Sonia Alda, desde la VII Cumbre los avances no han sido muy significativos en esta línea. Con una mirada crítica al respecto, Alda sostiene que:

"La misma resolución de la Cumbre contemplaba la elaboración de una Estrategia de Defensa Integral Popular Conjunta, que sin embargo tampoco no ha sido elaborada. No parece que este paso vaya a ser el más sencillo ya que, como ha sido mencionado, no todos los países miembros comparten una estrategia y una doctrina común" (Alda, 2012a: 389).

En este complejo marco, y como una manera de mantener visibilidad a nivel interno y regional, en julio de 2013 Evo Morales propuso avanzar hacia la constitución de una OTAN Bolivariana, considerando la apuesta del Presidente colombiano Juan Manuel Santos de fortalecer las relaciones entre su país y la OTAN. Una idea similar había sido planteada por Hugo Chávez en diversas ocasiones. En el año 2000 habló de la idea de crear una Organización del Tratado del Atlántico Sur (OTAS); en 2006 declaró ante diversos presidentes sudamericanos que "Debe llegar el día en que el Mercosur tenga una organización de defensa donde vayamos fusionando las Fuerzas Armadas de nuestros países y donde enmarquemos una estrategia propia de seguridad, soberanía y defensa". También, poco antes del establecimiento del Consejo de Defensa Suramericano, recordó que él había propuesto con anterioridad la creación de una OTAS. Asimismo, a principios de 2008 propuso desarrollar un "ALBA militar", que planteaba una alianza estratégica, que incluía componentes relacionados con el uso de la fuerza. Y lo volvió a señalar en el seno del ALBA, durante la VII Cumbre de octubre de 2009, cuando postuló la necesidad de crear una alianza militar defensiva (véase Alda, 2012a: 379-380). 
Tales propuestas iban de la mano de un llamado a la defensa colectiva de los miembros, donde "cualquier ataque contra un miembro de la Alianza debe tomarse como un ataque contra la Alianza en pleno" (Alda, 2012b: 253), tal cual lo señalaron Chávez y el Presidente de Nicaragua, Daniel Ortega, durante el programa Aló Presidente en enero de 2008, cuando el primero planteó que:

"Debemos trabajar en el ALBA para conformar una estrategia conjunta e ir articulando nuestras fuerzas armadas...porque el enemigo es el mismo y si se meten con uno de nosotros se meten con todos...y responderemos como uno solo". (En Alda, 2012b: 254).

Lo antes señalado, asimismo, va de la mano de un fuerte cuestionamiento a la institucionalidad hemisférica de seguridad y defensa, articulada desde la OEA, apreciada como otro mecanismo de predominio imperial estadounidense. Según plantea Sonia Alda, para el ALBA resulta imprescindible "...sustituir la doctrina de seguridad hemisférica y sus hipótesis de conflicto propuestas por Estados Unidos, ya que es ajena a las necesidades de seguridad de la realidad latinoamericana. Esta doctrina de seguridad propia ha de estar basada en la unidad y la solidaridad" (Alda, 2012b: 253). Lo antes expuesto llevó a los países del ALBA a anunciar su retiro de la JID, el 6 de junio de 2013, durante una rueda de prensa ofrecida en el marco del $43^{\circ}$ período de sesiones de la Asamblea General de la mencionada organización, celebrada en la ciudad de Antigua, Guatemala. En la ocasión, el entonces Canciller de Ecuador, Ricardo Patiño, señaló en tal sentido que "no tiene ningún sentido" seguir perteneciendo a la JID, que "...ha hecho de nuestros Ejércitos y policías apéndices de los intereses norteamericanos" y solo ha servido "para formar gente para vigilarnos y controlarnos". ${ }^{38}$

Desde la óptica de Chávez, las fuerzas armadas de la región podrían realizar una serie de actividades en apoyo del desarrollo de la región, lo que incluiría la

38 "Países del ALBA anuncian retiro de la JID de OEA". Informador, 6 junio 2013. Disponible en http://www.informador.com.mx/internacional/2013/463040/6/paises-de-albaanuncian-retiro-de-la-jid-de-oea.htm Recuperado en abril de 2017. 
navegación del Río de la Plata, el Paraná, el Amazonas y el Orinoco, lo que crearía una "arteria" en el continente, que contribuiría decisivamente al proceso de integración. De tal modo, las fuerzas armadas se convertirían en motores de desarrollo, facilitando la comunicación y "un proyecto de desarrollo a los campesinos, proyectos agrícolas, proyectos industriales, científicos, de soberanía y de seguridad y defensa". En suma, desde esta óptica, "los militares serán punta de lanza en crear polos de desarrollo para hacer posible uno de los principales objetivos del ALBA: lograr el desarrollo endógeno" (En Alda, 2012a: 382). Tales propuestas de Chávez tendrían como base la extensión, al nivel regional, de la unión cívico-militar articulada en Venezuela, la cual justificaría la dedicación del instrumento armado al desarrollo y la implicación de la ciudadanía en la defensa nacional, teniendo como norte la lucha antiimperialista, a la manera de una estrecha alianza entre el pueblo y las fuerzas armadas (Alda, 2012b: 244).

Las ideas propugnadas en su momento por Chávez no han tenido los efectos esperados, por cuanto es poco lo que se ha avanzado en materia de integración en defensa en el ALBA, lo que puede explicarse, en otros elementos, en las dificultades de aunar visiones entre países con preocupaciones distintas, asimétricos y geográficamente separados. No obstante, ha sido en Bolivia donde tales ideas han calado más fuertemente. De hecho, el Presidente Evo Morales, el 17 de agosto de 2016, en concordancia con el día de la bandera de Bolivia, inauguró la Escuela Antiimperialista para las Fuerzas Armadas Juan José Torres, con el objeto de servir "para la defensa del pueblo y no del imperio", según consignó el Mandatario en el discurso de apertura de la ceremonia de inauguración, que contó con la presencia de delegaciones de Venezuela, Ecuador y Nicaragua. En palabras de Morales:

"Con esta escuela queremos construir un pensamiento anticolonial y anticapitalista que vincule a las fuerzas armadas con los movimientos sociales y así contrarrestar la influencia de la Escuela de las Américas, que ha visto desde siempre a los indígenas como a enemigos internos. Se trata de contrarrestar el dominio político, 
cultural, económico y tecnológico del imperialismo estadounidense". ${ }^{39}$

En línea con lo señalado por Morales, su Ministro de Defensa, Reymi Ferreira, planteó al respecto que:

"En estos 10 años de gobierno popular, las fuerzas armadas no han salido a matar ni a reprimir ni a masacrar, han cumplido su esencia constitucional en una nueva orientación y eso se pretende con una escuela de la vida y no para la muerte, en la que se adoctrinaban nuestros cuadros militares". ${ }^{40}$

La Escuela, que cuenta con un presupuesto de 5,5 millones de bolivianos para la gestión 2017, tiene su sede en Santa Cruz, contando con materias como teoría del imperialismo, geopolítica del imperialismo, geopolítica de los recursos naturales, estructura social boliviana y estructura jurídica institucional, entre otros, impartidas por instructores de Cuba, Ecuador y Venezuela. ${ }^{41}$

En línea con lo anterior, el 7 de agosto de 2017, con ocasión del $192^{\circ}$ aniversario de las Fuerzas Armadas de Bolivia, se llevó a efecto el Primer Desfile CívicoMilitar, que reemplaza la anterior Parada Militar en ese país. En el evento participaron unos 10.000 efectivos militares y 20.000 civiles, como expresión de

39 "Evo Morales inaugura escuela para formar militares antiimperialistas". La Tercera, 17 agosto 2016. Disponible en http://www.latercera.com/noticia/evo-morales-inauguraescuela-para-formar-militares-antiimperialistas/ Recuperado en agosto de 2016.

40 "El gobierno busca desterrar la doctrina imperialista de las FFAA". Página Siete, 16 agosto 2016. Disponible en http://www.paginasiete.bo/nacional/2016/8/16/gobierno-buscadesterrar-doctrina-imperialista-ffaa-106444.html Recuperado en agosto de 2016.

${ }^{41}$ Entre otras notas de prensa, véase "Gobierno destinará Bs 5,5 millones a Escuela Antiimperialista para gestión 2017”. La Razón, 22 julio 2016. Disponible en http://www.noticiasbolivia.net/gobierno-destinara-bs-55-millones-a-la-escuelaantiimperialista-para-gestion-2017/ Recuperado en abril de 2017; "Gobierno: Escuela Antiimperialista permitirá a las FFAA interpretar el desarrollo geopolítico militar mundial". La Razón, 15 agosto 2016. Disponible en http://www.larazon.com/index.php? url=/nacional/Gobierno-Escuela-Antiimperialista-OTANEEUU 0_2546145402.html Recuperado en abril de 2017. 
una nueva doctrina en Bolivia, que reemplazaría la "tradicional guerra rígida y móvil, a la de una guerra popular de todo el pueblo", en palabras del Ministro de Defensa del país altiplánico.

Una iniciativa similar llevó a efecto el Gobierno de Nicolás Maduro en Venezuela, el 27 de agosto de 2017, cuando se realizó un ejercicio militar en respuesta a las amenazas del Presidente de Estados Unidos, Donald Trump, respecto de una eventual "opción militar" ante la grave crisis política y económica del país sudamericano. En la primera jornada de las maniobras participaron agrupaciones civiles, que recibieron lecciones de tiro, combate cuerpo a cuerpo y uso de baterías de cañones. En total, los ejercicios habrían contado con la participación de unos 200.000 militares y unos 700.000 reservistas, milicianos y civiles. ${ }^{42}$

Cabe apuntar que las débiles estructuras de integración del ALBA en el terreno estratégico no han representado un obstáculo para la cooperación entre sus miembros. Es decir, los países han optado hasta el momento por llevar sus relaciones en este ámbito por los canales bilaterales, donde destacan los sucesivos acuerdos militares entre Venezuela y Bolivia -donde destaca la creación en 2007 de la Fuerza Binacional de Ingeniería Social, integrada por militares de ambos países, con el objeto de contribuir en la construcción de infraestructura y en ayuda humanitaria en Bolivia (dejando de operar en abril de 2016 ante la grave situación económica venezolana), ${ }^{43}$ o los acuerdos militares bilaterales de Venezuela y otros miembros con países observadores del ALBA, como son Irán y Rusia, destacando últimamente los acuerdos entre La Paz y Moscú en materias consulares, militares y energía nuclear. ${ }^{44}$ No obstante, hasta el momento, los

${ }^{42}$ Véase "El régimen de Nicolás Maduro realizó maniobras de combate con la población civil”. Infobae, 27 agosto $2017 . \quad$ Disponible en http://www.infobae.com/america/venezuela/2017/08/27/el-regimen-de-nicolas-madurorealizo-maniobras-de-combate-con-la-poblacion-civil/ recuperado en agosto de 2017.

43 "Fuerza Binacional deja de operar después de 9 años". Cambio, 27 abril 2016. Disponible en http://www.cambio.bo/?q=node/5342 Recuperado en abril de 2016.

${ }^{44}$ Por ejemplo, véase "Rusia y Bolivia firman exención de visados y avanzan en cooperación”. Opinión, 13 de abril de 2016. Disponible en http://www.opinion.com.bo/opinion/articulos/2016/0413/noticias.php?id=187593 Recuperado en abril de 2016; "Choquehuanca viaja a Moscú en visita oficial”. Los Tiempos, 12 abril $2016 \quad$ Disponible en 
llamados de Venezuela por conformar un órgano de seguridad común antiimperialista no se han concretado, por lo que los avances en esta línea parecen todavía modestos.

Cabe señalar que los acuerdos entre Venezuela, Irán y Rusia han generado preocupaciones entre los países sudamericanos no miembros del ALBA, por una eventual carrera armamentista en la región. Para el primer país, tales acuerdos con actores extrarregionales representan una manera de incrementar el poderío militar ante la presencia estadounidense en Colombia. La alianza entre Venezuela e Irán ha despertado particularmente reacciones en diversos sectores de la región, al apreciarse que extrapola el conflicto de Medio Oriente a América del Sur. Venezuela identifica a Israel como enemigo, lo que ha desatado la respuesta de éste país mediante un reforzamiento de la cooperación militar con Colombia. De tal modo, se han planteado críticas al accionar venezolano, en tanto podría implicar una amenaza al objetivo de UNASUR y de otros mecanismos subregionales acerca de consolidar una Zona de Paz (Silva, 2011: 254), en tanto el "libreto bolivariano se opone a la mayor parte de las ideas en materia de democracia, desarrollo económico, defensa y política exterior que prevalecen en la región" (Russell, 2011: 130).

No obstante lo anterior, y que Estados Unidos sigue atentamente el desarrollo de estas relaciones del ALBA con países como Irán, Siria u otros países calificados desde el Departamento de Estado como Rogue States, es claro que tales aliados externos son pocos y con fuertes límites, donde ningún actor extrarregional pretende hostigar a la potencia norteamericana.

Refiriéndose a tales acercamientos extrarregionales, Günther Maihold destaca especialmente la situación de Irán que, con el impulso de Venezuela, ha logrado expandir su presencia en América Latina hacia países de distinto signo, como son Argentina, Bolivia, Brasil, Chile, Colombia, Cuba, Ecuador, México, Nicaragua y Uruguay. Particularmente notable resulta el caso de Bolivia, país con el cual los http://www.lostiempos.com/actualidad/nacional/20160412/choquehuanca-viaja-moscuvisita-oficial Recuperado en abril de 2016. "Bolivia anuncia que recibirá cooperación militar de Rusia". La Tercera, 7 septiembre 2016. Disponible en http://www.economiaynegocios.cl/noticias/noticias.asp?id=287372 Recuperado en septiembre de 2016. 
esfuerzos de la política iraní se han concentrado no sólo en materia de inversión en el sector de infraestructura de radiotelevisión y en la exploración de reservas de gas, sino también en la construcción de empresas de producción de lácteos. Junto con lo anterior, Maihold postula que "tanto Evo Morales como Ahmadineyad siempre han resaltado su interés por fomentar la cooperación en el marco de otros formatos de política global como el G-77 y el Movimiento de los Países No Alineados, para contrarrestar las acciones y agresiones externas" (2011: 197).

El mismo autor señala que Irán desea profundizar la cooperación Sur-Sur en muchos ámbitos de comercio e inversión en la región, donde destaca el ámbito de la energía nuclear, tópico para el cual existe la posición, ampliamente compartida por varios países latinoamericanos, de que no se debe vetar el acceso a esta tecnología en su uso en el plano civil. En este sentido, "Teherán aparece como un actor que podría, por un lado, ofrecer la tan deseada tecnología y, por el otro, recibir el uranio que naciones como Brasil y Venezuela pueden ofertar al mercado mundial" (Maihold, 2011: 199).

También es necesario resaltar el caso de Rusia, que ha dado cuenta de un notable interés por incrementar aún más su relacionamiento con los países del ALBA. En este plano, la relación desarrollada con Venezuela es fundamental, especialmente en el área de la cooperación militar y armamentística, ya que este país está recibiendo aproximadamente un $92 \%$ de sus armas convencionales desde el país eurasiático. Como señala Maihold:

"Cabe destacar aquí el interés del presidente venezolano Hugo Chávez por reintroducir al actor extrarregional Rusia en el espacio de América Latina como un hito alternativo a la reactivación de la IV Flota de Estados Unidos en el Caribe. Además, estos dos países han acordado cooperaciones en el marco del uso civil de la energía nuclear y la construcción de un banco de desarrollo común ruso-venezolano con un capital inicial de US\$6.000 millones" (Maihold, 2011: 201-202). 
Tales iniciativas de cooperación buscarían, en último término, ampliar la presencia de Rusia hacia América Latina en su conjunto, teniendo un lugar destacado también Bolivia y Nicaragua, aunque la potencia eurasiática ha sido cuidadosa de no adoptar un plano desafiante ni de enfrentamiento ante Estados Unidos.

También es relevante la cooperación que últimamente se aprecia entre Bolivia y China, en el plano militar. En julio de 2016 la potencia asiática donó a las fuerzas armadas del país andino 31 vehículos blindados, valorados en unos 8 millones de dólares, como parte de un programa de cooperación que Bolivia considera como el más importante que posee en materia militar. De hecho, el Presidente Evo Morales considera a China como un aliado geopolítico prioritario, que contribuye al desarrollo regional en desmedro de la presencia de Estados Unidos en la zona. ${ }^{45}$ La presencia de tales actores extrarregionales en América Latina, susceptibles de identificar como parte del mundo emergente, da cuenta de un cambio geopolítico global, marcado por la configuración de un contexto internacional con relevantes atributos de multipolarismo, que se manifiesta también en el terreno de la seguridad y defensa. Si bien tales potencias emergentes han sido cuidadosas de no presentarse en una postura hostil hacia Washington, lo cierto es que su actividad en la región sobrepasa con creces los objetivos puramente económicos y comerciales, pasando a involucrar los aspectos políticos y estratégicos, en su búsqueda por encontrar aliados en zonas tradicionalmente consideradas como periféricas. Ello, tomando en consideración una política exterior estadounidense que pone sus mayores esfuerzos internacionales en escenarios como Medio Oriente y la península de Corea.

En lo tocante al tono beligerante que ha exhibido en ocasiones el ALBA, principalmente de la mano de Venezuela, cabe señalar que éste ha generado cautelas en la región, como fue durante las tensiones de marzo de 2008 entre Ecuador y Colombia. A este respecto, el profesor estadounidense David Mares ha planteado que, de manera distinta a otras organizaciones regionales que promueven la paz y la cooperación mediante el consenso, el ALBA ha tomado una

\footnotetext{
${ }^{45}$ Véase "China y Bolivia buscan aumentar la cooperación militar bilateral”. Disponible en http://www.hispantv.com/noticias/bolivia/328608/ejercito-boliviano-aumentarcooperacion-militar-china Recuperado en octubre de 2017.
} 
posición ideológica, cuyo antiimperialismo ha tendido a desestabilizar a la región, como han sido sus fuertes roces con Colombia, en tanto un país aliado de Estados Unidos en América del Sur (Mares, 2012: 165), así como con otros gobiernos más cercanos a la democracia representativa y a la economía de libremercado.

De la mano de Venezuela, el ALBA ha seguido una orientación tendiente a la búsqueda de aliados, en un contexto regional apreciado bajo la lógica de amigo/enemigo, antes que a la generación de convergencias en el ámbito regional. La misma lógica disruptiva ha estado en la base de distintas declaraciones que ha efectuado el ALBA en apoyo a la demanda marítima de Bolivia, mediante las cuales la instancia regional se ha entrometido de lleno en un asunto de naturaleza bilateral entre Santiago y La Paz. Sobre la última declaración, de marzo de 2017, el Ministro de Relaciones Exteriores de Chile, Heraldo Muñoz, fue enfático en rechazar la señalada declaración, señalando que se trataba de "una declaración marginal de un organismo irrelevante". ${ }^{46}$

En línea con el argumento planteado por David Mares, Witker ha calificado el accionar venezolano como parte de un "multilateralismo beligerante", que mediante una lógica "adversarial" se ha constituido como una amenaza a la estabilidad, provocando enfrentamientos con aquellas visiones liberales de la democracia presentes en la región (Witker, 2012). Incluso, el académico estadounidense Douglas Farah ha extremado este argumento, planteando el concepto de los "Estados criminalizados", para referirse a los vínculos que tendrían ciertos países del ALBA con organizaciones criminales y terroristas (como es el caso de las ligaciones que existirían, por ejemplo, entre el gobierno de Venezuela y Hezbollah, entre otros), lo que estaría acarreando severas consecuencias para la seguridad y estabilidad regional (véase Farah, 2016).

\footnotetext{
${ }^{46}$ Véase al respecto "Países del ALBA entregan apoyo a Bolivia por aspiración marítima", disponible en http://www.latercera.com/noticia/paises-latinoamericanos-entregaron-apoyo-boliviala-demanda-maritima-chile/ Recuperado en octubre de 2017; y "Canciller Muñoz califica al ALBA como un organismo irrelevante tras respaldo a demanda marítima de Bolivia". Disponible en http://www.emol.com/noticias/Nacional/2017/03/08/848448/Canciller-Munoz-califica-al-ALBAcomo-un-organismo-irrelevante-tras-respaldo-a-demanda-martima-de-Bolivia.html Recuperado en octubre de 2017.
} 


\section{6.- El establecimiento y desarrollo del Consejo de Defensa Suramericano de la UNASUR}

Este capítulo analiza las tendencias que evidencia el Consejo de Defensa Suramericano, como consejo sectorial de la UNASUR encargado de los temas de defensa. En razón de lo anterior, se explica el origen y desarrollo del mismo, algunos de los temas más relevantes de su agenda -como son aquellos relacionados con la industria de la defensa, la ciberdefensa y los avances institucionales-, así como el rol cumplido, en tal sentido, por Brasil.

\section{a) La UNASUR y el Consejo de Defensa Suramericano}

Bajo el determinante impulso brasileño, la UNASUR surgió como un referente político de integración sudamericana, en respuesta a la necesidad de complementar los variados intentos de integración comercial y política que habían existido en la región desde la década de los sesenta, y que no habían alcanzado los resultados esperados.

En sus orígenes la UNASUR, que integra y vincula en su seno a países del MERCOSUR y la CAN, fue visualizada como una manera de avanzar en la colaboración para la creación de bienes públicos regionales, que contribuyeran a la gobernanza de la región en su conjunto. Tal organización busca promover una mayor integración cultural, social, económica y política, y atenuar las desigualdades, lograr una mayor inclusión social, fortalecer las democracias y reducir las asimetrías, en el marco del fortalecimiento de la soberanía e independencia de los Estados. Asimismo, como una instancia predominantemente política, en la práctica, la UNASUR ha desempeñado un rol de relevancia en la mediación de diversos conflictos internos e interestatales suscitados en la región (Planas, 2010). Como señalan Sanahuja y Verdes-Montenegro, como un mecanismo eminentemente político, en la práctica:

"UNASUR se ha configurado como un mecanismo relativamente ágil y efectivo de gestión de crisis y, en algunos casos, de prevención de conflictos, en parte como alternativa a la OEA. La 
Unión ha intervenido ya en varias ocasiones como las crisis boliviana de agosto de 2008; el golpe de Estado en Honduras de junio de 2009; la revuelta policial (intento de golpe de Estado, según el Gobierno) de septiembre de 2010 en Ecuador, y la controvertida destitución del Presidente Lugo en Paraguay en 2012" (Sanahujay Verdes-Montenegro, 2014: 500).

El origen de la UNASUR se remonta a las Cumbres de los Jefes de Estado y Gobierno de América del Sur que, con el fuerte apoyo de Brasil, se celebraron desde el año 2000. Tales reuniones dieron lugar posteriormente a la Comunidad Sudamericana de Naciones, establecida en diciembre del año 2004 en el Cuzco. La misma Comunidad dio origen a UNASUR, luego de la Cumbre de Isla Margarita, celebrada en abril de 2007.

Según señala el ex Subsecretario de Relaciones Exteriores de Chile, Ángel Flisfisch, la idea de la integración política era un asunto pendiente en la región hasta la creación de la UNASUR, surgida bajo la idea de que era necesario aprovechar lo ya avanzado, a través de la convergencia de los proyectos, procesos y organismos de integración ya vigentes en América del Sur. En esta línea, Flisfisch señala que la creación de dicha instancia:

"...obedeció a la conveniencia de contar con una instancia regional que permitiera promover y defender de manera más efectiva los intereses de los países de América del Sur en los foros y negociaciones internacionales...Los avances de la UNASUR son la expresión de la voluntad política de los países sudamericanos de acelerar el proceso de integración regional, sobre la base del respeto a la diversidad y la búsqueda de acuerdos políticos" (Flisfisch, 2010: 60-61).

El Tratado Constitutivo de la UNASUR se firmó el 23 de mayo de 2008, requiriendo para su entrada en vigor la ratificación de 9 de los 12 miembros. El 11 de marzo de 2011 se produjo un importante evento en el avance del proceso de 
institucionalización de UNASUR, por cuanto su Tratado Constitutivo entró en vigor para los nueve países que ratificaron y depositaron su instrumento de ratificación ante el Gobierno del Ecuador, depositario del acuerdo y sede del Secretariado. A mediados de diciembre de 2011 la Canciller colombiana, María Ángela Holguín, depositó en la capital ecuatoriana el instrumento por el cual su país -el único que estaba pendiente de esta formalidad- adhirió a UNASUR. EI Tratado constitutivo tiene el siguiente objetivo:

“...construir, de manera participativa y consensuada, un espacio de integración y unión en lo cultural, social, económico y político entre sus pueblos, otorgando prioridad al diálogo político, las políticas sociales, la educación, la energía, la infraestructura, el financiamiento y el medio ambiente, entre otros, con miras a eliminar la desigualdad socioeconómica, lograr la inclusión social y la participación ciudadana, fortalecer la democracia y reducir las asimetrías en el marco del fortalecimiento de la soberanía e independencia de los Estados". 47

Desde su arranque, la UNASUR, junto con contribuir a la gobernanza de América del Sur, se apreció como una manera de fortalecer el posicionamiento de la región en el concierto internacional, de acuerdo con los cambios acontecidos en el mundo, relacionados con la conformación de un sistema crecientemente multipolar, con un progresivo protagonismo de los países del mundo del Sur y donde prime el derecho internacional en la convivencia entre las naciones. En esta línea, el Tratado Constitutivo de la UNASUR señala en su preámbulo, entre otros elementos, lo siguiente:

"SEGURAS de que la integración es un paso decisivo hacia el fortalecimiento del multilateralismo y la vigencia del derecho en las

47 El Tratado Constitutivo de la UNASUR se encuentra disponible en http://www.comunidadandina.org/unasur/tratado_constitutivo.htm Revisado en agosto de 2015. 
relaciones internacionales para lograr un mundo multipolar, equilibrado y justo en el que prime la igualdad soberana de los Estados y una cultura de paz en un mundo libre de armas nucleares y de destrucción masiva...

RATIFICAN que tanto la integración como la unión suramericanas se fundan en los principios rectores de: irrestricto respeto a la soberanía, integridad e inviolabilidad territorial de los Estados; autodeterminación de los pueblos; solidaridad; cooperación; paz; democracia; participación ciudadana y pluralismo; derechos humanos universales, indivisibles e interdependientes; reducción de las asimetrías y armonía con la naturaleza para un desarrollo sostenible..."

En el marco de la UNASUR, en febrero de 2008 el Presidente Lula y el entonces Ministro de Defensa de Brasil, Nelson Jobim, propusieron la idea de crear un consejo sectorial encargado de canalizar la cooperación en defensa en el ámbito sudamericano, durante una visita de Estado a Argentina. En dicha ocasión, el Ministro Jobim sostuvo que el objetivo del nuevo organismo sería "el entendimiento con todos los países sudamericanos para que pudiesen tener la misma palabra sobre defensa en los organismos internacionales y resolver por medio de este Consejo las eventuales cuestiones sobre defensa que surjan" (en Moreira, 2008: 7).

Sin perjuicio de lo anterior, cabe destacar que la decisión de crear el Consejo de Defensa Suramericano (CDS) en el marco de la UNASUR contaba con ciertos antecedentes directos que conviene subrayar. Por ejemplo, considerando los avances realizados en el seno del MERCOSUR y la CAN, en materia de paz y seguridad, durante la primera Reunión de los Jefes de Estado y Gobierno de América del Sur, celebrada entre los días 31 de agosto y 1 de septiembre de 2000 en Brasilia, se acordó crear una Zona de Paz Sudamericana. En el Comunicado emanado de dicha cumbre se caracteriza a la región por su paz y ambiente de amistad y cooperación, expresando que "La superación definitiva de diferendos territoriales, según el ejemplo del acuerdo de 1998 entre Ecuador y Perú, 
constituye una demostración reciente del espíritu que prevalece en América del Sur, que ha hecho y hará de esta parte del mundo un área de paz y cooperación, sin conflictos territoriales".

En seguimiento de lo acordado en Brasilia, los Ministros de Relaciones Exteriores de los países de la CAN, el MERCOSUR y Chile, reunidos en La Paz en julio de 2001, formularon las bases para un proyecto sobre la Creación de una Zona de Paz y Cooperación Sudamericana.

Luego, durante la segunda Reunión de los Jefes de Estado Sudamericanos, celebrada en Guayaquil en julio de 2002, los Presidentes acordaron la Declaración sobre la Zona de Paz Sudamericana. El texto declara "A América del Sur como Zona de Paz y Cooperación, hecho histórico que refleja las mejores tradiciones de entendimiento y convivencia pacífica entre los pueblos de la región". El documento sigue planteando que "queda proscrito, en América del Sur, el uso o la amenaza del uso de la fuerza entre los Estados...queda proscrito, asimismo, el emplazamiento, desarrollo, fabricación, posesión, despliegue, experimentación y utilización de todo tipo de armas de destrucción en masa, incluyendo las nucleares, químicas, biológicas y tóxicas, así como su tránsito por los países de la región, de acuerdo con el Tratado de Tlatelolco y demás convenciones internacionales sobre la materia".

Los mencionados documentos, así como la posterior declaración de la UNASUR de la reunión extraordinaria de Jefes de Estado y de Gobierno, celebrada en San Carlos de Bariloche en agosto de 2008 -que proclamó nuevamente a Sudamérica como Zona de Paz-, serían antecedentes fundamentales para contextualizar la decisión de constituir el Consejo de Defensa Suramericano.

Como se aprecia, en un contexto internacional donde los temas tocantes a la seguridad y defensa eran cada vez más relevantes, se lanzaba la idea de establecer un consejo sectorial encargado de estas materias, cuestión que hasta ese momento era un asunto irresuelto en América del Sur. Abundando en lo anterior, Alfredo Forti señala que :

“...la conformación del Consejo de Defensa Suramericano, ideado como un esquema de seguridad cooperativo, nos permite 
establecer nuevos canales regionales de cooperación en el área de la defensa, que antes eran desarrollados en foros hemisféricos como las Conferencias de Ministros de Defensa de las Américas; y nos permite, de esa forma, avanzar en la articulación de una identidad suramericana en materia de defensa y en la instrumentación de soluciones regionales a los problemas regionales" (Forti, 2012: 290).

En coherencia con lo anterior, para Pablo Celi, la creación del Consejo de Defensa Suramericano respondería a una "reestructuración de las relaciones continentales", que pasan a desenvolverse en clave estratégica suramericana, "en la búsqueda de un modelo regional propio frente al difuso sistema interamericano, que se diluye como espacio inercial de vínculos privilegiados con los Estados Unidos" (Celi, 2012: 467).

La señera idea brasileña cobraría mayor fuerza, a raíz de la crisis diplomática protagonizada por Colombia y Ecuador en marzo de 2008, cuando tropas del primer país sobrepasaron las fronteras del territorio ecuatoriano, al momento de realizar la denominada Operación Fénix contra la guerrilla de las FARC. La situación de Colombia estaría también en el centro de los factores explicativos del desarrollo que se aprecia en el Consejo, por cuanto, como señalan Sanahuja y Verdes-Montenegro:

"El acuerdo entre Colombia y Estados Unidos de agosto de 2009 que permitiría el uso de bases militares estadounidenses en territorio colombiano fue la primera crisis que puso a prueba al CDS. Las amenazas colombianas de retirarse de UNASUR si se cuestionaba ese acuerdo en la región, y el papel jugado por el CDS como marco de diálogo y compromiso, podrían verse como prueba de los límites del regionalismo sudamericano y sus propósitos de autonomía regional ante la solidez de la alianza entre Washington y Bogotá, a quien otros gobiernos de la región tienden a ver como caballo de Troya de los intereses estratégicos 
de Estados Unidos en Sudamérica" (Sanahuja y VerdesMontenegro, 2014: 499).

Durante el año 2008, el Ministro Jobim iniciaría en Venezuela una gira por los países sudamericanos, con el objeto de exponer las características de la propuesta brasileña y concitar apoyo entre los países de la región. En marzo de 2012, el Ministro de Defensa brasileño, Celso Amorim, durante una conferencia magistral dictada en la Escuela Militar de Chile, señaló al respecto que:

"Derivada de la voluntad soberana de sus miembros, UNASUR afianzó la identidad política sudamericana. Esa maduración de la conciencia que América del Sur pasó a tener de sí misma permitió a nuestros Estados ampliar e institucionalizar las acciones en el área de defensa. Con la creación del Consejo de Defensa Suramericano (CDS), la integración alcanzó una nueva etapa: además de actividades como la economía y el comercio, América del Sur dispuso de mejores instrumentos para asegurar la continuidad de la paz y de la seguridad" (Amorim, 2012: 503).

Aunque la propuesta de creación del Consejo fue impulsada fuertemente por la mediación brasileña ante una crisis bilateral, no es menos dependiente de otros factores de largo plazo, como son la definición de doctrinas de seguridad y defensa de matriz democrática y el establecimiento de regímenes de medidas de confianza mutua en el Cono Sur, a lo que se puede añadir la adopción de la Declaración de Bogotá de julio de 2006, suscrita en la I Conferencia de Ministros de Defensa de la Comunidad Sudamericana de Naciones, que planteó la necesidad de "promover en la región mecanismos que, basados en los principios de soberanía y no intervención, faciliten la cooperación para luchar de manera más efectiva contra las amenazas a la defensa y seguridad de América del Sur conforme al ordenamiento jurídico de cada país". Asimismo, el Consejo es igualmente expresión del liderazgo regional y global al que aspira Brasil que, en el ámbito regional, revela su preocupación por la inestabilidad de la región andina, 
así como por el control efectivo de su porosa frontera amazónica (Sanahuja y Verdes-Montenegro, 2014: 498).

Sobre la base de lo antes reseñado, la decisión para establecer el Consejo se adoptaría en diciembre de 2008, durante la Reunión Extraordinaria de Jefas y Jefes de Estado y de Gobierno de la UNASUR, celebrada en Salvador de Bahía. ${ }^{48}$ Al presente, el organismo se constituye como una instancia de consulta, cooperación y coordinación en materias de defensa. Además de consolidar a la región como una Zona de Paz, el Consejo tiene el objetivo de contribuir al fortalecimiento de la unidad regional, generando consensos para fortalecer la cooperación en defensa. En palabras del ex Ministro de Defensa de Chile, Francisco Vidal:

"La cooperación...es el mejor camino para generar una voz propia, que se escuche y atienda en el mundo, y que nos permita aprovechar las oportunidades de la diplomacia multilateral...Así contamos ahora con un órgano permanente de diálogo, coordinación y consulta, integrado por todos los Ministros y Ministras de Defensa de cada uno de los miembros de UNASUR...Creemos firmemente que hemos dado un paso fundamental para proyectar a futuro la paz y estabilidad en nuestra región, para seguir construyendo el desarrollo de nuestros pueblos" (En Ministerio de Defensa Nacional de Chile, 2009:1517).

En su arranque, el CDS fue promovido por Brasil como una instancia flexible de consulta y cooperación, antes que como un denso mecanismo institucional de

${ }^{48}$ Aparte del Consejo de Defensa Suramericano, y para complementar este sucinto panorama sobre los avances en el terreno de la seguridad y defensa en el marco de UNASUR, pero esta vez en los temas relativos a la seguridad pública, cabe señalar la creación del Consejo Suramericano en materia de Seguridad Ciudadana, Justicia y Coordinación de Acciones contra la Delincuencia Organizada Transnacional, en noviembre de 2012 en la ciudad de Lima. Un breve balance de su primera reunión puede verse en http://www.derf.com.ar/despachos.asp?cod_des=562546 Recuperado en agosto de 2013. 
seguridad colectiva, representando una manera de repensar el sistema interamericano de seguridad y defensa, tan fuertemente impugnado por varios países de la región. Según Verónica Gómez, "Este consejo no apunta a ser una alianza militar clásica. EI CDS no busca conformar unas Fuerzas Armadas suramericanas; no pretende conformar una capacidad operativa conjunta, ni un mando conjunto, y ni siquiera una política común de defensa" (Gómez, 2012: 370). La baja densidad de la institucionalidad en el terreno defensivo, susceptible, al mismo tiempo, de ser interpretada como alta flexibilidad, se explica, en parte, por la voluntad política de los Estados de mantener cotos de soberanía reservados a los ámbitos nacionales, así como por la heterogeneidad que se aprecia entre los miembros plenos y asociados del bloque en torno a sus concepciones acerca de la seguridad y la defensa, lo que consecuentemente afecta las percepciones de los países sobre el empleo de las fuerzas armadas.

Atendida la situación anterior, el principal mérito del Consejo, a juicio de Marco Aurelio García, ha sido el de lograr reunir a todos los países de América del Sur, incluso aquellos que enfrentaban una situación más compleja, como es el caso de Colombia, no solo por su contencioso con Ecuador y con Venezuela, sino también por la persistencia de focos de insurgencia interna y por la presencia de bases estadounidenses (García, 2011: 168). En conjunción con lo anterior, como señalaba Pablo Celi en una entrevista:

"La misión del Consejo de Defensa no es la predeterminación de enemigos, la predeterminación de conflictos, las hipótesis de guerra, las hipótesis de agresión; no es partir de esta hipótesis negativa sino partir de un acompañamiento positivo a los procesos de integración regional...Esto es lo que ha permitido que el Consejo de Defensa sea un espacio de diálogo, de intercomunicación de políticas de defensa nacionales. No existe hoy una política de defensa regional: existen políticas de defensa nacionales y un espacio de cooperación entre ellas" (En Calle, 2014: 230). 
El impulso del Consejo por parte de Brasil debe entenderse en el marco de la prioridad sudamericana asumida por la administración Lula, uniéndose al liderazgo asumido por este país en la Misión de Estabilización de Naciones Unidas en Haití (MINUSTAH), y como parte de una estrecha vinculación entre su política exterior y de defensa. En 2008, el Presidente brasileño sostenía que "O Brasil quer asociar e seu futuro ao destino da América do Sul. Nehum de nossos países pode, sozinho, aspirar a prosperidade. Mais do que generosos, temos que ser solidários" (en Rizzo de Oliveira, 2009:80).

En último término, el Consejo de Defensa busca fortalecer una identidad sudamericana en el ámbito de la defensa, constituyéndose como una instancia expresiva del desarrollo de una comunidad de seguridad a nivel regional. Como se indicó más arriba, esta comunidad, de carácter pluralista en los términos planteados por Karl Deutsch, tiene su origen en los avances estratégicos que se registraron principalmente en el Cono Sur, con el desarrollo del MERCOSUR. Si esta última instancia tuvo como líderes de la integración a Argentina y Brasil, lo cierto es que a nivel sudamericano sólo éste último aparece en un papel prominente. Es decir, teniendo como base la apreciación geopolítica de Brasil respecto de la región, pensada en términos de América del Sur antes que como América Latina (lo que consecuentemente excluye a México del proceso), el liderazgo brasileño -aunque todavía poco constante- aparece como el responsable principal de la proyección sudamericana de la comunidad de seguridad surgida originalmente en el Cono Sur.

En los hechos, el Consejo ha servido como un valioso mecanismo de diálogo y cooperación, que ha generado confianza entre los miembros y previsibilidad en las conductas, disminuyendo de esta manera la incertidumbre y reforzando la estabilidad en la región. El nivel de confianza y cooperación alcanzado forma parte del desarrollo de una concepción cooperativa y multilateral en el plano de la seguridad regional, con políticas de defensa cada vez más concurrentes, entendiendo los países que su seguridad depende en gran medida del entorno. En este orden de ideas, Pablo Celi plantea que: 
"En el nuevo regionalismo sudamericano, la integración en seguridad y defensa, tanto en sus aspectos políticos como en su desarrollo funcional y estructural, coadyuva a la construcción de la arquitectura sistémica de una seguridad regional de índole cooperativa, a la cual favorecen la transparencia y la legitimidad democrática de las políticas e instituciones nacionales de defensa, como paradigmas de confianza mutua y responsabilidad internacional de los Estados suramericanos" (Celi, 2012: 473).

En suma, el Consejo ha contribuido al desarrollo de una comunidad pluralista de seguridad a nivel sudamericano, representando un claro ejemplo de la relación positiva que existe entre integración regional y seguridad. De esta manera, dicho órgano regional se ha constituido como un instrumento de inserción global de los países miembros que busca, en último término, incrementar la autonomía de la región. Pero no es una autonomía de carácter cerrado y defensivo ante los sucesos internacionales, en la línea del regionalismo de mediados del siglo XX con sus postulados sobre el desarrollo endógeno -impulsados en su momento por la CEPAL-, sino una autonomía que se asume proactivamente y de manera responsable respecto de los procesos globales.

Tokatlián y Russell han denominado a este tipo de autonomía como "autonomía relacional". Según tales autores, ella requiere de una participación activa y comprometida en la elaboración de las normas de la gobernanza global. Por lo tanto, ella no supone la autosuficiencia o el aislamiento de los procesos globales sino, más bien, se relaciona con el "poder para participar e influir eficazmente en los asuntos mundiales, sobre todo en organizaciones y regímenes internacionales de todo tipo" (Tokatlián y Russell, 2003: 179).

Bajo este enfoque, es posible sostener que el Consejo de Defensa Suramericano forma parte de un proceso multidimensional de integración, que busca consolidar a la región como una Zona de Paz, sin hegemonías, y bajo la idea central de alcanzar la autonomía estratégica de América del Sur y su inserción en el contexto multipolar global. En el mismo tenor, según se señala en un documento preparado 
por el Ministerio de Defensa Nacional de Ecuador, tal Consejo, como esfuerzo integracionista,

“...manifiesta e impulsa un proceso de creciente confianza entre los Estados, de relaciones colaborativas y de búsqueda de respuestas a problemas comunes, como el necesario replanteamiento de la región, de sus condiciones internas actuales y de sus potencialidades de inserción en el sistema mundo contemporáneo" (Ministerio de Defensa Nacional del Ecuador, 2014: 179).

Resulta relevante destacar que la interacción gubernamental en el foro que representa el Consejo de Defensa, ha implicado un proceso de socialización y aprendizaje de los funcionarios civiles y militares, provenientes del sector de la defensa y del mundo diplomático, que participan de las reuniones de dicho órgano y de las actividades que forman parte de los planes de acción. Ello ha tenido como efecto la construcción conjunta de una agenda regional en el plano de la defensa que, pese a las divergencias existentes, ha contribuido a la difusión de ideas, conceptos y prácticas colectivas en el plano de la defensa, lo que ha generado un ambiente estable, de confianza y altamente propicio para la regionalización de la cooperación.

Bajo un punto de vista institucionalista, es posible señalar, de manera análoga a lo recién explicado, que Brasil impulsó la creación del Consejo como parte de su agenda regional y global, sin perjuicio que el organismo ha resultado, en la práctica, como un instrumento eficaz para canalizar la cooperación en el sector de la defensa en América del Sur, distribuyendo información entre los miembros y disminuyendo, en consecuencia, la incertidumbre y las posibilidades de conflictos. Según Merke, "Estas ideas explican en parte por qué la propuesta brasileña gozó de amplia aceptación y como diversos Estados vieron en el CDS la posibilidad de controlar o restringir las movidas unilaterales de sus miembros mayores" (Merke, 2012: 129). 
Haciendo una breve cronología del establecimiento del Consejo, cabe señalar que el Presidente Lula formalizó, con ocasión de la Cumbre Extraordinaria de Jefas y Jefes de Estado y de Gobierno de la UNASUR, realizada en mayo de 2008 en Brasilia, su propuesta de creación de dicho organismo. No obstante, éste no fue creado inmediatamente, por cuanto a sugerencia de la entonces Presidenta de Chile, Michelle Bachelet -en ese momento este país ejercía la Presidencia Pro Témpore de la UNASUR-, se concordó la creación de un Grupo de Trabajo, con el objeto de analizar y profundizar la idea, elaborando un proyecto de Estatuto.

Según señala un documento del Ministerio de Defensa Nacional de Chile, durante el año 2008 el mencionado grupo se reunió en cuatro ocasiones en Santiago. En el último encuentro, celebrado en diciembre de ese año, se presentó un texto que contenía los principios, los objetivos generales y específicos y la estructura de funcionamiento del futuro Consejo. En líneas generales, el texto ratificado se refiere a tres grandes directrices, que buscan fundamentar la actuación de los componentes del CDS (Ministerio de Defensa Nacional de Chile, 2009: 21-22):

- Consolidar América del Sur como una zona de paz, base para la estabilidad democrática y el desarrollo integral de nuestros pueblos, y como aporte a la paz mundial;

- Construir una identidad suramericana en materia de defensa, que tome en cuenta las características subregionales y nacionales y que contribuya al fortalecimiento de la unidad de América Latina y del Caribe, y;

- Generar consensos para fortalecer la cooperación en materia de defensa.

Sobre la base de lo anterior, y de acuerdo a lo señalado en la primera reunión del CDS, celebrada en marzo de 2009 en Santiago de Chile, el Consejo también propiciaría la definición de enfoques conceptuales, la identificación de factores de riesgo y amenazas que puedan afectar la paz regional y mundial, y la atenuación de las asimetrías en el ámbito de la defensa. En último término, con el CDS se buscaba crear un mecanismo para contribuir a la articulación de posiciones conjuntas entre los países de la región ante foros multilaterales sobre defensa. 
Todo ello, a partir de criterios de gradualidad y flexibilidad (Sanahuja y VerdesMontenegro, 2014: 507).

Sin perjuicio de lo anterior, cabe subrayar que la idea de establecer un mecanismo permanente de reuniones entre los Ministros de Defensa de América del Sur, había tenido episodios anteriores al establecimiento del CDS. El antecedente inmediato fue la Conferencia de Ministros de Defensa de la Comunidad Sudamericana de Naciones, celebrada en Bogotá en junio del 2006, además de los ya mencionados aportes de otros mecanismos subregionales, como son las iniciativas en materia de seguridad y defensa impulsadas en el marco del MERCOSUR y la CAN. Aunque ha sido el mencionado bloque del Cono Sur el que otorgó un más fuerte apoyo, en su papel de núcleo duro de la integración sudamericana, a la relación entre integración y seguridad en la región. Es decir, los primeros aportes para la constitución de una comunidad de seguridad a nivel sudamericano se dieron en el plano subregional, desde el Cono Sur, área desde la cual los avances tendieron a derramarse al ámbito regional.

A ello cabría agregar la cooperación en defensa que de facto se ha dado en la región, a nivel bilateral y multilateral, donde destaca el intercambio entre las respectivas fuerzas armadas; la realización de ejercicios militares conjuntos; la participación en operaciones de paz bajo mandato de Naciones Unidas, particularmente en la MINUSTAH; así como las medidas de fomento de la confianza, que forman parte fundamental de la agenda interamericana, desde la celebración en Santiago el año 1995, de la primera Conferencia de Fomento de las Medidas de Confianza Mutua y Seguridad.

Entre los principios que guían al CDS, destacan el respeto por la soberanía y la autodeterminación, la integridad territorial de los Estados y la no intervención en asuntos internos. Resaltan al mismo tiempo, el respeto por las instituciones democráticas, el respeto irrestricto por los derechos humanos y el ejercicio de la no discriminación en el ámbito de defensa, con el fin de reforzar y garantizar el Estado de Derecho (Ministerio de Defensa Nacional de Chile, 2009:85).

Cabe señalar que, en lo tocante a las posiciones adoptadas por los países de la región frente al Consejo, a nivel general puede sostenerse que ha concitado consenso, manifestando los Estados en distintas ocasiones su apoyo y respaldo. 
Si bien Colombia expresó sus aprehensiones en un principio, terminó pronto adhiriendo a la iniciativa brasileña. Lo mismo ocurrió con Argentina, que antes que UNASUR tenía puesto su interés por avanzar en temas de defensa en el contexto del MERCOSUR, donde con anterioridad existían relevantes mecanismos de cooperación militar a nivel subregional y bilateral.

Venezuela también ha apoyado el Consejo, sobre todo considerando la perspectiva de que este deja afuera a Estados Unidos en los asuntos de defensa de la región. Una posición similar ha tenido en líneas generales Bolivia y Ecuador, entre otros. Chile fue entusiasta desde un principio con la idea de establecer el Consejo. Estos relevantes apoyos han servido como un acervo poderoso para la consolidación del Consejo y para la operacionalización de sus actividades en la región, promoviendo que este novedoso órgano contribuya efectivamente a la paz y estabilidad sudamericana y, de este modo, a la gobernanza internacional en su conjunto.

Respecto de su funcionamiento, el Consejo está integrado por los Ministros de Defensa, o sus equivalentes, de los países miembros de la UNASUR, cuyas iniciativas y decisiones son sometidas a los Jefes de Estado y de Gobierno. La Presidencia del organismo, que tiene la responsabilidad de coordinar las actividades en desarrollo, se le asigna al Ministro de Defensa del país que ocupe la Presidencia Pro Témpore de la UNASUR. Existe igualmente una instancia ejecutiva, conformada por los Viceministros de Defensa o sus equivalentes, que se reúne cada semestre para supervisar el cumplimiento de las decisiones ministeriales.

Asimismo, los trabajos del CDS se organizan en torno a los Planes de Acción anuales, los que a su vez se estructuran alrededor de ejes temáticos. Durante la Primera Reunión de Ministras y Ministros de Defensa del Consejo de Defensa Suramericano, celebrada en Santiago de Chile en marzo de 2009, se aprobó el primer Plan de Acción, donde se establecieron los siguientes ejes, que se mantienen hasta hoy: Política de Defensa; Cooperación Militar, Acciones Humanitarias y Operaciones de Paz; Industria y Tecnología de la Defensa y; Formación y Capacitación. 
El siguiente cuadro analiza la evolución en el tiempo de las actividades del Consejo, según los señalados ejes que contemplan los planes de acción:

\section{Evolución del número de actividades del Consejo de Defensa Suramericano por ejes de cooperación (2009-2013)}

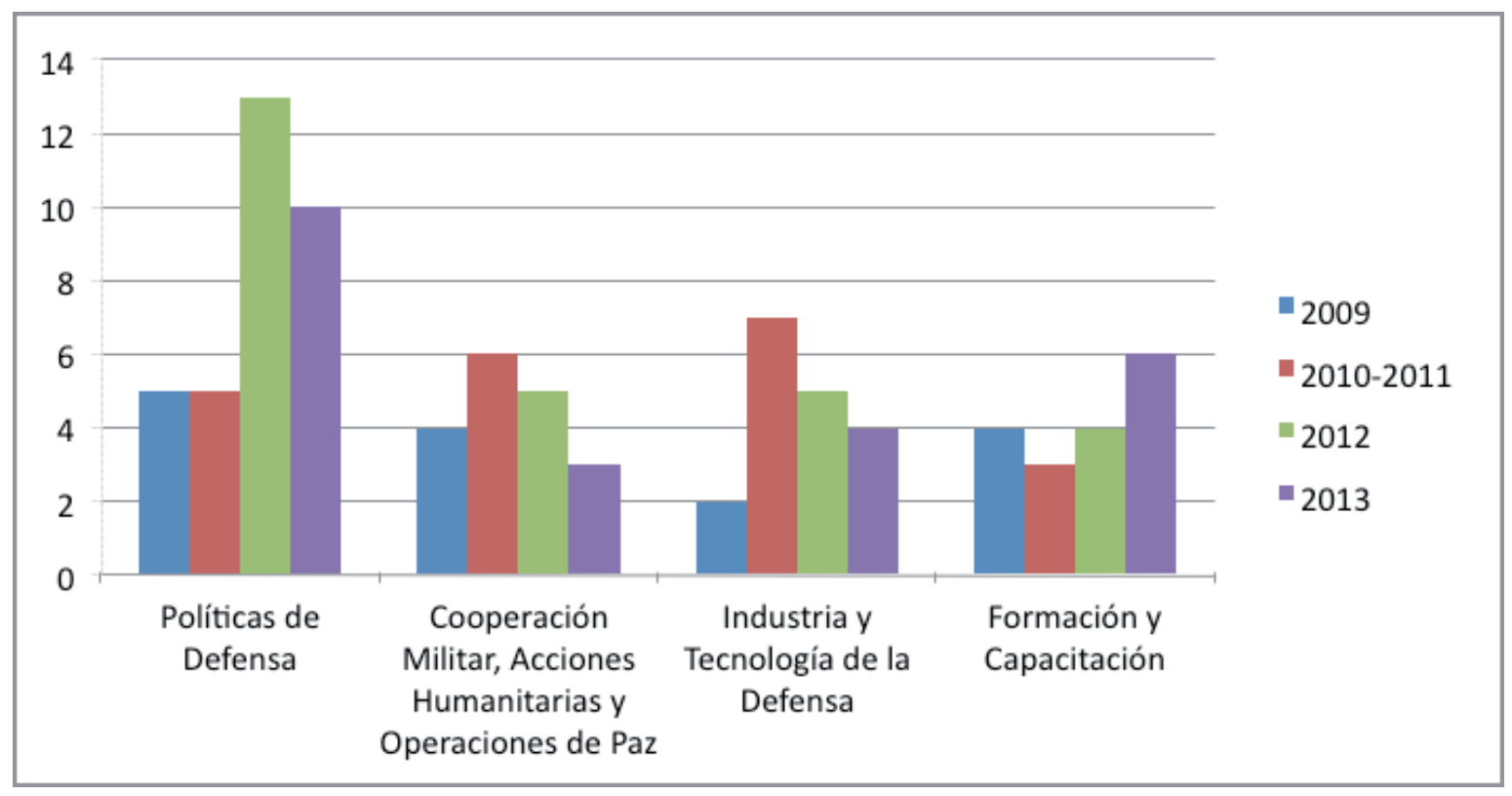

Fuente: Sanahuja y Verdes-Montenegro (2014: 508).

Como es posible apreciar, entre los años analizados, el eje Políticas de Defensa ha contado con un mayor desarrollo, sin perjuicio que el ámbito Formación y Capacitación ha ido ganando fuerza últimamente. En este ámbito, cabe destacar la reciente creación de la Escuela Suramericana de Defensa (ESUDE), en QuitoEcuador, sobre la cual volveremos más adelante.

En lo tocante a la implicación de los Estados miembros en los planes de acción, como señalan Sanahuja y Verdes-Montenegro, ello está relacionado con la escala y proyección internacional de cada uno de ellos, con un papel secundario para Bolivia, Guyana, Paraguay, Surinam y Uruguay. Estos cinco países suponen algo más el $15 \%$ de las actividades, que es lo que representan por sí solos los miembros más activos, que son Argentina o Perú. Del mismo modo, del grupo de seis países que han asumido la puesta en marcha de un número significativo de actividades en este órgano (Argentina, Brasil, Chile, Ecuador, Perú y Venezuela), 
el reparto de responsabilidades es mucho más equilibrado. También, cabe destacar que Colombia es el país que, significativamente, muestra un grado de implicación menor que el que correspondería a su peso en la región (Sanahuja y Verdes-Montenegro, 2014: 508-509).

\section{b) Temas relevantes en la agenda del Consejo de Defensa Suramericano}

La agenda del Consejo de Defensa Suramericano se ha concentrado en temas como la utilización de las fuerzas armadas en misiones externas y frente a situaciones de desastres; el aumento de la transparencia y la confianza entre los países miembros, en relación con las capacidades militares -a este respecto destaca la definición de una metodología para la medición de los gastos en

defensa, aprobada por los Ministros de Defensa en noviembre de 2012, y la creación de un registro de inventarios militares, aprobado en febrero de 2014-; el intercambio de experiencias en la participación en operaciones de paz, en materia de modernización de los Ministerios de Defensa y en lo referente a la promoción de enfoque de género; así como el fortalecimiento de la industria de la defensa, sin olvidar los aspectos relativos a la generación de estudios y capacitación en asuntos de defensa.

En el plano de las medidas de la confianza, que desde los orígenes del CDS han formado parte importante de la agenda regional, cabe señalar que el órgano ha dado continuidad a la tradición de seguridad cooperativa, que se puso en marcha en América Latina ya desde la década de los noventa, que recibiría un impulso relevante desde el plano hemisférico.

En esta materia, particularmente relevante fueron los resultados emanados de la reunión de Bariloche, de agosto de 2009, convocada a partir de la crisis generada por la posibilidad de alcanzar un acuerdo entre Estados Unidos y Colombia para la instalación de bases militares en éste último país, así como la Resolución adoptada durante la Reunión Extraordinaria de Ministros de Relaciones Exteriores y de Defensa de la UNASUR, celebrada en Quito, Ecuador, el 27 de noviembre de 2009, que establece un mecanismo de Medidas de Fomento de la Confianza y 
Seguridad. Esta declaración, en el punto I, numeral II (sobre Actividades Militares Intra y Extra regionales), señala que los Estados deben:

- Notificar con antelación, a los respectivos Países Miembros limítrofes y a la UNASUR, cualquier maniobra, despliegue o ejercicio militar, terrestre, aéreo o naval planificado y oportunamente, tan pronto como sea posible, los no planificados que se realicen en las zonas fronterizas en cuanto a número de efectivos, ubicación respecto a las fronteras, naturaleza y cantidad de equipo que se utilizará. A solicitud de la parte notificante, las partes notificadas respetarán la estricta confidencialidad de la información.

- Notificar a UNASUR el desarrollo de ejercicios militares sea con países regionales o extrarregionales.

- Invitar a observadores militares de países de la UNASUR a los ejercicios internacionales anteriormente mencionados.

- Establecer mecanismos de comunicación entre fuerzas militares de frontera, a fin de coordinar e informar sus actividades.

También es relevante la Declaración de Guayaquil, adoptada durante la II Reunión Ordinaria del CDS, de mayo de 2010, en la cual los Ministros de Defensa acuerdan, entre otros, "Aprobar el conjunto de procedimientos de aplicación para las Medidas de Fomento de la Confianza y Seguridad, desarrollados en las reuniones de la Instancia Ejecutiva que tuvieron lugar en Manta, los días 28 y 29 de enero de 2010, en Guayaquil, el 5 de mayo, y en la Reunión de Trabajo celebrada en Quito, el 8 y 9 de abril de 2010, de conformidad con el mandato de la Resolución de los Ministros de Relaciones Exteriores y de Defensa de la UNASUR, de 27 de noviembre de 2009". Posteriormente se aprobaría el Mecanismo de Seguimiento de los procedimientos de aplicación de las Medidas de Fomento de la Confianza y Seguridad, en el marco de la V Reunión Ordinaria del Consejo de Defensa Suramericano, celebrada en Paramaribo, Surinam, el 20 de febrero de 2014.

Además, junto con el establecimiento de una metodología de medición del gasto militar y la creación de un registro de inventarios militares, se ha incluido un 
Formulario Suramericano de Inventarios Militares (FOSIM), a fin de hacer más transparente el inventario militar de cada Estado miembro.

Todos los elementos mencionados anteriormente "nos permiten incrementar la transparencia, el conocimiento mutuo y la identificación de las capacidades de la región, sin dudas constituyen un gran avance en la construcción de la confianza y la cooperación regional y en la generación de estrategias y políticas comunes en el área de la defensa" (Forti, 2012: 292). Respecto de lo antes señalado, Verónica Gómez comenta lo siguiente:

"Del conjunto de medidas de confianza vale destacar: la apertura para compartir la información sobre los gastos militares y las estrategias de defensa, no con la pretensión de homologar las inversiones de defensa, dadas las enormes diferencias existentes entre nuestros países, pero sí ajustarlas al margen de cualquier tentación por una carrera armamentista. Un segundo elemento, la franqueza para mantener una información abierta sobre maniobras y operaciones conjuntas con países por fuera de la región, algo que parece evidente pero que no lo es tanto en una región caracterizada por una secular dependencia militar con respecto a Estados Unidos y su geopolítica" (Gómez, 2012: 371).

También cabe destacar, en el marco del segundo eje de acción del CDS, relativo a la cooperación militar en materia de acción humanitaria y operaciones de paz, la elaboración de un mapa de riesgo de desastres en cada país de la región, la exploración mecanismos de respuesta a los desastres, incluyendo un inventario de capacidades y la elaboración de un protocolo de empleo coordinado de las fuerzas militares en apoyo ante situaciones de catástrofes; así como los ejercicios combinados a escala regional sobre operaciones de paz y ayuda humanitaria, denominados "UNASUR", que corresponden a simulaciones, aunque no contemplan hasta ahora despliegues en el terreno (Sanahuja y VerdesMontenegro, 2014: 513). Chile y Perú han tenido un papel protagónico en esta temática, estando actualmente los países trabajando en la elaboración de un 
protocolo de empleo coordinado de las fuerzas militares en apoyo humanitario ante desastres y catástrofes.

Entre todos los avances explicitados anteriormente, en este acápite se desarrollan de manera más específica ciertos temas que han cobrado últimamente una mayor visibilidad política en los trabajos del CDS, como es el caso de la industria de la defensa, la ciberdefensa, y la creación del Centro de Estudios Estratégicos de Defensa (CEED) y la Escuela Superior de Defensa (ESUDE), como parte de un esfuerzo regional por generar un pensamiento estratégico propiamente sudamericano. Tales materias tienen una alta trascendencia en términos de avanzar hacia la autonomía estratégica regional, en un contexto global marcado por un creciente multipolarismo.

\section{La industria de la Defensa}

Bajo el prisma de la autonomía estratégica de la región, las labores del Consejo de Defensa Suramericano en el ámbito de la industria de la defensa resultan particularmente importantes, por cuanto, como señalan Saint-Pierre y Zague, dicha industria "permite reducir la dependencia externa en la adquisición y gozar de cierta autonomía en el diseño estratégico de la defensa" (Saint-Pierre y Zague, 2014: 182). En el fondo, "Se trataría de reducir la dependencia de los tradicionales proveedores de Europa y de Estados Unidos mediante una industria regional viable, para lo que se requiere de la escala y la tecnología que sólo puede asegurar la cooperación regional" (Sanahuja y Verdes-Montenegro, 2014: 516).

En este ámbito, los principales proyectos que se llevan a cabo en el CDS se refieren a la construcción de aviones de entrenamiento (el denominado UNASUR I) y no tripulados, en los cuales destaca el activo papel que cumplen Brasil y Argentina, siendo el primer país, desde luego, el que posee mayores capacidades y una visión estratégica en el tema y, por lo tanto, el más interesado en el desarrollo de esta dimensión en el seno del Consejo.

Otra iniciativa es la participación de empresas de Chile y Argentina en el proyecto del futuro avión de transporte militar Embraer C-390 y los compromisos de compra de varias unidades de esos dos países, así como de Colombia. Aunque en ciertos 
casos se trata de proyectos que son anteriores a la creación del Consejo, habría que mencionar igualmente la cooperación bilateral entre Argentina y Brasil, que ha tenido como resultado los vehículos militares "Gaucho" y "Guaraní", así como la modernización de misiles argentinos con tecnología brasileña (Sanahuja y VerdesMontenegro, 2014: 515).

Según señalan Sanahuja y Verdes-Montenegro, el ámbito de la industria de la defensa corresponde al eje más afectado por las profundas asimetrías que se observan en las capacidades de los miembros de la UNASUR. En el contexto de los planes de acción sobre esta materia en el Consejo, Bolivia, Paraguay y Surinam no asumen ningún compromiso en este ámbito, mientras Guayana o Uruguay sólo han sido corresponsables en una tarea. Por el contrario, Argentina, Brasil, y Venezuela son mucho más activos (Sanahuja y Verdes-Montenegro, 2014: 516).

Respecto del desarrollo de la industria brasileña en defensa, destaca la cooperación que se ha planteado entre Brasil y Suecia, plasmada en la nueva generación de la línea de producción del Gripen. Este avión será la primera acción sustantiva entre ambos países, luego de establecerse una asociación estratégica, que incluye un contrato entre SAAB y el Gobierno Federal de Brasil, para la producción de 36 aviones Gripen. Para Brasil ese contrato tiene un carácter de cooperación activa en el plano industrial, transferencia tecnológica, desarrollo conjunto de productos (incluso con el interés de ampliar la cooperación a otras áreas de la aviación civil).

Siendo Brasil el país que más desarrollada tiene su industria de la defensa -pese a lo cual sigue siendo un comprador en este mercado internacional-, sería esperable que el trabajo colectivo en el marco del Consejo de Defensa contribuya al desarrollo de esta industria en la región. Es decir, que la industria brasileña arrastre consigo a otros países de la región, como Argentina y Chile, contribuyendo de este modo a la autonomía regional sudamericana. El ex Ministro de Defensa de Brasil, Nelson Jobim, ha señalado a este respecto lo siguiente:

"Complementariamente, los esfuerzos para promover la integración y el fortalecimiento de la industria de defensa regional 
pretenden abastecer, oportunamente, en todas las situaciones, productos estratégicos de defensa de calidad y costo aceptable para las Fuerzas Armadas suramericanas, reduciendo así la dependencia de fuentes de suministro extra regionales (En Ministerio de Defensa Nacional de Chile, 2009: 25).

La ingente actividad de Brasil en la materia en el seno del Consejo, tiene su base en la Estrategia Nacional de Defensa, publicada el año 2008, según la cual la seguridad de la región es fundamental para la defensa de este país y para la integración de las bases industriales de defensa. Bajo este enfoque, el establecimiento del Consejo favorecería la conformación de un mercado regional para la industria defensiva del gigante sudamericano, como parte de su estrategia de desarrollo, y en estrecha vinculación con la política exterior, articulada de manera magistral desde Itamaraty.

Lo antes señalado ha llevado a Rita Giacalone a señalar que los países de la UNASUR tendrían para la industria de defensa de Brasil un rol dual: como socios en el desarrollo de proyectos conjuntos y como potenciales clientes para sus productos y tecnologías (Giacalone, 2014: 166). Lo relevante es que este impulso de Brasil, respondiendo firmemente a sus intereses nacionales, sirva al mismo tiempo a los intereses de la región en su conjunto. Ello eventualmente demostrará la capacidad de este país de configurarse como un líder regional, cambiando ciertas interpretaciones que aún lo aprecian más como un potencial hegemón, antes que como un partner, en el camino de la integración y de la inserción internacional de América del Sur.

\section{La Ciberdefensa}

Un tema que ha logrado últimamente una especial relevancia en la agenda del Consejo es la ciberdefensa. A este respecto, cabe señalar que el Plan de Acción del año 2012 contempló, en el eje sobre políticas de defensa, la "conformación de un Grupo de Trabajo para evaluar la factibilidad de establecer políticas y mecanismos regionales para hacer frente a las amenazas cibernéticas $o$ 
informáticas en el ámbito de la defensa". A su vez, el año 2013 el Plan de Acción siguió en la misma línea. Pero como señala Candela Justribó (2014), es a partir de la VII Reunion Ordinaria del Consejo de Jefas y Jefes de Estado y de Gobierno de la Unión de Naciones Suramericanas, celebrada el 30 de agosto de 2013 en Paramaribo, Suriname, que el tema cobró una mayor relevancia en la agenda regional, luego del público conocimiento de actividades de ciberespionaje sobre el Gobierno de Brasil, por parte de Estados Unidos.

Sobre la base de las mencionadas actividades contempladas en los previos planes de acción del Consejo, así como de las actividades de ciberespionaje por parte de Estados Unidos, la Declaración de la reunión de Paramaribo de la UNASUR:

29. Instruye al Consejo de Defensa Suramericano (CDS) y al COSIPLAN, evaluar la cooperación con otros consejos ministeriales competentes y avanzar en sus respectivos proyectos sobre defensa cibernética y la interconexión de las redes de fibra óptica de nuestros países, con el objetivo de tornar nuestras telecomunicaciones más seguras, fortalecer el desarrollo de tecnologías regionales y promover la inclusión digital. ${ }^{49}$

El tema de la ciberseguridad se ha constituido como un asunto de defensa prioritario para los países de la región, por cuanto ha pasado a involucrar el ámbito de la seguridad nacional, pudiendo afectar la estabilidad institucional y el desarrollo de los mismos. En suma, de manera creciente, el ciberespacio se ha pasado a apreciar como un nuevo escenario de conflicto entre los Estados, en la lucha por condicionar las decisiones políticas, a través de actividades ofensivas sobre la infraestructura crítica y organizaciones públicas y privadas sudamericanas (véase Aranda, Riquelme y Salinas, 2015). De hecho, a partir de las mencionadas actividades de ciberespionaje, ciertos países sudamericanos han avanzado en la conformación de comandos para los temas de ciberdefensa, como es el caso de

\footnotetext{
${ }^{49}$ La Declaración se encuentra disponible en http://alainet.org/active/66926 Recuperado en enero de 2015.
} 
Argentina, Brasil y Ecuador. Incluso, Brasil ha anunciado la creación de una Escuela Nacional de Defensa Cibernética.

Teniendo como base todo lo anteriormente señalado, el Plan de Acción 2014 contempló la celebración de un Seminario Regional sobre Ciberdefensa, con el objeto de contribuir a generar capacidades para enfrentar los desafíos de las amenazas cibernéticas e informáticas del ámbito de la defensa. El evento se celebró entre los días 14 y 16 de mayo de 2014 en Buenos Aires, durante el cual las delegaciones reconocieron la importancia de trabajar en actividades concretas para generar una política de defensa cibernética a nivel regional. Asimismo, se acordó lo siguiente:

1. Crear un foro regional del Grupo de Trabajo de Ciberdefensa de los Estados Miembros, a fin de intercambiar conocimientos, experiencias y procedimientos de solución.

2. Establecer una red de contactos de autoridades competentes para el intercambio de información y colaboración de manera permanente.

3. Definir la plataforma y procedimientos de comunicaciones de la red de contactos.

4. Profundizar y sistematizar la reflexión sobre definiciones conceptuales de ciberdefensa y ciberseguridad.

En línea con lo anterior, la I Declaración de Cartagena de la Reunión de Ministras y Ministros del Consejo de Defensa Suramericano, celebrada en dicha ciudad colombiana el 15 de agosto de 2014, ratifica la importancia y la necesidad de construir conceptos comunes, una política en materia de ciberdefensa, y exhorta a lograr avances concretos al Grupo de Trabajo de Ciberdefensa, en coordinación con el Grupo de Trabajo de Telecomunicaciones de COSIPLAN.

Durante la reunión de Cartagena, el Ministro de Defensa colombiano, Juan Carlos Pinzón, destacó "la construcción de conceptos comunes para desarrollar políticas en materia de ciberdefensa. Este es un tema que nos genera un reto común y que 
demanda ese trabajo integrado". ${ }^{50}$ En la misma ocasión, la Ministra de Defensa de Ecuador, María Fernanda Espinoza, planteó que "Nos hemos propuesto avanzar en la ciberdefensa con una propuesta regional que nos permita una mayor seguridad en nuestras comunicaciones." Asimismo, consideró que una de las principales bases para la consecución de la paz regional es la "construcción de la ciberpaz". ${ }^{51}$

Es necesario también subrayar que, además de las iniciativas llevadas a cabo en el seno del Consejo, ello no ha sido óbice para que los países hayan avanzado igualmente por el camino bilateral en el terreno del enfrentamiento de las amenazas sobre la ciberdefensa. Es el caso de la cooperación planteada entre Argentina y Brasil, cuyo primer paso es el intercambio académico y de formación de militares de ambos países en las respectivas academias militares. ${ }^{52}$ De hecho, ambos países han sido los principales impulsores de la temática en el contexto multilateral regional.

\section{Hacia un pensamiento estratégico regional: El Centro de Estudios Estratégicos de Defensa (CEED) y la Escuela Suramericana de Defensa (ESUDE)}

Avanzar en la autonomía estratégica sudamericana requiere, como condición necesaria, del impulso de un pensamiento estratégico propiamente regional, que contribuya a definir objetivos y metodologías comunes en la materia. Este ha sido un tema especialmente complejo, atendidas las diversas apreciaciones y conceptualizaciones que mantienen los países miembros del Consejo, sobre el cual ya lleva un tiempo trabajando el CEED, radicado en la ciudad de Buenos Aires, y la recientemente instalada ESUDE, desde la ciudad de Quito.

\footnotetext{
${ }^{50}$ Véase http://www.sinembargo.mx/15-08-2014/1088912 Recuperado en enero de 2015.

51 Véase http://www.eluniversal.com.co/politica/ciberpaz-la-apuesta-del-consejo-dedefensa-suramericano-de-unasur-167816 Recuperado en diciembre de 2014.

$52 \quad$ Véase http://noticias.terra.es/mundo/latinoamerica/brasil-y-argentina-quierenciberdefensa-en-unasur,c1429f8413572410VgnCLD2000000ec6eb0aRCRD.html Recuperado en enero de 2015.
} 
Contribuye a la debilidad de esta temática en América del Sur, el que en las academias militares de los países predomina el estudio de autores europeos y americanos, que basan su reflexión en escenarios geopolíticos, históricos y bélicos divergentes con la realidad sudamericana, que se caracteriza por su condición de presentarse como una Zona de Paz. Autores notables en tal sentido son Karl von Clausewitz, Martin von Creveld, Ferdinand Foch, Edward Luttwak, André Beaufré, Basil Lidell-Hart, Rupert Smith y Alfred Mahan, entre otros. Tales pensadores analizan las complejas realidades de la guerra y la estrategia en los escenarios de Europa y Medio Oriente, entre otros, poniendo énfasis en la conducta conflictiva de los hombres y, por derivación, de los Estados, sobre la base de enfoques fuertemente vinculados con el paradigma Realista de las Relaciones Internacionales.

Ante este escenario, las labores del CEED y la ESUDE desde América del Sur, pueden constituir una valiosa oportunidad para repensar las realidades de la guerra y la paz, así como respecto del rol de los militares en un contexto regional marcado por el desarrollo de una comunidad de seguridad, donde prima la cooperación y la estabilidad interestatal, lo que representa una anomalía y un acervo relevante de América del Sur en el contexto mundial. Las características y funciones de ambas instituciones del Consejo de Defensa Suramericano se explican a continuación.

\section{EI CEED}

En marzo de 2009 los Ministros de Defensa de UNASUR aprobaron la creación del Centro de Estudios Estratégicos de Defensa (CEED), con el objeto de "generar un pensamiento estratégico a nivel regional, que coadyuve a la coordinación y la armonización en materia de políticas de Defensa en Suramérica". Dicho centro, que tiene su sede en Buenos Aires, ha cumplido una relevante labor en la promoción de un pensamiento estratégico y de una comunidad epistémica a nivel regional, mediante la producción de documentos y estudios en materias estratégico-militares. Según señala Alfredo Forti: 
"Se trata de la construcción endógena de pensamiento estratégico, orientada desde las necesidades específicas y el interés común de nuestros países, funcional al interés regional, entendido como el conjunto de los factores comunes, compatibles y complementarios del interés nacional de los países de UNASUR" (Forti, 2012: 292).

En la Declaración de Guayaquil, emanada de la II Reunión Ordinaria del Consejo de Defensa Suramericano -celebrada en Guayaquil en mayo de 2010-, se aprobó el Estatuto del CEED, el cual establece los siguientes objetivos para el organismo:

- Contribuir, mediante el análisis permanente, a la identificación de desafíos, factores de riesgo y amenaza, oportunidades y escenarios relevantes para la defensa y la seguridad regional y mundial, tanto en el presente como en el mediano y largo plazo.

- Promover la construcción de una visión compartida que posibilite el abordaje común en materia de defensa y seguridad regional, de los desafíos, factores de riesgo y amenaza, oportunidades y escenarios previamente identificados, según los principios y objetivos expuestos en el Tratado Constitutivo de la UNASUR y en el Estatuto del Consejo de Defensa Suramericano.

- Contribuir a la identificación de enfoques conceptuales y lineamientos básicos comunes que permitan la articulación de políticas en materia de defensa y seguridad regional.

Según plantea Verónica Gómez, el establecimiento del CEED se constituye como "uno de los más importantes productos de la confianza en la región, porque fue el resultado de un proceso de discusión franco y enriquecedor que nos permitirá contar con un espacio para la construcción endógena de pensamiento estratégico, orientado desde las necesidades específicas y el interés común de nuestros países". Según Gómez, como una instancia de apoyo del Consejo, en la tarea de promover un pensamiento estratégico a nivel regional, el trabajo del CEED representa "un desafío novedoso teniendo en cuenta la herencia de diversos 
enfoques nacionales, o de visiones extrapoladas de usinas de pensamiento extraregional" (Gómez, 2012: 373).

Hasta ahora, los trabajos del CEED se han concentrado en la generación de estudios e investigaciones en el área de las políticas defensa (sobre temas como medidas de confianza mutua, instituciones de la defensa en América del Sur, políticas de género, visiones compartidas en defensa y ciberdefensa) y prospectiva y estrategia, así como al establecimiento de relaciones interinstitucionales con contrapartes nacionales y la realización de conferencias y seminarios, donde la temática de los recursos naturales y su relación con la defensa regional ha ocupado últimamente un lugar prominente.

Entre los diversos documentos preparados por el CEED, cabe destacar el Registro Suramericano de Gastos Agregados en Defensa 2006-2010, que forma parte de las Medidas de Fomento de la Confianza Mutua acordadas por los países miembros de la UNASUR, y que corresponde a un informe oficial de las erogaciones que realizan los países de dicha entidad regional en materia de defensa, elaborado a partir de una definición común de gasto en defensa, una metodología técnica estandarizada de medición y un mecanismo anual de remisión de la información.

Alfredo Forti resume de la siguiente manera el aporte del CEED a la formación de un pensamiento estratégico regional:

"A través de la elaboración de diagnósticos propios sobre nuestras capacidades, fortalezas y debilidades, el Centro de Estudios Estratégicos de la Defensa se establece como un instrumento propicio para contribuir a estructurar un subsistema regional de defensa cooperativo, interoperable y, en función de la protección efectiva de los intereses comunes y compartidos, para la construcción de un verdadero sistema político subregional integrado, como el que pretende la UNASUR" (Forti, 2012: 292).

En una entrevista realizada al Director del CEED, el ex Viceministro de Políticas para la Defensa del Ministerio de Defensa del Perú, Iván Vega Loncharich, este 
señaló que dicho centro busca, de manera pragmática, avanzar en la construcción de consensos y conceptos comunes en materia de defensa en América del Sur, considerando "la diversidad de visiones que existen en la región". Según Vega, la idea de su gestión es "no tocar temas sensibles, para avanzar en temas comunes, con transparencia, más allá de las ideologías y los conflictos históricos". En la misma línea, el personero planteó que un punto de encuentro en la región es la protección de los recursos naturales, que pueden actuar como catalizador para avanzar en visiones comunes, ante un escenario internacional incierto en materia de riesgos y amenazas, donde América del Sur se presenta como una "Zona de Paz, con un bajísimo gasto en defensa y donde no existe una carrera armamentista", pero donde aún existen temas pendientes, como lo es la debilidad que se aprecia en el plano de la investigación y desarrollo en defensa. ${ }^{53}$

\section{La ESUDE}

La ESUDE, cuya secretaría funciona en la sede de la UNASUR en Quito, fue el fruto del Grupo de Trabajo integrado por Argentina, Brasil y Ecuador, respondiendo a la necesidad de generar conceptos y categorías propias sudamericanas, repensando las nuevas realidades estratégicas de la región, en el marco del proceso de integración en marcha y frente a la crisis del sistema interamericano de defensa. En sus orígenes, la ESUDE se concibió como un instrumento para afianzar la democracia en la región, favoreciendo una formación militar bajo valores humanistas, al mismo tiempo que impulsar la cooperación y la autonomía regional respecto de Estados Unidos. ${ }^{54}$

Su creación deriva del compromiso asumido en el Tratado Constitutivo de la UNASUR que, en su artículo $3^{\circ}$ establece como uno de sus objetivos "el intercambio de información y experiencias en materia de defensa". Dicho mandato fue luego incorporado en el Estatuto del CDS, donde se asume como un objetivo específico, entre otros, el "Avanzar en la construcción de una visión compartida

${ }^{53}$ Entrevista realizada el 1 de diciembre de 2016 en Madrid, España.

${ }^{54}$ A este respecto, véase la nota "La escuela militar de UNASUR". Deutsche Welle, 16 octubre 2016. Disponible en http://www.dw.com/es/la-escuela-militar-de-unasur/a18000231 Recuperado en octubre de 2014. 
respecto de las tareas de defensa" y "Fomentar el intercambio en materia de formación y capacitación militar, facilitar procesos de entrenamiento entre las fuerzas armadas y promover la cooperación académica de los centros de estudios de defensa".

La creación de la ESUDE se aprobó en la reunión del CDS celebrada en febrero del año 2014 en Paramaribo, Surinam, con el objeto de establecer un centro regional de altos estudios, destinado a la capacitación de civiles y militares en asuntos de seguridad y defensa regional que, en último término, favoreciera la generación de una identidad propia y un pensamiento estratégico propiamente sudamericanos, respetando las particularidades de cada país miembro, y avanzando en la construcción de una visión regional en defensa. Asimismo, pretende promover y articular los intercambios entre los institutos y academias nacionales, civiles y militares, de los países miembros.

La ESUDE fue inaugurada en 2015, con motivo del octavo aniversario de la UNASUR. En el evento, el Secretario General de la instancia sudamericana, Ernesto Samper, resaltó la importancia de la creación de la ESUDE, reconociendo que "esta escuela pretende ser algo distinto de lo que fue la Escuela de las Américas. Esperemos que sea una escuela no para preparar nuestros ejércitos para las guerras, sino para prepararnos para la paz"55. El primer Secretario del organismo nombrado es el académico brasileño Jorge Antonio Ramalho.

Entre los objetivos de la ESUDE está el "contribuir a la consolidación de los principios y objetivos establecidos en el estatuto del CDS, a través de la formación y capacitación, por medio de la docencia e investigación, de modo a ampliar la confianza mutua, a favorecer el avance de una cultura de defensa común y a perfeccionar las condiciones de seguridad en América del Sur", además de "ser una institución reconocida internacionalmente por la capacidad de producir conocimiento, de formar elites civiles y militares en el campo de la defensa, y de

\footnotetext{
${ }^{55}$ Véase la nota de prensa "En su octavo aniversario: UNASUR consolida la Escuela de Defensa Suramericana" (17 de Abril de 2015). Disponible en: http://www.unasursg.org/es/node/218 Recuperado en julio de 2016.
} 
contribuir para el gradual y progresivo acercamiento de los países suramericanos hacia una identidad común en materia de defensa" ${ }^{\text {" }}$.

La ESUDE se constituye como una instancia académica de carácter permanente, cuyos contenidos de estudio giran en torno a tres áreas: Integración Regional y Cooperación Internacional en materia de Defensa; Defensa y Seguridad Regional; y Desarrollo y Participación Ciudadana y su relación con la defensa y seguridad regional. Debido a la cercanía entre las funciones específicas de ambas instituciones, el funcionamiento de la ESUDE supone una estrecha interacción con el CEED, en el favorecimiento de una identidad sudamericana y una visión común sobre la defensa regional. Según se señala en un documento preparado por el Ministerio de Defensa Nacional de Ecuador,

\begin{abstract}
"Mediante un abordaje académico de temáticas estratégicomilitares, la ESUDE complementa la dimensión institucional en la construcción de una identidad suramericana, y coadyuva a la generación de consensos que fortalezcan la cooperación regional en defensa, la difusión de los contenidos en la perspectiva estratégica y la doctrina de defensa suramericana" (Ministerio de Defensa Nacional del Ecuador, 2014: 183).
\end{abstract}

En una entrevista realizada al primer Secretario de la ESUDE, Antonio Ramalho, este señaló que, por el momento, la ESUDE pretende constituirse "como un instrumento de generación de confianzas, que tiene como horizonte el avanzar hacia un pensamiento estratégico regional". Es decir, no todavía como un foro de definición de una política o doctrina de defensa regional, sino "como un foro de diálogo y conocimiento mutuo". ${ }^{57}$

Hasta ahora, las áreas prioritarias de trabajo de la ESUDE se concentran en los conceptos que existen en la región sobre seguridad y defensa, institucionalidad de la defensa y escenarios de seguridad de la región y el mundo, entre otros, temas

56 La Misión y Visión de la ESUDE están disponibles en http://esudecds.unasursg.org/index.php/estatutos Recuperado en julio de 2016.

${ }^{57}$ Entrevista realizada el 30 de noviembre de 2016 en Madrid, España. 
sobre los cuales debe aprovechar la producción académica generada por el CEED, así como coordinar su trabajo con las academias nacionales presentes en la región. Dicha labor se enmarca de manera predominante en el cuarto eje del CDS, relacionado con "Formación y Capacitación".

Resumiendo lo hasta aquí expuesto, desde el Ministerio de Defensa Nacional del Ecuador, se señala que el "...interés compartido por los países suramericanos de crear la Escuela Suramericana de Defensa ha estado presente en el Consejo de Defensa Suramericano desde su conformación", constituyéndose la ESUDE como "un centro de altos estudios a nivel de posgrado para la formación y capacitación de civiles y militares en materia de defensa y seguridad regional, y un medio común de articulación de redes académicas entre las instituciones nacionales de los Estados miembros del CDS" (Ministerio de Defensa Nacional del Ecuador, 2014: 180). Sobre esta base:

"La constitución de la ESUDE contribuye a la difusión de la naturaleza, funciones, objetivos y actividades del CDS, entre las instituciones de formación y los diversos niveles institucionales de los países suramericanos, desarrollando un enfoque integral y coordinado para la capacitación de civiles y militares sobre política e institucionalidad de defensa en la región suramericana" (Ministerio de Defensa Nacional del Ecuador, 2014: 181).

En consecuencia, mediante un abordaje académico de temáticas estratégicomilitares de América del Sur y el mundo, la ESUDE complementaría la dimensión institucional del Consejo de Defensa en pos de la construcción de una identidad suramericana, apoyando la generación de acuerdos que fortalezcan la cooperación regional en defensa, la difusión de estudios estratégicos y la eventual generación de una doctrina de defensa propiamente suramericana (véase Ministerio de Defensa Nacional del Ecuador, 2014: 183). 


\section{c) ¿Hacia una estructura institucional más densa? El papel de los recursos naturales}

El Consejo de Defensa Suramericano desde un principio se propuso como una entidad flexible desde el punto de vista institucional, destinada a canalizar los esfuerzos de cooperación en defensa que llevan a cabo los países de la UNASUR, no constituyéndose como un mecanismo de resolución de conflictos, sino meramente como un foro destinado a favorecer un ambiente de paz y seguridad en la región.

No obstante, distintos hechos y situaciones han planteado la discusión en su interior, respecto de un eventual cambio de la estructura flexible y cooperativa con que originalmente se concibió el CDS, hacia una estructura institucional más densa, que se acerque a un mecanismo colectivo de seguridad, tipo OTAN. Este debate ha resultado apuntalado desde Argentina, ante la fuerte presencia militar británica en el Atlántico Sur, así como desde Brasil, en resguardo de los recursos del extenso territorio de la Amazonía y la denominada Amazonía azul.

En este orden de ideas, cabe destacar que, entre el 9 y 10 de junio de 2014, se celebró en Buenos Aires la Conferencia "Defensa y Recursos Naturales", organizada por el Ministerio de Defensa de Argentina, la Secretaría General de la UNASUR y el Centro de Estudios Estratégicos de Defensa (CEED). Entre otras actividades, durante el evento se analizó el texto "La defensa y los recursos naturales en Suramérica. Aportes para una Estrategia Regional", presentado por el argentino Alfredo Forti, entonces Director de esta última institución. El documento postulaba la necesidad de avanzar en un esquema de defensa regional para la protección de los recursos naturales, fundado en la "cooperación hacia dentro" y la "disuasión hacia afuera". Esto último implicaría que las capacidades militares y de defensa deberían fundirse en una sola cuando sea necesario proteger los recursos de América del Sur, ante eventuales amenazas de terceros Estados (CEED, 2014).

El encuentro concluyó con una declaración que destaca a los recursos naturales como un activo estratégico común regional y señala que garantizar la soberanía y la protección de los mismos es un interés colectivo de los países. Esta apreciación 
es coherente con el interés argentino en su reclamación territorial de las Islas Malvinas; Georgias del Sur y Sandwich del Sur y, especialmente, en los recursos energéticos situados en el área. Y también es coherente con el interés de Brasil de proteger los recursos del Amazonas (Riquelme y Rivera, 2014), en el contexto de un fuerte reenfoque en sus definiciones de las amenazas a la seguridad del país. En este último país, la Política de Defensa Nacional de 1996 planteaba que la región del Amazonas constituía la más relevante prioridad estratégica, dejándola al centro de las labores de las tres fuerzas armadas, considerando la existencia de numerosas amenazas vinculadas con el narcotráfico, minería ilegal, tala ilegal de árboles, comercio de especies animales y tráfico de armas, entre otros (véase Herz, 2010: 397-398).

La presencia militar británica en el Atlántico Sur y la defensa de los recursos naturales de la región han estado al centro de las discusiones sobre los nuevos lineamientos que debiera seguir el Consejo de Defensa Suramericano. Tal reflexión ha tenido como antecedente una serie de ocasiones en que el desaparecido presidente venezolano, Hugo Chávez, planteó la necesidad de establecer una OTAS, una suerte de OTAN sudamericana, bajo una perspectiva fuertemente antiimperialista dirigida contra Estados Unidos (Alda, 2012 a), debate sobre el cual también se pronunció en su momento el Presidente de Bolivia, Evo Morales.

Sin embargo, como se señaló anteriormente, el Consejo de Defensa Suramericano se concibió desde su establecimiento como una instancia flexible de consulta y cooperación en el terreno defensivo, antes que como un acabado mecanismo de seguridad colectiva. Aunque las opiniones en la región varían según los países. Avanzar hacia una instancia colectiva ha contado, aunque con vaivenes, con opiniones favorables en países como Bolivia y Venezuela. Por otro lado, Chile, Colombia y Perú se inclinan por un esquema más moderado de corte cooperativo. Brasil ha sido oscilante al respecto. Hasta ahora, la diversidad de apreciaciones que mantienen los países respecto a las amenazas que enfrenta la región ha dificultado el alcance de posiciones comunes, aunque el tema de los recursos naturales se ha presentado como una oportunidad de avanzar en los consensos. 
En consideración de lo antes señalado, Sanahuja y Verdes-Montenegro sostienen que frente a "la dificultad de consensuar un enemigo regional común y los medios para combatirlo, pareciera que se ha optado por securitizar los recursos naturales y la biodiversidad a través de un movimiento de securitización, que alerta respecto de potenciales amenazas extrarregionales (Sanahuja y Verdes-Montenegro, 2014: 520).

Es decir, el carácter impreciso de las amenazas que se ciernen sobre la región ha decantado en la apreciación de los recursos naturales como objeto a proteger, idea que ha sido fuertemente impulsada desde Argentina y Brasil. Variados estudios del CEED han abordado la protección de los recursos naturales y la biodiversidad de América del Sur como asuntos "estratégicos" para la región, reflejando una visión geopolítica extendida entre ciertos países, especialmente de la vertiente atlántica (sin dejar de lado el caso de Ecuador), donde se prevé un mundo que estará caracterizado por la escasez y la lucha por los recursos, relacionadas con el control foráneo sobre el petróleo, el agua, y los recursos minerales y/o agroalimentarios y donde la región de América del Sur estará al centro de los intereses mundiales, como un área rica en tales recursos. Con la progresión de estas concepciones sobre la seguridad regional, "el CDS pareciera estar adoptando una versión actualizada de un enfoque geopolítico basado en los recursos muy arraigado en el pensamiento estratégico militar brasileño y compartido por militares argentinos y de otros países" (Sanahuja y VerdesMontenegro, 2014: 505).

Según Sanahuja y Verdes-Montenegro, en el pasado esta visión geopolítica estaba centrada en la Cuenca Amazónica, pero los descubrimientos de reservas de petróleo por Brasil han generado fuertes demandas de su cúpula militar para reforzar el poder naval y aéreo de este país, adquiriendo submarinos de propulsión nuclear y nuevo equipo aéreo y naval, visión que ha reforzado las tradicionales demandas de Argentina sobre las islas Malvinas. Últimamente, la preocupación estratégica por la protección de los recursos naturales se ha extendido, de tal modo, de la Cuenca Amazónica a la Cuenca de la Plata y el Caribe. Así las cosas, "A partir de esta geopolítica de los recursos se plantea que UNASUR ha de construir un espacio geopolíticamente integrado que garantice el 
acceso y dominio de sus miembros frente a potenciales amenazas extrarregionales (Sanahuja y Verdes-Montenegro, 2014: 505).

Sin perjuicio de lo anterior, la discusión a este respecto no se asoma fácil en el Consejo de Defensa, atendidas las divergentes conceptualizaciones y apreciaciones de los países sobre esta temática, así como las asimetrías que se observan en la región en materia defensiva, donde sobresale claramente el poder de Brasil. Pero tales dificultades no deben obstaculizar este debate, especialmente valioso ante el escenario crecientemente multipolar que se aprecia a nivel internacional, donde el papel que puedan cumplir los mecanismos regionales en materias de paz y seguridad resulta especialmente trascendente, tal como lo señala el capítulo VIII de la Carta de Naciones Unidas. Desde luego, cualquier cambio que eventualmente se instale en el Consejo en tal sentido, será muy gradual, en virtud del principio del consenso que rige a la UNASUR.

\section{d) La participación en el Consejo de Defensa Suramericano y las políticas exteriores y de defensa}

Un tema que aún no ha sido convenientemente aquilatado en la literatura, es el aporte que ha significado la participación en el Consejo de Defensa Suramericano, para la creciente coordinación de las políticas exteriores y de defensa en los países miembros. Esta temática ha sido especialmente compleja en la región, dadas las divergentes culturas institucionales entre los Ministerios de Relaciones Exteriores y de Defensa. En palabras de Héctor Saint-Pierre:

“...la Política Externa es la resultante de la dialéctica de las voluntades del ejecutivo y de las burocracias específicas (Diplomacia y Fuerzas Armadas). Cuando el ejecutivo no tiene una clara política para el relacionamiento externo del país, aquellas burocracias definen sus objetivos con cierta libertad, a veces coherentemente y otras con notorios desencuentros" (Saint-Pierre, 2012: 134). 
La globalización y la interdependencia han tenido efectos trascendentes tanto a nivel internacional, como en el ámbito doméstico de los Estados. Particularmente eminente, para los efectos del presente trabajo, resulta la proliferación de mecanismos de integración regional, como es el caso de la UNASUR y, en su marco, del Consejo de Defensa Suramericano.

Desde el punto de vista político y estratégico, un escenario globalizado e incierto tiene un impacto directo en la manera en que los países perciben sus amenazas, riesgos y vulnerabilidades, determinando, en consecuencia, el modo en que éstos planifican y elaboran sus políticas de seguridad y defensa. Ello resulta especialmente necesario al momento en que los países deciden participar en instancias de integración regional, tendiendo de manera decisiva a atenuar las reflexiones geopolíticas centradas en el concepto de la disuasión y los conflictos limítrofes y vecinales, para pasar a fortalecer, en su lugar, una nueva agenda basada en la cooperación con el entorno, y de cara al mundo global.

En tal escenario, las políticas exteriores y de defensa, como cualquier otra, evolucionan $y$, en ese proceso, algunos elementos pueden modificarse en la medida que varíen las condiciones que motivaron su elaboración, cuestión que ha sido especialmente notable en el plano sudamericano, donde diversos países, participando de la agenda regional, han demostrado de manera sostenida su disposición por insertarse en las corrientes globales. Lo anterior ha evidenciado la necesidad de articular el respectivo trabajo de los Ministerios de Relaciones Exteriores y de Defensa, avanzando en posiciones comunes que no siempre es fácil armonizar, dadas las muy diversas culturas organizacionales. Esta situación ha sido abordada, por ejemplo, en el Libro de la Defensa Nacional de Chile del año 2010, el cual destaca el particular interés y conveniencia de estrechar la vinculación y coordinación entre las políticas exterior y de defensa, las que deben complementarse y potenciarse mutuamente, actuando la segunda en respaldo de la primera (Ministerio de Defensa Nacional de Chile, 2010: 112).

El renovado contexto político actual, que manifiesta una tendencia creciente a regionalizar las preocupaciones de los Estados en materia de paz y seguridad, ha impactado fuertemente en el modo en que los países han asumido su conducción política en el plano de la defensa. La complejidad de esta renovada realidad 
requiere, como condición sine qua non, de una mirada integral y multidimensional que, en el plano de las políticas públicas, se expresa en un acentuado trabajo interministerial e intersectorial. En tal contexto, la participación en el Consejo de Defensa Suramericano se ha constituido para los Estados miembros en una oportunidad para incrementar y consolidar las relaciones entre las políticas exteriores y de defensa, lo que ha sido particularmente evidente en el caso de Brasil, que cuenta desde 2008 con una Estrategia de Defensa Nacional, que ha logrado aunar las visiones entre tales políticas públicas, así como entre éstas y su política de desarrollo, tema sobre el cual se volverá más adelante.

Sin embargo, el acomodo de tales políticas públicas no ha sido un asunto fácil en América del Sur. Los actores políticos, civiles y militares han declarado en variadas ocasiones la necesidad imperiosa de superar las descoordinaciones entre los sectores tocantes a cada una de ellas. Esto ha sido un asunto complejo en la región, donde muchos países han debido realizar complejos procesos de transición democrática, tras dilatados períodos de regímenes militares. Las dificultades parecen derivar de la experiencia histórica de ambos sectores, así como de su muy distinta organización y composición. Esto plantea que tanto las percepciones y prioridades, así como los fines e intereses, sean distintos o tengan diferentes enfoques en ambas esferas, como efecto de la desigual formación y capacitación profesional, de la visión de los problemas y el modo de enfrentarlos, así como respecto del acceso a fuentes de información (Fuentes, 1995).

Otro desafío para lograr una adecuada coordinación entre la política exterior y la política de defensa es la ausencia, en muchos países, de una visión estratégica, que integre armónicamente a ambas esferas, en lo que podría denominarse una gran estrategia nacional. La experiencia internacional brasileña puede entregar algunas luces en la materia.

Como se señaló anteriormente, la inserción internacional de Brasil ha logrado éxitos notables a partir de la publicación de su Estrategia Nacional de Defensa del año 2008, en la que se señala que la estrategia nacional de defensa es inseparable de su estrategia de desarrollo y de su política exterior. Con esta base, el gigante sudamericano fue uno de los principales impulsores del establecimiento y desarrollo del Consejo de Defensa Suramericano. 
Para los países de la región, los que de manera transversal, aunque con matices, han declarado en numerosas ocasiones su vocación regionalista, la participación en el Consejo ha significado la puesta en práctica de la prioridad latinoamericana o sudamericana (en el caso brasileño) delineada desde las Cancillerías con el estrecho apoyo del sector defensa.

La participación de los países en dicho Consejo se ha constituido en una instancia relevante para apuntalar la coordinación entre los ministerios de Relaciones Exteriores y de Defensa -cuyos integrantes forman parte de las delegaciones que participan en las diversas reuniones del organismo- con el objeto de trabajar en torno a la integración regional en el plano defensivo, al tiempo de proyectar internacionalmente a América del Sur, sin dejar de lado aquellos aspectos relacionados con el impulso de la estabilidad de la región, apoyando la generación de confianza entre los miembros y previsibilidad en las conductas, lo que consecuentemente ha disminuido la incertidumbre y reforzado la estabilidad de las relaciones, lo que resulta coherente con el modelo de desarrollo abierto al mundo que han asumido ciertos miembros de la UNASUR, particularmente aquellos vinculados a la Alianza del Pacífico. 


\section{7.- El papel de los liderazgos en la constitución y desarrollo del Consejo de Defensa Suramericano}

Desde la Teoría de la Integración, el papel de los líderes en los procesos de integración ha sido bastante analizado. Bajo esta perspectiva, se postula que, para el avance de la integración, resulta imprescindible un área focal o centro de poder que impulse el proceso y actué como líder (Magariños, 2000: 33). Las asimetrías de poder podrían jugar un rol positivo para un proceso integrativo, en la medida que contribuyen a canalizar el poder, apoyando la configuración de los necesarios liderazgos regionales.

Apoyando tales argumentos, Charles Kupchan plantea el modelo de la "unipolaridad benigna". Este concepto de refiere a la generación de una estructura jerárquica regional, en la cual un centro geográfico preponderante establece un modelo de relacionamiento e influencia sobre la periferia, donde el centro canaliza de manera deliberada la manera en la cual el poder es ejercido en las formaciones regionales (Kupchan, 1998). Siguiendo a este autor, a lo que se apunta, es que la unipolaridad regional promueve el orden y la estabilidad, a través de las asimetrías de poder y la jerarquía que de ellas se derivan. El predominio de un liderazgo desalentaría el desorden, habilitando al líder a subrayar las instituciones y normas del orden regional. Así, mientras la equivalencia de poderes (simetría) podría alentar la competencia y la disputa por el liderazgo, las asimetrías producirían jerarquía y un estable modelo de relaciones entre el centro y la periferia regional.

Sin perjuicio de lo anterior, puede sostenerse que la débil consolidación de los ensayos de integración de América del Sur puede explicarse por la carencia de un liderazgo firme, constante y definido, razón por la cual la experiencia sudamericana todavía parece lejos del ejemplo europeo. La región actualmente se aprecia como un espacio geopolítico con un centro mayor, que sería Brasil, junto a otros actores de relevancia, como es el caso de Argentina y Venezuela (Aunque éste último país, al momento en que se escriben estas líneas, se encuentra en una severa crisis política y económica), así como nuevos actores pujantes, como son Chile, Colombia y Perú, que conjuntamente con México han constituido recientemente la Alianza del Pacífico, una iniciativa de corte fuertemente 
liberalizador, que pretende promover la libre circulación de bienes, servicios, capitales y personas entre sus países miembros y entre éstos y los mercados asiáticos.

En el contexto crecientemente multipolar que se está delineando en el mundo, diversos procesos de integración regional han cobrado una alta connotación en la política internacional. No obstante, según sostiene Detlef Nolte, si bien estos procesos promueven el ascenso de potencias regionales, también contribuirían a la emergencia de conflictos por el liderazgo regional o subregional (Nolte, 2007: 17).

En los términos planteados por Félix Peña (2008: 26), un liderazgo regional conlleva distintos conceptos entrelazados. Primero, el concepto de relevancia, que se relaciona con el grado de gravitación (poder, recursos, mercado, influencia y prestigio) que un país puede tener para definir la manera como son encaradas cuestiones importantes de la agenda regional. Luego, es preciso definir el concepto de protagonismo, lo cual significa que un país, especialmente si es relevante, procura tener una presencia activa como actor en las cuestiones importantes de la agenda de la región. Por último, se debe subrayar que el concepto de liderazgo implica el que un país opte por ser un protagonista activo, cualquiera sea su relevancia, y contribuir a las cuestiones con una visión estratégica y con iniciativas aceptables para los demás países.

Bajo la perspectiva de este trabajo, este último punto resulta especialmente relevante, por cuanto el liderazgo de un país exige del reconocimiento por parte de otros Estados de la región y fuera de ella, siendo este punto uno de los claves para entender la carencia de un liderazgo regional definido en América del Sur donde Brasil, el país que debiera constituirse como el líder natural de la integración, todavía no cuenta con el respaldo unánime del resto de los países sudamericanos.

Analizando las políticas exteriores de los países de América Latina, Gian Luca Gardini distingue dos enfoques principales, aunque no excluyentes, que han guiado el accionar internacional de los Estados: el pragmatismo y la ideología (Gardini, 2011). Según Gardini, una política exterior ideológica enfatiza las acciones basadas en principios y doctrinas, se rige por resultados de corto plazo y 
se relaciona directamente con la visión de los líderes personalistas. Por su parte, una política exterior pragmática, se caracteriza por sus ideas y propuestas prácticas, siendo prioritaria la acción antes que las doctrinas y la experiencia por sobre los principios. Brasil sería un buen ejemplo de un país con una política exterior de carácter pragmático, mientras que Venezuela se podría identificar por su accionar externo de signo ideológico. Sin embargo, cabe hacer notar que las tendencias ideológicas y antiimperialistas de Venezuela no se han constituido en un obstáculo para la alta dosis de pragmatismo que ha regido sus relaciones comerciales con Estados Unidos, uno de sus principales compradores de petróleo. En 2011 Juan Gabriel Tokatlián planteaba que existían dos países con alto perfil en la región y con la clara voluntad de influir y proyectarse internacionalmente: Brasil y Venezuela. Tales países reflejaban "...variantes de lo que Robert A. Pape ha llamado soft balancing, uno en un estilo bastante ponderado (Brasil), el otro de forma más provocadora (Venezuela)" (Tokatlián, 2011: 150-151). En la práctica, según el citado autor argentino,

"Brasil despliega una estrategia de oposición limitada, consistente en una política mixta hacia Estados Unidos en la que se combinan desacuerdo y colaboración, concertación y obstrucción, deferencia y resistencia. Por su parte, Venezuela procura una estrategia de desafío en la que impulsa políticas de distanciamiento y rechazo a Estados Unidos para contrabalancear su poder, tanto en el terreno mundial como en el campo regional" (Tokatlián, 2011: 151).

Lo cierto es que los papeles de liderazgo perseguidos en su momento por Brasil y Venezuela respondían a visiones distintas sobre el nuevo escenario multipolar que se desarrolla en el mundo. Por lo demás, cabe señalar que el reciente cambio de gobierno en Brasil ha impactado fuertemente en la presencia internacional brasileña y en su protagonismo en el plano multilateral, lo que también ha tenido efectos en su posicionamiento ante variadas materias de discusión global. En tal sentido, en un contexto político doméstico marcado por la crisis (donde han tenido un especial protagonismo los graves casos de corrupción), la agenda interna ha 
desplazado a la política exterior, lo que ha contribuido a un cierto ensimismamiento internacional del gigante sudamericano. Ello ha implicado la pérdida de protagonismo de Brasil en la agenda regional y global, afectando igualmente sus posibilidades de presentarse como un líder en América del Sur.

Por otro lado, cabe anotar que el liderazgo de Venezuela fue severamente afectado por la muerte del Presidente Hugo Chávez, cuyo carisma no ha podido replicar su sucesor Nicolás Maduro, estando su gobierno, al momento en que se escriben estas líneas, en una severa crisis institucional y económica que le ha implicado, entre otros, la suspensión indefinida del MERCOSUR. Incluso Heinz Dieterich, quien fuera uno de los mentores de Chávez e ideólogo del denominado Socialismo del siglo XXI, no ha dudado en criticar severamente el despliegue de Maduro, acusándolo de megalomanía y escasa visión política y económica, por cuanto "No entiende nada de economía. Creyó las tonterías de lo que su gabinete le vendió como socialismo", al revés de Chávez, que "Tenía capacidad de análisis, de conducción y un precio petrolero a su favor. Y, por supuesto, era pragmático" ${ }^{58}$ No obstante lo antes señalado, puede plantearse que, por su dimensión relativa y por generar menos resistencias, Brasil es el país que posee mayores posibilidades, responsabilidad y potencialidad para influir $e$ incidir en las cuestiones regionales ${ }^{59}$, aunque igualmente por necesidad requiere para ello del acuerdo de otros actores relevantes, como es el caso de Argentina, Colombia, Chile, Perú y, desde luego, Venezuela. Como sostiene Tokatlián:

“...nadie puede hoy tomar una decisión trascendental de política exterior sin mirar a Brasilia. Brasil es un interlocutor obligado en

\footnotetext{
58 "La economía está en coma, pero Maduro no comprende lo que pasa". La Tercera, 4 mayo 2016. Disponible en http://www.latercera.com/noticia/ex-mentor-de-hugo-chavez-laeconomia-esta-en-coma-pero-maduro-no-comprende-lo-que-pasa/ Recuperado en mayo de 2016.

${ }^{59}$ A este respecto, se debe destacar que Brasil posee 8,5 millones de $\mathrm{Km} 2$, ocupa la mitad de América del Sur, su población alcanza los 201 millones de habitantes y su PIB representa más del 30\% del PIB regional, sin dejar de mencionar que la diplomacia de Itamaraty posee un renombre internacional por su alto profesionalismo (véase Einaudi, 2011).
} 
las relaciones exteriores de todos los países del área, al tiempo que su notoria visibilidad internacional y gradual reconocimiento mundial le ofrecen a América Latina una oportunidad relevante para concitar mayor atención global" (Tokatlián, 2011: 150).

La "unipolaridad benigna" regional descansa en un proceso de toma de decisiones consensual con los países periféricos intrarregionales. Hasta ahora este tema resulta especialmente complejo, considerando que Brasil no cuenta con el apoyo unánime de los países de la región respecto de su eventual liderazgo, y tampoco ha demostrado una voluntad sostenida por configurarse como un conductor de la integración.

Otros temas que pueden afectar el posicionamiento regional e internacional brasileño son la enorme desigualdad en la distribución de los ingresos a nivel interno, los manifiestos signos de inestabilidad democrática, los numerosos casos de corrupción -que de hecho están dañando el soft power del gigante sudamericano-, así como su enorme predominio económico regional, ${ }^{60} \sin$ olvidar la decisión de construir un submarino nuclear, lo que ha causado serias precauciones en su entorno.

Considerando lo antes señalado, este capítulo aborda el rol de Brasil, Chile y Ecuador en el CDS, en tanto países que formaron parte del Grupo de Trabajo para la conformación del mismo en 2008. Al final también se analiza, el papel desempeñado por Argentina, que se aprecia como un liderazgo emergente en el seno de dicho organismo regional.

\section{a) El papel de Brasil}

El gigante sudamericano ha sido considerado como parte del mundo emergente al menos desde el año 2001, cuando un informe de Goldmann Sachs lo incluyó en la

\footnotetext{
${ }^{60}$ Según el World Economic Forum, Brasil corresponde a la novena economía mundial, con una economía de unos 1.8 trillones de dólares. Véase el documento "las diez economías mayores del mundo en 2017'. Disponible en https://www.weforum.org/es/agenda/2017/03/las-10-mayores-economias-del-mundo-en-

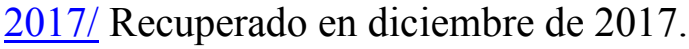


categoría BRIC, conformada por los cuatro mercados emergentes que, considerando la combinación de sus dinámicas economías, eclipsarían el predominio de los países ricos del denominado Norte, preponderando en la economía global hacia el año 2050. Como señalan Lechini y Giaccaglia, la ex colonia lusitana constituye un país continental, que integra dos cuencas hidrográficas de importancia, como son la del Amazonas y la de La Plata; siendo el quinto país más grande del mundo, después de Rusia, China, Canadá y Estados Unidos, con una población total de unos 174.633.000, más que la de Argentina, Bolivia, Chile, Paraguay, Perú y Uruguay en su conjunto (Lechini y Giaccaglia, 2007: 75).

En el continente sudamericano, Brasil se caracteriza por haber demarcado todas sus fronteras vecinales en los inicios del siglo $X X$, no teniendo actualmente reclamos territoriales desde y hacia su entorno, siendo incluso calificado por algunos investigadores como una potencia regional "benigna" o "estabilizadora" (Gratius, 2008).

Según Federico Merke, Brasil despliega una política exterior en tres geografías. La primera es la que vincula al Sur con el Norte, donde destaca la relación con Estados Unidos. La segunda tiene que ver con la dinámica Sur-Sur, donde Brasil puede lograr una mayor proyección de poder e influencia, y que se concreta en iniciativas como IBSA y BRICS. La última geografía es América del Sur, donde resalta el liderazgo brasileño en la constitución de la Comunidad Sudamericana de Naciones (hoy UNASUR) y el CDS. Según Merke, las tres geografías demuestran una tendencia general en la política exterior del gigante sudamericano, tendiente hacia la ampliación y diversificación de su agenda internacional, abarcando temas como comercio, cambio climático, derechos humanos, seguridad internacional, migraciones y ayuda al desarrollo. Este proceso iría de la mano de otro, vinculado con la internacionalización de agencias estatales y empresas privadas brasileñas, lo que a su vez crearía nuevas bases de sustentación doméstica hacia su proyección en el ámbito de la política exterior y la política de defensa (Merke, 2012: 120).

Para Merke, en la dinámica Sur-Sur se aprecia un Brasil más reformista y con una mayor proyección de poder e influencia. Siendo un área con numerosas aristas, 
serían las esferas del comercio, la diplomacia y la asistencia al desarrollo las predominantes en la agenda. Según este autor, es en este eje donde el gigante sudamericano hace sus declaraciones más asertivas en torno a la necesidad de diseñar nuevos arreglos institucionales globales que aseguren un mayor nivel de desarrollo y democracia en el mundo. Asimismo, en este espacio Brasil encontraría relevantes oportunidades para ejercer influencia global, a través de la ayuda al desarrollo, las alianzas estratégicas y la participación en los distintos foros del mundo emergente (Merke, 2012: 122). A ello cabe agregar su activo papel en la Cumbre entre los países árabes y los de América del Sur (ASPA), y entre éstos y África (ASA). Todas estas tendencias, como parte de la llamada solidaridad periférica desde los teóricos de Itamaraty, "parece haberse radicalizado últimamente", señalaba Alain Rouquié el año 2011 (2011: 121).

En el mismo sentido, resulta relevante hacer notar que el accionar exterior de Brasil no depende tanto, como lo fue en el caso de la Venezuela de Chávez, de una coyuntura económica favorable o de la personalidad de un dirigente,

“..sino que representa más bien la manifestación contemporánea, adaptada al siglo XXI, de las aspiraciones históricas de un paíscontinente que es la novena economía mundial, quinta tal vez de aquí a 2025, y cuyo PIB es igual o superior al de la India o al de Rusia. Brasil, que ha conocido en los diez últimos años un ascenso fulgurante y que figura entre los grandes Estados emergentes..., ha sido desde el comienzo del siglo XX un Estado anti-statu quo y revisionista del orden internacional. En pocas palabras, quiere tener un mayor protagonismo y un papel reconocido en las instancias donde se toman las grandes decisiones internacionales" (Rouquié, 2011: 119).

Últimamente, considerando las aspiraciones de Brasil para formar parte activa de los debates actuales del multilateralismo global, destaca el activismo de este país sobre las nuevas conceptualizaciones acerca de la denominada Responsabilidad de Proteger, surgida a partir del informe presentado a las Naciones Unidas por la 
Comisión Internacional sobre Intervención y Soberanía de los Estados (ICISS, por su sigla en inglés), establecida en 2000 y liderada por el ex Canciller australiano Gareth Evans y el ex Asesor Especial del Secretario General de Naciones Unidas para África, Mahmoud Sahnoun, con el objeto de contribuir a poner freno a los desastres humanitarios y sobre los derechos humanos derivados de conflictos internos.

A este respecto, y ante los sucesos de Libia acontecidos a partir de la implementación de la Resolución 1973 del Consejo de Seguridad (de marzo de 2011), que tuvo como resultado no previsto en el mandato el cambio del régimen libio, el gigante sudamericano asumió una posición de liderazgo en el debate que se originó a nivel internacional, planteando nuevas formulaciones bajo el concepto de la "Responsabilidad al Proteger" (Responsibility while Protecting). Como sostiene el profesor Gilberto Rodrigues:

"En medio de un silencioso malestar entre diversos gobiernos que estuvieron en desacuerdo con la forma en que la Resolución 1973 fue implementada -inclusive China y Rusia- el gobierno brasileño sorprendió con un llamado a la responsabilidad al proteger" (Rodrigues, 2012: 170).

La primera vez que la iniciativa brasileña apareció públicamente fue en un artículo del Canciller Antonio Patriota, publicado en el periódico Folha de São Paulo el 1 de septiembre de $2011^{61}$. En el artículo, el Ministro Patriota afirmaba que:

"...para Brasil, lo fundamental es que, al ejercer la responsabilidad de proteger por la vía militar, la comunidad internacional, además de contar con el correspondiente mandato multilateral, observe otro precepto: el de la 'responsabilidad al proteger'. El uso de la fuerza solo puede ser utilizado como último recurso" (En Rodrigues, 2012: 175).

$\begin{array}{lllll}61 & \text { El } & \text { señalado } & \text { artículo está }\end{array}$ http://www1.folha.uol.com.br/fsp/opiniao/fz0109201107.htm. 
Como se aprecia, el artículo se refería clara y críticamente a la acción de la OTAN en Libia. En el mismo tenor se refirió la Presidenta brasileña Dilma Rouseff, durante el Debate General de la Asamblea General el día 21 de septiembre de 2011. En la ocasión la Presidenta introdujo el mencionado concepto en el terreno multilateral, poniendo un énfasis especial en el ámbito de la prevención, señalando que la diplomacia preventiva reduce los riesgos de conflicto armado y los costos humanos asociados a él. ${ }^{62}$ Esta pujanza de Brasil en el plano multilateral se ha constituido como una sección fundamental de su posicionamiento exterior.

Una de las fortalezas de Brasil es su diplomacia profesional y de prestigio internacional, cuyo símbolo es su Cancillería, Itamaraty. En su visión de largo plazo, la diplomacia brasileña ha tendido a supeditar su política regional a sus objetivos en el ámbito global. Lo anterior ha ido de la mano de un ingente accionar en el ámbito multilateral, como es el caso de la Organización Mundial del Comercio (OMC) y Naciones Unidas, donde ha procurado configurarse como un actor moderador de posiciones radicales y como puente entre los intereses de los denominados países del Sur y Norte. Por último, según sostienen Maria Regina Soares de Lima y Mónica Hirst,

"Además de sus esfuerzos por preservar una voz independiente en la comunidad internacional, el Brasil ha dado señales claras de

${ }^{62}$ Un mayor detalle de la noción propuesta por Brasil se encuentra en la Nota Conceptual Responsibility while Protecting: elements for the development and promotion of a concept, presentada mediante una carta al Secretario General de Naciones Unidas por la Representante Permanente de Brasil, Embajadora Maria Luisa Ribeiro Viotti, el 11 de noviembre de 2011. Según explica el documento, la iniciativa de Itamaraty no pretende sustituir a la Responsabilidad de Proteger, sino más bien complementarla a través de la creación de reglas más claras en los temas más polémicos, como otorgar el máximo de protección antes de intervenir, máximo de cautela y accountability ante el Consejo de Seguridad al intervenir. La propuesta de Brasil plantea que la aplicación de los pilares debe ser consecutiva, aplicándose primero la prevención y responsabilidad de los Estados, luego la cooperación internacional, para culminar con el tercer pilar relativo a las medidas coercitivas. Aunque para este país la aplicación de los mencionados pilares es una consecución lógica y no cronológica. 
que aspira a expandir sus roles y responsabilidades en la política regional, en las agendas del Tercer Mundo y en las instituciones multilaterales" (Soares de Lima y Hirst, 2007:88).

\section{El Consejo de Defensa Suramericano como parte de la sudamericanización de la política exterior de Brasil}

En el ámbito sudamericano, donde se concentra la presente investigación, es necesario referirse al proceso de sudamericanización de la política exterior de Brasil, puesta en marcha desde la década de los ochenta -aunque sus antecedentes remotos pueden remontarse al Barón de Rio Branco, símbolo de la diplomacia brasileña-, conjuntamente con el proceso de transición democrática que se desarrollaba en ese país, pero que cobró mayor vigor desde los noventa. Desde ese momento, en los gobiernos comenzó a revalorizarse a la región de América del Sur como trampolín de la proyección global de Brasil como potencia emergente, en tanto su poder, significativamente menor que otros BRIC, lo obligaría a contar con el apoyo de su entorno. Según señala Mónica Herz, "La política de Brasil hacia Sudamérica debe ser entendida en el contexto de la construcción de una estrategia de bloque teniendo en consideración la integración regional" (Herz, 2010: 395). En 2007, el entonces Vicecanciller brasileño, Samuel Pinheiro Guimarães, planteaba en el mismo sentido, que:

"América del Sur se encuentra, necesaria e inexorablemente, en el centro de la política exterior brasileña. A su vez, el núcleo de la política brasileña en América del Sur está en el Mercosur...Las características de la situación geopolítica de Brasil, esto es, su territorio, su ubicación geográfica, su población, sus fronteras, su economía, así como la coyuntura y la estructura del sistema mundial, vuelven la prioridad sudamericana una realidad esencial" (Pinheiro, 2007: 105-106). 
Bajo la perspectiva de Brasil, y por sobre la noción de América Latina, América del Sur corresponde a un subsistema internacional diferenciado, con lógicas y dinámicas propias, determinadas por una historia compartida y una contigüidad geográfica que, de manera pragmática, deja afuera a México y contiene la presencia estadounidense en la región. Como señala Merke, fue a comienzos de los ochenta y particularmente con el regreso de la democracia que Brasil comenzó un proceso notable de "sudamericanización" de su política exterior, por cuanto "La misma noción de América del Sur como espacio óptimo para pensar la integración regional tiene que ver con una intensa labor brasileña por hacer de esta región el espacio natural para su proyección de poder" (Merke, 2012: 123).

No obstante, sería la Presidencia de Luiz Inácio Lula da Silva la que otorgaría mayor visibilidad política a esta opción regional de la política exterior brasileña, como parte de las potencialidades que expresaba la cooperación Sur-Sur (véase Herz, 2010: 396-397), lo que iría de la mano de una estrecha "sintonía de las gramáticas militar y diplomática en su adecuación a la lógica de la política externa" (Saint-Pierre, 2012: 135).

En tal orden de ideas, cabe subrayar el papel mediador que ha asumido Brasil ante distintas crisis sufridas por países de la región, el impulso otorgado a la iniciativa para la Integración de la Infraestructura Regional Sudamericana (IIRSA), así como el liderazgo asumido en la Misión de Estabilización de Naciones Unidas en Haití (MINUSTAH), en el marco de más de cien años de relaciones pacíficas con sus vecinos sudamericanos, como Estado geopolíticamente satisfecho. Lo anterior resulta significativo, considerando que Brasil tiene fronteras con casi todos los países de Sudamérica, con la excepción de Chile y Ecuador. En palabras de Rouquié:

"Brasil, que representa más de $55 \%$ del PIB regional, se ha dedicado a construir desde 2000, junto con sus vecinos sudamericanos, un bloque continental del cual sería el principal motor y el primer beneficiario. Mientras Venezuela trata de resucitar, sin costo, un pasado de división ideológica del mundo, Brasil, con su liderazgo natural y su experiencia diplomática, ha 
anticipado un nuevo orden internacional menos asimétrico y más equilibrado en el cual se quiere inscribir como actor global (Rouquié, 2011: 122).

Lo anterior representa una oportunidad para la región en su pretensión de inserción y posicionamiento en el mundo multipolar. Para tal efecto, los países sudamericanos deberían aprovechar el posicionamiento brasileño y encauzarlo con los intereses regionales. Lo anterior podría "evitar el peligro de aventuras externas solitarias que, al aislar a Brasil, condenarían a sus vecinos a un permanente y amargo repliegue, además de impedir que América Latina ocupe un lugar destacado en el orden internacional del futuro" (Rouquié, 2011: 122).

No obstante, tampoco Brasil ha dado muestras claras de su voluntad por ejercer el liderazgo regional, lo que ha sido una constante en la política exterior de dicho país y que muchas veces ha sido interpretado como automoderación. En un lenguaje directo en tal sentido, se expresó en 2007 el Vicecanciller de Itamaraty, Embajador Samuel Pinheiro Guimarães, explicando que:

"...la solidaridad en los esfuerzos de desarrollo e integración es una idea central en la estrategia brasileña en América del Sur, así como la idea de que este proceso es un proceso entre socios iguales y soberanos, sin hegemonías ni liderazgos" (Pinheiro, 2007: 122).

Dando continuidad a este argumento, en abril de 2017 el Canciller Aloysio Nunes planteaba durante una entrevista, a propósito de la crisis política y económica que sacude a ese país, que "Brasil está en el camino de la recuperación, pero no de liderazgo, porque no es nuestra ambición. No queremos liderar a nadie, queremos ser amigos, pero en plena recuperación de la economía, de la estabilidad de nuestra moneda y de la búsqueda del equilibrio fiscal". ${ }^{63}$ Dicha postura ha sido

\footnotetext{
${ }^{63}$ Véase "Brasil está saliendo de ese hoyo en que fue metido por el populismo y la incompetencia”. El Mercurio, 16 abril 2017. Disponible en
} 
sostenidamente acompañada por un enfoque sobre la región que busca evitar los excesivos ideologismos, imprimiendo altas dosis de pragmatismo en la integración sudamericana.

Teóricamente, la relevancia de la región de América del Sur, en el marco de la política exterior brasileña, se sustenta en la denominada doctrina de los círculos concéntricos, según la cual los países limítrofes de Brasil forman parte de su "zona de influencia inmediata", mientras los demás sudamericanos pertenecen a su "zona de influencia directa". Según señala Federico Merke:

“...Brasil ha sido el principal constructor gramatical de América del Sur como una región cognitiva que necesita ser pensada como un todo. Itamar Franco sentó las primeras bases para la creación de una Comunidad Sudamericana de Naciones (hoy UNASUR); Fernando Henrique Cardoso realizó la primera Cumbre de Presidentes de Sudamérica; Lula creó en 2003 la Subsecretaría de América del Sur en la estructura de Itamaraty, y luego, a fines de 2007, introdujo la idea de un Consejo de Defensa Suramericano (CDS)" (Merke, 2012: 124).

En consecuencia, es posible plantear que el impulso de Brasil hacia la integración sudamericana responde a diversos intereses. Primero, la región se constituye como la base fundamental de su proyección internacional. Desde luego, apoyar la integración es una manera de incrementar la legitimidad de su aspiración fundamental, que se conecta con su pretensión por alcanzar un asiento permanente en el Consejo de Seguridad de Naciones Unidas. Un puesto en dicho órgano debe contar, como condición sine qua non, con la anuencia de los países de la región. Desde luego, este es un punto débil de su posicionamiento internacional.

Ello también explica el liderazgo que mantuvo Brasil en el marco de la MINUSTAH, donde trabajó conjuntamente con sus principales países afines en

http://www.economiaynegocios.cl/noticias/noticias.asp?id=352795 Recuperado en abril de 2017. 
la región, procurando demostrar su capacidad de proyectar poder a nivel internacional, al mismo tiempo que legitimar una intervención militar a los ojos de otros países menos proclives del entorno (Malamud, 2011: 10). También, la opción por apoyar la integración regional pretende dejar fuera otros actores extrarregionales, como es el caso de Estados Unidos, pero también a México. ${ }^{64}$ Ésa es la razón de favorecer la integración a nivel sudamericano antes que latinoamericano. Además, el apoyo al establecimiento del Consejo de Defensa Suramericano se vincula igualmente con la necesidad brasileña de impulsar su desarrollo industrial en el ámbito de la defensa.

Es decir, bajo la perspectiva de Brasil, el establecimiento de dicho Consejo favorecería la conformación de un mercado regional para su industria defensiva, como parte de la estrategia de desarrollo industrial puesta en marcha desde hace tiempo por ese país, y con mayor fuerza luego de la publicación en 2008 de su Estrategia Nacional de Defensa, la que señala que la estrategia nacional de defensa es inseparable de su estrategia de desarrollo.

Según destaca Nicolás Comini, al mismo tiempo que Brasil impulsaba el Consejo regional, paralelamente lanzaba un amplio proceso de reactivación y modernización de su complejo industrial de producción en el ámbito de la defensa, que ya había sido diagramado en el proyecto "Brasil 3 tiempos: 2007, 2015, 2022" y en el Programa de Aceleración del Crecimiento (2007), que fue acompañado por la aprobación de la Estrategia Nacional de Defensa, el Decreto de Reglamentación de la Ley de Movilización Nacional (2008) y la realización de los Ejercicios Frontera Sur; de manera paralela al reclamo brasileño por incrementar su producción de energía nuclear (Comini, 2010: 1718).

Específicamente, la Estrategia Nacional de Defensa, que fue anunciada por el Presidente Lula en Brasilia el año 2008, resultaba particularmente relevante, en tanto con ella "por primera vez Brasil tornaba pública su visión del mundo, sus percepciones de amenaza y desafíos, así como la organización, disposición y organización para afrontarlos" (Saint-Pierre, 2012: 135). El documento plantea

\footnotetext{
${ }^{64}$ Una visión crítica sobre esta visión "sudamericana" de la integración, bajo la perspectiva de México, puede verse en Luiselli (2010)
} 
la ampliación, modernización y reposición de las fuerzas militares, además de referirse a la industria de la defensa. De manera coherente con el férreo apoyo brasileño al Consejo de Defensa Suramericano, la estrategia, entre otras directrices, se propone estimular la integración sudamericana, no solo para contribuir a la defensa de Brasil, sino también para fomentar la cooperación militar regional y la integración de las bases industriales de defensa. Consecuentemente con estos lineamientos, en el marco del Consejo, Brasil junto a Argentina- lanzó la propuesta de fabricar aviones de entrenamiento y aviones no tripulados para la región, asuntos que fueron incluidos en el Plan de Acción del Consejo de Defensa del año 2012.

Al anunciar la nueva Estrategia Nacional de Defensa, el Presidente Lula explicó que la necesidad de fortalecer al sector defensa, se conecta con las nuevas responsabilidades de Brasil en el actual escenario internacional. La Estrategia busca enfrentar la tradicional crítica hacia la supuesta debilidad del sector defensa brasileño, considerando las aspiraciones globales de este país, especialmente en lo referido a sus aspiraciones de alcanzar un asiento permanente en el Consejo de Seguridad de Naciones Unidas. Asimismo, en el plano hemisférico, como señala Saint-Pierre, los esfuerzos estratégicos se concentraban en garantizar la autonomía del país frente a Estados Unidos, evitar caracterizar al continente americano como un espacio estratégico único y buscar la identidad estratégica de la región de América del Sur (Saint-Pierre, 2012: 135-136).

Desde luego, los argumentos anteriores no dejan de lado la posibilidad de que Brasil busque impulsar la integración regional y la consolidación del CDS con una sincera intención de fomentar la gobernanza, el multilateralismo, la estabilidad regional y la proyección de América del Sur en el mundo. Seguramente, un adecuado entendimiento de este apoyo requiere apreciar la validez y peso relativo de cada uno de estos elementos. De hecho, en tal sentido, Saint-Pierre señala que la citada Estrategia tiene el mérito de reconocer la inexistencia de enemigos y la indeterminación de las amenazas, trabajando en la substitución del concepto clásico de "hipótesis de guerra" por "hipótesis de empleo", de mayor coherencia con el compromiso constitucional de Brasil con la paz (Saint-Pierre, 2012: 156). 
ex Ministro de Defensa de Brasil, Nelson Jobim, ha señalado lo siguiente, respecto del motivo que guió a Brasil a impulsar el establecimiento del Consejo de Defensa Suramericano:

\begin{abstract}
"Al participar, efectivamente, de todos los foros regionales y subregionales en América del Sur, Brasil se presenta como el elemento inductor, al promover e incentivar las reuniones en el ámbito de dichos organismos...Brasil considera que tiene la responsabilidad de participar como elemento catalizador de las iniciativas de integración en América del Sur, buscando crear un ambiente de cooperación necesario para garantizar la estabilidad, la paz y una mayor seguridad para todos, en una clima de convivencia armoniosa con sus vecinos...Ese es el objetivo que motivó la propuesta de la creación del Consejo de Defensa Suramericano, en el ámbito de la UNASUR: un foro cooperativo, equilibrado y democrático, donde las decisiones se toman por consenso; un foro que respete las diversidades, las aspiraciones, los valores y las tradiciones de cada nación y, sobre todo, que sea capaz de adaptarse a las nuevas situaciones..." (En Ministerio de Defensa Nacional de Chile, 2009: 24-25).
\end{abstract}

Sin embargo, según sostienen María Regina Soares de Lima y Mónica Hirst (2007: 100-101), la expansión que últimamente se ha apreciado en la participación política de Brasil en las crisis regionales, junto con las crecientes actividades comerciales y de inversión con sus vecinos sudamericanos -sin olvidar el fuerte apoyo al Consejo de Defensa Suramericano- no han implicado un reconocimiento automático de su liderazgo regional, lo que se ha expresado en las diferencias entre los países en torno a un eventual apoyo para que Brasil ocupe un asiento permanente en el Consejo de Seguridad de Naciones Unidas.

Es decir, el entorno regional no ha sido particularmente entusiasta respecto del eventual liderazgo que pueda ejercer Brasil en materia de integración e inserción internacional de la región en la política y la economía globales. Según señala 
Andrés Malamud, la política exterior de este país no ha logrado traducir sus recursos estructurales e instrumentales en un efectivo liderazgo regional. $\mathrm{O}$ sea, los potenciales seguidores de Brasil no se han alineado con las principales metas de la diplomacia del gigante sudamericano, como es el caso de su pretensión por alcanzar un asiento permanente en el Consejo de Seguridad (Malamud, 2011). Según Malamud, el liderazgo de un Estado puede ser entendido como la capacidad de influenciar a los países seguidores (Malamud, 2011: 3). Es decir, hacer que estos adopten las metas y objetivos del Estado líder, como si fueran las suyas propias. Este concepto difiere de la hegemonía, en tanto ésta se entiende como la capacidad de un Estado poderoso (hegemón) para dictar políticas y lineamientos a otros Estados. Como señala Richard Higgot, el liderazgo no es lo mismo que la preponderancia económica y militar, más bien, tiene un carácter intelectual e inspiracional (En Malamud, 2011: 4). Es decir, es cercano a los atributos del denominado soft power, acuñado por Joseph Nye, que se refiere a la habilidad de atraer y cooptar a otros actores mediante de mecanismos consensuales, antes que a través de la fuerza física y la coerción (Nye, 2005).

Sin embargo, el liderazgo brasileño no cuenta con una aceptación unánime dentro de los países de la región, como lo expresa la competencia que plantean al respecto México y Argentina. De hecho, ambos países forman parte, en el marco de las negociaciones intergubernamentales sobre la reforma del Consejo de Seguridad de Naciones Unidas del grupo denominado "Unidos por el Consenso", que se opone a la incorporación de nuevos miembros permanentes a dicho órgano, como es justamente la pretensión de Brasil.

También cabría destacar la competencia por el liderazgo regional que planteó en su momento Venezuela en los tiempos de la administración de Hugo Chávez, con iniciativas que concitaron un fuerte apoyo entre ciertos países de la región, como fueron los casos de ALBA y PETROCARIBE.

En suma, según apunta Andrés Malamud, todavía ciertos países del entorno aprecian las estrategias de Brasil como meras incursiones hegemónicas, destinadas a favorecer los propios intereses, antes que como actividades iluminadas por un liderazgo basado en los intereses compartidos (Malamud, 
2011: 19). El excesivo pragmatismo de Brasil de apreciar a la región como un mero trampolín de su posicionamiento internacional ha dañado su eventual liderazgo regional. Asimismo, entre otras debilidades que debe enfrentar el gigante sudamericano, están las profundas desigualdades internas, la pobreza, la corrupción y los altos niveles de violencia y criminalidad, los cuales afectan de manera importante el soft power y el posicionamiento de este país a nivel regional e internacional.

Como una manera de apuntalar el posicionamiento regional de Brasil a nivel sudamericano, Fernando Henrique Cardoso organizaría la primera Cumbre Sudamericana, que se celebró en Brasilia en septiembre del año 2000, al mismo tiempo que impulsaba la integración física de la región, a través de la creación de la iniciativa IIRSA. Dicha cumbre dará lugar, bajo la presidencia de Lula Da Silva, que puso a la región en lugar prioritario de las labores de Itamaraty, a la Comunidad Sudamericana de Naciones, establecida en diciembre del año 2004 en el Cuzco, con el objeto de aglutinar los esfuerzos integradores de los países de la CAN y el MERCOSUR. Como se señaló anteriormente, esta Comunidad pasaría a denominarse UNASUR, a partir de la Cumbre de Isla Margarita del año 2007. En el marco de la UNASUR, Brasil sugirió la creación del Consejo de Defensa Suramericano como una manera de que los países de la región abordaran de manera autónoma sus necesidades de defensa, sin el concurso de otras potencias extrarregionales. Esta idea cobró particular fuerza tras la crisis suscitada entre Colombia y Ecuador en marzo de 2008.

Con su estrategia de posicionamiento regional, Brasil intenta promover consensos viables, incorporando los intereses de otros países y moderando los elementos más radicales del chavismo. En el marco de su estrategia global de país emergente, el Consejo de Defensa Suramericano responde a las pretensiones del gigante sudamericano, seguidas también por otros países de la región, de contar con un foro o mecanismo regional de seguridad cooperativa, en vez de la tradicional arquitectura hemisférica de seguridad, tan impugnada desde ciertos sectores de la región (Sanahuja y Verdes-Montenegro, 2014).

Bajo estos lineamientos es que el Presidente Lula Da Silva encomendó al Ministro Jobim la tarea de iniciar conversaciones con sus pares de América del Sur, con el 
objetivo de impulsar la creación, en el ámbito de la UNASUR, de un foro que reuniera a los titulares de las carteras de defensa de la región. Bajo la perspectiva de Brasil, el impulsar el Consejo otorgaría una mayor legitimidad a su pretensión de ocupar un asiento permanente en el Consejo de Seguridad de Naciones Unidas y permitiría a la región encarar los temas de defensa con una perspectiva regional, dejando a un lado la presencia norteamericana, tan involucrada con el proceso de seguridad colombiano. El impulso del Consejo de Defensa Suramericano por parte de Brasil, debe entenderse especialmente considerando la prioridad sudamericana asumida por la administración Lula. Según sostenía en 2009 el entonces Ministro de Defensa, Nelson Jobim,

"Al analizar las actuales directrices de la política exterior adoptadas por el gobierno brasileño, se observa que América del Sur está cada vez más presente como un área de interés nacional. La región ha pasado a ser una referencia para la búsqueda de acciones concretas, que gradualmente ganan espacio y relevancia en la agenda del país...Dentro de este alcance, a comienzos de 2008, recibí del Presidente Luís Inácio Lula Da Silva la tarea de iniciar negociaciones con autoridades gubernamentales de América del Sur, con el objeto de crear, en el ámbito de la Unión de Naciones Suramericanas (UNASUR), un foro que reuniera a los titulares de las carteras de defensa de todos los países de nuestra región" (Jobim, 2009: 19).

En lo relacionado particularmente con la creación del Consejo, el Ministro Jobim planteó que:

"La propuesta brasileña fue el resultado de las visitas que realicé personalmente a todos los Ministros de Defensa del subcontinente, de los cuales obtuve manifestaciones de simpatía y apoyo a la idea. Se buscaba, entonces, extender al ámbito de la 
defensa los avances ya logrados en otros sectores, consiguiendo el apoyo para una propuesta para la creación de un modelo en que prevalecieran las iniciativas de cooperación en el campo de la defensa, y en que también se hicieran presentes acciones que contemplaran incentivos a la consolidación de una base industrial de defensa que satisficiera las necesidades de los países integrantes" (En Ministerio de Defensa Nacional de Chile, 2009:19).

Por último, cabe destacar, que el impulso brasileño para la CDS no se planteó como una oposición frontal contra Estados Unidos. En tal sentido, Brasil ha procurado adoptar una postura moderada, bastante lejana a los fuertes ataques antiimperialistas proferidos desde Venezuela. Más bien, a nivel general, la política exterior de Brasil, contando con el férreo apoyo de su política de defensa, ha optado por una opción de convivencia con la potencia norteamericana, como lo expresa que, entre las primeras gestiones realizadas durante 2008 por Jobim en orden a explicar y conseguir apoyos para el CDS, estuviera una visita a Estados Unidos, ocasión en la cual se reunió con el Secretario de Defensa, Robert Gates, y con la Secretaria de Estado, Condoleeza Rice. Sobre este aspecto, Jobim señaló claramente que el CDS "no es contra nadie". ${ }^{65}$ A ello agregaba que "...en ningún momento se consideró la constitución de una alianza militar de defensa suramericana, en el sentido clásico, del tipo OTAN del Sur, u otro tipo de modelo que pueda, a priori, articular acciones en el plano operacional, como una Fuerza Suramericana de Paz" (En Ministerio de Defensa Nacional de Chile, 2009: 20). El protagonismo brasileño en el Consejo de Defensa va acompañado por un marcado predominio militar en la región, lo que ha sido fuente de suspicacias entre ciertos gobiernos del área, que han señalado que el Consejo se habría elaborado a la medida de Brasil, siendo enteramente dependiente de los lineamientos puestos en marcha por este país.

65 Véase la nota de prensa disponible en http://www.lostiempos.com/diario/actualidad/internacional/20090311/unasur-crea-elconsejo-de-defensa-suramericano_9457_15440.html Recuperado en octubre de 2015. 
Sin embargo, como se señaló anteriormente, en la práctica el Consejo se ha configurado en un instrumento afín a las necesidades de seguridad de la región en su conjunto, antes que constituirse como un instrumento de predominio brasileño. Ello ha sido el resultado de una notoria conducta de automoderación de Brasil, que va de la mano del interés de otros países por participar activamente del señalado órgano, como es el caso de Chile, Ecuador y Argentina.

En una entrevista realizada al encargado del seguimiento de esta materia en el Ministerio de Defensa de Brasil, el Gerente de la Sección del Consejo de Defensa Suramericano, Rubem Ribeiro Veloso, este planteó al respecto que el apoyo de Brasil al Consejo se ejerce de manera colectiva con los demás países de la región, donde "ningún país está por sobre otro, todos son iguales", en la búsqueda de "integrar y cooperar para avanzar en la confianza mutua, atendidos ciertos conflictos bilaterales". 66

Junto con lo anterior, Ribeiro Veloso enfatizó que el Consejo representa un foro de diálogo y coordinación, no exclusivo con otras instancias regionales, en tanto "busca complementar el trabajo que realiza el sistema hemisférico". A su juicio, entre los temas prioritarios de Brasil en el Consejo, junto con la industria de la defensa, está el ámbito de la formación y capacitación, donde destaca la celebración anual del Curso Avanzado de Defensa Sudamericano (CADSUL), organizado por Brasil, en el cual se pretende aportar al desarrollo de un pensamiento sudamericano en materia de defensa, "con base en la cooperación e integración regionales", mediante la formación de civiles y militares que se desenvuelven en el área de defensa en los países miembros de la UNASUR. ${ }^{67} \mathrm{La}$ moderación brasileña intenta matizar las precauciones que se han planteado en la región, ante la importante asimetría que existe en el ámbito estratégico sudamericano, con una clara superioridad militar del país carioca.

Pese a las diferencias en materia de gastos, cabe señalar que tradicionalmente Brasil ha sido calificado como un país de carácter pacifista respecto de su entorno, lo que se explica especialmente dada su condición de país satisfecho en términos territoriales. Según Susanne Gratius (2007: 27), por “...la actuación política en su

\footnotetext{
${ }^{66}$ Entrevista realizada el 14 de octubre de 2016, en Washington D.C.

${ }^{67}$ A este respecto, véase http://www.esg.br/index.php/br/defesa-sul-americano-cad-sul
} 
entorno geográfico, Brasil ha podido elevar su prestigio internacional y es percibido, tanto por EE.UU, como por algunos países latinoamericanos, como factor estabilizador en la región".

En la misma línea, João Bertonha plantea que el tradicional pacifismo brasileño ha contribuido a su soft power -en los términos planteados por Joseph Nye-, siendo apreciado en el ámbito externo por su desempeño diplomático y capacidad negociadora. Junto con lo anterior, este autor destaca que, entre los países del BRICS, Brasil es el único que no posee armas nucleares y que mantiene una menor capacidad militar (Bertonha, 2010). Ello se encuentra contextualizado en una región caracterizada por la paz y la práctica ausencia de conflictos bélicos, donde predomina una lógica negociadora y no confrontacional, un bajo gasto en el ámbito militar, y donde no existen rivales estratégicos relevantes para el coloso sudamericano. Esta condición de paz en la región, explicaría en parte el que las fuerzas armadas de América del Sur se hayan concentrado en tareas relacionadas con las operaciones de paz de Naciones Unidas, asistencia social y ayuda humanitaria, antes que a las labores tradicionales del conflicto westfaliano.

Sin embargo, considerando la expansión de las ambiciones internacionales de Brasil, como el alcanzar un asiento permanente en el Consejo de Seguridad, el potenciar su acción en el seno del BRICS y el G20, así como impulsar su liderazgo regional en América del Sur, desde este país se ha planteado la necesidad de reforzar sus fuerzas y capacidades militares, frente al tradicional pacifismo que habría exhibido en su accionar exterior (Bertonha, 2010).

Consecuentemente con lo anterior, al igual que otros autores, Bertonha ha sugerido que Brasil debe incrementar sus fuerzas militares a fin de hacerlas coherentes con el alcance de tales objetivos. Según este autor, por su tamaño relativo y por constituirse como el país más poderoso de la región, Brasil debe asumir una posición de liderazgo en la integración regional, como condición básica de la proyección internacional de América del Sur y de su competitividad en las corrientes económicas y políticas globales. Y de manera coherente con ello, a su juicio, este país debería aumentar su capacidad militar para mantener una posición autónoma e independiente frente los poderes mundiales, que igualmente apoye su soft power y aumente su credibilidad internacional. Según Bertonha, en 
último término, sin un efectivo hard power, los vínculos culturales y la diplomacia, propios del soft power, podrían volverse menos creíbles y relevantes para este país.

Pese a lo anterior, tal como se señaló anteriormente, aún cuando Brasil ha manifestado tradicionalmente un comportamiento exterior pacífico, no obstante ello, de todos modos se presenta en la actualidad como el país de la región más poderoso en términos de su poderío militar. Por lo demás, incrementar su hard

power podría eventualmente dañar su soft power, generando resistencias en su entorno y, en último caso, afectando sus posibilidades de constituirse como un líder en la región.

\section{b) El papel de Chile}

En la década de los noventa, la política exterior de Chile asumió la tarea de reinsertar al país en las corrientes globales, luego de años de aislamiento durante el régimen militar. Según señala Luis Maira, durante 16 años, más de 95 países condenaron a Chile en la Asamblea General de Naciones Unidas, por los atentados contra los derechos humanos. A ello se sumó el rompimiento o congelamiento de relaciones diplomáticas con muchos Estados, como fue el caso de México, Argelia, Italia, Francia y España (Maira, 2007: 164).

En este marco, junto con el regreso a la democracia Chile debió asumir la tarea de la reinserción en la comunidad internacional. Al poco tiempo de asumir como Presidente Patricio Aylwin, se retomaron las relaciones con aquellos países con los cuales habían sido suspendidas y se regularizó la participación chilena en diversas instituciones multilaterales, presentándose al país como un ejemplo de recuperación democrática. Este proceso se enmarcó en los profundos cambios que vivía el mundo, relacionados con la caída del Muro de Berlín y el fin de la Guerra Fría, y el consecuente dinamismo que adquirió el proceso de globalización. En suma, se enfrentaba un profundo contexto de transición interna e internacional. Según sostienen Myriam Colacrai y María Elena Lorenzini, con la vuelta de la democracia y el proceso de reinserción internacional, "Chile se define como un país mediano, no periférico, integrado al mundo y a la región, exitoso 
económicamente y estable desde el punto de vista político-institucional" (Colacrai y Lorenzini, 2005: 47). De este modo, el país pasaba de tener una política exterior reactiva y defensiva durante el régimen militar, a una política que apuntaba a una inserción global activa e integral, sustentada en su régimen democrático, la promoción de los derechos humanos y la apertura comercial.

De tal modo, durante la administración de Patricio Aylwin, Chile transitó desde un severo aislamiento internacional a una paulatina pero creciente inserción en las corrientes políticas y económicas internacionales, que se enmarcaban en la interdependencia global que, luego del fin de la Guerra Fría, cobró gran dinamismo en distintas partes del mundo. Este proceso permitió incrementar las conexiones con distintas áreas y regiones, que hasta el presente se constituyen como mercados fundamentales para el crecimiento económico del país. De tal manera, haciendo una breve síntesis, y siguiendo a Iván Witker (2005: 53), es posible plantear que la política exterior chilena de los noventa estuvo marcada por los objetivos prioritarios de mejoramiento de las relaciones vecinales, retorno activo a los foros multilaterales y la institucionalización de los vínculos comerciales. Ello se realizó mediante una política exterior que promovía un multilateralismo inclusivo y no selectivo, una diplomacia con un tinte altamente comercial, aunando nociones como las cláusulas democráticas y el Regionalismo Abierto.

Con esta base, el país ha participado, desde los noventa, con diversos grados de profundidad en varias instancias regionales, como es el caso del MERCOSUR, la CAN y la UNASUR. También cabe destacar la contribución de Chile en el proceso de convergencia del Grupo de Río y la Cumbre de América Latina y el Caribe (CALC), que decantó en la Comunidad de Estados Latinoamericanos y Caribeños (CELAC), presidida por este país entre diciembre de 2011 y enero de 2013.

Haciendo un poco de historia, es necesario señalar que los impulsos de apoyo a la integración regional fueron particularmente visibles durante la década de los sesenta, cuando el país fue un activo y voluntarista promotor del regionalismo, lo que se plasmó en el protagonismo chileno en la constitución del Pacto Andino. A ello contribuyó el fuerte influjo de las ideas de la CEPAL, con sede en Santiago, que concebían en ese entonces a la integración como un mecanismo defensivo 
frente al capitalismo internacional que, al tiempo que favorecía la ampliación de los mercados nacionales, proyectaba un esquema de Industrialización por Sustitución de Importaciones (ISI) a la escala regional.

Estas tendencias cambiaron desde 1973, cuando el golpe militar inauguró un régimen contrario a toda tendencia latinoamericanista. La integración regional pasó a percibirse como un asunto propio de la izquierda, bajo el prisma de la Doctrina de Seguridad Nacional. Ello se expresó, por ejemplo, en el retiro del país del Pacto Andino. La integración regional también parecía contrarrevolucionaria en relación con el intenso proceso de liberalización económica que se puso en marcha en el país en ese período.

Como se señaló más arriba, este enfoque nuevamente cambió con la vuelta de la democracia en Chile, que trajo consigo un ingente proceso de reinserción internacional y regional. Aunque esta vez la mirada sobre la integración regional fue más pragmática y menos voluntarista que en los años sesenta, en virtud del principio del Regionalismo Abierto y de la relevancia del comercio exterior para el modelo de desarrollo chileno. El regionalismo abierto asumido en el campo de la política exterior suponía afianzar las relaciones con América Latina, pero ello no era óbice para incrementar igualmente las relaciones con otras regiones de alta relevancia, como América del Norte, Asia Pacífico y Europa.

Según consigna el libro Perspectivas, Proyecciones y Desafíos de la Política Exterior de Chile, del Ministerio de Relaciones Exteriores, entre los intereses prioritarios de la política exterior está el contribuir al fortalecimiento de la integración regional. En esta línea, el texto sostiene que:

"La integración de Chile a América Latina se ha constituido en uno de los elementos más importantes de nuestra política exterior, lo cual se refleja en el significativo número de proyectos que, en diferentes áreas, se orientan a acercarnos a los países de la región bajo un marco de un mutuo respeto y entendimiento" (Ministerio de Relaciones Exteriores, 2010: 21). 
En el mismo sentido, el ex Canciller Mariano Fernández ha sostenido que "La Política Exterior de Chile tiene como centro de gravedad la promoción de una identidad común en América Latina, región en la cual compartimos una historia, culturas, intereses y objetivos" (Fernández, 2010: 48). Bajo un punto de vista pragmático, cabe señalar también que el apoyo chileno hacia la integración regional ha ido de la mano de la idea de plantear a Chile como un puente entre las economías asiáticas situadas en la cuenca del Pacífico y las economías sudamericanas (véase Furche, 2010: 20).

Bajo los supuestos del Regionalismo Abierto, Chile se asoció al MERCOSUR en la reunión de Jefes de Estado, celebrado en San Luis en 1995. Asimismo, es miembro asociado de la CAN desde el año 2006, habiendo sido uno de los principales impulsores del Pacto Andino, establecido en 1969. La calidad sólo de miembro asociado a estas iniciativas (es decir, no como miembro pleno), se relaciona fundamentalmente con la diferencia de las estructuras arancelarias entre Chile y tales bloques. Como señala Luis Maira, la entrada plena de Chile al MERCOSUR y la CAN obligaría a dos situaciones que no parecen viables: "que los restantes países sudamericanos rebajaran sus aranceles o que Chile los subiera para alcanzar un punto de nivelación, dadas las exigencias de un Arancel Externo Común" (Maira, 2007: 176). Esta idea moderada y pragmática sobre la integración regional es la que trasunta el siguiente texto de Mariano Fernández:

"La Política Exterior de Chile tiene como centro de gravedad la promoción de una identidad común en América Latina, región con la cual compartimos una historia, cultura, intereses y objetivos. Adicionalmente, impulsamos la mayor integración posible $y$, parafraseando a un ex Presidente de Chile, lo hacemos en la medida de lo posible" (Fernández, 2010: 48).

En la misma línea, en una columna aparecida en el diario La Tercera, titulada "América Latina: una prioridad", el Canciller Heraldo Muñoz señaló lo siguiente: 
"Chile ejerce un liderazgo mesurado que trasciende su peso demográfico o económico. Somos considerados un país serio, que propone ideas constructivas y ajustadas a lo que se requiere. Un ex Presidente brasileño solía decir que Chile es una potencia conceptual...La presencia regional de nuestro país se ha incrementado desde que la Presidenta Bachelet decidió reforzar el acompañamiento chileno de las conversaciones de paz entre las FARC y el gobierno de Colombia. Nos enorgullece participar en la búsqueda de una región más pacífica y segura para todos..."68

De tal modo, si bien existen variados y a veces contradictorios procesos de integración en la región, las tendencias que ha seguido el país en la materia han llevado a Carlos Portales a sostener que "la política latinoamericana de Chile ha contribuido a limar asperezas entre los países de los mecanismos en que participa y a buscar consenso para avanzar, hasta donde sea posible alcanzarlos" (Portales, 2011, p. 178). Esta posición pragmática y moderada de Chile ante la integración regional, responde a su interés por incrementar su estatura estratégica, autonomía e influencia en el multilateralismo internacional, sin perjudicar sus intereses nacionales en virtud de ciertos voluntarismos.

No obstante, la moderación y pragmatismo exhibido por Chile en sus relaciones con la región, en el marco del Regionalismo Abierto, le han valido una serie de críticas desde diversos sectores -tanto a nivel nacional como internacional-, que cuestionan el verdadero compromiso chileno hacia la integración, señalando que el país habría optado por priorizar acuerdos comerciales con actores extrarregionales, antes que fortalecer sus relaciones con los países del entorno. En una entrevista realizada al profesor Máximo Quitral, de la Universidad Arturo Prat, este fue claro en sostener que:

\footnotetext{
${ }^{68} \mathrm{La}$ columna se encuentra disponible en http://www.latercera.com/noticia/opinion/ideas-ydebates/2015/08/895-643517-9-america-latina-una-prioridad.shtml Recuperado en agosto de 2015.
} 
“...la región no es un tema prioritario para Chile, que ha manifestado una visión distante hacia el entorno. Más bien, se ha focalizado en llegar a acuerdos comerciales con potencias desarrolladas, que le permitan situarse en el mundo...este es un tema que se ha dado en el tiempo, ya desde los noventa la reinserción internacional de Chile optó por los acuerdos extrarregionales antes que América Latina, dando prioridad al comercio por sobre la política." ${ }^{\text {"9 }}$

La misma institucionalidad del Ministerio de Relaciones Exteriores de Chile pareciera dar razón a estas críticas, en tanto esta Secretaría de Estado carece todavía de una estructura fuerte para el adecuado seguimiento del tema de la integración regional. A diferencia de otras Cancillerías, como es el caso de Argentina, Brasil o Ecuador, que cuentan con reparticiones de alto perfil encargadas del seguimiento de esta temática, en Chile es sólo durante el segundo gobierno de Michelle Bachelet cuando se crea la Dirección de Integración Regional Multilateral. Anteriormente el tema estaba disperso en varias unidades del Ministerio, sin un seguimiento especializado y coherente con la declarada prioridad regional de la política exterior. Ante lo anterior, Jenne y Briones señalan que habría una brecha notable respecto de las tendencias de la política exterior chilena hacia la integración regional, por cuanto, "mientras que la retórica de los actores promueve avances en los procesos regionales, los hechos muestran resultados e instituciones mucho más débiles de lo que esa retórica sustenta" (Jenne y Briones, 2018: 9).

No obstante, y pese a la moderación demostrada al respecto, como un país con pocos recursos de poder en su sentido más tradicional y con un pequeño tamaño relativo, la participación de Chile en instancias de integración regional se aprecia como una manera pragmática de incrementar su peso y capacidad de incidencia en las decisiones mundiales, procurando resguardar sus intereses nacionales muchos de ellos relacionados con el mantenimiento de la autonomía en materia

${ }^{69}$ Entrevista personal concedida el 27 de octubre de 2015. 
comercial- más allá de los voluntarismos. Este es también el tenor bajo el cual debe entenderse la participación chilena en el Consejo de Defensa Suramericano. Últimamente, el segundo gobierno de la Presidenta Michelle Bachelet planteó, en materia de integración regional, la idea de la Convergencia en la Diversidad, considerando la proliferación de iniciativas que se aprecian en la región, poniendo un especial énfasis en la necesidad de avanzar en el acercamiento entre la Alianza del Pacífico y el MERCOSUR. En los inicios de esta administración, el Ministro Muñoz, a través de la columna "Convergencia en la diversidad: la nueva política latinoamericana de Chile", aparecida en el diario El País de España, planteó que:

"Chile valora la Alianza del Pacífico como esquema de integración económica y plataforma comercial de proyección colectiva a la región de Asia Pacífico; pero no compartirá pretensión alguna de concebir dicha Alianza como un bloque ideológico excluyente o antagónico con otros proyectos de integración...Convergencia en la diversidad es la política que Chile buscará promover en América Latina. Es una opción que combina realismo y voluntad política de avanzar hacia una región más integrada y autónoma". ${ }^{70}$

A fines de mayo de 2014, con ocasión de su participación en la XI Reunión de Cancilleres de la Alianza del Pacífico celebrada en México, el Ministro Muñoz, al momento de conceder una entrevista al periodista Andrés Oppenheimer, volvió a referirse a su propuesta de la Convergencia en la Diversidad, planteando la necesidad de superar la supuesta fractura regional entre la vertiente atlántica y pacífica. En concordancia con lo anterior, en la declaración final de la reunión de la Alianza del Pacífico, a propuesta de Chile, se recogió la idea de ampliar el diálogo con los países del MERCOSUR. Como resultado de la propuesta chilena, el 1 de noviembre del mismo año se celebró en Cartagena de Indias una reunión conjunta

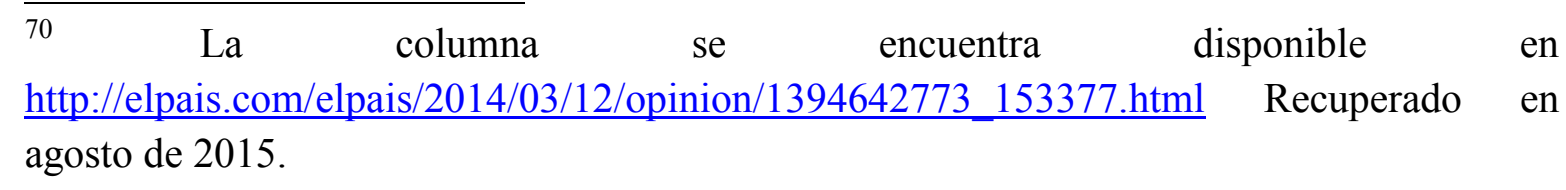


de ambos bloques, con miras a avanzar en la armonización de dichas instancias. Al respecto, dando muestras de moderación, el Canciller Muñoz señaló que "hay que ser gradual, pragmático y complementario. No se trata de estimular una fusión de los bloques. No está en la agenda" (El Mercurio, 2 noviembre 2014).

Finalmente, en el plano de la prioridad regional declarada por la política exterior de Chile, la participación en la UNASUR se encuentra en un lugar preeminente, atendida su relevancia como instancia eminentemente política que favorece la gobernanza regional y la inserción internacional de América del Sur en su conjunto, sin impugnar los lineamientos chilenos en materia de autonomía comercial. La mirada moderada, abierta y pragmática de Chile sobre la integración, que la aprecia como una estrategia activa de inserción en las corrientes globales, como se verá en los siguientes acápites, es la que guía consecuentemente la participación del país en el Consejo de Defensa Suramericano, en el marco de la prioridad regional declarada por la política exterior.

\section{El papel de Chile en la constitución del Consejo de Defensa Suramericano}

La reinserción internacional de Chile durante los noventa implicó un paulatino proceso de actualización de la política exterior, la que encontró en la política de defensa un importante elemento de apoyo a su proyección. La primera apuntaría al posicionamiento exterior de Chile en sus aspectos políticos y económicos, mientras la segunda se orientaría a los aspectos estratégicos de seguridad. Siendo así, la política de defensa pasó a considerarse como un asunto relevante de la reinserción internacional y de la consolidación democrática.

La interdependencia global en los campos político, económico y social en que se vio envuelto Chile desde los noventa, junto al proceso de transición democrática que se desarrollaba, tuvo diversos efectos en la vida nacional. En el ámbito particular de la defensa, se configuró como una oportunidad para repensar el rol de los militares en el marco del régimen democrático. Es decir, luego de la participación directa de las fuerzas armadas en la conducción política, el paulatino restablecimiento de la democracia implicó el desafío de limitar la influencia de este sector en temas relativos a la contingencia política, así como reestructurar y 
redefinir sus funciones (Álvarez, 2004). En la práctica, actualmente las fuerzas armadas de Chile han pasado a cumplir un rol fundamental en apoyo a la política exterior, lo que ha sido particularmente visible en la participación nacional en operaciones de paz, bajo mandato de Naciones Unidas.

En el campo de las relaciones civiles-militares, durante la primera presidencia de Michelle Bachelet, con la elaboración del Libro de la Defensa Nacional de 2010, puede ya plantearse una etapa de normalidad institucional, que se expresa, entre otros aspectos, en una positiva percepción de los militares por la ciudadanía. A ello ha contribuido especialmente la positiva valoración respecto de las actividades que han realizado los militares durante los diversos eventos de desastres naturales que han azotado el país. Según señala Rodrigo Atria, en una democracia consolidada las relaciones civiles-militares se enmarcan dentro de las siguientes reglas: una cadena de mando claramente definida desde la autoridad civil a las fuerzas armadas; el cumplimiento de la decisión del empleo de la fuerza en manos civiles; y la activa ejecución del papel reservado al liderazgo civil en la función defensa del Estado, para que las reglas anteriores no se reduzcan a la mera posesión de una autoridad formal (Atria, 2009: 15).

Actualmente puede sostenerse que, pese a los obstáculos y fricciones (véase Fuentes, 2002), Chile ha ingresado a una fase de consolidación democrática, es decir, aquella en la cual existe una supremacía civil y donde los militares pierden la prerrogativa de vetar la acción de los gobernantes democráticamente electos. ${ }^{71}$ El hecho trascendental en tal sentido, fue la promulgación en febrero de 2010 de la Ley Orgánica del Ministerio de Defensa Nacional de Chile $N^{\circ} 20.424$, que viene a consolidar la conducción política de la defensa.

El ex Ministro de Defensa chileno, Jorge Burgos, plantea que el país "posee una estructura jurídica política con un claro control civil sobre las fuerzas armadas", donde ha cumplido un importante papel la mencionada Ley $\mathrm{N}^{\circ} 20.424$, que establece una nueva estructura de la mencionada Secretaría de Estado, que cuenta con una Subsecretaría de Defensa, que opera como órgano asesor de

\footnotetext{
${ }^{71}$ En el mismo tenor, Thomas Bruneau plantea que la consolidación democrática involucra un sistema donde ningún área de gobierno puede ser excluida del control de los líderes civiles democráticamente electos (2005: 120).
} 
primer nivel para el Ministro; una Subsecretaría para las Fuerzas Armadas; y un Estado Mayor Conjunto, con un papel relevante en tiempos de paz, pero con mayores atribuciones en tiempos de excepción (Burgos, 2014: 165).

Tales avances suponen un cambio trascendental en los postulados de la antigua Doctrina de Seguridad Nacional, impulsada luego de la Segunda Guerra Mundial desde Estados Unidos, la que suponía que los Estados latinoamericanos debían enfrentar la amenaza del comunismo, en el contexto de una "Tercera Guerra Mundial", que se enfrentaba en el ámbito interno de los países occidentales. Bajo este enfoque, era necesario asumir un tipo de estrategia que permitiera enfrentar al "enemigo interno", conformado por aquellos partidos y fuerzas hostiles a Estados Unidos. Ello serviría de base para el impulso a la participación de los militares en la conducción política de los países (Maira, 2007). Como señala Margaret Crahan, esta doctrina se sustentaba en una concepción geopolítica decimonónica, que entendía a los Estados como organismos biológicos en una continua lucha por expandir su espacio vital, cuya última expresión era la guerra. A ello se unía un fuerte antimarxismo; un pensamiento católico conservador, heredero del pensamiento integrista, que a su vez derivaba de los movimientos Opus Dei y Acción Francesa; y un desencanto hacia la democracia y los partidos políticos (Crahan, 1982).

Bajo estos preceptos se percibía a los países vecinos como potenciales amenazas a la seguridad, lo que en Chile se materializaría en situaciones extremas de tensión con Perú y Argentina. Con este último país se estuvo al borde del enfrentamiento bélico en 1978.

Sin embargo, estos anacrónicos supuestos sobre la seguridad nacional y la disuasión dieron paso a nociones más modernas, que han permitido adecuar paulatinamente la política de defensa, que ha avanzado de manera firme en sus aspectos cooperativos, con una política exterior de corte fuertemente internacionalista.

De tal manera, los avances señalados en materia de control civil en el sector defensa, permiten aseverar que los postulados sobre la seguridad nacional antes enunciados, propios del contexto de la Guerra Fría, han perdido toda vigencia en el país. En Chile, es posible sostener que, en el ámbito de la defensa, se ha 
avanzado de manera paulatina pero creciente en la denominada "gobernabilidad democrática de la defensa" (véase Flisfisch y Robledo, 2012). Del mismo modo, como se ha señalado antes, se ha comenzado a valorar la dimensión internacional de la defensa, como soporte fundamental de la política exterior.

En este orden de ideas, cabe señalar que el Ministerio de Relaciones Exteriores ha cumplido, con el apoyo del Ministerio de Defensa, un relevane rol para coordinar la participación del país en variadas instancias multilaterales relacionadas con las materias de paz y seguridad internacionales. En la práctica, por ejemplo, Chile ha estado fuertemente comprometido con las operaciones de paz, particularmente con la MINUSTAH (manteniendo el apoyo a la sucesora Misión de Apoyo para la Justicia en Haití, MINUJUSTH), estando actualmente las discusiones enfocadas en la manera en que Chile mantendrá su participación en operaciones en el continente africano, ya sea en misiones de Naciones Unidas o bajo el marco de la Unión Europea, entidad con la cual el país firmó un Acuerdo de Gestión de Crisis en 2014. Desde luego, ello implicará un relevante desafío para las fuerzas armadas en materia de preparación y despliegue, entre otros. También, el país ha apoyado desde sus orígenes a la Comisión de Consolidación de la Paz, creada en diciembre del año 2005 como un órgano subsidiario tanto de la Asamblea General y del Consejo de Seguridad de Naciones Unidas, con el objeto de fortalecer las tareas de reconstrucción de países en situación de postconflicto.

Además, cabe señalar que el país ha sido pionero en su apoyo al concepto de la seguridad humana, formando parte de la Red de Seguridad Humana, así como respecto de la conceptualización sobre la Responsabilidad de Proteger (Riquelme, 2014), siendo igualmente un diligente participante en los distintos foros y mecanismos multilaterales sobre asuntos humanitarios, desarme y no proliferación, entre otros. Por último, cabe señalar que el prestigio internacional de Chile en tales materias, desde la década de los noventa, lo ha llevado a ser parte en tres ocasiones del Consejo de Seguridad de Naciones Unidas, en los períodos 1995-1996, 2003-2004 y 2014-2015. En los foros relacionados con la esfera de la defensa a nivel hemisférico y regional, Chile ha sido activo en instancias como la Comisión de Seguridad Hemisférica de la OEA, la JID, las Conferencias de 
Ministros de Defensa de las Américas y, desde luego, el Consejo de Defensa Suramericano, entre otros (Riquelme y Rosso, 2014).

Respecto del Consejo de Defensa Suramericano en particular, cabe sostener que la participación nacional en este foro ha representado una sección de relevancia de la declarada prioridad latinoamericana de la política exterior chilena. La participación de Chile en el Consejo es la manifestación del trabajo mancomunado entre la Cancillería y el Ministerio de Defensa Nacional en torno a un tema de alta trascendencia para la actuación exterior de Chile, como es la prioridad regional, con el objeto final de incrementar la estatura estratégica, la autonomía y la proyección internacional del país. Sin descuidar la vocación global del país, las labores en dicho esquema sudamericano dan cuenta del propósito chileno de inserción a nivel internacional, tanto en lo político como en lo comercial, bajo una perspectiva regional, tal cual lo demuestra la siguiente aseveración, que aparece en un documento preparado por la Cancillería de Chile:

"Aunque la Política Exterior en materia de Seguridad Internacional tiene vocación y despliegue globales, ella debe promover y respaldar vigorosamente los instrumentos, mecanismos y foros regionales y subregionales de seguridad: el aporte de Chile a la Paz y la Seguridad Internacional se hace desde nuestra región... Chile debe mantener su compromiso con el Consejo de Defensa Suramericano de UNASUR, fortaleciendo su actividad como un mecanismo promotor de diálogo, transparencia e información entre los países de la región" (Ministerio de Relaciones Exteriores de Chile, 2018: 63).

En un contexto internacional marcado por el fin de la Guerra Fría y la consecuente realineación del poder global -donde se aprecian evidentes tendencias hacia la integración regional y la generación de bloques-, bajo el prisma chileno, el Consejo es síntoma de un progresivo proceso de convergencia en América del Sur, donde se ha planteado una paulatina pérdida de vigencia de las tradicionales nociones sobre la seguridad nacional, perdiendo fuerza las clásicas hipótesis de conflicto, 
que percibían como enemigos a los países vecinos. Ello ha implicado comenzar a asumir la cooperación como un elemento de preeminencia en la defensa de los países. En una entrevista realizada al Director de Seguridad Internacional y Humana de la Cancillería chilena, Ministro Consejero Julio Bravo, este señalaba en tal sentido que:

"UNASUR es un ámbito de acción prioritario para nuestro país. Y en esta instancia el CDS representa un mecanismo importante de seguridad cooperativa, que aúna las distintas visiones que existen en la región en temas de defensa. El CDS expresa la idea de la convergencia en la diversidad". ${ }^{72}$

El proceso de convergencia y cooperación ha sido particularmente visible en las relaciones entre Chile y Argentina, proceso al cual se ha sumado últimamente Perú, país con el cual el 28 de junio de 2017 se retomó el Mecanismo 2+2, que se reúne a nivel de Ministros de Relaciones Exteriores y de Defensa, a fin de fortalecer la cooperación bilateral en defensa. Distinta es la situación de Bolivia, donde aún perviven desconfianzas, pero también es cierto que las diferencias se han canalizado por mecanismos jurídicos antes que a través del uso o amenaza del uso de la fuerza. Es decir, las relaciones entre Chile y Bolivia siguen siendo competitivas, dando lugar a un relacionamiento que se ha calificado desde el ámbito militar como de "normalidad con controversia", pero estas dificultades no han supuesto el uso del mecanismo de la guerra para resolver las diferencias. De hecho, en el plano operativo, en 2017 se han retomado las sesiones del Comité de Frontera e Integración entre ambos países, reuniéndose en dos ocasiones: en julio, en Santa Cruz de la Sierra, y en octubre, en la ciudad de Arica.

En este marco de replanteamiento de las clásicas hipótesis de conflicto, la vinculación entre la política exterior y la política de defensa ha sido fundamental para su mutua potenciación, pues las actividades que desarrollan las fuerzas armadas en materia de contribución a la paz y seguridad internacionales tienen directa relación con los objetivos nacionales y las prioridades que asigna la política

${ }^{72}$ Entrevista personal concedida el 19 de octubre de 2015. 
exterior en torno a la inserción internacional de Chile, con una perspectiva preferente hacia la región de América Latina. Sobre la base de estos renovados enfoques en materia de política exterior y de defensa, de la mano de Brasil, Chile fue uno de los principales impulsores del Consejo de Defensa Suramericano.

Chile ejerció la Presidencia Pro Témpore de la UNASUR entre el 23 de mayo de 2008 y el 10 de agosto de 2009. Según plantea el ex Subsecretario de Relaciones Exteriores de Chile, Ángel Flisfisch, los principios que rigen esta organización son coincidentes con los que inspiran la política exterior chilena: "irrestricto respeto de la soberanía, integridad e inviolabilidad territorial de los Estados, cooperación, búsqueda y consolidación de la paz, multilateralismo, gradualidad, lucha contra la pobreza y la exclusión, participación ciudadana" (Flisfisch, 2010: 60). Durante su gestión, Chile procuró que la organización avanzara en su consolidación, promoviendo la aprobación de su Tratado Constitutivo e impulsando el establecimiento de diversos consejos sectoriales y grupos de trabajo.

Durante la Presidencia chilena, y una vez conocida la decisión de los mandatarios de los países de la UNASUR respecto de crear un Grupo de Trabajo para definir los términos de funcionamiento de un Consejo de Defensa a nivel sudamericano, el Gobierno de Chile se planteó la tarea de organizar el trabajo. La creación del Consejo bajo la Presidencia chilena, como una instancia de consulta y coordinación en el ámbito de la defensa, representó un hito en materia de cooperación regional.

Para este fin se estableció una Presidencia Pro Témpore del Grupo de Trabajo, que recayó en Gonzalo García Pino, entonces Subsecretario de Guerra del Ministerio de Defensa Nacional. De este modo, surgió un equipo de trabajo interagencial, compuesto por funcionarios de la Subsecretaría de Guerra y del gabinete del Ministro de Defensa, así como del Ministerio de Relaciones Exteriores -particularmente de las Direcciones de Planificación, Seguridad Internacional y Protocolo (Ministerio de Defensa Nacional, 2009: 67).

Según señalaba en 2009 el entonces Ministro de Defensa Nacional de Chile, Francisco Vidal: 
“... la creación del Consejo de Defensa es un hito transcendental, pues satisface un antiguo anhelo regional por contar con un espacio de encuentro que proyecte una perspectiva común y orientada hacia el futuro sobre nuestros desafíos en materia de Defensa...Estos propósitos comunes, impensables hace algunos años, son posibles hoy gracias a la trayectoria de democratización de nuestras naciones, donde los grandes lineamientos de la Defensa emanan de la autoridad investida por los ciudadanos, la política de Defensa se entiende como una política de Estado y el poder civil convive en armonía con las Fuerzas Armadas" (En Ministerio de Defensa Nacional de Chile, 2009: 15-16).

Desde Chile, la constitución del Consejo se inscribe en un esfuerzo mayor, que pretende contribuir a la inserción internacional de América del Sur en el contexto cada vez más multipolar que se aprecia en el mundo. Ello va de la mano de un sostenido apoyo del país al multilateralismo, el cual pasa a constituirse como un complejo mecanismo de relacionamiento internacional, que promueve reglas claras y disciplinas transparentes, permitiendo, en consecuencia, otorgar oportunidades de participación a todos los actores.

De este modo, desde la perspectiva de Chile, sólo actuando de manera coordinada, la región puede tener una mayor incidencia en los procesos internacionales de toma de decisiones en materia de paz y seguridad, aportando desde su propia visión desde el mundo del Sur. El rol que pueda cumplir América del Sur resulta especialmente relevante, considerando su situación como una de las zonas más pacíficas del mundo, desde el punto de vista del conflicto interestatal, libre de armas de destrucción masiva y con el menor gasto en armamentos, a lo que se agrega el predominio, si bien con importantes desafíos, de regímenes de gobiernos democráticos -donde los militares están sujetos a las autoridades civiles-, y donde gran parte de los países participan de manera destacada en operaciones de paz. En suma, para Chile, la paz podría representar una "exportación no tradicional" de la región en las áreas más conflictivas del mundo. 
Junto con lo antes reseñado, se debe señalar que el país, al momento en que se analizaban las características que tendría el nuevo organismo regional, planteó, y así lo ha seguido haciendo, que este se constituyera como un foro exclusivamente defensivo, sin abarcar áreas vinculadas con la seguridad pública. $O$ sea, que correspondía a un Consejo de Defensa y no a un Consejo sobre temas de seguridad.

Asimismo, Chile ha promovido igualmente que el Consejo se mantenga como un foro flexible de diálogo estratégico, que canalice las iniciativas de cooperación bilateral y multilateral que se dan en la región en temas de defensa, sin pretender, hasta el momento, avanzar hacia la constitución de una alianza militar en contra de algún país en particular, como Estados Unidos. Esta idea queda clara en la siguiente aseveración de Gonzalo García:

"EI CDS se inscribe dentro de los mecanismos propios de la seguridad cooperativa. Por lo tanto, se aparta de la dimensión operativa que podría sugerir una alianza de naturaleza militar abarcadora de una política regional propiamente tal" (En Ministerio de Defensa Nacional de Chile, 2009: 38).

\section{Participación y prioridades de Chile en el Consejo de Defensa Suramericano}

Siendo la participación en el Consejo uno de los elementos principales para dar contenido y forma a la prioridad regional declarada por la política exterior de Chile, así como a una política de defensa que paulatinamente avanza en su carácter cooperativo, el país otorga una especial relevancia a dicho organismo regional, bajo el prisma de su políticas exterior y defensa, en tanto se constituye como el primordial foro de diálogo político en temas de defensa en la región.

El Consejo representa una instancia valiosa de relacionamiento, donde se reúnen los vecinos y paravecinos de Chile, estando presentes países como Brasil y Argentina, importantes socios chilenos en materia de política exterior y de defensa. Junto a la relevancia de las interacciones con tales países, el encargado del tema del Consejo de Defensa Suramericano en el Ministerio de Defensa 
Nacional de Chile, señor Carlos Maldonado, destacaba el año 2015 también que la participación en dicho organismo regional ha permitido igualmente incrementar el diálogo y la cooperación con otros países de la región, como es el caso de Perú y Venezuela, países con los cuales cabría suponer importantes divergencias en otras instancias. ${ }^{73}$

Hasta el presente, como se explicó en un capítulo anterior, ciertos lineamientos generales han guiado el desarrollo del Consejo, los cuales pueden resumirse como sigue: primero, que el organismo no pretende constituirse como una alianza militar; segundo, que es un Consejo de Defensa y no de Seguridad; tercero, que no fue establecido contra ningún país en particular; y cuarto, su gradualidad y flexibilidad, donde cumple un rol relevante el que las decisiones sean adoptadas mediante el consenso. Según Carlos Maldonado, la participación chilena está firmemente basada en tales principios, los que ha favorecido desde la misma creación del órgano.

Cabe señalar que la opción chilena por apoyar desde sus orígenes la constitución del Consejo no involucra una determinada concepción geopolítica, inclinada a favorecer la integración de América del Sur -como sí lo es para Brasil, preocupado de México, su competidor por el liderazgo regional-, por sobre la integración de América Latina en su conjunto. Más bien, desde la perspectiva de Chile, el establecimiento y desarrollo del órgano representa una manera de sumar esfuerzos por avanzar en la integración de América Latina como un todo, dejando la puerta abierta para la eventual adhesión de nuevos miembros. Gonzalo García ha señalado lo siguiente al respecto:

"...construir identidad suramericana en defensa, que tome en cuenta características subregionales y nacionales y que contribuya al fortalecimiento de la unidad de América Latina y Caribe se inscribe en la trayectoria histórica de Sudamérica. No es una identidad cerrada puesto que apela abiertamente a la condición latinoamericana referida en el Estatuto como una perspectiva de

\footnotetext{
${ }^{73}$ Entrevista personal concedida el 27 de octubre de 2015.
} 
integración futura de cualquier país de América Latina y el Caribe" (Ministerio de Defensa Nacional de Chile, 2009: 39-40).

Al igual que ante los diversos procesos de integración en marcha en la región, Chile ha asumido con moderación y pragmatismo su participación en el Consejo, por cuanto ésta no ha supuesto romper con los mecanismos de defensa y seguridad hemisféricos, como son las Conferencias de Ministros de Defensa de las Américas, la JID y la Comisión de Seguridad Hemisférica de la OEA. ${ }^{74}$

Esta postura de pragmatismo es comprensible, dado que, con todas sus limitaciones, el sistema hemisférico continúa aportando a la estabilidad continental y a la agenda nacional de cooperación en seguridad y defensa. Tampoco debe olvidarse que la participación chilena en tales mecanismos supone el apoyo también a los países más prominentes del continente, como son Estados Unidos y Canadá, socios relevantes para el país del Cono Sur. El Director de Seguridad Internacional y Humana de la Cancillería chilena, Julio Bravo, confirma estos argumentos, señalando que "nuestra participación en el CDS no es contra nadie, ello supone no excluir nuestras relevantes relaciones con otros países del hemisferio, como Estados Unidos. Desde Chile valoramos el sistema hemisférico". ${ }^{75}$

En la misma línea de moderación es que Chile sostiene la idea de que el Consejo sólo abarque aquellos temas tocantes a los asuntos de defensa. Esta tendencia posiblemente se mantendrá, atendidas las heterogeneidades que se aprecian en la región respecto del modo en que los países miembros del organismo conciben o conceptualizan los aspectos relacionados con la seguridad y la defensa, lo que consecuentemente impacta en las tareas que asumen las respectivas fuerzas

\footnotetext{
${ }^{74}$ Cabe señalar a este respecto, que otros países del Consejo han planteado ciertamente una posición distinta a la chilena. Es el caso de Venezuela, que en variadas ocasiones ha propugnado la idea de avanzar en una OTAS, una suerte de OTAN Sudamericana, identificando a Estados Unidos como un enemigo común de la región y sosteniendo, al mismo tiempo, la necesidad de que el CDS contemple en su agenda otras tareas que caerían en el ámbito propio de la seguridad pública. Lo anterior, de la mano de fuertes impugnaciones y denuncias frente al sistema hemisférico.

${ }^{75}$ Entrevista personal concedida el 19 de octubre de 2015.
} 
armadas. Es decir, las dificultades que aún se aprecian en alcanzar conceptualizaciones y metodologías comunes en estas materias, desde luego, afectarán la profundización de la integración en tal sentido.

Respecto de los temas que contempla la agenda del Consejo, y dada su experiencia política en ciertas temáticas, Chile impulsó en un principio el tratamiento de materias como la modernización de los Ministerios de Defensa y la homologación de los gastos. En la actualidad, el trabajo chileno se ha concentrado en los asuntos de género, relacionados con la aplicación de la resolución 1325 del Consejo de Seguridad de Naciones Unidas sobre Mujer, Paz y Seguridad; el enfrentamiento de situaciones de desastres naturales $\mathrm{y},{ }^{76}$ vinculado con ello, los efectos del cambio climático; crecientemente ha demostrado también interés por la esfera de la industria de la defensa; y, por último, por el área de la formación y capacitación. ${ }^{77}$ Destaca en tal sentido el protagonismo de Chile en la creación de un Grupo de Trabajo sobre Perspectiva de Género en el CDS, que aparece en los planes de acción 2016 y 2017, en continuidad con la organización en 2015 de un seminario sobre integración de la perspectiva de género en el ámbito de la defensa (plan de acción 2015). En la misma línea, cabe subrayar la celebración, en Santiago de Chile, del primer y segundo curso sobre perspectiva de género en defensa, que figuran en los planes de acción 2016 y 2017, respectivamente.

Un tema que cabe subrayar especialmente, es el enfrentamiento de los desastres naturales, temática que excedería aquellas preocupaciones vinculadas con el concepto específico de la defensa. A este respecto, en una entrevista realizada al ex Ministro de Defensa Nacional, Jorge Burgos, por parte de la revista Patria de Ecuador, este subrayó los aportes de Chile en la formulación de los lineamientos para la protección de los recursos naturales en la región y en la elaboración del Atlas de Mapas de Riesgo de Desastres Naturales en Suramérica (Burgos, 2014). Si bien estas temáticas se relacionan con los asuntos propios de la seguridad, de

${ }^{76}$ En este aspecto, cabe destacar que, en el marco del Grupo de Trabajo sobre Gestión del Riesgo de Desastres del CDS, Chile organiza anualmente el Ejercicio UNASUR, con el objeto de promover la conformación de un sistema regional de cooperación en defensa para que, en caso de emergencias o catástrofes naturales, se generen redes de apoyo bajo un protocolo de cooperación mutua (planes de acción 2015, 2016 y 2017).

${ }^{77}$ En entrevista sostenida con Carlos Maldonado, del Ministerio de Defensa Nacional, el 27 de octubre de 2015 . 
todos modos, no contienen la carga política y efectos asociados que sí poseen otras esferas, como lo es la utilización de los medios militares para el combate contra el narcotráfico y el crimen organizado. En Chile, el empleo de las fuerzas armadas ante situaciones de desastres naturales ha sido altamente valorado por la ciudadanía, representando una relevante oportunidad de interacción civil-militar. Estas experiencias, a lo que se agrega la exposición del país a un amplio abanico de desastres naturales -entre los que se cuentan sequías, incendios forestales, inundaciones y terremotos, muchos de los cuales han ocurrido de manera simultánea- han estado al centro de los últimos aportes de Chile a los trabajos del Consejo.

Además de los tópicos antes señalados, también cabe recalcar el énfasis chileno en lo referente a la generación de una comunidad epistémica y la formación de un pensamiento estratégico regional. La relevancia que Chile ha otorgado a la promoción de estas materias explica el empeño puesto en la candidatura del académico chileno Mladen Yopo para ejercer la Subdirección del CEED. Su elección se realizó, por consenso, durante la XI Reunión de la Instancia Ejecutiva del CDS, celebrada en Montevideo entre los días 10 y 11 de diciembre de 2014 .

En el fondo, la participación de Chile en el Consejo demuestra la opción del país por favorecer un entorno estable y coherente con su modelo de desarrollo abierto al mundo, pero con una perspectiva latinoamericana. Ello se concatena con una política de defensa que crecientemente acrecienta sus rasgos cooperativos, que deja de lado la idea de asumir a los vecinos como parte de las amenazas $y$, al revés, pasa a valorarlos como socios en una tarea común de desarrollo y bienestar, o sea, como parte fundamental del quehacer de favorecer, de manera cooperativa, un entorno regional seguro y estable. Reforzando estos argumentos sobre el apoyo chileno hacia el Consejo en su aporte a la seguridad regional, el ex Ministro de Defensa Nacional, Jorge Burgos, ha sostenido que:

"Recientemente, la Presidenta Bachelet señaló en un párrafo específico el rol de Chile en la UNASUR y el interés por convertirnos en un actor protagónico en la construcción de una Zona de Paz. Es una instancia que nos interesa, un camino 
importante que hemos elegido desde hace ya algunos años, que hay que cuidar y que hay que acrecentar" (Burgos, 2014: 174).

En el ámbito doméstico, es preciso igualmente señalar que el Consejo se ha constituido para Chile como una instancia relevante para apuntalar la coordinación del trabajo de los Ministerios de Relaciones Exteriores y de Defensa, con el objeto de proyectar regional e internacionalmente al país. El Director de Seguridad Internacional y Humana del Ministerio de Relaciones Exteriores de Chile, Julio Bravo, sostiene a este respecto que "la participación del país en el CDS ha representado un mecanismo valioso para ayudar a la mutua coordinación. El Ministerio de Defensa se ha acoplado a la idea de la convergencia en la diversidad. Defensa se ha transformado en un brazo de la política exterior". En síntesis, como es posible apreciar, de la mano de Brasil, Chile fue uno de los principales impulsores de este organismo regional. Para este país, el Consejo se ha transformado en una instancia apropiada para favorecer la estabilidad de la región, apoyando la generación de confianza entre los miembros y previsibilidad en las conductas, lo que consecuentemente ha disminuido la incertidumbre y reforzado la estabilidad de las relaciones entre los miembros. Por lo demás, en las reuniones del Consejo se aprecia un elevado nivel de interacción entre los países, no estando las conversaciones condicionadas por las fragmentaciones y alianzas que sí se aprecian en otros foros. O sea, en los encuentros del CDS es posible ver trabajar fluida y conjuntamente a delegaciones nacionales que en otras instancias tendrían fuertes divergencias. De hecho, por ejemplo, el mismo ex Ministro Burgos ha sido claro en subrayar el trabajo conjunto entre Chile y Perú en la elaboración del antes mencionado Atlas de Mapas de Riesgo de Desastres Naturales en Suramérica (Burgos, 2014).

En el fondo, para Chile, el Consejo ha favorecido el desarrollo de una comunidad pluralista de seguridad a nivel sudamericano, donde los países incrementan la confianza mutua, abandonando el recurso a la guerra como medio de solución de sus diferencias, lo que es particularmente coherente con el modelo de desarrollo chileno, cuyo comercio internacional requiere como condición de un ambiente regional e internacional seguro y estable. 


\section{c) El papel de Ecuador}

Junto a Brasil y Chile, Ecuador formó parte del Grupo de Trabajo para la conformación del Consejo de Defensa Suramericano siendo, a lo largo de su desarrollo, uno de los países más activos en dicho organismo regional, como lo expresa el haberse constituido el país en sede de la UNASUR y, en su marco, de la ESUDE. Ello forma parte de una tendencia general de apoyo, aunque no constante, de la política exterior ecuatoriana hacia la integración regional.

Caracterizando la política exterior de Ecuador, Abraham Quezada señala que los diversos y complejos procesos políticos domésticos, así como los escenarios externos, a nivel vecinal y regional, han determinado en dicho país la conciencia de ser un "Estado pequeño", lo que ha incidido fuertemente en sus interacciones con los países vecinos y en su posicionamiento en la región andina y sudamericana, lo que a su vez ha tenido efectos en una suerte de autoconciencia, respecto de "la conformidad de haber vivido en un estado de permanente vulnerabilidad externa". Tal situación se ha visto agravada por la debilidad institucional y económica interna, particularmente visible a fines de la década de los noventa y comienzos de la siguiente, caracterizada por "la sucesión de varios gobernantes en pocos años, el reemplazo forzado de su moneda por el dólar estadounidense, la falta de confianza en la clase política y la crisis económicofinanciera" (Quezada, 2016: 171-172).

Lo anterior también ha afectado el plano de la seguridad, considerando la pertenencia de Ecuador a una subregión cuya agenda ha estado dominada por el conflicto colombiano -ante el cual los gobiernos ecuatorianos han procurado tomar distancia-, la dificultad en el control de las fronteras -particularmente en la zona norte-, la estrategia contra las drogas promovida desde Estados Unidos y la constante turbulencia política que ha afectado a las instituciones del mundo andino (Bonilla, 2010: 217). A ello se agregan los complejos problemas de gobernabilidad derivados de la histórica competencia entre Quito y Guayaquil, así como de las variadas demandas de los pueblos indígenas, que dan cuenta de una sociedad con complejas fragmentaciones y fracturas. 
Respecto de la integración regional en particular, cabe destacar el activismo ecuatoriano en el marco de la CAN que, como señala Quezada, ha ocupado:

“...un importante espacio de sus preocupaciones, lo cual se reflejó en la retórica integracionista de sus autoridades, aunque en la práctica ello no fue acompañado por un compromiso lo suficientemente consistente con dicho proceso... aunque siempre manifestó voluntad política de apertura e interés hacia los temas de la agenda de integración regional, siendo su pertenencia al Pacto Andino, uno de los dos grandes ejes de la integración sudamericana" (Quezada, 2016: 173).

Para Ecuador, la integración representa una relevante herramienta de desarrollo vinculada, entre otros aspectos, con la posibilidad de contar con un mercado ampliado, pese al escaso rendimiento que en su historia expresó el Pacto Andino, sometido a severas crisis durante la década de los setenta, así como también su sucesora, la CAN, fuertemente afectada por el modesto desempeño económico de sus miembros, frecuentemente víctimas de graves crisis políticas institucionales. A ello puede agregarse el bajo nivel de cumplimiento, por parte de los países, de los compromisos asumidos en el marco de la integración subregional, especialmente en lo relacionado con la mantención de políticas proteccionistas y la poca disposición a la apertura de sus mercados domésticos.

De tal modo, en un contexto de fragmentación subregional, como efecto de las fuertes diferencias entre los países andinos, especialmente en términos de liderazgos, modelos de desarrollo y divergencias políticas entre los gobiernos, sin olvidar el peso del interés nacional en desmedro de los intereses subregionales, "La ola regionalista de comienzo de los años noventa sorprendió a Ecuador en medio de una profunda inestabilidad política y social, manifestada en crisis constantes y cambios de presidentes, quienes no alcanzaban a concluir su mandato" (Quezada, 2016: 175), lo que consecuentemente afectó su posicionamiento en torno a la integración regional. 
Este marco de profundo desprestigio de la integración andina llevó al Presidente Correa a optar por la concertación en el marco de la UNASUR y el ALBA, esquemas típicos de la integración posliberal que impregna las relaciones intrarregionales desde principios del siglo XXI. La prioridad que puso la administración Correa en la actividad ecuatoriana en la UNASUR lo llevó a promover que dicha entidad regional se radicara en Quito, bajo la dirección del ex Presidente Rodrigo Borja como su primer Secretario General. Aunque más adelante, el entusiasmo del Mandatario ecuatoriano se iría moderando, llegando a sostener que el establecimiento de la señalada institución regional había sido un "error estratégico", que se estaba transformando "al ritmo de los más lentos" y que paulatinamente había devenido en una institución burocratizada, cuya lentitud derivaba de que su toma decisiones involucraba la generación de consensos regionales, muchas veces difíciles de alcanzar (Quezada, 2016: 176).

Antes que la integración regional, han sido los temas bilaterales fronterizos los que han marcado la agenda de la política exterior de Ecuador, lo que también ha dado últimamente a la defensa un rol protagónico. En 2002 se editaría por primera vez un Libro Blanco de la Defensa Nacional, que contaría con una nueva versión hacia fines del gobierno de Alfredo Palacio. Este nuevo rol de la defensa en el marco de la proyección internacional de Ecuador, se vincula con una serie de cambios internos en esta materia, relacionados con el favorecimiento de la conducción política civil, en un contexto institucional donde las fuerzas armadas habían mantenido históricamente una notoria influencia política y altos niveles de autonomía, participando en varios golpes de Estado, como fue en 1996, 2000 y 2005.

Junto al favorecimiento de la supremacía civil, a cargo del Ministerio de Defensa Nacional, los cambios han involucrado la eliminación de la conscripción obligatoria, la no deliberación política de las fuerzas armadas, la supresión de la facultad de ser garantes de la constitución ecuatoriana, el impulso a la capacitación y profesionalización del sector, así como a la mejora de las capacidades materiales de las fuerzas armadas, "una de las instituciones de mayor legitimidad y credibilidad a nivel nacional", a juicio de Fredy Rivera, ex 
Subsecretario de Coordinación Política del Ministerio de Gobierno, Policía y Cultos República del Ecuador (Rivera, 2009: 48).

Aunque cabe señalar que lo recién enunciado ha tenido últimamente ciertos matices, como lo expresan las serias divergencias entre el Presidente Correa y las fuerzas armadas de Ecuador, que han desembocado, entre otros resultados, en la remoción de las cúpulas militares. Los distintos puntos de roce entre el Presidente y los mandos militares han involucrado temas como la reforma de la Ley de Seguridad Pública, en mayo de 2014, que establece que las fuerzas armadas deben apoyar las labores de la policía; el traspaso de colegios y hospitales militares al Estado; la eliminación de edecanes y agregadurías militares en el extranjero; el fortalecimiento de la Secretaría Nacional de Inteligencia (SENAIN), en desmedro de la dirección de inteligencia de las fuerzas armadas; y la destitución del Alto Mando. ${ }^{78}$

Por otro lado, desde la perspectiva de Ecuador, el conflicto en Colombia ha representado un escollo para avanzar en el camino de la integración. Ante este escenario, Ecuador ha puesto en práctica una política de "contención y profilaxis" (Bonilla, 2010: 217), considerando particularmente su impacto en la zona de frontera, implementando diversas medidas tendientes a controlar la migración y la prevención de lo que desde este país se ha considerado como "contaminación" de la violencia.

También han significado un obstáculo las diversas amenazas a la seguridad derivadas del narcotráfico, ante las cuales el país ha llevado a cabo una reforma de su sistema penal, modificado leyes financieras para controlar el lavado de dinero y reformado sus sistemas policial y militar, a lo que se une la concesión en 1999 de una base aérea a Estados Unidos en la localidad de Manta -siendo cerrada en septiembre de 2009- con el objetivo de desarrollar labores de vigilancia y control aéreo del territorio de Ecuador, sur de Colombia, norte de Perú y de la

\footnotetext{
${ }^{78}$ Véase al respecto la nota "Rafael Correa mide su poder con las fuerzas armadas". Disponible http://internacional.elpais.com/internacional/2016/09/01/america/1472764437_592400.html Revisado en marzo de 2017.
} 
vertiente pacífica nor-occidental de América del Sur (véase Bonilla, 2010: 218221).

En el plano vecinal de Ecuador, mientras la relación con Colombia se ha concentrado en aspectos vinculados con la seguridad pública, particularmente en aquellos temas relacionados con el crimen organizado y con las ramificaciones del conflicto interno colombiano, las relaciones con Perú se concentraron, desde fines de los noventa, en el relanzamiento del Plan Binacional de Desarrollo de la Región Fronteriza, contemplado en los acuerdos de 1998. Tal iniciativa se plasmaría luego en el "Plan Binacional Perú-Ecuador", relanzado en marzo de 2004, con el objeto de dinamizar la economía de la zona de frontera, mediante una ingente actividad pública y privada. Así las cosas, en junio de 2007 ambos países celebrarían la Reunión Biministerial en Tumbes, donde los Presidentes de Ecuador y Perú destacarían que, entre dichas naciones, "se encontraban cerrados todos los litigios y que no había ningún conflicto o reclamación pendiente" (Quezada, 2016: 186).

De este modo, en un contexto donde los litigios fronterizos perdían fuerza, desde la Cancillería ecuatoriana cobraba nueva relevancia el rol del país en la integración regional. En tal sentido, en un documento del Ministerio de Defensa Nacional del Ecuador, aparecido en la revista Patria de dicha Secretaría de Estado, se señala que el:

“...esfuerzo integracionista manifiesta e impulsa un proceso de creciente confianza entre los Estados, de relaciones colaborativas y de búsqueda de respuestas a problemas comunes, como el necesario replanteamiento de la región, de sus condiciones internas actuales y de sus potencialidades de inserción en el sistema mundo contemporáneo...La integración implica el diseño de políticas comunes, la coordinación de acciones, la mayor vinculación y correspondencia de nuestras legislaciones, y la mayor fluidez de comunicaciones y vínculos directos que se desprende de la relación permanente entre gobiernos y pueblos, así como de centros académicos y de los representantes de los 
organismos estatales relacionados con la defensa y la seguridad regional" (Ministerio de Defensa Nacional del Ecuador, 2014:179).

De este modo, la integración encontraría, para Ecuador, una singular y pragmática manera de avanzar a través del camino de la defensa, lo que consecuentemente ha tenido un efecto en la participación del país en el Consejo de Defensa Suramericano, como será posible apreciar en el siguiente acápite.

\section{Ecuador y la integración en el ámbito de la defensa. Una mirada al Consejo de Defensa Suramericano}

Respecto de los aspectos de defensa de la integración regional, es necesario primeramente señalar que Ecuador ha sido un fuerte crítico del sistema hemisférico de seguridad y defensa, orquestado desde la OEA, acusándolo de anacronismo y de ser un instrumento meramente dependiente de los intereses de Washington, los que se han concentrado en la estrategia contra el narcotráfico y el conflicto colombiano. En tal sentido, el diplomático ecuatoriano Pablo Villagómez, resumiendo las diatribas que se han lanzado sobre el sistema hemisférico de seguridad y defensa, se ha referido en los siguientes términos:

"Uno de los medios más eficaces utilizado por los Estados Unidos para imponer su dominio colonial en el hemisferio consistió en alinear los países latinoamericanos con la agenda de Washington, impulsando un modelo de cooperación hemisférica marcado por la imposición y el asistencialismo..." (Villagómez, 2014: 207).

En complemento de tales argumentos, la diplomática ecuatoriana María Augusta Calle ha sostenido que:

"Actualmente, los países americanos no sólo enfrentan una amenaza de intervención militar de carácter extracontinental, sino que el escenario geopolítico mundial, el ejercicio de poder y el 
carácter mismo de la agresión cambiaron radicalmente" (Calle, 2014: 225).

Esta percepción de crisis de la institucionalidad hemisférica ha llevado a Ecuador a impulsar el diseño y creación de una nueva arquitectura de seguridad a nivel regional sudamericano, lo que se ha concretado en el Consejo de Defensa de la UNASUR. De manera concordante con lo anterior, el ex Ministro de Defensa ecuatoriano, Fernando Cordero, planteaba en 2015 que resultaba un imperativo regional el avanzar hacia una "nueva arquitectura que enfoque sus esfuerzos hacia la reconfiguración de estrategias nacionales, que puedan reducir las asimetrías entre los países miembros de la UNASUR"79.

En línea con ello, en la Agenda Política de la Defensa 2014-2017, elaborada por el Ministerio de Defensa Nacional del Ecuador y publicada en 2014, se señala que:

\begin{abstract}
"El Ecuador se posiciona como un país soberano y digno que establece relaciones horizontales con todos los países. Esto se manifiesta en casos como la renegociación de la deuda externa, las nuevas condiciones de los contratos petroleros, la denuncia del Tratado Interamericano de Asistencia Recíproca (TIAR), y la suspensión de su participación en las instancias del Sistema Interamericano de Defensa como la Junta Interamericana de Defensa (JID) y el Colegio Interamericano de Defensa (CID), entre otros" (Ministerio de Defensa Nacional del Ecuador, 2014: 23).
\end{abstract}

También, la Agenda Política de la Defensa es explícita en sostener la crisis del sistema interamericano, señalando que en su reemplazo debiera avanzarse a nivel sudamericano:

\footnotetext{
79 "Ecuador: una nueva visión de defensa y soberanía en el marco de UNASUR". Disponible en http://www.infodefensa.com/latam/2015/10/01/opinion-ecuador-nuevavision-defensa-soberania-marco-unasur.php
} 
"En este sentido, es necesario reconocer la crisis de institucionalidad del llamado sistema interamericano de defensa, y avanzar en el diseño y creación de una nueva arquitectura de defensa regional, colaborativa y cooperativa, con identidad propia y arraigada en las necesidades, posibilidades y prioridades de América Latina y del Caribe. Para el Ecuador, la arquitectura de seguridad y de defensa del siglo XXI debe estructurarse y fundamentarse en los nuevos mecanismos regionales como el Consejo de Defensa Suramericano y la Escuela Suramericana de Defensa de CDS-UNASUR, promovida por Ecuador..." (Ministerio de Defensa Nacional del Ecuador, 2014: 33).

De este modo, para Ecuador, el ámbito de la defensa sería una de las áreas puntales de la integración regional, bajo la perspectiva de la política exterior y de la política de defensa. Fredy Rivera, Subsecretario de Coordinación Política del Ministerio de Gobierno, Policía y Cultos República del Ecuador al momento de establecerse el Consejo de Defensa Suramericano, e integrante del Grupo de Trabajo que le dio forma, el año 2009 señalaba en tal sentido que:

"Si bien hasta hace poco tiempo, el tema de la integración suramericana en defensa estaba por lo general ausente en foros oficiales e incluso en los alternativos, los nuevos escenarios políticos han permitido pasar de las retóricas y declaraciones a la concreción de un organismo que viabilizará instrumentos prácticos y efectivos para la cooperación en distintas áreas de la defensa. Pongo énfasis en la consulta, en la cooperación y en la coordinación porque a más de ser principios fundacionales del CDS, constituyen también piezas claves en los programas y fundamentos de la política de Defensa del Ecuador que mantiene una actitud estratégica basada en conceptos defensivos y orientaciones proactivas" (Rivera, 2009: 43-44). 
Ecuador ha encontrado en su trabajo en el Consejo una manera pragmática de dar contenido y operatividad a la integración regional, en un contexto marcado por la diversidad de los gobiernos, donde no han estado ausentes los roces bilaterales, como fue el caso de la fuerte crisis generada con Colombia, a propósito del traspaso de contingente militar de éste país sobre la frontera ecuatoriana, en el contexto de la denominada operación Fénix. Este hecho resulta particularmente relevante bajo el prisma de la seguridad regional, por cuanto generó graves turbulencias que derivaron en la ruptura de relaciones diplomáticas entre Ecuador y Colombia, lo que fue seguido por Venezuela y Nicaragua.

En su momento, el gobierno de Ecuador denunció el acto ante la OEA, señalando que las acciones de Colombia transgredían el derecho internacional, violando la soberanía y la integridad territorial ecuatorianas. Por su parte, Colombia acusó a Ecuador y Venezuela de mantener relaciones con las FARC, al mencionar que en los computadores encontrados en el campamento se había encontrado información que vinculaba a los gobiernos de esos países con la guerrilla. Las tensiones llegaron incluso a la movilización de tropas a la frontera, lo que sólo se superó una vez que la OEA rechazó la incursión armada de Colombia sobre Ecuador, aunque sin condenar a Bogotá, tal como lo solicitaba el gobierno ecuatoriano (Bonilla, 2010: 230).

Al igual que Brasil y Chile, la participación de Ecuador en el Consejo de Defensa se ha asumido de manera moderada, en el sentido de proponer que dicho organismo se constituya como un foro de cooperación y coordinación, antes que como un denso mecanismo de seguridad colectiva, como ha sido propuesto en distintas ocasiones por los gobiernos de Venezuela y Bolivia, con los cuales comparte espacio en el ALBA. En esta línea, cabe subrayar lo señalado en 2009 por el ex Subsecretario Rivera quien, junto con celebrar el establecimiento del Consejo, era explícito en valorar la creación del organismo como una manifestación del consenso y acuerdo entre los países de la región, marcados por la diversidad de sus gobiernos y en su apreciación sobre el contexto internacional. En sus propias palabras: 
"En poco menos de un año, con intereses subregionales difíciles de consensuar debido a posiciones políticas coyunturales que frenaron en determinados momentos las negociaciones; con violaciones a la soberanía nacional como la ocurrida a mi país el primero de marzo de 2008 por parte de las fuerzas militares de Colombia; con la presencia de compromisos adquiridos por algunos países con la potencia hegemónica hemisférica e inclusive, con reparos y desconfianzas hacia los procedimientos previamente acordados; los países involucrados en este compromiso pudimos evacuar con mucha habilidad una serie de distancias conceptuales e interpretaciones ideológicas disímiles para dar paso a la concreción de este importante organismo de la UNASUR" (Rivera, 2009: 43).

En una entrevista realizada a la ex Ministra de Defensa Nacional de Ecuador, María Fernanda Espinoza, aparecida en la revista Patria en 2014, se le consultaba sobre su opinión en torno a los cambios que actualmente se están produciendo en el plano geopolítico mundial y regional, así como respecto de las características que ha asumido la participación del Ministerio de Defensa de Ecuador en el marco de la UNASUR y la CELAC. En su respuesta, la entonces Ministra daba cuenta del valor que ese país otorga a la integración regional, como herramienta de inserción internacional, al mismo tiempo que destacaba el papel de la defensa en el contexto de un proceso verdaderamente integral y multidimensional de concertación.

Así las cosas, a juicio del gobierno ecuatoriano, la integración regional formaría parte de una estrategia de inserción global, que apunta en último término a la construcción de un mundo multipolar, donde la región podría jugar un rol fundamental, atendida su situación como una Zona de Paz. En suma, solo a través de la integración la región podría tener una voz en el concierto internacional. En palabras de la ex Ministra Espinoza: 
"A esta altura, los temas de integración regional ya no son una opción para nuestros países: no es que escogemos integrarnos o no y que podemos deliberar sobre esa cuestión. Yo creo que es una necesidad imperiosa la de trabajar en los procesos de integración regional porque quizá en el escenario actual se trate de la única forma de supervivencia.... la única manera de sobrevivir de nuestros pueblos, de proyectarnos hacia el futuro, de construir nuestros propios modelos de sociedad de acuerdo a nuestra propia historia, de vincularnos con nuestros propios hermanos, de crecer todos los días como seres humanos es a través de la integración, es decir, de construir lazos de comunidad y de pensamiento común en la diversidad y en la diferencia...Nuestros países en América Latina, y en particular en Suramérica, han comprendido muy bien que la forma de sobrevivir en proyección y en fortalecimiento mutuo consiste en la integración regional... hoy hemos entendido que la integración tiene que ser "íntegra" y tiene que pasar por todos los caminos, es decir, no sólo por el económico y comercial sino también por el cultural, el tecnológico, y el de la defensa y la seguridad: por eso hemos creado el Consejo de Defensa Suramericano de UNASUR" (Espinoza, 2013: 144-145).

Este enfoque sobre la integración regional y el mundo trasciende la mirada ecuatoriana sobre el Consejo de Defensa Suramericano. Entre los principios que guían la actividad ecuatoriana en el marco del Consejo, cabe destacar el respeto irrestricto a la soberanía de los Estados, la integridad e inviolabilidad de las fronteras, así como la no intervención en asuntos internos y la autodeterminación de los pueblos. Lo antes señalado resulta particularmente relevante, si se considera que el Consejo se creó en un contexto político regional convulsionado por la violación de la soberanía territorial ecuatoriana por parte de un contingente militar de Colombia. De este modo, en un marco donde la figura de Estados Unidos, tan presente en su país vecino, era apreciada con precauciones desde 
Ecuador, el tema de la autonomía regional estará en un lugar prioritario al momento de apoyar las labores del organismo. Como se señala en la Agenda Política de la Defensa 2014-2017:

"Uno de los elementos que se evidencia en los últimos años es que los problemas y conflictos de América del Sur deben ser resueltos en la propia región, sin tutelajes externos y mediante el diálogo, herramientas fundamentales para la consolidación de Suramérica como una región de paz". (Ministerio de Defensa Nacional del Ecuador, 2014: 22).

Temas prioritarios de Ecuador en el Consejo de Defensa -los cuales han quedado reflejados en los respectivos planes de acción anuales- son el intercambio de experiencias en el plano estratégico, la transparencia en el gasto militar y el desarrollo de una industria militar suramericana, con miras al fortalecimiento de la autonomía estratégica regional. En esta línea, el antes citado Subsecretario Fredy Rivera se ha manifestado en los siguientes términos:

"Desde esa perspectiva, los esfuerzos compartidos que se desplieguen para desarrollar una industria militar autónoma que pueda garantizar el suministro necesario en tiempos de crisis, será una oportunidad histórica para Suramérica, ya que ampliará sus márgenes de autonomía y construirá capacidades defensivas para la región en momentos donde los recursos naturales estratégicos están siendo analizados por las grandes potencias extra regionales" (Rivera, 2009: 47).

Junto con el tema de la transparencia y el desarrollo de una industria estratégica regional, como mecanismos que refuerzan la autonomía de la región, una especial preocupación de Ecuador recaerá en el ámbito doctrinario, recalcando la necesidad de generar conceptos, categorías y doctrinas regionales propias, "que inviten a repensar nuestra realidad a la luz de los procesos sub-regionales de 
integración y de la crisis evidente de las caducas concepciones de la seguridad nacional y hemisférica que heredamos de la Guerra Fría y de todas sus variaciones posteriores" (Ministerio de Defensa Nacional del Ecuador, 2014: 179). Ya desde los orígenes del Consejo, Ecuador acogerá enérgicamente:

“...la propuesta de crear un Centro Suramericano de Estudios Estratégicos y en el futuro inmediato desarrollar una Academia o Colegio Suramericano de Defensa. Estos temas nos convocan fuertemente porque el solo hecho de debatir sobre nuevas bases conceptuales y doctrinarias que configuren una identidad suramericana, constituye, de por sí, un paso en firme para comprometernos en esa convocatoria... Los nuevos escenarios geopolíticos y geoestratégicos requieren asumir ese reto como factor central de una nueva política de la defensa nacional a la par de plantearse el desarrollo de capacidades de previsión e inteligencia estratégica que produzca teoría y pensamiento propio en defensa" (Rivera, 2009: 46).

También la Agenda Política de la Defensa 2014-2017 recogerá tales argumentaciones respecto de la necesidad de fortalecer el pensamiento estratégico regional, en tanto el Consejo de Defensa "muestra un claro compromiso por desarrollar una visión compartida y construir una identidad suramericana en materia de Defensa, al tiempo de fortalecer la capacidad de la región en este campo". Esta voluntad política de generar un pensamiento estratégico común se implementaría en el CEED, con sede en Buenos Aires, cuyas labores se verían complementadas desde Quito con la instalación de la ESUDE, creada en febrero de 2014 (Ministerio de Defensa Nacional del Ecuador, 2014: 22). En esta línea, a juicio del gobierno de Ecuador, la creación de la ESUDE, generada por iniciativa de ese país, "constituiría un pilar fundamental para el fortalecimiento de la identidad, la doctrina y el pensamiento estratégico comunes en materia de Defensa" (Ministerio de Defensa Nacional del Ecuador, 2014: 37-38). 
Durante el discurso inaugural de dicha entidad en Quito el año 2015, en el contexto del aniversario de la UNASUR, el Presidente Rafael Correa señalaría que, considerando "la integración en la que avanza inexorablemente América Latina... es hora de que ideemos un pensamiento estratégico suramericano, es crítico que formemos a nuestros civiles y militares dentro de ese marco". ${ }^{80} \mathrm{De}$ manera congruente con lo anterior, en los planes de Acción de 2016 y 2017 del Consejo de Defensa Suramericano, Ecuador aparece liderando el trabajo destinado al diseño de los contenidos del Primer Curso Suramericano de Defensa y Pensamiento Estratégico, que se espera sea incorporado de manera permanente en el programa de la ESUDE.

Complementando lo antes expuesto, es necesario señalar que la activa labor de Ecuador en el seno del Consejo se explica bajo su concepción del sector defensa, que lo aprecia como parte de una estrategia global de desarrollo, que involucra una serie de vectores relacionados con la novedosa idea del "buen vivir". Es decir, la política de defensa, en estrecha coordinación con la política exterior, trabajarían armónicamente en torno a un desarrollo social sustentado teóricamente en la señalada noción, idea que incluso se encuentra plasmada en la Constitución de Ecuador, en cuyo preámbulo se señala que:

“...celebrando a la naturaleza, la Pacha Mama, de la que somos parte y que es vital para nuestra existencia (...) decidimos construir una nueva forma de convivencia ciudadana, en diversidad y armonía con la naturaleza, para alcanzar el buen vivir, el sumak kawsay; Una sociedad que respeta, en todas sus dimensiones, la dignidad de las personas y las colectividades" ${ }^{81}$

${ }^{80}$ Véase la nota de prensa "UNASUR inaugura Escuela Suramericana de Defensa". Disponible en http://www.telesurtv.net/news/Unasur-inaugura-Escuela-Suramericana-deDefensa-20150417-0051.html

${ }^{81}$ Véase "El Buen Vivir en la Constitución de Ecuador". Disponible en http://www.secretariabuenvivir.gob.ec/el-buen-vivir-en-la-constitucion-del-ecuador/ Revisado en marzo de 2017. 
El "buen vivir" se trataría, en consecuencia, de un nuevo modelo de convivencia política, social y económica, basado en un desarrollo armónico con la naturaleza, donde el hombre forma parte de una red ecológica, en la cual todos los seres están interconectados e interdependientes. Esta idea fundamental ha impregnado la política de defensa de Ecuador y, por lo tanto, su participación en el Consejo de Defensa Suramericano.

En tal sentido, cabe señalar que la Agenda Política de la Defensa 2014-2017 sostiene que la defensa, como un bien público, "...nos involucra a todos y todas, a civiles y militares, por lo cual contribuimos conjuntamente al fortalecimiento de la democracia, consolidando el poder civil en la conducción de seguridad y defensa a nivel nacional".

Asimismo, bajo una concepción ampliada sobre la seguridad y la defensa, reconoce el hecho de que la misma Constitución de Ecuador establece que "...las Fuerzas Armadas constituyen una institución de protección de los derechos, libertades y garantías de los ciudadanos, es decir que tiene un rol vital en el Buen Vivir y en el fortalecimiento de la democracia". Considerando lo anterior, la Agenda Política de la Defensa está guiada por tres objetivos prioritarios:

-Garantizar la defensa de la soberanía e integridad territorial y participar en la seguridad integral

-Apoyar el desarrollo nacional en el ejercicio de las soberanías; y,

-Contribuir a la paz regional y mundial (Ministerio de Defensa Nacional del Ecuador, 2014: 10).

En concordancia con lo anterior, al Ministerio de Defensa ecuatoriano le corresponde profundizar su contribución al desarrollo, mediante el fortalecimiento de las industrias de la defensa y la "soberanía científico- tecnológica", a través de los institutos de investigación, apuntando a "la consolidación de la Defensa como un bien público y en el que también se valoren sus dimensiones social, ciudadana y patrimonial" (Ministerio de Defensa Nacional del Ecuador, 2014: 10). El desarrollo de la industria de defensa regional se encuentra, de este modo, en un lugar prioritario en la actuación de Ecuador en el Consejo de Defensa Suramericano. 
Si bien excede la temática de la defensa, y con el objeto de entregar un cuadro amplio sobre las preocupaciones de Ecuador en el marco de la UNASUR, es dable destacar que el activismo del país en el Consejo de Defensa va de la mano de su ingente labor en los temas de seguridad pública, que son abordados, a nivel regional, en el contexto del Consejo Suramericano en Materia de Seguridad Ciudadana, Justicia y Coordinación de Acciones contra la Delincuencia Organizada Transnacional.

Desde esta perspectiva, con el objeto de complementar el trabajo de este último consejo sectorial de la UNASUR, Ecuador ha propuesto la idea de establecer una Corte Penal Suramericana, destinada al juzgamiento de la delincuencia organizada transnacional. Dicha Corte corresponde a una propuesta de la Fiscalía General del Estado del Ecuador, entendida como una vía judicial internacional, con el objeto de integrar las normas jurídicas de los países miembros de la UNASUR y combatir con más eficacia los siguientes delitos y las infracciones conexas: Trata de Personas; Soborno transnacional; Lavado de activos; Tráfico ilegal de migrantes; Tráfico de armas de fuego, sus piezas y componentes y municiones; Tráfico llícito de Estupefacientes y Sustancias Sicotrópicas; Tráfico Ilícito de Bienes Culturales; Delitos Cibernéticos o por medios electrónicos y Falsificación de medicamentos.

Tal iniciativa ecuatoriana data del año 2011, no obstante, no cuenta hasta ahora con el acuerdo regional, señalando diversos países, como es el caso de Brasil y Chile, que la instancia vendría a formar parte de una suerte de sobreoferta de mecanismos regionales, sobreponiéndose y duplicando esfuerzos con la labor de otros organismos, como es el caso del recién mencionado Consejo Suramericano en Materia de Seguridad Ciudadana, Justicia y Coordinación de Acciones contra la Delincuencia Organizada Transnacional.

\section{d) Un liderazgo emergente en el Consejo de Defensa Suramericano. El caso de Argentina}

Según plantea el profesor Alejandro Simonoff, a mediados del siglo $X X$, junto con el fin de la Guerra Mundial, se inauguró un nuevo escenario internacional, donde 
el desplazamiento de Europa y el ascenso de la Unión Soviética y Estados Unidos impusieron renovados rumbos a la política exterior argentina. En tal escenario, los proyectos de inserción internacional se debatieron entre esquemas "autonomistas" y proyectos que implicaban el alineamiento de ese país con Estados Unidos (Simonoff, 2013: 16).

Los gobiernos civiles se caracterizaron por el refuerzo de una estrategia de cooperación con los vecinos, a nivel general, como lo demuestra el intento de crear un nuevo $A B C$ durante los tiempos de Perón, los Acuerdos de Uruguayana con Frondizi y los de la Cuenca de La Plata con Arturo Illia. Por su parte, los regímenes dictatoriales privilegiaron los supuestos geopolíticos que apreciaban a los vecinos como fuente de conflicto, tal cual lo demostraron las fuertes tensiones con Chile en torno a la cuestión del Beagle, dejando a ambos países al borde la guerra en el año 1978 (Simonoff, 2013: 17).

En un contexto de alta tensión de las relaciones exteriores, que tendría como punto de inflexión la Guerra de las Malvinas, la salida del poder de los militares y la vuelta de la democracia en 1983, implicaron una nueva apreciación internacional, que se orientó fuertemente a la reinserción internacional de Argentina, luego del aislamiento vivido por el país durante el régimen militar. Si con el Presidente Raúl Alfonsín este proceso sería fuertemente contestatario hacia Estados Unidos, con Menem la situación sería radicalmente distinta, variando hacia el pleno alineamiento con la superpotencia.

De tal modo, desde los noventa la inserción internacional de Argentina fue diferente a la chilena, explicada en un acápite anterior. Mientras la estrategia chilena se basaba en una lógica de mercado de carácter estable, con políticas de Estado afines, la inserción internacional argentina responde a una "estrategia de alcance funcional a una lógica de Estado y con políticas de mercado ajustables a los vaivenes internacionales y a las demandas y presiones políticas de sus instituciones domésticas y actores de la sociedad civil" (Morandé 2007: 35). A lo anterior, se agrega que el caso de Argentina corresponde a un actor con atributos de potencia regional en el ámbito sudamericano, sobre la base de variadas capacidades y recursos de poder, como son la relevancia de su territorio y recursos naturales. 
En el plano internacional, una particular notoriedad alcanzó Argentina en la década de los noventa, a través del envío de naves a la Guerra de Irak, su participación en operaciones de paz, la cooperación vecinal en el plano de la defensa, su reconocimiento como aliado extra OTAN en 1997 por parte de Estados Unidos y su participación en el G-20, entre otras instancias.

Sin embargo, su desempeño internacional se ha visto afectado por la falta de continuidad en sus políticas doméstica e internacional en el plano económico, a lo que se suman las debilidades estructurales de su sistema político. Lo anterior habría tenido un efecto relevante en la imagen exterior del país, muchas veces caracterizada por la "inestabilidad, desconfianza e imprevisibilidad" (Morandé, 2007: 46). El retroceso en términos de prestigio internacional fue especialmente notable tras la crisis de 2001, que impuso a los gobiernos una mirada centrada en los sucesos sociales y económicos al nivel doméstico.

Como es posible vislumbrar, y tal cual señala José Morandé, la inserción internacional del país ha experimentado "transformaciones estratégicas severas" desde la crisis financiera (Morandé, 2007: 50). Si durante la administración Menem, que coincide con el término de la Guerra Fría, la política exterior argentina se caracteriza por su cercanía a Estados Unidos -lo que ha sido calificado desde distintos sectores como "subordinación"- como proyección internacional de una política doméstica marcada por las reformas económicas neoliberales (teniendo la administración de Fernando de la Rúa altos grados de continuidad en esta línea); a partir de 2001 el gobierno del país modifica su modelo liberal en pos de la intervención y regulación del Estado. Ello fue particularmente visible con las administraciones de Néstor Kirchner y Cristina Fernández, durante las cuales se expresó, asimismo, un fuerte distanciamiento de Washington y otros actores occidentales.

En líneas generales, según señala Larocca, el estilo de política exterior de los gobiernos de Néstor Kirchner primero, y Cristina Fernández después, se caracterizaría por la "demonización" de la política exterior adoptada durante la década de los noventa -identificada como "alineamiento automático" con los intereses de Estados Unidos- y su reemplazo por un nuevo modelo de "relaciones maduras" con el país norteamericano. En el plano de la política exterior, lo anterior 
se plasmaría en una estrategia de soft balancing u oposición limitada, combinando, a la vez, elementos de colaboración y resistencia frente a los intereses de Washington. En la misma línea, también destacaría una nueva "identidad sudamericana", lo que se manifestaría en un renovado impulso de la integración regional (Larocca, 2012).

Con la llegada de Mauricio Macri, otra vez se avizoran cambios en materia de inserción internacional, lo que ha incidido en el ámbito de la defensa. El nuevo posicionamiento internacional de Argentina se evidencia con la visita del Presidente de Estados Unidos, Barack Obama, a Argentina en marzo de 2016, así como en la presencia en Washington de autoridades de defensa del país sudamericano en mayo del mismo año. Entre otros elementos, el relanzamiento de esta relación bilateral busca renovar el intercambio militar, con el objeto de apuntalar la presencia argentina en operaciones de paz, así como incrementar la cooperación en temas como los asuntos antárticos, mantenimiento de la paz, preparación y respuesta ante desastres naturales y la defensa en el plano hemisférico. Según señaló en Washington el Viceministro de Defensa argentino, Ángel Tello, se busca dar vuelta la página a una relación tensa, de manera de "establecer relaciones maduras en materia de defensa con Estados Unidos y no interferirlas con alicates". 82

En relación con la prioridad regional asumida por la política exterior argentina, en clave histórica, una especial trascendencia tuvo la firma señera del acuerdo de 1985 con Brasil, que marcó el "definitivo alejamiento del aislamiento regional y la búsqueda de una estrategia para enfrentar los desafíos de la creciente integración económica mundial” (Simonoff, 2013: 21). De este acercamiento derivaría en 1991 el establecimiento del MERCOSUR, bajo los supuestos del Regionalismo Abierto, delineado desde la CEPAL.

A lo anterior se une el progresivo acercamiento hacia su vecino trasandino, plasmado en la desactivación de una serie de diferendos durante la década de los noventa, lo que tuvo como determinante acicate el Acuerdo de Paz y Amistad de 1984. Como señala Simonoff:

\footnotetext{
${ }^{82}$ Véase "El gobierno retoma el intercambio militar con Estados Unidos". La Nación, 15 de mayo de 2016.
} 
"Si bien Chile ganó la soberanía de las islas en disputa, el nuevo tratado supuso no solo un nuevo paradigma para la resolución de los conflictos pendientes, aspecto reclamado por la Argentina desde los años 50 del siglo $\mathrm{XX}$, sino que también abrió las posibilidades de concertar una política más cooperativa" (Simonoff, 2013: 22).

No obstante, el cierto posicionamiento alcanzado por Argentina en la región durante la década de los noventa, que tuvo como referencia el liderazgo exhibido junto a Brasil en la constitución del MERCOSUR, tuvo un golpe con la crisis financiera de fines de los noventa. A partir de entonces Argentina pierde terreno en el plano regional, al mismo tiempo que iba ganando terreno la Venezuela de Chávez, que con su activismo en el ALBA, aparecerá secundando la posición predominante de Brasil hasta ese momento.

Con el gobierno de Mauricio Macri, Argentina busca retomar una posición de notoriedad en el plano internacional y regional, buscando relanzar las relaciones con Estados Unidos, otorgar nuevos ímpetus a las negociaciones entre el MERCOSUR y la Unión Europea y acercar posiciones entre el señalado bloque sudamericano y la Alianza del Pacífico, adoptando una agenda externa de corte liberal, que se aparta de ciertos países del eje ALBA y se acerca a aquellos de la vertiente pacífica. En palabras de la Canciller Susana Malcorra, "Hay un claro objetivo del Presidente de empezar a trabajar arduamente en una alianza real con los países del Pacífico y unir voluntades con las del MERCOSUR". ${ }^{83}$ De este modo, en un contexto regional marcado por las crisis internas de Brasil y Venezuela, para el gobierno de Argentina el momento actual parece representar una oportunidad para retomar el liderazgo en América del Sur, mediante el impulso de la convergencia entre el MERCOSUR y la Alianza del Pacífico.

${ }^{83}$ Véase la nota "Macri remarca su giro exterior y se acerca a la Alianza del Pacífico". La Tercera, 1 de junio de 2016. Disponible en http://www.latercera.com/noticia/macriremarca-su-giro-exterior-y-se-acerca-a-la-alianza-del-pacifico/ Recuperado en junio de 2016. 
Puesta en perspectiva, la opción regional de Argentina se expresaría tempranamente en el liderazgo asumido junto a Brasil en el establecimiento del MERCOSUR y, desde los inicios del siglo XXI, con su ingente actividad en la UNASUR, pese a su decaído posicionamiento internacional en aquel momento. En este plano, la participación y compromiso argentino con el Consejo de Defensa Suramericano se expresa particularmente con la instalación del CEED en Buenos Aires, cuyo primer Director fue el Secretario de Estrategia y Asuntos Militares de ese país, Alfredo Forti.

La política exterior hacia la región encontrará en la política de defensa una relevante base de apoyo, encontrando ambas políticas públicas una serie de puntos de encuentro en torno a una postura firmemente legalista respecto de las relaciones internacionales, con una decidida apuesta al multilateralismo y la cooperación, particularmente en el ámbito regional. En esta línea de argumentación, el Ministro de Defensa del Gobierno de Cristina Fernández, Arturo Puricelli, señaló en 2012 que "La unión, la cooperación y la integración en el plano continental siguen siendo para la Argentina la principal vía para vehiculizar nuestras aspiraciones en materia de paz, desarrollo y libertad" (Puricelli, 2012: 10). Lo anterior va de la mano de un sostenido esfuerzo, desde la recuperación de la democracia en ese país, por avanzar y consolidar la plena supremacía civil en la política de defensa, que ha pasado a formar parte de su estrategia de desarrollo nacional. Al igual que en gran parte de los países sudamericanos, hasta la década de los ochenta la política de defensa había estado bajo monopolio militar, “...quienes la habían sometido a su visión particular del mundo, a su criterio ideológico, y, sobre todo, a sus intereses corporativos, que a menudo confundían con el interés nacional, o, incluso, los equiparaban" (DerGhougassian, 2012: 14).

Según Khatchik DerGhougassian, durante el régimen militar se definió y aplicó una política de defensa bajo el contexto de una "guerra total", teniendo como base la Doctrina de Seguridad Nacional. En su vertiente externa, dicha política se estructuraba de acuerdo a los siguientes elementos:

-Las hipótesis de conflicto por disputas territoriales con Chile, que estuvieron a punto de provocar una guerra en 1978 evitada por la intermediación del Vaticano; 
-La competencia por el liderazgo regional con Brasil; y,

-El intervencionismo en los conflictos centroamericanos (DerGhougassian, 2012:15).

La derrota en la Guerra de las Malvinas el año 1982 significará un punto de inflexión en tal sentido, en tanto dejó al descubierto la incompetencia del régimen militar, en su apreciación sobre la realidad internacional, así como la baja capacidad y preparación de la Fuerza Aérea, la Marina y el Ejército, para enfrentar una potencia de orden mundial, como es el caso del Reino Unido. De esta manera, la Guerra de las Malvinas propiciaría una transición por derrumbe del antiguo régimen, lo que implicaría una redefinición de la política de defensa argentina, en el contexto de un régimen civil que buscaba la restauración del poder político sobre las fuerzas armadas, debilitándolas en pos de inhibir su regreso al poder. Así también, esta nueva mirada sobre la defensa se plasmaría en una clara distinción entre los ámbitos de la defensa externa y la seguridad interna, lo que consecuentemente tendría un efecto en el antiguo rol de los militares en el plano doméstico. Como señala Valeria Larocca:

"Mientras que la defensa nacional está dirigida a repeler agresiones estatales de origen externo y el instrumento estatal específico para hacerlo son las Fuerzas Armadas, la seguridad interior tiene que ver con las amenazas al orden doméstico relacionadas con ilícitos o desastres y el poder estatal especifico para enfrentarlas son la fuerzas policiales y de seguridad" (Larocca, 2012: 70).

De ese modo, rápidamente se impondría un claro predominio institucional por parte de los sucesivos gobiernos civiles y, a su vez, las instituciones militares comenzarían a desempeñar un rol crecientemente secundario y subordinado a las autoridades constitucionales (Montenegro, 2012: 162). En el mismo tenor, DerGhougassian plantea que las fuerzas armadas argentinas vivirían, asimismo, un proceso de "ciudadanización", que terminaría con la percepción de la amenaza 
que aún persistía en la sociedad civil y, al mismo tiempo, permitiría la reconsideración de su rol en una visión estratégica de la inserción argentina en la región y el mundo (DerGhougassian, 2012: 19; 2011).

De ese modo, las fuerzas armadas abandonaban su rol como conductores del gobierno para, bajo una plena conducción civil, actuar en apoyo de la política exterior argentina. Así, a partir del año 2000 se impulsaría en el país la incorporación de una visión estratégica de las fuerzas armadas en la institucionalización de la política de defensa, mientras la modernización del sistema defensivo asumiría de manera fundamental los lineamientos principales de la política exterior argentina a partir de 1983, cuales son la integración regional y la cooperación internacional (DerGhougassian, 2012).

En el plano doméstico de la política de defensa, Germán Montenegro plantea la existencia de un proceso de institucionalización y de subordinación de las fuerzas armadas a las autoridades constitucionales, a partir del advenimiento de la democracia en Argentina. Haciendo un recuento de la institucionalidad legal del sector defensa, el autor destaca, entre otros, la ley de Defensa Nacional $N^{\circ} 23.554$ de 1988, que apunta a garantizar el ejercicio de la autoridad civil y la no intervención de las fuerzas armadas en asuntos políticos internos. A lo anterior contribuiría un contexto internacional entonces marcado por la desactivación del enfrentamiento Este-Oeste, el desarrollo de procesos integración y cooperación económica y el creciente diálogo político, particularmente en el Cono Sur sudamericano (Montenegro, 2012).

Entre otras normativas, Montenegro también destaca la ley de Reestructuración de las Fuerzas Armadas № 24.948 de 1998, que busca mantener a dichas fuerzas alejadas de las tareas de seguridad interior. Según el autor, la llegada de la administración de Néstor Kirchner implicaría el inicio de un cambio en la modalidad de la gestión de los asuntos de defensa y una alteración del patrón de relación civil-militar, que todavía se caracterizaba por una acentuada autonomía funcional del instrumento militar, hacia una manera efectiva para conducir, por parte del ámbito político, a la defensa y las fuerzas armadas. A este respecto, un importante rol cumpliría el Decreto $\mathrm{N}^{\circ} 727 / 06$, reglamentario de la ley $\mathrm{N}^{\circ} 23.554$ (Montenegro, 2012). 
Los lineamientos antes señalados sobre la política de defensa han tenido un alto nivel de permanencia. El año 2016, el Ministro de Defensa Julio Martínez señaló que "Hay una subordinación total al Presidente...los militares tienen hoy una misión profesional, que es la que manda la Constitución... Ya no hay Fuerzas Armadas al servicio de un gobierno o de un proyecto político. Están al servicio del Estado y de la democracia". Al presente, las fuerzas armadas argentinas cumplen labores en la custodia y conservación de los recursos naturales, operaciones de paz y tareas humanitarias. Asimismo, han dejado atrás los enfoques más clásicos de la geopolítica en torno a las hipótesis de conflicto para, al mismo tiempo, asumir plenamente un modelo de planificación por capacidades.

No obstante, el Ministro fue igualmente claro en señalar que aún quedan relevantes desafíos que enfrentar en la materia, por cuanto:

\begin{abstract}
"Hay incapacidades operativas muy grandes: aviones insuficientes, pocas horas de navegación y de vuelo, más almirantes que barcos. Los aviones Mirage, un símbolo de la Guerra de Malvinas, fueron desprogramados, y de los sesenta Pucará, apenas seis están en funciones". ${ }^{84}$
\end{abstract}

Últimamente destaca el debate suscitado en Argentina, a raíz de la desaparición del Submarino ARA San Juan. El hecho llevó el tema de la modernización de las fuerzas armadas a un lugar prioritario en el gobierno de Mauricio Macri, incorporando en la discusión política temas como presupuestos, mejoras de sueldos y la asignación de nuevos roles al instrumento militar, como aquellos relacionados con el enfrentamiento de catástrofes.

Las señaladas transformaciones internas en el plano de la defensa, así como la creciente coordinación con la política exterior, darían un sustento conceptual a la participación de Argentina en el Consejo de Defensa Suramericano, en el entendido que la modernización de la defensa debía considerar el énfasis puesto

84 "Fuerzas Armadas: con menos recursos y un nuevo paradigma". La Nación, 23 marzo 2016. Disponible en http://www.lanacion.com.ar/1882360-fuerzas-armadas-con-menosrecursos-y-un-nuevo-paradigma Recuperado en marzo de 2016. 
desde la vuelta a la democracia, en el plano de la diplomacia, respecto de la integración regional y la cooperación internacional.

En tal sentido, ya en el Libro Blanco de la Defensa Nacional del año 1999, se habla con una perspectiva optimista sobre la integración y sus efectos en la cooperación regional. En esta línea, se plantea que:

“...la intensificación del diálogo interamericano y los crecientes vínculos políticos han generado actitudes cooperativas, logrando diversos acuerdos tendientes a evitar, en la práctica, el uso de la fuerza para la solución de controversias -incluso las territorialestransparentar el desarrollo de tecnologías, especialmente la nuclear; la prohibición de armas de destrucción masiva y alcanzar entendimientos de todo orden" (Ministerio de Defensa de Argentina, 1999: 24).

Según señala Samuel Alves, en tal contexto, el MERCOSUR será apreciado especialmente por su naturaleza estratégica, como un elemento que favorecía la estabilidad regional, en tanto se constituía como un mecanismo que permitía la ampliación e institucionalización de prácticas de interlocución y cooperación relacionadas con el ámbito estratégico-militar, antes que en su condición de instrumento de integración económica y comercial. De este modo, según Alves, "El regionalismo, al final de la década del 90 , se presentaba en el documento como parte constitutiva de la propia estrategia de Defensa argentina" (Alves, 2012: 235). De manera coherente con tales argumentos, posteriormente el Libro Blanco de la Defensa del año 2015, al referirse a los espacios de cooperación regional, señala que la dimensión internacional de la defensa está en armonía con los principios y valores que inspiran el ordenamiento interno y la política exterior argentina. $Y$ en el marco de tales principios, la política internacional de la defensa posee dos objetivos generales: "La promoción y consolidación de Suramérica como zona de paz y la progresiva construcción de un sistema subregional de Defensa" (Ministerio de Defensa de Argentina, 2015: 216). 
Igualmente, desde el punto de vista geoestratégico, la República Argentina buscaría desarrollar acciones de cooperación, complementación, intercambio y presencia, a través de un esquema de "círculos concéntricos", considerando el siguiente orden prioritario:

“-El espacio suramericano y el área del Atlántico Sur, incluyendo los espacios marítimos e insulares respectivos.

-El espacio latinoamericano y del Caribe.

-El marco global, con aquellos países de relevancia estratégica con los cuales en función de nuestros intereses en defensa existen oportunidades de complementariedad y cooperación. En este contexto se incrementarán especialmente las relaciones de Defensa en el marco de la cooperación Sur-Sur y con los países del Ilamado Grupo BRICS" (Ministerio de Defensa de Argentina, 2015: 220).

En dicho marco, América del Sur representaría el espacio prioritario de Argentina, con el objeto de concretar "la presencia institucional y las acciones de cooperación y complementación en materia de defensa, seguido sucesivamente del espacio latinoamericano y del Caribe, el continente americano y luego las regiones y actores relevantes para nuestros intereses nacionales en el resto del mundo" (Ministerio de Defensa de Argentina, 2015: 220).

Estando América del Sur en un lugar prioritario de la agenda exterior y de defensa de Argentina, este país ha buscado trabajar conjuntamente con otras naciones de la región en diversas instancias multilaterales y bilaterales, como son la MINUSTAH y últimamente la primera Misión Política Especial de Naciones Unidas en Colombia, cuyo mando estuvo a cargo del General argentino Javier Antonio Pérez de Aquino, como Jefe del componente militar de observadores. También cabe destacar, en tal sentido, las iniciativas conjuntas que Argentina ha llevado a cabo con Chile, particularmente con la Fuerza Conjunta Combinada Cruz del Sur y la Compañía de Ingenieros "Libertador don José de San Martín", junto a Perú. 
La mencionada cooperación es posible en un escenario propicio para ella. El Libro de la Defensa valora la existencia de una región pacífica, que desde la esfera de la defensa se caracteriza por la progresiva pérdida de relevancia de las percepciones de amenaza y las competencias estratégicas y militares. Ello, en un marco de respeto al derecho internacional y los principios de solución pacífica de controversias, "al tiempo que las políticas de defensa se orientan por el principio de legítima defensa y de concepciones y actitudes estratégicas de carácter defensivo y cooperativo" (Ministerio de Defensa de Argentina, 2015: 35). En este sentido, en una presentación realizada por el ex Canciller Héctor Timerman, en el marco del Ciclo de Debates para la Elaboración del Libro Blanco de la Defensa -el 10 de junio de 2014 en la Escuela de Defensa Nacional de Argentina- la autoridad planteaba que:

"Nuestra opción consciente y decidida es por un enfoque cooperativo. Este enfoque es el que ha permitido transformar a los vínculos bilaterales en materia de Defensa en una herramienta importante en la agenda positiva de las relaciones de la Argentina con terceros países" (En Ministerio de Defensa de Argentina, 2015: 32).

Esta orientación hacia la integración regional y la cooperación en el plano de la defensa, constituiría una prueba del abandono de los enfoques tradicionales basados en los supuestos geopolíticos vinculados con la Doctrina de Seguridad Nacional, basados en consideraciones de balance o proyección de poder e hipótesis de conflicto (DerGhougassian, 2012: 39), así como la recepción de concepciones renovadas sobre la seguridad y defensa, con un énfasis en la cooperación regional.

En la perspectiva de Buenos Aires, la defensa no se define, en consecuencia, a partir de la existencia o percepción de amenazas externas, ni se justifica meramente en términos de proyección de poder. De hecho, en el contexto de una región calificada como una Zona de Paz desde diversos países, instancias 
académicas e instituciones multilaterales, para Argentina, se requiere de una política de defensa proactiva hacia la cooperación,

"Primero, porque el giro estratégico de la integración regional que significó la creación de UNASUR y su CDS implica un importante rediseño de la arquitectura de la seguridad [y] Segundo, si bien la iniciática del CDS se originó en Brasil, la propuesta generó no sólo interés sino entusiasmo en la Argentina, donde se multiplicaron los debates públicos y la producción intelectual sobre el tema" (DerGhougassian, 2012: 39-40).

Sin perjuicio de lo anterior, es necesario aclarar que la opción argentina por impulsar la cooperación e integración regional en materia defensiva va de la mano de una fuerte crítica hacia el esquema hemisférico. De hecho, en diversas ocasiones el país ha impulsado el diálogo sobre este tema en el plano continental -particularmente en el contexto de los diálogos generados en la Conferencia de Ministros de Defensa de las Américas (CMDA)- promoviendo, por ejemplo, el reemplazo del TIAR por un nuevo Tratado Interamericano de Cooperación en Defensa, más acorde con las realidades actuales de la región y el mundo en materia de paz y seguridad.

La situación antes señalada ha llevado a Argentina a apoyar fuertemente las labores del Consejo de Defensa Suramericano, a fin de "consolidar un espacio regional caracterizado por acciones de defensa cooperativa", lo que "constituye un proceso superador de las maneras de relacionamiento en esta materia y los asuntos militares vigentes durante el siglo XX en el escenario interamericano, aunque aún se registra la supervivencia de instrumentos y organismos provenientes de un contexto internacional obsoleto, propio de la Guerra Fría" (Ministerio de Defensa de Argentina, 2015: 32). Así, para Argentina, la constitución del Consejo de Defensa, en el ámbito de la UNASUR:

“...significó un hito en dirección a los objetivos que inspiran a la política de Defensa argentina. Desde lo referido a la propia 
naturaleza del organismo regional -una instancia de consulta, cooperación y coordinación en materia de Defensa- hasta cada uno de sus principios generales y objetivos particulares, la totalidad refleja los postulados y la concepción estratégica a partir de los cuales el país se posiciona en la región y en el mundo" (Ministerio de Defensa de Argentina, 2015: 221).

De este modo, al igual que Brasil, Chile y Ecuador, Argentina asumirá aquellos principios del Consejo, orientados a la constitución de un órgano flexible de consulta y coordinación en materia defensiva, basado en los consensos regionales. En los hechos, este último país ha trabajado, desde la constitución del organismo, en la ejecución de lo dispuesto en su estatuto y en sus planes de acción, "lográndose una consolidación progresiva y creciente de mayores niveles de diálogo y confianza mutua entre todos los países de la región" (Ministerio de Defensa de Argentina, 2015: 224).

Considerando lo anterior, entre las prioridades temáticas de Argentina en el Consejo de Defensa, destaca su interés por el ámbito de la formación y capacitación, como lo demuestran las diversas actividades que contemplan los planes de acción anuales del Consejo en esta materia, donde Argentina aparece con el mayor perfil al respecto. En la práctica, según señalan Sanahuja y VerdesMontenegro, desde 2010 cuatro de cada diez actividades programadas en los planes anuales han sido asumidas por este país. Además, a juicio de tales autores, junto con proyectarse como un mecanismo de proyección política, el interés que ha mostrado Argentina en el eje de formación y capacitación, así como los recursos que ha destinado a su desarrollo, bien podrían interpretarse "como un medio de reequilibrar su capacidad militar frente a Brasil, a través de un mecanismo de poder blando en un momento clave de definición y configuración del pensamiento estratégico regional" (Sanahuja y Verdes-Montenegro, 2014: 517).

Junto a ello, también ha estado entre las prioridades de Argentina el impulso de un pensamiento estratégico regional, como lo indica el que haya promovido fuertemente la creación del CEED, con su sede en Buenos Aires, así como el que 
su primer Director, haya sido el ex Secretario de Estrategia y Asuntos Militares, Alfredo Forti.

Cabe destacar que la mirada argentina sobre la seguridad regional ha influido fuertemente en las labores del CEED, como se aprecia en los diversos estudios y documentos elaborados por dicho centro, que se concentran en temas como la relación entre la defensa y los recursos naturales estratégicos, enfoque muy cercano a las prioridades argentinas en materia de defensa, particularmente en su apreciación sobre el resguardo de su posición en el Atlántico Sur, incluyendo el tema de las Islas Malvinas.

En esta línea, a instancias de Argentina, en 2014 se celebraría en ese país, como parte del plan de acción de ese año, una Conferencia sobre Defensa y Recursos Naturales y un seminario regional sobre otro tema relevante para este país, cual es la ciberdefensa en el marco de la UNASUR. Relacionado con lo anterior, en el marco del Grupo de Trabajo sobre Defensa y Recursos Naturales, en el Plan de Acción 2016 Argentina aparece liderando, junto a Ecuador, una iniciativa destinada a avanzar en la elaboración del inventario de los recursos naturales estratégicos de la región, en coordinación con el CEED. ${ }^{85}$ También destaca el papel protagónico jugado por el país, junto a Brasil, en la construcción de aviones de entrenamiento (UNASUR I) y no tripulados, como parte del eje relacionado con la industria de la defensa regional.

Sin perjuicio de lo anterior, es necesario aclarar que el apoyo de Argentina al Consejo de Defensa Suramericano podría verse afectado, considerando el reciente anuncio del gobierno de ese país de estar evaluando su participación en la UNASUR. Aunque al momento en que se escriben estas líneas el tema aún se encuentra en análisis en Argentina.

${ }^{85}$ El Plan de Acción 2016 se encuentra disponible en http://ceed.unasursg.org/Espanol/09Downloads/Esp-PA/PA-CDS-2016.pdf Recuperado en diciembre de 2017. 


\section{8.- Conclusiones}

Como se explicaba al inicio de esta tesis doctoral, el fin de la Guerra Fría trajo aparejado una reconfiguración del poder mundial, dándose término al sistema internacional bipolar que dominó el mundo durante gran parte del siglo $\mathrm{XX}$, en cuyo lugar se constituyó un contexto transitoriamente unipolar, dominado por Estados Unidos, pero que rápidamente comenzó a demostrar relevantes características de multipolaridad. De manera tal, paulatinamente comenzó a apreciarse una transformación de la política y la economía globales, donde países de la tradicionalmente denominada periferia, comenzaron a adquirir un relevante papel, como partes del mundo emergente.

Este proceso ha sido particularmente visible en Asia, con el auge demostrado por China e India, pero también es notorio en otras regiones del mundo, como es el caso de Brasil en América del Sur y Sudáfrica en el continente africano. Al decir de Zbigniew Brzezinski, estamos en presencia de una "era posthegemónica", determinada por el desarrollo de nuevos polos de poder político y económico, donde ningún actor internacional posee la capacidad de imponer plenamente su voluntad a los demás.

Este nuevo contexto global se caracteriza también por la progresiva relevancia de los bloques regionales, de las instituciones multilaterales, así como de una serie de actores no estatales, como es el caso de las ONGs, las empresas multinacionales e incluso las cada vez más extensas redes del crimen organizado y el terrorismo. En consecuencia, se asiste a un nuevo escenario descentralizado, fundamentalmente distinto al escenario interestatal delineado a partir de la Paz de Westfalia, donde los Estados, para acomodarse a estas nuevas circunstancias y mantener atributos de influencia en el marco internacional, han debido -sino por opción, al menos por necesidad- aumentar la cooperación, muchas veces de la mano de procesos de integración regional.

O sea, en un contexto global donde los Estados no pueden por sí mismos garantizar y satisfacer las necesidades de bienestar de sus poblaciones, como ha sido visible en los temas de seguridad y defensa, aquellos se han embarcado en mecanismos de acción más amplios. En el fondo, a lo que se apunta es que, en tal 
contexto, los Estados -particularmente los más pequeños- han apreciado que sus posibilidades de incidir de manera autónoma en la toma de decisiones sobre los grandes sucesos de la política mundial y de satisfacer de mejor manera sus necesidades domésticas, se incrementan en la medida que pueden actuar de manera concertada y colectiva, en el marco de instancias de cooperación e integración.

Es decir, la desconcentración del poderío mundial ha ido de la mano del creciente desarrollo de procesos de integración en diversas regiones del orbe, por cuanto ante las dificultades que han encontrado los mecanismos internacionales de gobernanza global, los instrumentos regionales y subregionales han servido como una instancia más efectiva para dotar de coherencia y estabilidad las relaciones entre los países.

La relación entre integración y seguridad, que está presente desde los orígenes de la Teoría de la Integración, forma parte esencial del marco conceptual que guía esta investigación. Según este cuerpo teórico, la interdependencia que genera un proceso integrativo se expresa en la institucionalización de las relaciones entre los actores y la generación de objetivos e intereses cruzados, lo que incrementa la confianza entre los mismos $\mathrm{y}$, consecuentemente, baja los costos de las transacciones y las comunicaciones, favoreciendo la predictibilidad de las conductas, lo que minimiza los riesgos de enfrentamiento.

En el ámbito de la integración en América del Sur, un especial impulso se dio desde mediados de la década de los ochenta, en el marco de los procesos de transición a la democracia que vivieron variados países de la región, y sobre todo a partir de la década de los noventa, donde destaca la creación del MERCOSUR el año 1991, bajo el liderazgo argentino-brasileño. A partir de ese momento, es posible señalar que desde el Cono Sur se derramó a la región en su conjunto, un dinámico proceso de configuración de un espacio susceptible de caracterizar como de "paz positiva", con la progresiva conformación de una comunidad pluralista de seguridad, donde se hace improbable la solución de los conflictos internacionales mediante el uso de la fuerza.

En general, este trabajo se guió por el argumento fundamental de que ha sido en el ámbito estratégico donde se exhibirían los mayores avances de la integración 
regional, más allá de sus aspectos económicos y comerciales, lo que constituiría un singular aporte de América del Sur a la teorización sobre la integración regional, al momento de reflexionar sobre las relaciones internacionales del mundo contemporáneo.

Bajo estos supuestos es que el año 2008 los países sudamericanos, con el impulso de Brasil -constructor prominente de América del Sur como foco político y conceptual-, constituyeron el Consejo de Defensa Suramericano, con el objeto de consolidar a la región como una Zona de Paz, capaz de contribuir constructivamente a la gobernanza global, favoreciendo, al mismo tiempo, la eventual formación de una identidad regional en materia de defensa y producir consensos para fortalecer la cooperación regional en estas temáticas. Pensado desde Brasil, el objetivo de impulsar el Consejo otorgaría a este país una mayor legitimidad a su pretensión de ocupar un asiento permanente en el Consejo de Seguridad de Naciones Unidas y, a su vez, permitiría a la región enfrentar los temas de defensa con una perspectiva regional, dejando a un lado la histórica influencia norteamericana en la zona. Aunque cabe recalcar que el liderazgo brasileño no ha sido constante en el plano regional, no contando tampoco con el unánime apoyo de los demás países de la región.

El Consejo de Defensa buscaría colaborar en el tratamiento de los desafíos de defensa de la región bajo una perspectiva propiamente sudamericana, poniendo énfasis en la relación positiva que se expresa en la relación entre integración y seguridad regional. Con estos avances, es claro que los países sudamericanos, si bien aún mantienen diferencias y roces, han paulatinamente abandonado el uso de la fuerza como un mecanismo de solución de las controversias entre ellos, observándose la presencia de una comunidad pluralista de seguridad, en los términos de Karl Deutsch, a nivel regional sudamericano. En tal sentido, como se ha planteado en este trabajo, la presencia de una comunidad de seguridad regional no implica la ausencia de conflictos, los que pueden acontecer en toda realidad social donde existen interacciones, sino que las diferencias que se susciten serán tratadas de manera racional e institucionalmente.

Como un proceso íntimamente vinculado con la generación de nuevas lealtades y sentidos colectivos de comunidad política, la existencia de una comunidad 
pluralista de seguridad involucra el que los países que forman parte de ella, han pasado a asumir que los Estados próximos no sólo representan una fuente de inseguridad, sino que, lo más importante, forman parte esencial de las soluciones. O sea, la seguridad de los Estados ya no se concibe como un juego de suma cero, sino como una tarea conjunta e interdependiente, que se alcanza de manera cooperativa.

Sin perjuicio de lo antes señalado, es relevante plantear que la integración regional ha seguido un camino sinuoso. Las perspectivas pesimistas sobre dicho proceso no carecen de fundamento, en tanto la integración regional ha presentado numerosos obstáculos y tropiezos. Entre ellos se encuentra la carencia de un líder constante y sostenido que conduzca el proceso integrativo, aunque por sus dimensiones y prestigio, Brasil parece tener las mayores posibilidades para incidir en esta materia. Sin embargo, el coloso sudamericano no ha manifestado impulsos constantes por configurarse como líder regional, así como no ha contado con el unísono apoyo de los demás actores regionales (Malamud, 2011), algunos de los cuales lo perciben como un país más preocupado en fortalecer su posicionamiento internacional -donde la máxima meta es alcanzar un asiento permanente en el Consejo de Seguridad de Naciones Unidas- que de contribuir de manera sustancial ante los grandes desafíos que debe enfrentar la región de América del Sur.

Junto con lo anterior, cabe recalcar también las complejas tareas pendientes que expresa la región en materia de consolidación democrática, con la aparición de variados líderes con discursos nacionalistas, que en variadas ocasiones han generado inestabilidades en las relaciones entre los países, militarizando conflictos. Aunque ello no se constituye como óbice para la valoración de América del Sur como una región donde predomina la paz entre los Estados, siendo posible caracterizarla como una Zona de Paz, desde la perspectiva de los conflictos interestatales, libre de armas de destrucción masiva y con el menor gasto en defensa en el mundo. En consecuencia, la región sería un buen ejemplo de la positiva correlación existente entre democracia y paz.

Ello, sin perjuicio de otros desafíos que aún mantiene la región, particularmente bajo el prisma de la seguridad ciudadana, siendo América Latina, en general, una 
de las regiones más violentas del mundo, con un alto desarrollo del crimen organizado. Esta situación nos ha llevado a definir a la región como una Zona de Paz Violenta. Es decir, pacífica desde el punto de vista interestatal, pero muy conflictiva en lo relacionado con los índices de seguridad pública y ciudadana.

En el marco antes descrito, el desarrollo del Consejo de Defensa Suramericano contó con distintos antecedentes, como son las numerosas impugnaciones planteadas sobre el denominado sistema hemisférico, como un esquema anacrónico, poco operativo y meramente dependiente de los lineamientos de Washington. Tal situación llevó a los países a inclinarse por avanzar en esquemas subregionales, donde era más fácil encontrar preocupaciones e intereses comunes. En virtud de lo anterior, se explicaron los relevantes avances que se materializaron en el plano de la seguridad y la defensa en el contexto del MERCOSUR y la CAN, donde se acordaron declaraciones de zonas de paz, que se constituyeron en la base para el posterior avance a nivel regional. En suma, los esfuerzos de la UNASUR, en el plano de la defensa, vinieron a sumar los esfuerzos subregionales del Cono Sur y la zona andina, particularmente del primero.

Operativamente, desde los inicios del año 2008 Brasil comenzó a proponer la idea de crear un Consejo de Defensa Suramericano, como consejo sectorial de la UNASUR, con el objeto de constituir un foro regional flexible de consulta, cooperación y coordinación en materias de defensa. Bajo el influjo de Brasil, y contando también con el firme apoyo de Chile y Ecuador, el Consejo de Defensa se instaló como un mecanismo liviano desde el punto de vista institucional, sin pretender alcanzar una mayor densidad. Es decir, el Consejo fue promovido desde un principio como un foro de diálogo, representando una forma pragmática de repensar el fuertemente criticado sistema interamericano de seguridad y defensa, pero sin pretender configurar un denso mecanismo institucional de seguridad colectiva, a la manera de la OTAN. Aunque esta es una temática todavía en discusión en América del Sur.

Teniendo como guía estos moderados objetivos, dicho organismo regional se ha constituido, en la práctica, en un valioso mecanismo de diálogo y cooperación, que 
ha generado confianza entre los miembros y previsibilidad en las conductas, atenuando las incertidumbres y reforzando la estabilidad entre sus miembros.

En suma, ha expresado de manera preclara el desarrollo paulatino pero creciente de la señalada comunidad pluralista de seguridad a nivel sudamericano, en tanto de manera predominante y mayoritaria, los países de la región están tan vinculados entre sí y preocupados de su inserción internacional, que las expectativas de los costos de un enfrentamiento armado superan los beneficios. Además, actualmente las políticas de defensa se caracterizan por sus importantes rasgos cooperativos, dejando en un plano secundario a la tradicional disuasión y a la lógica geopolítica. Para tales Estados, la existencia de un entorno de paz y estabilidad es funcional a sus intereses y objetivos.

En último término, el Consejo forma parte de un proceso multidimensional de integración, que busca consolidar a la región como una Zona de Paz, sin hegemonías, orientado por la idea central de alcanzar la autonomía estratégica de América del Sur y su inserción en el contexto multipolar global, donde cabe destacar la creación del Centro de Estudios Estratégicos de Defensa (CEED) y la Escuela Suramericana de Defensa (ESUDE), con el objeto de avanzar hacia un pensamiento estratégico propiamente regional.

Junto con ello, y atendida la situación de que los desafíos y amenazas actuales hacen cada vez más borrosa la distinción entre los temas de defensa y seguridad, así como entre los temas civiles y militares, será relevante que el Consejo de Defensa apuntale sus relaciones con otros consejos sectoriales de la UNASUR, como son aquellos encargados de los temas de Ciencia, Tecnología e Innovación; Infraestructura y Planeamiento; Seguridad Ciudadana, Justicia y Coordinación contra la Delincuencia Organizada Transnacional; y Problema Mundial de las Drogas. Los complejos desafíos que debe enfrentar la región en la actualidad exigen de una labor coordinada e interagencial en los planos nacional e internacional. Esta es una temática que puede abrir nuevas perspectivas para futuros estudios.

Un espacio que se vislumbra como fundamental para cimentar los principios de una eventual defensa común sería en el área de la protección de los recursos naturales. Una mirada estratégica y auténticamente sudamericana en torno al 
desafío de resguardar estas riquezas será esencial para el futuro de la integración en defensa y para situar a Sudamérica con una voz propia en el diversificado escenario internacional que se está configurando. Reforzar con pragmatismo las estructuras de integración en el ámbito de la defensa puede ser un importante aporte a este nuevo contexto en formación. El éxito en este impulso requiere de voluntad y unificación de los esfuerzos.

El que América del Sur avance hacia una comunidad de seguridad madura, como es el caso de la Unión Europea, donde los países miembros no albergan mutuas hipótesis de conflicto y dirigen sus preocupaciones hacia el entorno extrarregional adyacente, dependerá de que los países dejen de considerar a los vecinos y otros actores del entorno como potenciales amenazas, desactivando definitivamente los factores disuasivos que perviven en las respectivas políticas de defensa en pos de la plena cooperación. Los avances bilaterales que se aprecian en las relaciones entre Chile y Argentina pueden constituirse como un antecedente relevante para seguir avanzando en el terreno multilateral, que se constituye como una condición básica de inserción global, que promueve reglas claras y transparentes para cada uno de los actores internacionales, particularmente para los de menor tamaño relativo, como es el caso de la mayoría de los países sudamericanos.

La participación de los países en el Consejo ha favorecido la confianza mutua con el entorno vecinal y regional, apuntalando un entramado de intereses conexos de desarrollo y paz, lo que ha permitido abandonar definitivamente el recurso a la guerra como medio de solución de los conflictos, siendo la cooperación en defensa un elemento funcional con la pretensión de favorecer una región estable y segura. Ello resulta particularmente coherente con los intereses de desarrollo de los países de la región, que requieren de un ambiente regional e internacional seguro, de manera de poder disfrutar los "dividendos de la paz".

Nuevas investigaciones podrían indagar igualmente en las tendencias institucionales de la UNASUR y el Consejo de Defensa Suramericano, a fin de sugerir nuevos desarrollos en este ámbito. Con el objeto de contribuir a la inserción política internacional de América del Sur, un camino a seguir podría ser evaluar el establecimiento de una política de defensa a nivel regional, lo que requiere, desde luego, avanzar en lineamientos comunes en el campo de la 
política exterior y de seguridad, como ha sido el recorrido que ha seguido la Unión Europea. Un desempeño exitoso en este sentido debiera desembocar, en el largo plazo, también en el establecimiento y despliegue de fuerzas y misiones regionales en el exterior. Esta senda sería coherente con los impulsos que está dando Naciones Unidas al respecto, atendido el relevante papel que pueden cumplir los organismos regionales en materia de paz y seguridad internacionales.

Esta investigación se asumió bajo el prisma de la Teoría de la Integración, la que tiene afinidad con el paradigma institucionalista liberal y el constructivismo. Bajo tales perspectivas, el contexto regional y global se caracteriza por la cooperación entre los diversos actores estatales y no estatales, en el marco de relaciones internacionales determinadas por el desarrollo y complejidad que alcanzan las instituciones multilaterales, que se orientan a la regulación de la convivencia entre los actores de la sociedad internacional, con efectos trascedentes sobre la conducta de los Estados.

De este modo, el comportamiento exterior de los entes estatales se hace cada vez más predecible y estable, así como cooperativo en torno al enfrentamiento de problemas comunes, superando el clásico esquema hobbesiano, caracterizado por la constante lucha por la propia seguridad nacional.

Con ciertos vaivenes, este ha sido el esquema bajo el cual se ha movido hasta ahora el escenario internacional, lo que es particularmente visible en el caso europeo y latinoamericano, aunque las últimas tendencias que evidencia la política mundial parecen tomar un camino inverso, como lo demuestra la compleja situación del Medio Oriente, particularmente Siria; el comportamiento exterior de Corea del Norte, que tiene al mundo sumido en un continuo ataque de nervios ante la permanente amenaza de hacer uso de armas de destrucción masiva; así como la conducta exterior que exhibe la nueva política exterior de Estados Unidos, articulada por el gobierno de Donald Trump.

Ciertamente, el factor Trump ha tenido relevantes efectos en el plano internacional, sobre la base de un giro radical en la política exterior de la gran potencia militar del mundo, luego de la moderación exhibida por la diplomacia del gobierno demócrata de Barack Obama. Éste último, luego de las graves convulsiones mundiales generadas por la guerra de Irak y la política exterior 
acentuadamente unilateral puesta en marcha por la anterior administración de George W. Bush y su Cowboy Diplomacy, había procurado poner un mayor acento en el multilateralismo, moderando las antiguas tendencias hegemónicas de la administración conservadora anterior, lo que se expresó, por ejemplo, en una activa labor en organismos multilaterales y en un cierto distanciamiento de la postura israelí respecto de la denominada cuestión palestina, frenando aquellas tendencias que se inclinaban hacia el choque de civilizaciones.

Pero esta tendencia moderadora de la política exterior americana, con el nuevo inquilino de la Casa Blanca, ha entrado en un franco retroceso, ante lo cual América del Sur no puede adoptar una conducta pasiva y tomar palco, en un contexto global que tiende al multipolarismo en variadas esferas. Tal escenario requiere de una comprometida y autónoma participación de la región en los sucesos políticos globales, favoreciendo un entorno político global donde prime el multilateralismo. Ello resulta especialmente necesario ante la conducta internacional del Estados Unidos de Donald Trump que, en el plano de la política exterior, pareciera oscilar entre dos tendencias que parecen incongruentes: el aislacionismo por un lado, o el intervencionismo o policía mundial, por el otro. Ello, contextualizado en un mundo que, desde diversos sectores, se ha planteado que estaría entrando en una "Nueva Guerra Fría", donde también Rusia está buscando recuperar su antiguo status de superpotencia.

Como una Zona de Paz, América del Sur puede representar un singular ejemplo y agente estabilizador ante un contexto mundial que parece caminar hacia el desfiladero, dándole muchas veces la razón a los supuestos más pesimistas del Realismo. Este contexto histórico exige una actividad conjunta de América del Sur en la política mundial, promoviendo un renovado marco internacional donde prime el multilateralismo. Ello exige avanzar en posiciones comunes ante variadas materias, particularmente en el plano de la paz y seguridad internacionales, un pilar fundamental del sistema de Naciones Unidas. Si la región quiere tener una voz en el mundo actual, no puede adoptar una posición pasiva y fragmentada. Al momento en que se escriben estas líneas, la realidad regional tampoco parece la más auspiciosa, con el anuncio venezolano de retirarse de la OEA, acusándola de intervencionismo. Para lo anterior, es imprescindible que la región avance hacia la 
consolidación de su condición de comunidad de seguridad, en pos de avanzar hacia un estado de madurez donde los miembros de la región abandonen definitivamente la mutua disuasión y asuman colectivamente los nuevos roles que le exige el mundo, tal cual lo ha venido haciendo la Unión Europea.

Desde luego, lo anterior exige como condición básica el fortalecimiento de la democracia y el Estado de Derecho. Las turbulencias que se presentan actualmente en la región están relacionadas directamente con la existencia de líderes populistas que, buscando apoyo político interno, no trepidan en buscar enemigos externos, para lo cual tampoco dudan en poner en marcha intensos procesos de movilización de la opinión pública, contando usualmente con el apoyo de la prensa.

Para que América del Sur se constituya como una comunidad de seguridad madura es necesario, en suma, avanzar en el desarrollo de sociedades plenamente abiertas y plurales, que se constituyan como la base de un comportamiento internacional estable y cooperativo, que propenda a un proceso paulatino pero creciente de institucionalización de este complejo de seguridad regional que, al tiempo que fortalezca y densifique sus estructuras, no pierda la flexibilidad que necesita una región tan diversa como lo es América del Sur.

En el fondo, los países sudamericanos deben abandonar las nociones más tradicionales que aún perviven en ciertos ámbitos de las políticas de defensa para, de la mano de la política exterior, proyectar sus preocupaciones desde el vecindario hacia el mundo. La interdependencia requiere visiones globales, y las políticas de defensa no pueden sustraerse de esta situación. Sólo de este modo la región podrá construir más efectivamente un mundo más estable y seguro, así como coherente con sus intereses de bienestar y desarrollo. 


\section{9.- Bibliografía}

-Adler, E. (2001). "The change of change: Peaceful transitions of power in the multilateral age". En Kupchan, C.; Adler, E.; Coicaud, J.; y Foong Khong, Y. (eds.), Power in Transition. The peaceful change of international order. Tokio: United Nations University Press.

-Alda, S. (2012a). "El espacio militar en el ALBA". En Alda, S. y Gómez, V. (Eds.). El concepto y las relaciones multilaterales de seguridad y defensa en el contexto de la UNASUR. Quito: UNED-Ministerio de Defensa Nacional de Ecuador.

-Alda, S. (2012b). "El ALBA y su propuesta de integración militar". En Alda, S. y Saint-Pierre, H. (Coords.). Gobernabilidad y democracia. Defensa y transiciones de Brasil y España. Santiago de Chile: RIL Editores.

-Álvarez, D. (2004). "Fuerzas Armadas en Chile: entre la configuración de nuevos roles y la normalización de las relaciones cívico-militares". Buenos Aires: CLACSO. Disponible en http://biblioteca.clacso.edu.ar/clacso/becas/20101115100812/alvarez.pdf Recuperado en septiembre de 2015.

-Alves, S. (2012). "Las percepciones sobre amenazas y cooperación en la política de defensa de Argentina, Brasil y Chile en la década de 1990". En Alda, S. y SaintPierre, H. (Coords.). Gobernabilidad y democracia. Defensa y transiciones de Brasil y España. Santiago de Chile: RIL Editores.

-Ambrose, S. (1997). "War in the Twenty-First Century". En Ambose. S. Americans at War. Jackson: University Press of Mississippi.

-Amorim, C. (2012). "Estrategia de Defensa de Brasil y de América del Sur". Revista de Ciencia Política, No 32.

-Aranda, G. (2013). El proyecto Chávez (1999-2007): Participación, isocracia e integración regional. Santiago de Chile: Editorial Universitaria.

-Aranda, G. y Riquelme, J. (2014). "Es posible la convergencia en la diversidad? Chile entre la Alianza del Pacífico y el MERCOSUR". Revista de Relaciones Internacionales, Estrategia y Seguridad, Vol. 10, № 2.

-Aranda, G.; Riquelme, J. y Salinas, S. (2015). "La ciberdefensa como parte de la agenda de integración sudamericana”. Línea Sur, $N^{\circ} 9$.

-Arce, M. (2010). "Escenario regional sudamericano". Memorial del Ejército de Chile, $\mathrm{N}^{\circ} 484$.

-Arredondo, R. (2014). "La Responsabilidad deProteger: la perspectiva latinoamericana". Araucaria. Revista Iberoamericana de Filosofía, Política y Humanidades, Vol. 32, N¹6. 
-Atria, Rodrigo. (2009). "Chile y su defensa. Transformaciones y desafíos". Política y Estrategia, $\mathrm{N}^{\circ} 113$.

-Bachelet, M. (2013). Programa de Gobierno Michelle Bachelet 2014-2018. Disponible en http://www.minsegpres.gob.cl/wpcontent/upLoads/2014/04/ProgramaMB.pdf Recuperado en septiembre de 2014.

-Bárcena, M. (2000). "La reconceptualización de la seguridad: el debate contemporáneo". Revista Mexicana de Política Exterior, № 59.

-Barroso, F. (2016). “¿Existe una comunidad de seguridad sudamericana?”. Política y Estrategia, N¹27.

-Bartolomé, M. (2009). "Las Fuerzas Armadas sudamericanas y las perspectivas de cooperación en la lucha contra el terrorismo y el crimen organizado". Estudios Internacionales, $\mathrm{N}^{\circ} 164$.

-Battaglino, J. (2012). "Democracia, reconfiguración de amenazas y la paz sudamericana". Iconos. Revista de Ciencias Sociales. № 51.

-Bauman, Z. (2007). Tiempos líquidos. Vivir en una época de incertidumbre. Barcelona: Tusquets Editores.

-Bergsten, F. (1996). "Globalizing free trade: the ascent of regionalism". En Foreign Affairs. May-June.

-Bertonha, J. (2010). "Brazil: an emerging military power? The problem of the use of force in Brazilian international relations in the 21st century". Revista Brasileira de Política Internacional, Vol. 53, № 2.

-Bielschowski, R. (2009). "Sesenta años de la CEPAL: estructuralismo y neoestructuralismo". Revista de la CEPAL. N 97.

-Binnendijk, H. y Kugler, R. (2006). Seeing the elephant. The U.S. role in global security. Washington D.C.: National Defense University.

-Bizzozero, L. (2011). "Aportes del MERCOSUR al regionalismo y a la teoría política de la integración regional. Una mirada desde los veinte años del proceso", Boletín Meridiano, №47.

-Bonilla, A. (2010). "La política andina de los Estados Unidos y el conflicto colombiano en la seguridad del Ecuador". En Loveman, B. (ed.). Adictos al fracaso: políticas de seguridad de Estados Unidos en América Latina y la región andina. Santiago de Chile: Lom Ediciones.

-Botto, M. (2015). La integración regional en América Latina: Quo Vadis?. Buenos Aires: EUDEBA. 
-Briceño, J. (2013). "Ejes y modelos en la etapa actual de la integración económica regional de América Latina”, Estudios Internacionales, Nº 175.

-Brum, P. y Burgoyne, M. (2017). "Securing the Future by Looking South: Strategic Oppotunities for the United States in Latin America". Regional Insights, N 4.

-Bruneau, T. (2005). "Civil-Military Relations in Latin America: The Hedgehog and the Fox Revisited". Revista Fuerzas Armadas y Sociedad, Año 19, № 1-2.

-Burgos, J. (2014). "La mejor forma de construir una cultura de paz es con más democracia". Patria. Análisis Político de la Defensa, № 3.

-Buzan, B. y Wæver, O. (2003). Regions and Powers. The Structure of International Security. Cambridge: Cambridge University Press.

-Buzan, B. (2009). People, States \& Fear. Colchester: ECPR Press.

-Calduch, R. (1993). Dinámica de la sociedad internacional. Madrid: Ceura. Disponible en http://pendientedemigracion.ucm.es/info/sdrelint/lib2cap8.pdf Recuperado en mayo de 2014.

-Calle, M. (2014). "El fin del TIAR y el inicio de la reconfiguración geopolítica de Suramérica". Patria, № 2.

-CEED, Centro de Estudios Estratégicos de Defensa (2014). La defensa y los recursos naturales en Suramérica. Aportes para una Estrategia Regional. Buenos Aires: Centro de Estudios Estratégicos de Defensa. Disponible en http://ceed.unasursg.org/Espanol/09-Downloads/Biblioteca/DEF-RRNN.pdf

-CEED, Centro de Estudios Estratégicos de Defensa (2017). Registro Suramericano de Gastos Agregados en Defensa 2006-2015. Buenos Aires: Centro de Estudios Estratégicos de Defensa. Disponible en http://ceed.unasursg.org/Espanol/09-Downloads/Biblioteca/RSGAD-2006-2015WEB.pdf Recuperado en diciembre de 2017.

-Celi, P. (2007). "Integración y seguridad en un nuevo regionalismo". En Atlas comparativo de la defensa en América Latina. Buenos Aires: RESDAL-SER.

-Celi, P. (2012). "La seguridad regional en el nuevo multilateralismo suramericano". En Alda, S. y Gómez, V. (Eds.). El concepto y las relaciones multilaterales de seguridad y defensa en el contexto de la UNASUR. Quito: UNEDMinisterio de Defensa Nacional de Ecuador.

-CEPAL. (1994). El regionalismo abierto en América Latina y el Caribe: la integración económica al servicio de la transformación productiva con equidad. Santiago de Chile: CEPAL. 
-Colacrai, M. y Lorenzini, M. (2005). "La política exterior de Chile: ¿excepcionalidad o continuidad? Una lectura combinada de "fuerzas profundas" y tendencias". Confines, $\mathrm{N}^{\circ} 1 / 2$.

-Comini, N. (2010). "El rol del Consejo de Defensa de la UNASUR en los últimos conflictos regionales". Nueva Sociedad, No 230.

-Comini, N. (2015). "El origen del Consejo de Defensa Suramericano. Modelos en pugna desde una perspectiva argentina", Revista de Estudios en Seguridad Internacional, Vol. 1, No. 2

-Conniff, M. (2003). “Neo-populismo en América Latina. La década de los noventa y después". Revista de Ciencia Política. Vol. 23, №1.

-Corbo, V. (1988). "Problemas, Teoría del Desarrollo y Estrategias en América Latina”. Estudios Públicos. N 32.

-Crahan, M. (1982). "National security ideology and human rights". En Crahan, M (ed.). Human rights and basic needs in the Americas. Washington D. C.: Georgetown University Press.

-Cubel, F. (2016). "El Estado de la seguridad en América Latina 2015". Documento de Opinión, Instituto Español de Estudios Estratégicos, Nº1/2016.

-Dammert, L. (2012). “¿Más pacíficos pero más violentos?: breve análisis del Índice de Paz Mundial”. Escenarios Actuales. Año 17, №3.

-D'Araujo, M. (2013). "Matices de las visiones sobre militares y sociedad en América del Sur". Documentos CIDOB América Latina, N³6.

-Da Silva, F. (2012). "Política de defesa e segurança do Brasil no século XXI: un esboço histórico". En Filho, E. y De Moraes, R. Defesa nacional para o século XXI. Rio de Janeiro: IPEA.

- Da Silva, L. y Lagos, R. (2014). “América Latina: dos océanos, una voz”. En El País (España), 19 de junio. Disponible en http://elpais.com/elpais/2014/06/11/opinion/1402515021 275792.html

Recuperado en junio de 2014.

-De Ayala, J. (2012). "La Política Común de Seguridad y Defensa de la Unión Europea”. En Alda, S. y Saint-Pierre, H. (Coords.). Gobernabilidad y democracia. Defensa y transiciones de Brasil y España. Santiago de Chile: RIL Editores.

-Del Arenal, C. (1993) "El nuevo escenario mundial y la teoría de las Relaciones Internacionales". En Abellán, V. y Pérez, M. Hacia un nuevo orden internacional y europeo: estudios en homenaje al profesor Manuel Diez de Velasco. Madrid: Tecnos. 
-Del Arenal, C. (2003). Introducción a las relaciones internacionales. Madrid: Tecnos.

-De la Torre, C. y Arnson, C. (2013). "Introduction: The Evolution of Latin American Populism and Debates over its Meaning". En De la Torre, C. y Arnson, C. Latin American populism in the twenty-first century. Washington D.C. : Woodrow Wilson Center Press.

-DerGhougassian, K. (2011). "Towards the Citizenization of the Armed Forces". En Moreyra, M. Defense Policy in Latin America. Ginebra: Geneva Centre for the Democratic Control of Armed Forces.

-DerGhougassian, K. (2012). "Evolución de la política de defensa". En DerGhougassian, K. (coord.), La defensa en el siglo XXI. Argentina y la seguridad regional. Buenos Aires: Capital Intelectual.

-De Sousa, S. (2007). "La India, el Brasil y Sudáfrica: ¿potencias emergentes o países en desarrollo?". El Debate Político. Revista Iberoamericana de Análisis Político. Año 4, N6/7.

-Deutsch, K. (1974). El análisis de las relaciones internacionales. Buenos Aires: Paidós.

-Diamint, R. (1999). "Integración y seguridad. La dialéctica de los actores argentinos". En Rojas, F. (ed.). Argentina, Brasil y Chile: Integración y Seguridad. Caracas: Flacso-Editorial Nueva Sociedad.

-Dougherty, J. y Pfaltzgraff, R. (1993). Teorías en pugna en las Relaciones Internacionales. Buenos Aires: Grupo Editor Latinoamericano.

-Doyle, M. (1983). "Kant, liberal legacies, and foreign affairs". Philosophy and Public Affairs, $\mathrm{N}^{\circ} 12$.

-Einaudi, L. (2011). "Brazil and the United States: The Need for Strategic Engagement". Strategic Forum, $\mathrm{N}^{\circ} 266$.

-Espinoza, M. (2013). "Tenemos una voz de paz en el escenario global". Patria. Análisis Político de la Defensa, № 1.

-Farah, D. (2016). "Convergence in Criminalized States: The New Paradigm". En Matfess, H. y Miklaucic, M. Beyond convergence. World without order. Washington D.C.: National Defense University.

-Fernández, M. (2010). "América Latina: su integración, prioridad en la Política Exterior de Chile. En Ministerio de Relaciones Exteriores de Chile. El mundo desde el sur. Voces de Chile en Política Exterior. Santiago de Chile: Gobierno de Chile. 
-FLACSO. (2010). Estudio de Opinión Pública en Latinoamérica 2009-2010. Gobernabilidad y Convivencia Democrática en América Latina. San José de Costa Rica: FLACSO.

-Flemes, D. (2004). "Institution building in MERCOSUL's defence- and security sector (I). Brazil's defence cooperation: between dominant armed services and marked bilateralism". Arbeitspapiere des IKK, $\mathrm{N}^{\circ} 20$.

-Flemes, D. ; Nolte, D.; y Wehner, L. (2011). "Una comunidad de seguridad regional en formación: la UNASUR y su Consejo de Defensa". Estudios Internacionales, $\mathrm{N}^{\circ} 170$.

-Flemes, D. y Radseck, M. (2009). "Creating Multilevel Security Governance in South America". GIGA Working Papers, $\mathrm{N}^{\circ}$ 117. Disponible en https://papers.ssrn.com/sol3/papers.cfm?abstract id=1534591 Recuperado en marzo 2015.

-Flisfisch, A. (2010). "Las razones del compromiso de Chile con UNASUR". En Ministerio de Relaciones Exteriores de Chile. El mundo desde el Sur. Voces de Chile en política exterior. Santiago de Chile: Gobierno de Chile.

-Flisfisch, A. y Robledo, M. (2012). Gobernabilidad democrática de la defensa en Chile: un índice para el período 1990-2010. Santiago de Chile: PNUD.

-Forti, R. (2012). "El Consejo de Defensa Suramericano y el proceso de confianza". En Alda, S. y Gómez, V. El concepto y las relaciones multilaterales de seguridad y defensa en el contexto de la UNASUR. Quito: Ministerio de Defensa Nacional del Ecuador.

-Fuchs, R. (2006). "¿Hacia una comunidad regional de seguridad? Las Fuerzas armadas en la percepción de las elites parlamentarias en Argentina, Brasil, Chile, Paraguay y Uruguay". Revista de Ciencia Política, Vol. 26, №2.

-Fuentes, A. (2008). "Comunidad Andina: un proyecto de integración, desarrollo e inserción externa". En Altmann, J. y Rojas, F. América Latina y el Caribe: ¿fragmentación o convergencia? Experiencias recientes de la integración. Quito: FLACSO Ecuador; Ministerio de Cultura del Ecuador; y Fundación Carolina.

-Fuentes, C. (1995). "Política exterior y política de defensa: propuestas para su coordinación". Documento de Trabajo. Santiago de Chile: FLACSO, Area de Relaciones Internacionales y Militares.

-Fuentes, C. (2002). "Resisting change: security-sector reform in Chile". Journal of Conflict, Security \& Development, Año 1, №2.

-Fukuyama, F. (1990). “¿El fin de la Historia?”. Estudios Públicos, № 37. 
-Fukuyama, F. y Matfess, H. (2016). "The March Is Not Linear: Big Party Politics and the Decline of Democracy Worldwide". En Matfess, H. y Miklaucic, M. Beyond convergence. World without order. Washington D.C.: National Defense University.

-Furche, C. (2010). "Política comercial de Chile: 20 años de negociaciones y los próximos desafíos". En Ministerio de Relaciones Exteriores de Chile. El mundo desde el sur. Voces de Chile en Política Exterior. Santiago de Chile: Gobierno de Chile.

-Garay, C. (2003). Las políticas de defensa nacional en el Mercosur y asociados. Historia, procesos, tendencias 1990-2000. Santiago: Universidad de Santiago de Chile.

-García, M. (2011). "Las nuevas alianzas: intereses y oportunidades desde la perspectiva de Brasil". En Wollrad, D.; Maihold, G. y Mols, M. (Eds.). La agenda internacional de América Latina: entre nuevas y viejas alianzas. Buenos Aires: Nueva Sociedad, Fundación Friedrich Ebert.

-Gardini, G. (2011). "Latin American foreign policies between ideology and pragmatism: A framework for analysis". En Gardini, G. y Lambert, P. (Eds.). Latin American foreign policies between ideology and pragmatism. New York: Palgrave Macmillan.

-Gaspar, G. (2003). "Desafíos y dilemas de seguridad en América Latina en la post Guerra Fría". Estudios Internacionales, № 141.

-Giacalone, R. (2014). "UNASUR y la industria de la defensa en Sudamérica". Patria, $\mathrm{N}^{\circ} 2$.

-Gill, B. (2012). "Introduction. International security, armaments and disarmament". En SIPRI Yearbook 2012. Oxford: Oxford University Press.

-Gómez, V. (2012). "América del Sur: una apuesta por la confianza". En Alda, S. y Gómez, V. (Eds.). El concepto y las relaciones multilaterales de seguridad y defensa en el contexto de la UNASUR. Quito: UNED-Ministerio de Defensa Nacional de Ecuador.

-Gonçalves, J. (2013). "Aliança estratégica entre Brasil e Argentina. Antecedentes, estado atual e perspectivas". En Paz, L. (ed.). O CEBRI e as relações internacionais no Brasil. São Paulo: Editora SENAC.

-Grant, C. (2009). “Una voz única para la UE”. Política Exterior. №130.

-Gratuis, S. (2007). "Brasil en las Américas: ¿Una potencia regional pacificadora?”. Documento de Trabajo del FRIDE, N ${ }^{\circ} 35$. 
-Gratius, S. (2008). ¿Hacia una OTAN sudamericana? Brasil y un Consejo de Defensa Sudamericano. Madrid: Fride.

-Gratius, S. (2009). "Las potencias emergentes: ¿estabilizadoras o desestabilizadoras?". En Comentarios de FRIDE. Abril.

-Grebe, H. (2004). "Criterios y mecanismos para la Zona de Paz andina". Disponible en http://www.institutoprisma.org/joomla/images/DocumentosDeTrabajo/RRII/02 crite rios mecanismos zona paz andina.pdf Recuperado en marzo de 2015.

- Griffiths, J. (2006). "La cooperación en el plano de la defensa. Una visión desde la perspectiva de Chile, en el ámbito vecinal". En Kernic, F. y Chuaqui, T. Seguridad y cooperación: aspectos de la seguridad y las relaciones entre la Unión Europea y América Latina. Viena: Schriften der Landesverteidigungsakademie.

-Herz, M. (2010). "Brasil, la seguridad andina, y la política de seguridad regional de los Estados Unidos". En Loveman, B. (ed.). Adictos al fracaso: políticas de seguridad de Estados Unidos en América Latina y la región andina. Santiago de Chile: Lom Ediciones.

-Herz, M. (2011). "Institutional Mechanisms for Conflict Resolution In South America". En Crocker, C.; Hampson, F.; y Aall, P. (eds.). Rewiring Regional Security in a Fragmented World. Washington D.C.: United States Institute of Peace Press.

-Herz, M. (2014). "Seguridad". En Legler, T.; Santa Cruz, A.; y Zamudio, L. Introducción a las Relaciones Internacionales: América Latina y la política global. México: Oxford University Press.

-Hobsbawm, E. (2002). "Guerra y paz en el siglo XXI". En Hobsbawm, E. (2009). Guerra y paz en el siglo XXI. Barcelona: Diario Público.

-Holsti, K. (1996). The State, War and the State of War. Cambridge: Cambridge University Press.

-Huneeus, C. (1990). "La imagen pública de las Fuerzas Armadas en Chile". Sociedad y Fuerzas Armadas. №1.

-Hurrell, A. (1998). "An Emerging Security Community in South America?". En Adler, E. y Barnett, M. (Eds.) Security Communities. Cambridge: Cambridge University Press.

-Jenne, N. y Briones, S. (2018). "Integración regional y la política exterior de Chile ¿paradoja o acomodo?" Estudios Internacionales. N 189. 
-Jobim, N. (2009). "Introducción de Nelson Jobim, Ministro de Defensa de Brasil". En Consejo de Defensa Suramericano. Crónica de su gestación. Santiago de Chile: Gobierno de Chile.

-Justribó, C. (2014) "Ciberdefensa: Una visión desde la UNASUR". Ponencia presentada en el VII Congreso del Instituto de Relaciones Internacionales de la Universidad Nacional de La Plata. La Plata, 26-28 de noviembre de 2014. Disponible

http://www.congresos.unlp.edu.ar/index.php/CRRII/CRRIIVII/paper/view/1849/422

Recuperado en agosto de 2015.

-Kacowicz, A. (2014). "Negociaciones, resolución de conflictos y paz. En Legler, T.; Santa Cruz, A.; y Zamudio, L. Introducción a las Relaciones Internacionales: América Latina y la política global. México: Oxford University Press.

-Keohane, R. y Nye, J. (1988). Poder e Interdependencia. La política mundial en transición. Buenos Aires: GEL.

-Keohane, R. (1993). Instituciones internacionales y poder estatal. Buenos Aires: GEL.

-Klepak, H. (2012). "Some Reflections on the State of Civil-Military Relations in Latin America Today". En Alda, S. y Gómez, V. (Eds.). El concepto y las relaciones multilaterales de seguridad y defensa en el contexto de la UNASUR. Quito: UNEDMinisterio de Defensa Nacional de Ecuador.

-Kupchan, C. (1998). "After Pax Americana". International Security, Vol. 23, № 2.

-Kupchan, C. (2010). How enemies become friends. The sources of stable peace. Princeton and Oxford: Princeton University Press.

-Kupchan, C. (2012). "Why Nobody Will Dominate the Twenty-First Century". Huffington Post. Disponible en http://www.cfr.org/history-and-theory-ofinternational-relations/why-nobody-dominate-twenty-first-century/p27958

Recuperado en junio de 2013.

-Laborie, M. (2011). "La evolución del concepto de seguridad". Documento Marco del IEEE, N ${ }^{\circ} 5$. Disponible http://www.ieee.es/Galerias/fichero/docs marco/2011/DIEEEM052011EvolucionConceptoSeguridad.pdf Recuperado en mayo 2017.

-Larocca, V. (2012). "Defensa y política exterior". En DerGhougassian, K. (coord.), La defensa en el siglo XXI. Argentina y la seguridad regional. Buenos Aires: Capital Intelectual.

-Lechini, G. y Giaccaglia, C. (2007). "El Brasil como Estado intermedio y poder regional: desafíos y oportunidades". El Debate Político, Año 4, № 6/7. 
-Levi, M. (2012). "La experiencia europea como proyecto común de seguridad y defensa, desde la perspectiva latinoamericana". En En Alda, S. y Gómez, V. (Eds.). El concepto y las relaciones multilaterales de seguridad y defensa en el contexto de la UNASUR. Quito: UNED-Ministerio de Defensa Nacional de Ecuador.

-Levitski, S. y Way, L. (2004). "Elecciones sin democracia. El surgimiento del autoritarismo competitivo". Estudios Políticos, N²4.

- Liang, Q. y Xiangsui, W. (2002). Unrestricted Warfare: China's Master Plan to Destroy America. Panamá: Pan American Publishing Company.

-Llenderrosas, E. (2009). "Relaciones Internacionales". En Aznar, L. y De Luca, M. (Coords.). Política. Cuestiones y problemas. Buenos Aires: Emecé Editores.

-Lorenzo, N. (2006). Situación actual y perspectivas del MERCOSUR. Madrid: Fundación CILAE.

-Lorenzini, M. (2013). "Las relaciones argentino-chilenas 2008-2011 ¿Realidad o ficción de la Alianza Estratégica?". Si Somos Americanos. Revista de Estudios Transfronterizos, 13 (1).

-Loveman, B. (1999). For la Patria. Politics and the Armed Forces in Latin America. Wilmington: Scholarly Resources Inc.

-Luiselli, C. (2010). "La integración latinoamericana desde Sudamérica: dos mitos". En Oropeza, A (Coord.). Latinoamérica frente al espejo de su integración 18102010. México: UNAM.

-Magariños, G. (2000). Integración multinacional. Teoría y sistemas. Montevideo: ALADI- Universidad ORT.

-Malamud, A. (2009). "Divergencias en ascenso: viejas y nuevas fracturas en América Latina". Araucaria. Revista Iberoamericana de Filosofía, Política y Humanidades, $\mathrm{N}^{\circ} 21$.

-Malamud, A. (2011). "A leader without followers? The growing divergence between the regional and global performance of brazilian foreign policy". Latin American Politics and Society, Vol. 53, $\mathrm{N}^{\circ} 3$.

-Malamud, C. (2013). "Las Cumbres del ALBA y la nostalgia del esplendor perdido". Disponible en http://www.infolatam.com/2013/08/05/las-cumbres-delalba-y-la-nostalgia-del-esplendor-perdido-2/ Recuperado en julio de 2013.

-Maihold, G. (2011). "Reorientación y diversificación: América Latina entre nuevas oportunidades y viejos legados". En Wollrad, D.; Maihold, G. y Mols, M. (Eds.). La agenda internacional de América Latina: entre nuevas y viejas alianzas. Buenos Aires: Nueva Sociedad, Fundación Friedrich Ebert. 
-Mainwaring, S. y Scully, T. (2009). "América Latina: ocho lecciones de gobernabilidad". Journal of Democracy en Español. Vol. 1.

-Maira, L. (2007). "La política exterior chilena en los años de la Concertación". En Consani, N.; Sepúlveda, A. y; Zeraoui, Z. Transitando los inicios del siglo XXI. Las relaciones internacionales de Argentina, Chile y México. Buenos Aires: Grupo Editor Latinoamericano.

-Mares, D. y Bernstein, S. (1998). "The Use of Force in Latin American Interstate Relations". En Domínguez, J. (ed.). International Security and Democracy: Latin America and the Caribbean in the Post-Cold War Era. Pittsburgh: University of Pittsburgh Press.

-Mares, D. (2012). Latin America and the Illusion of Peace. London: International Institute for Strategic Studies.

-Merke, F. (2012). "Brasil, política exterior y programa nuclear". En DerGhougassian, K. (coord.), La defensa en el siglo XXI. Argentina y la seguridad regional (pp. 119-153). Buenos Aires: Capital Intelectual.

-Montenegro, G. (2012). "El marco doctrinario". En DerGhougassian, K. (coord.), La defensa en el siglo XXI. Argentina y la seguridad regional. Buenos Aires: Capital Intelectual.

-Ministerio de Defensa de Argentina. (1999). Libro Blanco de la Defensa 1999. Buenos Aires: Ministerio de Defensa, Presidencia de la Nación.

-Ministerio de Defensa de Argentina. (2015). Libro Blanco de la Defensa 2015. Buenos Aires: Ministerio de Defensa, Presidencia de la Nación.

-Ministerio de Defensa de España (2010). European Defence Agency: Past, Present \& Future. Madrid: Secretaría General Técnica del Ministerio de Defensa de España.

-Ministerio de Defensa Nacional de Chile. (2009). Consejo de Defensa Suramericano. Crónica de su gestación. Santiago de Chile: Gobierno de Chile.

-Ministerio de Defensa Nacional de Chile. (2010). Libro de la Defensa Nacional de Chile. Santiago de Chile: Gobierno de Chile.

-Ministerio de Defensa Nacional de Ecuador. (2014). "Escuela Suramericana de Defensa: aportando a la identidad y al pensamiento estratégico". Patria, Nㅜ 3 .

-Ministerio de Relaciones Exteriores de Chile. (2008). Principios y Prioridades de la Política Exterior de Chile. Santiago, Chile: Gobierno de Chile. 
-Ministerio de Relaciones Exteriores de Chile. (2010). Perspectivas, proyecciones y desafíos de la política exterior de Chile. Santiago: Gobierno de Chile.

-Ministerio de Relaciones Exteriores de Chile. (2018). Política exterior de Chile 2030. Santiago: Gobierno de Chile.

-Molina, C. (2000). Cooperación regional: potencialidades y limitaciones desde la perspectiva de la defensa nacional. Fuerzas Armadas y Sociedad, №15.

-Morandé, J. (2007). "Política exterior de Chile y Argentina: dos opciones contemporáneas de inserción regional". En Artaza, M. y Milet, P. Nuestros vecinos. Santiago de Chile: RIL Editores.

-Moreira, A. (2008). Consejo Sudamericano de Defensa: Hacia una integración regional en defensa. Buenos Aires: RESDAL.

-Naím, M. (2009). "Minilateralism: The Magic Number to Get Real International Action". Foreign Policy. N¹73. Disponible en http://foreignpolicy.com/2009/06/21/minilateralism/ Recuperado en enero 2017.

-Naím, M. (2013). El fin del poder. Buenos Aires: Debate.

-Nolte, D. (2007). "Potencias regionales: conceptos y enfoques de análisis". El Debate Político. Revista Iberoamericana de Análisis Político. Año 4, №6/7.

-Nye, J. (2005). Soft Power: The Means to Success in World Politics. New York: Public Affairs.

-Nye, J. (2011). The future of power. New York: Public Affairs.

-O’Donnell, G. (2004). "Accountability horizontal: la institucionalización legal de la desconfianza política”. Revista Española de Ciencia Política, Nº 11.

-Orchard, P. (2012). "The evolution of the responsibility to Project: at a crossroads?" International Affairs, Vol. 88, №2.

-Ortega, R. (2010). Escenario y Estrategia. Santiago de Chile: Academia de Guerra del Ejército de Chile.

-Palma, H. (2012). "La cooperación fronteriza en el Área Andina". En En Alda, S. y Gómez, V. (Eds.). El concepto y las relaciones multilaterales de seguridad y defensa en el contexto de la UNASUR. Quito: UNED-Ministerio de Defensa Nacional de Ecuador.

-Peña, F. (2008) “Relaçoes Brasil/Argentina”. Política Externa. Vol. 16, № 4. 
-Peñaranda, J. (2012). "La Unión Europea y su proyecto común de la defensa". En Alda, S. y Gómez, V. (Eds.). El concepto y las relaciones multilaterales de seguridad y defensa en el contexto de la UNASUR. Quito: UNED-Ministerio de Defensa Nacional de Ecuador.

-Pérez-Liñán, A. (2009). Juicio político al presidente y nueva inestabilidad política en América Latina. Buenos Aires: Fondo de Cultura Económica.

-Perrotta, D. (2013). "La Integración regional como objeto de estudio. De las teorías tradicionales a los enfoques actuales", en Llanderrozas, L. (ed.). Relaciones Internacionales. Teorías y Debates. Buenos Aires: EUDEBA.

-Pey, C. y Riquelme, J. (2007). "Algunos alcances políticos y jurídicos del MERCOSUR desde una perspectiva chilena". Revista Austral de Ciencias Sociales, $\mathrm{N}^{\circ} 13$.

-Pinheiro, S. (2007). "El mundo multipolar y la integración sudamericana". Res Diplomatica. Segunda época, $N^{\circ} 1$.

-Pinheiro, S. (2012). "The future of MERCOSUR". Austral: Brazilian Journal of Strategy \& International Relations, Vol. 1, №1.

-Planas, R. (2010). "UNASUR finds a role in conflict mediation". World Politics Review. Octubre. Disponible en http://www.worldpoliticsreview.com/articles/6623/unasur-finds-a-role-in-conflictmediation Recuperado en abril de 2013.

-PNUD. (2013). Informe sobre Desarrollo Humano 2013. El ascenso del Sur: Progreso humano en un mundo diverso. Nueva York: PNUD.

-Portales, C. (2011). "Desafíos para la política exterior en las próximas décadas: Chile y la región en un mundo global". Estudios Internacionales, N 169.

-Puricelli, A. (2012). "Prólogo". En DerGhougassian, K. (coord.), La defensa en el siglo XXI. Argentina y la seguridad regional. Buenos Aires: Capital Intelectual.

-Quezada, A. (2016). Chile y Ecuador, un caso de relaciones paravecinales. Quito: Universidad Andina Simón Bolívar.

-Raggio, B. (2012). "Balance sistema seguridad hemisférico". En Alda, S. y Gómez, V. (Eds.). El concepto y las relaciones multilaterales de seguridad y defensa en el contexto de la UNASUR. Quito: UNED-Ministerio de Defensa Nacional de Ecuador.

-Resende-Santos, J. (2007). Neorealism, States and the Modern Mass Army. Nueva York: Cambridge University Press. 
-Rial, J. (2012). "Nuevos escenarios para las fuerzas militares en América Latina". En Atlas Comparativo de la Defensa en América Latina y Caribe. Buenos Aires: RESDAL-SER.

-Riquelme, J. (2013). "La relación entre integración y seguridad en el MERCOSUR y sus proyecciones hacia Sudamérica". Revista de Relaciones Internacionales, Estrategia y Seguridad. Vol. 8, №1.

-Riquelme, J. (2014). "Nuevos horizontes del multilateralismo global: el desarrollo de la Responsabilidad de Proteger y la perspectiva de Chile". Relaciones Internacionales, $\mathrm{N}^{\circ} 46$.

-Riquelme, J. y Rivera, D. (2014). “¿Hacia dónde se dirige el Consejo de Defensa Suramericano?”. Disponible en http://lideresinternacionales.com/articulo/consejosudamericano.html Recuperado en junio de 2015.

-Riquelme ,J. y Rosso, J. (2014). "Desafíos y oportunidades de la vinculación entre la política exterior y la política de defensa de Chile". En Jimenez, D. y Matus, M. Transformaciones en el ámbito de la seguridad y defensa: una visión en el vigésimo aniversario del CESIM. Santiago de Chile: CESIM.

-Riquelme, J. (2016). "El Consejo de Defensa Suramericano y la autonomía estratégica regional". Ensayos Militares, Vol. 2, №1.

-Rivera, F. (2009). "Introducción de Fredy Rivera Vélez, Viceministro de Gobierno de Ecuador". En Consejo de Defensa Suramericano. Crónica de su gestación. Santiago de Chile: Gobierno de Chile.

-Rizzo de Oliveira, E. (2009). "A Estrategia Nacional de Defesa e a reorganização e transformação das forças armadas”. Interesse Nacional. Abril-junio.

-Robledo, M. y Rojas, F. (2002). "Construyendo un régimen cooperativo de seguridad en el Cono Sur de América Latina. Elementos conceptuales, políticos y estratégicos". Fuerzas Armadas y Sociedad. Año 17, №1-2.

-Rodrigues, G. (2012). "La Responsabilidad al Proteger: Motivaciones, contenidos y cambios". Pensamiento Propio, N³5.

-Rojas, F. (2002). "Espacios para el diálogo. El fin de la guerra fría y la solución de conflictos en el Cono Sur". Desarrollo y Cooperación, № 5. Disponible en http.www.seguridadregional-fes.org/upload/3080-001 g.pdf:> Revisado en mayo de 2007

-Rojas, F. (2012). "Contexto internacional y alternativas bilaterales y multilaterales de la cooperación en defensa en América Latina”. En Alda, S. y Gómez, V. (Eds.). El concepto y las relaciones multilaterales de seguridad y defensa en el contexto de la UNASUR. Quito: UNED-Ministerio de Defensa Nacional de Ecuador. 
-Rojas, F. (2014). "Regionalismo e Integración Regional", en Legler, T., Santa Cruz, A. y Zamudio, L. (eds.) Introducción a las Relaciones Internacionales: América Latina y la Política Global. México: Oxford University Press.

-Rosenthal, G. (1993). "Treinta años de integración en América Latina: un examen crítico". Estudios Internacionales, № 101.

-Rouquié, A. (2011). "América Latina 2010: geopolítica y ambiciones internacionales". En Wollrad, D.; Maihold, G. y Mols, M. (Eds.). La agenda internacional de América Latina: entre nuevas y viejas alianzas. Buenos Aires: Nueva Sociedad, Fundación Friedrich Ebert.

-Russell, R. (2011). "América Latina; ¿entre la integración y la polarización? Un falso dilema". En Wollrad, D.; Maihold, G. y Mols, M. (Eds.). La agenda internacional de América Latina: entre nuevas y viejas alianzas. Buenos Aires: Nueva Sociedad, Fundación Friedrich Ebert.

-Salgado, R. (2016). "Responsibility to Protect as a Norm under Construction: The Divergent Views from the South". LASAforum, XLVII, 2.

-Sanahuja, J. (2008). "Del regionalismo abierto al regionalismo posliberal. Crisis y cambio en la integración en América Latina y el Caribe", en Martínez, L. et. al. (eds.). Anuario de la integración regional de la América Latina y el Gran Caribe 2008-2009. Buenos Aires: CRIES.

-Sanahuja, J. y Verdes-Montenegro, F. (2014). "Seguridad y defensa en Suramérica: regionalismo, cooperación y autonomía en el marco de UNASUR". Anuario de Integración 10. Buenos Aires: CRIES.

-Saint-Pierre, H. (2012). "La construcción de la defensa en el Brasil contemporáneo". En Alda, S. y Saint-Pierre, H. (Coords.). Gobernabilidad y democracia. Defensa y transiciones de Brasil y España. Santiago de Chile: RIL Editores.

-Saint-Pierre, H. y Zague, J. (2014). "La industria de la defensa y la autonomía estratégica: el caso de Brasil”. Patria, № 2.

-Sepúlveda, B. (1995). "No intervención y derecho de injerencia: el imperio o la decadencia de la soberanía". En Seara, M. Las Naciones Unidas a los cincuenta años. México: FCE.

-Silva, M. (2011). "La Alianza Bolivariana para las Américas (ALBA): Aspectos de seguridad y defensa y elementos de participación social". En Serbin, A. (Coord.), De la ONU al ALBA: Prevención de conflictos y espacios de participación ciudadana. Buenos Aires: Ediciones CRIES. 
-Simonoff, A. (2013). "Una visión estructural de la política exterior argentina y el rol de Chile desde el proceso de democratización de 1983". Si Somos Americanos, Vol. XIII, N¹.

-SIPRI (2017). SIPRI Yearbook 2017. Oxford: Oxford University Press. Disponible en https://www.sipri.org/sites/default/files/2017-10/yb17 summary esp 0.pdf Recuperado en noviembre de 2017.

-Smith, R. (2006). "Entrevista al general Sir Rupert Smith". International Review of the Red Cross, N864.

-Soares de Lima, M. y Hirst, M. (2007). "El Brasil como Estado intermedio y poder regional: desafíos y oportunidades". El Debate Político. Revista Iberoamericana de Análisis Político. Año 4, Nº 6/7

-Sodupe, K. (2004). La teoría de las Relaciones Internacionales a comienzos del siglo XXI. Bilbao: Universidad del País Vasco.

-Terradas, N. (2009). El misterio de la Larga Paz Sudamericana: Revisión de un "nuevo" viejo debate. Jornadas de Relaciones Internacionales 2009. FLACSO Argentina. Disponible en http://rrii.flacso.org.ar/web/wpcontent/uploads/2010/09/terradas nicolas.pdf Recuperado en julio de 2013.

-Themnér, L. y Wallensteen, P. (2012). "Patterns of organized violence, 2001-10". En SIPRI Yearbook 2012. Oxford: Oxford University Press.

-Tokatlián, J. y Russell, R. (2003). "De la autonomía periférica a la autonomía relacional: una mirada teórica desde el Cono Sur". Perfiles Latinoamericanos, $\mathrm{N}^{\circ}$ 21.

-Tokatlián, J. (2011). "Latinoamérica y sus alianzas extrarregionales: entre el espejismo, la ilusión y la evidencia". En Wollrad, D.; Maihold, G. y Mols, M. (Eds.). La agenda internacional de América Latina: entre nuevas y viejas alianzas. Buenos Aires: Nueva Sociedad, Fundación Friedrich Ebert.

-Tokatlián, J. (2012). "El entorno global". En DerGhougassian, K. (comp.). La defensa en el siglo XXI. Argentina y la seguridad regional. Buenos Aires: Capital Intelectual.

-Tulchin, J. y Espach, R. (2004). "América Latina en el nuevo sistema internacional: la necesidad del pensamiento estratégico". En Tulchin, J. y Espach, R. (eds.). América Latina en el nuevo sistema internacional. Barcelona: Bellaterra.

-Vacas, F. y Rodríguez, J. (2013). La dimensión exterior de UNASUR: instrumento de la acción concertada de los Estados sudamericanos. Madrid: CEIB.

-Van Klaveren, A. (2014). "El análisis de la política exterior: Una visión desde América Latina”. En Legler, T., Santa Cruz, A. y Zamudio, L. (eds.) Introducción a 
las Relaciones Internacionales: América Latina y la Política Global. México: Oxford University Press.

-Vilas, C. (2004). “¿Populismos reciclados o neoliberalismo a secas? El mito del neopopulismo latinoamericano". Revista de Sociologia e Política, N22.

-Villagómez, P. (2014). "Sobre los argumentos que fundamentan la denuncia del Tratado Interamericano de Asistencia Recíproca (TIAR)". Patria, № 2.

-Vitelli, M. (2013). "Teoría y práctica de las identidades colectivas en las Relaciones Internacionales. El caso del Consejo de Defensa Sudamericano". Reflexión Política, Vol. 15, №30.

-Wellington, C. (2012). "Gasto militar en UNASUR". En Alda, S. y Gómez, V. (Eds.). El concepto y las relaciones multilaterales de seguridad y defensa en el contexto de la UNASUR. Quito: UNED-Ministerio de Defensa Nacional de Ecuador.

-Wendt, A. (1992). Anarchy is what States make of it: The social construction of power politics". International Organization, Vol. 46, №2.

-Williams, P. (2016). "The global crisis of governance". En Matfess, H. y Miklaucic, M. Beyond convergence. World without order. Washington D.C.: National Defense University.

-Wilhelmy, M. (1988). Política Internacional: enfoques y realidades. Buenos Aires: GEL.

-Witker, I. (2005). "La política exterior de Chile frente a la teoría de las Relaciones Internacionales. 1990-1999". Bicentenario. Revista de Historia de Chile y América, Vol. 4, $\mathrm{N}^{\circ} 1$.

-Witker, I. (2012). "El multilateralismo beligerante en la región". En Soto, A. y Matus, M (Comp.). América Latina. Tendencias y perspectivas del nuevo siglo. Santiago de Chile: CESIM.

-Yarger, H (2006). Strategic Theory for the 21st Century: The Little Book On Big Strategy. Carlisle Barracks, PA: U.S. Army War College.

-Young, O. (1997). "Global governance: Toward a theory of descentralized world order". En Young, O. (ed.). Global governance. Drawing insights from the environmental experience. London: The MIT Press.

-Zovatto, D. (2016). "Soplan vientos de cambio en América del Sur". Columna de opinión en diario La Nación, 26 febrero 2016. Disponible en http://www.nacion.com/opinion/foros/Soplan-vientos-cambio-America-

Sur 0 1545045483.html Recuperado en febrero de 2016. 